UNIVERSIDADE DE SÃO PAULO

ESCOLA DE ARTES, CIÊNCIAS E HUMANIDADES

PROGRAMA DE PÓS-GRADUAÇÃO EM ESTUDOS CULTURAIS

CARLOS CÉSAR LEONARDI

A construção da represa Guarapiranga: imagem, técnica e paisagem

São Paulo

2018 


\section{A construção da represa Guarapiranga: imagem, técnica e paisagem}

Versão corrigida

Dissertação apresentada à Escola de Artes, Ciências e Humanidades da Universidade de São Paulo para obtenção do título de Mestre em Filosofia pelo Programa de Pós-Graduação em Estudos Culturais.

Versão corrigida contendo as alterações solicitadas pela comissão julgadora em 19/09/2018. A versão original encontra-se em acervo reservado na Biblioteca da EACH/USP e na Biblioteca Digital de Teses e Dissertações da USP (BDTD), de acordo com a Resolução CoPGr 6018, de 13 de outubro de 2011.

Área de concentração:

Estudos Culturais

Orientador:

Prof. Livre Docente Rogério Monteiro de Siqueira

São Paulo 
Autorizo a reprodução e divulgação total ou parcial deste trabalho, por qualquer meio convencional ou eletrônico, para fins de estudo e pesquisa, desde que citada a fonte.

Leonardi. Carlos César

A construção da represa Guarapiranga: imagem, técnica e paisagem / Carlos César Leonardi ; orientador, Rogério Monteiro de Siqueira. - 2018

196 f. : il.

Dissertação (Mestrado em Filosofia) - Programa de PósGraduação em Estudos Culturais, Escola de Artes, Ciências e Humanidades, Universidade de São Paulo, São Paulo.

Versão corrigida

1. Paisagem urbana - São Paulo. 2. Represas - São Paulo. 3. Represa Guarapiranga - Construção; História. 4. São Paulo Tramway, Light and Power Company Ltda . I. Siqueira, Rogério Monteiro de, orient. II. Título

CDD 22.ed.- 307.76 
LEONARDI, Carlos César

A construção da represa Guarapiranga: imagem, técnica e paisagem

Dissertação apresentada à Escola de Artes, Ciências e Humanidades da Universidade de São Paulo para obtenção do título de Mestre em Filosofia do Programa de Pós-Graduação em Estudos Culturais.

Área de concentração:

Estudos Culturais

Aprovado em: 19/09/2018

\section{Banca Examinadora}

Prof. Dr. Janes Jorge

Instituição: Universidade Federal de São Paulo

Profa. Dra. Cristina de Campos

Instituição: Universidade Estadual de Campinas

Profa. Dra. Sílvia Helena Zanirato

Instituição: Universidade de São Paulo 
"[...] as imagens, assim como as palavras são a matéria de que somos feitos" (MANGUEL, 2006, p. 21). 


\section{RESUMO}

LEONARDI, Carlos César. A construção da represa Guarapiranga: imagem, técnica e paisagem. 2018. 196 p. Dissertação (Mestrado em Filosofia) - Escola de Artes, Ciências e Humanidades da Universidade de São Paulo, São Paulo, 2018. Versão corrigida.

O trabalho visa por meio de um conjunto de imagens fotográficas da Fundação Energia e Saneamento e de outras fontes correlatas do período analisar historicamente a construção da represa Guarapiranga (1906-1909) em Santo Amaro, ao sul da cidade de São Paulo, bem como discutir as alterações da paisagem e as técnicas de engenharia envolvidas no processo. Tratava-se de um empreendimento da canadense The São Paulo Tramway, Light and Power Company Ltd., companhia de força e luz a se instalar no Brasil, em 1899. Para tanto, apresenta-se também a história da ocupação do Estado e as demandas de água e energia na região, sobretudo em fins do XIX e começo do XX.

Palavras-chave: Represa Guarapiranga. Companhia Light. Fotografia. Paisagem. Técnica. 


\begin{abstract}
LEONARDI, Carlos César. The construction of the Guarapiranga dam: image, technique and landscape. 2018. 196 p. Dissertation (Master in Philosophy) - School of Arts, Sciences and Humanities, University of São Paulo, São Paulo, 2018. Corrected version.

The work aims at historically analyzing the construction of the Guarapiranga dam (1906-1909) in Santo Amaro, south of the city of São Paulo, through a series of photographic images of the Energy and Sanitation Foundation and other related sources. Besides, it intends to discuss the landscape changes promoted by and the engineering techniques employed in the process. It was an enterprise of the Canadian The São Paulo Tramway, Light and Power Company Ltd., company of force and light to be installed in Brazil, in 1899. For this, we also present the history of the State occupation and the demands of water and energy in the region, especially in the late nineteenth and early twentieth centuries.
\end{abstract}

Keywords: Guarapiranga Dam. Company Light. Photography. Landscape. Technique. 


\section{LISTA DE FIGURAS}

Figura 1 - Mapa da Bacia hidrográfica do rio Tietê na região de São Paulo, c.a. 1900 .

Figura 2 - Representação espacial da cultura cafeeira e as estradas de ferro no Estado de São Paulo, início do século XX

Figura 3 - Gráfico da produção e preço do café, de 1880 a 1912.

Figura 4 - Mapa da divisão político-administrativa do Estado de São Paulo em 1800

Figura 5 - Mapa da divisão político-administrativa do Estado de São Paulo em 1900

Figura 6 - As ferrovias na regionalização de São Paulo

Figura 7 - Figura 9 - O desenvolvimento da mancha urbana da cidade de São Paulo, até metade do século XX

Figura 8 - Cópia fotográfica. Trem a vapor da Cia. Carris de Ferro de São Paulo, na estação do Encontro, ligando São Paulo a Santo Amaro, 1910.

Figura 9 - Cópia fotográfica. Locomotiva elétrica construída na oficina da Light, carro $n^{\circ} 182,1910$

Figura 10 - Estação de Santo Amaro para cargas e passageiros na entrada da Vila, 1916

Figura 11 - Cópia fotográfica. Obras do conduto forçado, entre os reservatórios na unidade de Parnaíba, em trecho sobre antigo leito do rio Tietê (Santana de Parnaíba), 22.08.1900

Figura 12 - Mapa da localização da bacia hidrográfica que forma a represa de Santo Amaro (atual Guarapiranga).

Figura 13 - Cópias fotográficas comparativas das construções da Light em Santana de Parnaíba (1900) e Santo Amaro (1906)

Figura 14 - Cópia fotográfica. Construção da represa de Santo Amaro (Guarapiranga).

Reforço de concreto dos túneis de desvio, 1906

Figura 15 - Cópia fotográfica. Construção da represa de Santo Amaro (Guarapiranga). Grupo de trabalhadores com bovinos, 1906

Figura 16 - Composição de cópias fotográficas das construções da Light

(Guarapiranga), 1906, com destaque para a chancela do fotógrafo B. Klofs 
Figura 17 - Frontispício dos relatórios encadernados da Light para os anos de 1906, 1907 e 1908

Figura 18 - Cópia de blueprint e cópia fotográfica da construção da nova grade de proteção da represa de Santo Amaro (Guarapiranga), 1909

Figura 19 - Cópia fotográfica. Composição de imagens da construção da represa Guarapiranga, 1906 e1909....

Figura 20 - Cópia de blueprint do reservatório de armazenamento de águas. Represa de Santo Amaro (atual represa de Guarapiranga), 1908.

Figura 21 - Mapa da vegetação original da cidade de São Paulo e vizinhanças, conforme classificação de Kurt Hueck. Destaque para a represa Guarapiranga

Figura 22 - Cópia fotográfica. Ponte Guarapiranga, 1906

Figura 23 - Cópia fotográfica. Construção da represa de Santo Amaro (atual Guarapiranga). Local da barragem a leste da estrada, 1906

Figura 24 - Cópia Fotográfica. Tereno da represa Santo Amaro (Guarapiranga) a oeste do rio [Guarapiranga] depois de completada a limpeza da área, 1906......133

Figura 25 - Cópia fotográfica. Construção de represa e vista do rio Guarapiranga, 1908

Figura 26- Cópia fotográfica. Construção da represa de Santo Amaro (atual Guarapiranga). Inclinação externa da barragem vista do extremo oeste, 1909

Figura 27 - Cópia fotográfica. Construção da represa de Santo Amaro (Guarapiranga).

Vista geral da barragem e reservatório. c.a. 1909

Figura 28 - Composição de cópias fotográficas. O rio, o homem, a técnica e a represa. Imagens de 1906 a 1909.

Figura 29 - Cópia fotográfica. Construção da represa de Santo Amaro, (atual Guarapiranga), 1907

Figura 30 - Cópia fotográfica. Construção da represa de Santo Amaro e vista do rio Guarapiranga, 1907

Figura 31 - Desenho técnico das dimensões transversais do talude da barragem da Represa do rio Guarapiranga, 1908

Figura 32 - Cópia fotográfica. Construção da represa de Santo Amaro (Guarapiranga). 
Figura 33 - Cópia fotográfica. Construção da represa de Santo Amaro (Guarapiranga).

Vista geral da plataforma de reforço da barragem, 1907

Figura 34 - Cópia fotográfica. Construção da represa de Santo Amaro (Guarapiranga). Vista geral do local de retirada de aterro mostrando os níveis baixo, intermediário e alto, 1907.

Figura 35 - Cópia fotográfica. Construção da represa de Santo Amaro (Guarapiranga). Vista geral do local de retirada de aterro mostrando os níveis baixo, intermediário e alto, 1907.

Figura 36 - Cópia fotográfica. Demolição do Morro do Castelo, Rio de Janeiro, 1921

Figura 37 - Cópia fotográfica. Demolição do Morro do Castelo, Rio de Janeiro, 1922

Figura 38 - Composição de cópias fotográficas. Desmonte hidráulico em Guarapiranga (1907) e no Morro do Castelo (1921)..... 161

Figura 39 - Fim do trabalho nos túneis de concreto no Rio Guarapiranga, 1906

Figura 40 - Cópia fotográfica. Construção da represa de Santo Amaro

(Guarapiranga). Abertura provocada por vazamento na fundação na barragem, 1908

Figura 41 - Cópia fotográfica. Construção da represa de Santo Amaro (Guarapiranga).

Construção de caixa de contenção para sanar o vazamento, 1908

Figura 42 - Cópias fotográficas. Construção da represa de Santo Amaro

(Guarapiranga). Vazamento na fundação, 1908

Figura 43 - Composição de cópias fotográficas. Construção da represa Guarapiranga, 1907

Figura 44 - Desenho técnico. Demonstração de princípio para servir de base à resolução de problema do empuxo de terras nas represas

Figura 45 - Planta geral do aproveitamento hidroelétrico da Light nas mediações da cidade de São Paulo. c.d. 1940

Figura 46 - Detalhe da Planta geral do aproveitamento hidroelétrico da Light no trajeto Represa Guarapiranga - Santana de Parnaíba. c.d. 1940

Figura 47 - Cópia fotográfica. Construção da represa de Santo Amaro (Guarapiranga). Vista panorâmica da barragem, 1908

Figura 48 - Cópia fotográfica. Construção da represa de Santo Amaro (Guarapiranga), 1907 


\section{LISTA DE TABELAS}

Tabela 1 - A evolução populacional, ferroviária e o café no Estado de São Paulo, de 1860 a 1920

Tabela 2 - Consumo de energia elétrica na cidade de São Paulo fornecida pela The São Paulo Tramway, Light and Power Co. Ltd. 


\section{LISTA DE SIGLAS}

FES Fundação Energia e Saneamento

SEADE Fundação Sistema Estadual de Análise de Dados 


\section{SUMÁRIO}

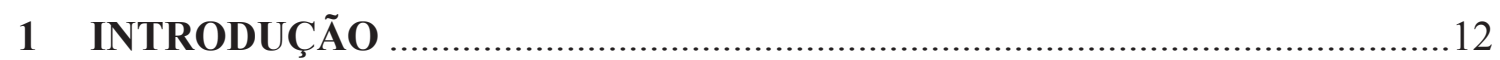

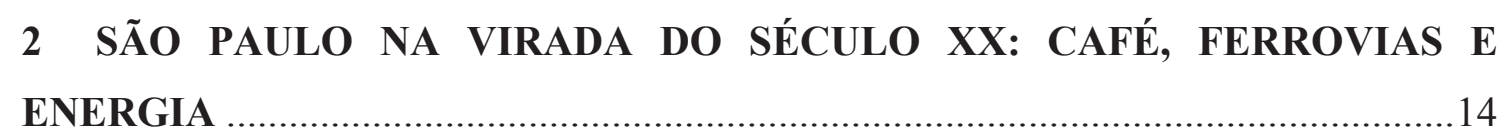

2.1 A represa de Guarapiranga: considerações do sítio físico .......................................14

2.2 Café e ferrovia: o início das grandes alterações da paisagem .................................22

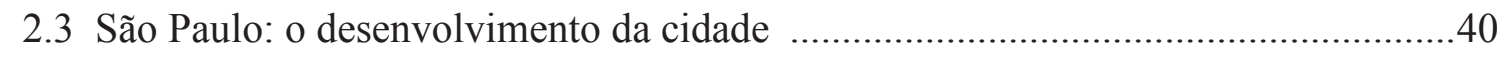

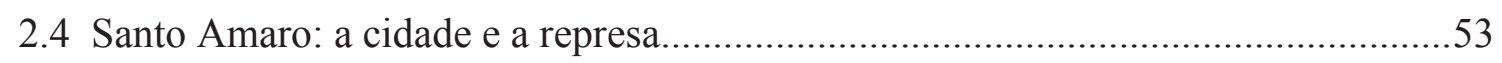

2.5 A constituição da Light e sua atuação na Guarapiranga ..........................................68

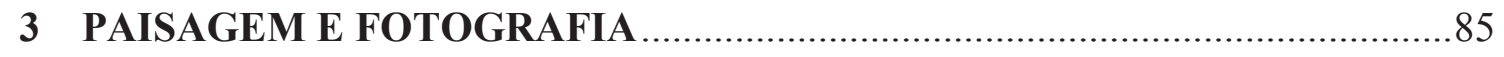

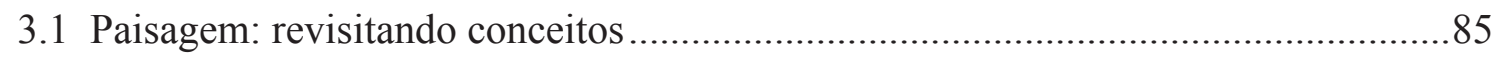

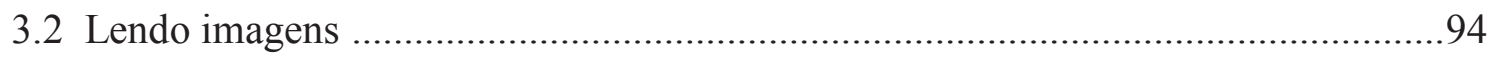

3.3 Paisagens nas fotografias da construção da represa Guarapiranga......................... 102

4 A LIGHT: ACERVO, TÉCNICAS E REGISTRO ......................................... 111

4.1 O acervo fotográfico da Light e seus relatórios .................................................111

4.2 Análise do corpus: o rio, o homem, a técnica e a represa ...................................123

4.3 Fotografia e tecnologia na construção da represa Guarapiranga .............................144

$4.4 \mathrm{O}$ desmonte hidráulico na construção da represa ................................................. 146

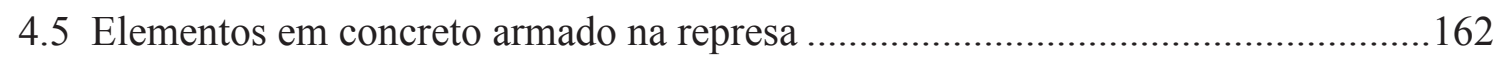

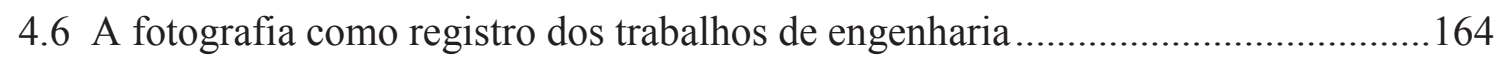

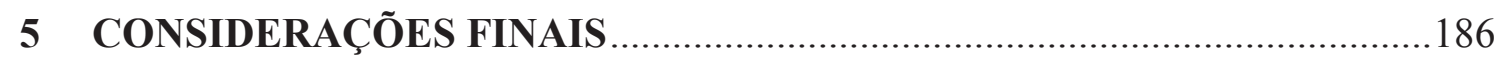

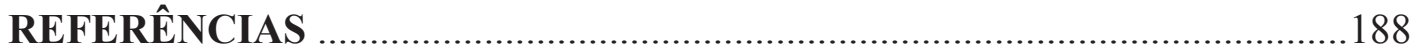




\section{1 - INTRODUÇÃO}

Entre os anos de 1906 e 1909, no então município de Santo Amaro, ao sul do município de São Paulo, foi construída uma grande represa cujo intuito era armazenar água para a movimentação de turbinas localizadas à jusante, em Parnaíba (atual Santana de Parnaíba/SP) e a produção de energia elétrica para as diversas atividades econômicas da Capital paulista. A essa represa, quando do início da sua construção e finalização das obras, deu-se o nome de Santo Amaro, posteriormente Guarapiranga, em virtude do mesmo nome do rio principal represado para a sua formação.

Um conjunto de imagens fotográficas da construção da represa foi produzido pela canadense The São Paulo Tramway, Light and Power Company Ltd., a companhia de força e luz que se instalou no Brasil, em 1899, responsável pelo empreendimento. Essas fotografias pertencem atualmente ao acervo da Fundação Energia e Saneamento FES e serão o principal objeto deste estudo.

Embora pouco material historiográfico redigido tenha sido encontrado sobre a construção da represa Guarapiranga, exceção composta principalmente pelos trabalhos de Jorge (2015) e Sávio (2005), procurou-se cotejá-los às imagens de maneira a empreender um discurso das questões analisadas e compor um quadro mais efetivo da história de São Paulo conjugada ao da represa na região que tanto se alterou.

No início do trabalho descrevemos a localização geográfica da represa Guarapiranga e os compartimentos geomorfológicos do Estado de São Paulo, salientando as bacias hidrográficas e a sua atuação física na formação do relevo. A represa está localizada na bacia hidrográfica do Alto Tietê, a mesma onde se encontra a usina hidrelétrica de Parnaíba e que motivou o represamento do Guarapiranga à montante, a fim de se ter o controle das águas e a produção de energia elétrica pela Light.

Para contextualizar a construção da represa no período abordamos o processo econômico e político no qual estava inserido o País e São Paulo, grande produtor e exportador mundial de café à época. No Brasil, também estava ocorrendo a mudança da mão de obra escrava para a assalariada, a massiva imigração europeia, uma nova forma de governo com a elite agrária cafeicultora assumindo o poder, o cientificismo como maneira de atuar no mundo e a formação de grandes companhias capitalistas para 
explorar os meios de transporte e a produção energética por meio de hidrelétricas, muito mais eficientes do ponto de vista econômico e de produção.

Nesse contexto, a construção da represa Guarapiranga facilitava a assimilação de Santo Amaro à Capital, implementava a iluminação pública e a disseminação das linhas de bondes elétricos da Light. Em São Paulo, uma nova ordem social incorporava as transformações tecnológicas na lógica capitalista da produção do espaço, onde muitos aspectos físicos, aliados sobremaneira à ação humana, reconfiguraram a paisagem geográfica, por meio dos chamados melhoramentos urbanos, com seus traçados de linhas férreas, o loteamento e ocupação territorial, o aumento no fluxo de capitais e de pessoas. Aos poucos a lenha era substituída pela energia elétrica e a industrialização ia se firmando com a Light desbancando diversas outras companhias e incorporando-as às suas atividades.

Na segunda parte do trabalho, apresentamos um longo balanço sobre o conceito de paisagem e suas ramificações para, depois, investigar as modificações pelas quais passou a região de Santo Amaro por conta da construção da Represa. Este deu-se a partir das imagens fotográficas e de outras narrativas discursivas, cartográficas e documentais que trazem a compreensão e a historicidade do processo de transformação de um lugar.

Posteriormente adentramos mais especificamente na formação e na importância do acervo da FES para a realização da pesquisa, do qual obtivemos um conjunto expressivo de imagens fotográficas do seu arquivo, bastante relevantes para a compreensão da construção da represa Guarapiranga. Por fim, discorremos sobre as técnicas empregadas na construção da represa, registrada pelas imagens fotográficas do desmonte hidráulico e as comparando com imagens de outra região em anos posteriores onde se registrou o emprego da mesma técnica.

Com isso procura-se descrever a história de uma região inscrita em um espaço e tempo, a qual, por meio das técnicas inseridas em um contexto econômico amplo, possibilitou a construção da Guarapiranga e o seu registro fotográfico na transformação da paisagem. 


\section{2 - SÃO PAULO NA VIRADA DO SÉCULO XX: CAFÉ, FERROVIAS E}

\section{ENERGIA}

\section{1 - A Represa de Guarapiranga: considerações do sítio físico}

Para melhor dimensionar a compreensão do processo da construção da represa Guarapiranga (1906 - 1909) e consequentemente o processo social de urbanização no qual está inserida, abordaremos inicialmente a sua localização no sítio em que está assentada.

Os elementos naturais mais relevantes para a formação do espaço físico são os geomorfológicos e os hidrográficos, com a observação de que o processo de urbanização não é determinado pelo sítio natural, mas, neste caso da construção da represa Guarapiranga, foi preponderante a escolha do local.

O principal rio da cidade de São Paulo e seu entorno é o Tietê que possui uma extensão de aproximadamente 1.100 quilômetros, da nascente na Serra do Mar (no atual município de Salesópolis, a uma altitude próxima de 1.030 metros) até a sua foz no rio Paraná. Desenvolve um trajeto sudeste-noroeste e atravessa praticamente todo o Estado. Embora as águas de sua nascente encontram-se a 22 quilômetros do oceano Atlântico, a sua localização na vertente da Serra oposta ao oceano, e o relevo, fizeram com que o rio seguisse para o interior, sendo assim muito utilizado para acessar as antigas vilas que se encontravam ao seu redor e para explorar novos territórios, servindo como via de penetração natural pelos pioneiros plantadores de café, que desciam o rio e iniciavam a cafeicultura, em fins do século XIX (MONBEIG, 1984) e muito antes, ainda, era utilizado como via fluvial na rota das monções, sendo, conforme Matos (1990, p. 30), o único caso no Brasil meridional de utilização frequente e a longa distância, que partia geralmente de Porto Feliz (primitivamente Araritaguaba) onde o rio era melhor navegável, e após as quedas nas proximidades da atual Santana de Parnaíba, desempenhando seu grande papel de via de penetração interiorana.

O rio ao penetrar na cidade de São Paulo, localizada geomorfologicamente em uma Bacia Sedimentar de idade cenozóica ${ }^{1}$, formava uma larga e extensa planície

\footnotetext{
1 Área rebaixada, em relação ao relevo do entorno e de idade geológica recente (Era Cenozóica: aproximadamente há 65 milhões de anos até o presente - Dicionário de Ecologia e Ciências Ambientais. $2^{\mathrm{a}}$ ed., São Paulo: UNESP; Melhoramentos, 2001, p. 87).
} 
aluvial, dentro da qual descrevia inúmeros meandros que apresentavam a largura de 25 a 50 metros e uma profundidade média de 2 a 3 metros, o que variava de acordo com a época de cheia ou vazante, com seu vale assimétrico e limitado ao norte pela Serra da Cantareira e seus contrafortes e ao sul pelas colinas sedimentares sobre as quais está assentada a maior parte da Capital paulista e Santo Amaro (SANTOS, 1958, p. 48).

A bacia hidrográfica do rio Tietê, na região de São Paulo, possui uma drenagem dentrítica, assemelhando-se a raiz de uma árvore, sem uma orientação definida das nascentes dos rios, como notado na representação cartográfica (Figura 1), onde observamos a pequena extensão dos rios na sua margem direita, ao norte, em contraposição às grandes extensões dos afluentes da margem esquerda, ao sul do rio Tietê, com destaque para os dois rios principais: Tamanduateí e Pinheiros. O rio Guarapiranga (primeiramente denominado M'boy-Guassu) é o principal formador da represa de mesmo nome e um afluente do rio Pinheiros, em sua margem esquerda, a oeste. Neste mapa observa-se o rio Guarapiranga anterior à formação da represa, sendo um dos raros mapas que obtivemos com tal representação. 
Figura 1 - Bacia hidrográfica do rio Tietê na região de São Paulo, c.a. 1900

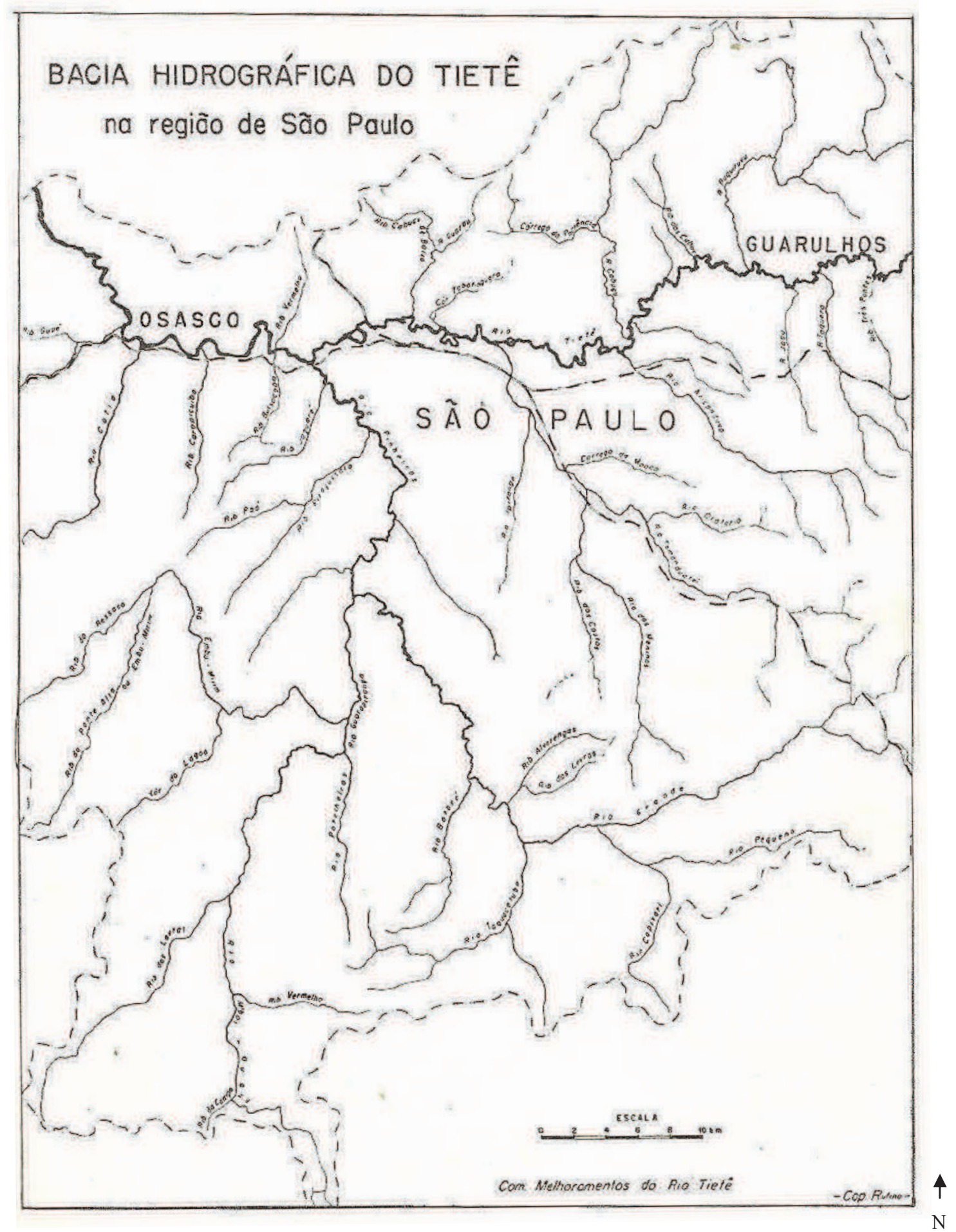

Fonte: Santos (1958, p. 49). 
Originariamente a ocupação da Capital ocorreu na margem esquerda do rio Tietê que serviu de divisor para a fixação humana em relação a sua margem direita; o núcleo primitivo colonial foi se desenvolvendo, juntamente e em menor proporção, a região de Santo Amaro, também na margem esquerda do Tietê e à sudoeste de São Paulo.

$\mathrm{O}$ rio Tietê percorre um vale sinuoso desde a sua nascente na Serra do Mar além das proximidades de Santana de Parnaíba, onde se construiu a primeira grande usina hidrelétrica do Estado para atender à Capital. Esse trecho de aproximadamente 250 quilômetros constitui o denominado Alto Tietê.

A bacia hidrográfica do Alto Tietê tem seus principais afluentes na margem esquerda ou ao sul do vale principal, com $3.237 \mathrm{~km}^{2}$ ou $81,3 \%$ correspondem a essa porção da bacia e em geral seus vales são abertos em forma de ' $U$ ' com numerosos meandros. Os afluentes meridionais principais são da bacia do Tamanduateí, que corresponde a $11,4 \%$ da área total e os da bacia do rio Pinheiros, que corresponde a $45,6 \%$.

Notadamente, foi na bacia do Pinheiros que ocorreu a grande transformação paisagística, sobressaindo as obras de engenharia na bacia de seu subafluente: o rio da formação da represa abastecida pelas águas do Guarapiranga $\left(646,70 \mathrm{~km}^{2}\right)$ e de outros rios e córregos de menor porte provenientes de áreas circunvizinhas, cuja região passou por uma notável mutação e criou uma paisagem inteiramente nova nas bordas meridionais do Planalto Paulistano (SANTOS, 1958, p. 51 e 52) ${ }^{2}$.

Toda a região do Alto Tietê está localizada na unidade geomorfológica denominada Planalto Paulistano, uma subdivisão do Planalto Atlântico que é dividido em dois compartimentos distintos:

\begin{abstract}
A Borda Cristalina e a Bacia Sedimentar de São Paulo. A Borda Cristalina envolve a Bacia Sedimentar a leste, sul e oeste (ao norte tem-se a Serra da Cantareira) e é formada por rochas cristalinas suscetíveis à erosão quando a vegetação é retirada; apresenta altitudes entre $850 \mathrm{~m}$ e $1.100 \mathrm{~m}$, fortes declividades, intenso conjunto de rios, inclusive com nascentes importantes [...] (CUSTÓDIO, 2012, p. 28).
\end{abstract}

\footnotetext{
${ }^{2}$ A bacia do rio Grande $\left(436,35 \mathrm{~km}^{2}\right)$, subafluente do rio Pinheiros, foi posteriormente represada para a construção da represa Billings (1925-1927), constituindo, juntamente com a Guarapiranga, um grande complexo no represamento de águas.
} 
A represa Guarapiranga encontra-se no sul dessa Bacia Sedimentar

[...] constituída por sedimentos, como areia, argila e cascalhos. Possui $40 \mathrm{~km}$ de largura, no sentido norte-sul e cerca de $60 \mathrm{~km} \mathrm{a}$ $70 \mathrm{~km}$ no sentido leste-oeste. Aninhada quase no centro do Planalto Paulistano apresenta altitude entre $718 \mathrm{~m}$ e $830 \mathrm{~m}$, configurando: planícies, terraços, colinas, patamares, rampas e espigões. Formas esculpidas pelo clima e pelo rio Tietê e seus afluentes num lento trabalho de erosão e deposição de sedimentos ao longo dos séculos. A amplitude topográfica na Bacia Sedimentar, que pouco ultrapassa os $100 \mathrm{~m}$, facilitou a ocupação (CUSTÓDIO, 2012, p. 28).

O rio Tietê em seu alto curso, conforme Custódio (2012), engloba a Capital e apresenta uma vazão de $82 \mathrm{~m}^{3} / \mathrm{s}$ de água, um dos fatores que despertou o interesse da companhia Light na produção de energia elétrica e serviu como aporte hídrico para a sua primeira hidrelétrica, localizada à jusante na mesma bacia do Alto Tietê, no momento da construção no início do século XX.

A bacia hidrográfica que formaria a represa Guarapiranga situa-se na porção sudoeste do município de São Paulo e seria criada com o intuito de regularizar a vazão do rio Tietê e aumentar a capacidade de geração de energia na Usina de Parnaíba (atual Santana de Parnaíba, município a noroeste de São Paulo) que tinha sua produção comprometida em épocas de estiagem. O represamento das águas iniciou-se para o fornecimento de energia elétrica, mas na década de 1930 assumiu também a importante função de distribuição de água para o consumo populacional da região.

Como nos diz Custódio (2012, p. 25), é importante se ter a noção da relação existente entre urbanização (processo) e cidade (forma); da base físico-natural sobre a qual foi erigida (sítio urbano) e dos agentes (Light e poder público) apropriadores dos recursos hídricos da região para um fim específico (produção de energia elétrica), em prejuízo de outros usos possíveis, fato que varia de acordo com o tempo histórico. Assim, naquele momento, menosprezava-se o potencial dos reservatórios e o tratamento adequado da água para o abastecimento populacional, em um espaço urbano em constante crescimento.

As obras de engenharia, de que resultou o sistema hidrelétrico de São Paulo, puderam efetivar-se graças às condições favoráveis apresentadas pelo Planalto Atlântico. De início, a Light aproveitou-se de pequenas quedas de água relativamente próximas à Capital, principalmente no trecho encaixado do rio Tietê, situado nos limites 
norte ocidentais do Planalto (Parnaíba), cuja potência foi aumentada por meio de represamentos (Guarapiranga), assim a cidade de São Paulo começou a contar com serviços de energia elétrica mais efetivos para as atividades que nela se desenvolviam.

A construção da primeira usina hidrelétrica de grande porte no Estado, feita pela Light iniciou-se

após barrar o rio Tietê a $33 \mathrm{~km}$ da Capital e aproveitando uma queda de água natural existente junto à cidade de Santana de Parnaíba, na altitude de 711 metros acima do nível do mar. Foi assim que surgiu a usina de Parnaíba [...] inaugurada em 1901, contando com 2 alternadores de $1000 \mathrm{kw}$ (RADESCA, 1958, p. 107).

O regime do rio Tietê está correlacionado com o regime pluviométrico regional e caracteriza-se pelas chuvas abundantes no verão e pela estiagem no inverno, apresentando grande amplitude anual da sua vazão. Em consequência, e, sobretudo, quando se prolongava anormalmente o período de estiagem, a usina hidrelétrica de Parnaíba (denominada atualmente Edgard de Sousa), apesar de possuir um reservatório de água, passou a enfrentar problemas de escassez. Por isso tornou-se necessário a construção do represamento das águas do rio Guarapiranga, um subafluente do rio Tietê, que drena extensa área do Planalto Paulistano e cuja obra iniciou-se em 1906.

O Reservatório do Guarapiranga encontra-se ao nível de 736,62 metros, com um perímetro de $135 \mathrm{~km}$ e uma área de $33,9 \mathrm{~km}^{2}$, armazenando um volume de 196 milhões de $\mathrm{m}^{3}$ (o que equivale a uma energia potencial de 300 milhões de $\mathrm{kWh}$ ). A principal barragem desse reservatório mede $1.640 \mathrm{~m}$ de comprimento por $19 \mathrm{~m}$ de altura, tendo sido sua principal finalidade aumentar o volume das águas do rio Tietê, durante as estiagens, garantindo assim o funcionamento regular da 'Usina Edgard de Sousa'[...] (RADESCA, 1958, p. 107).

Segundo Whately e Cunha (2006, p. 7), a bacia hidrográfica da Guarapiranga conta com uma área de drenagem de $639 \mathrm{~km}^{2} \mathrm{e}$ "na sua parte mais funda, perto da barragem, a profundidade era de $13 \mathrm{~m}$ e no restante a média era de $6 \mathrm{~m}$ " 3 . Esses números, referentes a perímetro, altura e profundidade da represa, à época da sua construção, apresentam oscilações entre alguns autores pesquisados, porém, as

\footnotetext{
3 “A partir de 1928, a represa da Guarapiranga tornou-se a principal fonte de água para abastecimento publico de São Paulo, mediante o fornecimento de 86,4 milhões de litros de água por dia (vazão média de $1 \mathrm{~m}^{3} / \mathrm{s}$ ) para a Estação de Tratamento de Água de Teodoro Ramos" (WHATELY; CUNHA, 2006, p. 9).
} 
variações são poucas e não alteram significativamente o quadro geral de referências da obra (Radesca,1958; Whately e Cunha, 2006; Santos 1958).

Ainda, quanto à construção da represa Guarapiranga, segundo Mello (2011, p. 144), a barragem

[...] situada no principal afluente do rio Pinheiros, tributário do rio Tietê [...] é de terra com $15,6 \mathrm{~m}$ de altura e $1.500 \mathrm{~m}$ de crista. Seu volume de $505.000 \mathrm{~m}^{3}$ foi proveniente de área de empréstimo escavada à mão, o solo foi transportado por tração animal e compactado apenas com a passagem das carroças. Como elemento de impermeabilização foi executada uma cortina de estacas-prancha na linha de centro da barragem.

A represa Billings, para efeito de comparação e em virtude da sua localização geográfica na bacia hidrográfica do Alto Tietê, teve em sua gênese uma mesma função que a Guarapiranga: a produção de energia elétrica. Embora em período posterior e de dimensões físicas maiores ${ }^{4}$.

A construção da Billings foi motivada principalmente por uma estiagem de grandes proporções ocorrida em São Paulo, em 1924, quando as águas do rio Tietê baixaram para cerca de 30\% de seu volume e em maio de 1925, 70\% da energia elétrica da cidade teve de ser cortada, trazendo inúmeras consequências, como a interrupção da iluminação pública e o funcionamento das fábricas passaram para apenas três dias por semana (BERARDI, 1981, p. 100).

As duas construções são obras da moderna engenharia da primeira metade do século $\mathrm{XX}$, que impôs ao sítio natural as técnicas para um espaço a ser conquistado e adequado segundo os padrões e necessidades da época ${ }^{5}$.

A represa Billings ${ }^{6}$, também construída pela Light, a partir de 1925, armazenava água para gerar energia, neste caso, na usina hidrelétrica localizada em Cubatão, na

\footnotetext{
4 As extensões perimetrais são: $135 \mathrm{~km}$, no reservatório do Guarapiranga e $800 \mathrm{~km}$, no reservatório Billings (RADESCA, 1958, p. 118).

5 Posteriormente, com o aumento populacional e a demanda, novas usinas surgiram: a de Itupararanga, nas cabeceiras do rio Sorocaba, em 1914; a do Rasgão, em Cabreúva, em 1925, ambas próximas e em uma mesma região: ao oeste da Capital. (MATTOS, 1958, p. 21-22).

6 Represa Billings: batizada com o nome do engenheiro norte americano, Asa White Kenney Billings, (EUA, 1876-1949), um dos idealizadores da represa na década de 1930 e funcionário da Light. É considerado um dos pioneiros no desenvolvimento dos sistemas de energia elétrica no Brasil.
} 
baixada litorânea. Para tanto, suas obras contaram com uma dificuldade maior, pois as águas teriam que transpor a Serra do Mar localizada a sudeste e despencar

[...] 800 metros de altura sobre as turbinas da Usina de Cubatão, que iria suprir São Paulo da energia que faltava. A estas águas se acrescentaram as do reservatório do Guarapiranga, e as do próprio rio Pinheiros, impulsionadas em sentido inverso por um canal (BERARDI, 1981, p. 100).

Ainda, chamou-nos a atenção um relato proferido pelo Chefe da Comissão Geográfica e Geológica de São Paulo $^{7}$ de 1905, acerca da exploração do rio Tietê quanto aos seus elementos físicos na inter-relação com o homem:

As águas do vale do Tietê já prestam uma valiosa contribuição para o desenvolvimento de nossas indústrias. Basta notar que na Capital e em muitas cidades do interior vemos instalações elétricas de força e luz, fábricas diversas etc., que se utilizam deste grande agente com que a natureza foi prodigiosa para conosco, em sua distribuição (Derby apud FIGUEIRÔA, 2008, p. 6).

A imperiosa necessidade de abastecer de energia elétrica a cidade de São Paulo e sua área de influência ocasionaram profundas alterações na paisagem e foi a rede hidrográfica, sem nenhuma dúvida para Radesca (1958), o elemento natural que maiores transformações veio a sofrer, como as águas da bacia do rio Guarapiranga, com seus tributários Embu Mirim e Embu Guaçu, mais tarde as águas do rio Grande, para movimentar a usina em Cubatão. Essas águas foram represadas e deram origem, na porção sudoeste-sudeste da Capital, a uma paisagem inteiramente nova, com a formação de grandes lagos artificiais que passaram a ocupar extensas áreas do Planalto Paulistano com, inclusive, a alteração significativa da 'cartografia' da região ${ }^{8}$.

\footnotetext{
${ }^{7}$ Comissão Geográfica e Geológica de São Paulo (CGG de SP), criada pela Lei Provincial $\mathrm{n}^{\circ}$ 9, de 27.03.1886 e extinta em 1931, dando origem a importantes instituições de pesquisa do Estado como o Instituto Florestal e o Museu Paulista.

${ }^{8}$ Com a represa Billings e na década de 1940, boa parte das águas represadas passaram a ser drenadas diretamente para o oceano Atlântico, ao invés de contribuírem para o engrossamento do rio Tietê e, através deste, para o rio Paraná. Igual inversão no sentido da corrente foi feito em relação às águas do rio Pinheiros, cujo vale passou por importantes transformações: canalização do curso, desaparecimento de meandros, aprofundamento do talvegue, aterro das várzeas (RADESCA, 1958).
} 
A energia elétrica conquistava importantes setores e atividades da vida urbana e, ao mesmo tempo, a construção de represas para hidrelétricas passava a ser utilizada como geradora de força motriz para o nascente parque industrial e como principal fonte energética para o país.

\section{2 - Café e ferrovia: o início das grandes alterações da paisagem}

A construção da represa Guarapiranga está relacionada a diversos fatores que culminaram na sua edificação. Dentre eles está o desenvolvimento econômico do Brasil inserido na divisão internacional do trabalho pela produção e exportação de produtos primários, de baixo valor agregado, como o caso do café, produzido em larga escala em boa parte do sudeste brasileiro.

Tal fato inicia-se pujantemente na segunda metade do século XIX, quando ocorre o firmamento do café como principal produto agrícola do país, modificando sobremaneira a paisagem e cujos instrumentos necessários foram as transformações técnicas, sociais e econômicas produzidas, associadas às mudanças igualmente ocorridas na Europa (MONBEIG, 1984).

Foi nesse mesmo período que os capitalistas europeus, sobretudo ingleses, investem significativamente no país. "Desde o seu início, a marcha para o oeste [do território paulista] foi um episódio da expansão da civilização capitalista, surgida nas duas margens do Atlântico. Ambas não cessaram de ser solidárias" (MONBEIG, 1984, p. 105).

São Paulo já havia conhecido uma fase agrícola importante, segundo Mattos (1958), com o algodão e que correspondeu ao período de 1860 até 1880, com sementes da espécie herbácea provenientes da Inglaterra, sendo plantadas em solos onde o café não havia penetrado, quer em virtude do tipo de solo, do relevo ou em terras já esgotadas pelos cafezais, vicejando na Baixa Sorocabana, muito favorecido pelos reclamos do comércio internacional, com o desenvolvimento da indústria têxtil inglesa prejudicada pela guerra de Secessão dos Estados Unidos, grande fornecedor do mercado inglês. 
Com a retomada da plantação algodoeira no sul dos Estados Unidos, após a guerra civil, este passou a ser o grande fornecedor para o mercado inglês e a partir de 1877 inicia-se o declínio da lavoura paulista, que não desapareceu por completo, graças ao surgimento das primeiras fábricas de tecidos que aproveitavam o excedente da exportação paulista. Vale ressaltar que desde o período colonial havia a plantação algodoeira, com o algodão arbóreo nativo, para atender as necessidades da modesta indústria têxtil de caráter doméstico (MATTOS, 1958, p. 15-17).

Mas, conforme Mattos (1958, p. 7-10), não há dentro do mundo tropical fenômeno agrícola comparável ao do café no Estado de São Paulo, que expandiu por suas terras contribuindo vertiginosamente para transformar, em menos de um século, a sua paisagem geográfica, povoando-a e urbanizando-a.

Já no primeiro decênio após a independência política do Brasil, ocorrida em 1722, o café contribuía com dezoito por cento do valor das exportações, “[...] colocando-se em terceiro lugar depois do açúcar e do algodão. E nos dois decênios seguintes já passa para primeiro lugar, representando mais de quarenta por cento do valor das exportações" (FURTADO, 2015, p. 169).

O café foi introduzido no Brasil via Pará, no começo do século XVIII e teve o cultivo espalhado por grande parte do território brasileiro para fins, sobretudo, de consumo local e, pela metade do século XIX, a produção cafeeira estava se definindo como o novo produto agrícola do país e cujas características de produção correspondiam às condições ecológicas do sudeste brasileiro.

A cafeicultura no planalto paulista foi orientador do povoamento, sempre em busca de novas terras férteis assim que o solo ia se esgotando. Os fazendeiros promoviam em meio à vegetação original derrubadas e queimadas de árvores para dar lugar aos cafezais, com suas fazendas e núcleos urbanos que floresciam ao redor. Após sua penetração em São Paulo e em menos de cem anos alcançou as margens do rio Paraná, inundando o norte paranaense com suas folhagens.

Os empreendimentos de capital estrangeiro foram logo atraídos pelo desenvolvimento econômico promovido pelo projeto agrícola cafeeiro, que investiu em ferrovias e em energia elétrica por meio da força motriz das águas, exigindo a construção de hidrelétricas e reservatórios para o seu funcionamento, adequando-se, assim, a transformação territorial às novas exigências do capital. 
Para tanto havia a necessidade de substituição da mão de obra escrava africana para a assalariada e o fluxo migratório europeu foi a solução despontada para o trabalho agrícola, fabril e das infraestruturas urbanas, sobretudo após a libertação dos escravos em 1888, fato já observado com a proibição do tráfico negreiro em 1850, que tornava o escravo cada vez mais caro, além de fomentar o mercado consumidor interno (MATTOS, 1958, p. 11-12).

No Estado de São Paulo no final do século XIX e início do XX ocorria o aumento populacional proporcionado principalmente pela imigração europeia aliada à expansão econômica para o oeste, atendendo às crescentes produções agrícolas cafeicultoras e proporcionado principalmente pela instalação de redes ferroviárias (MILLIET, 1982).

Inicialmente a produção do café para exportação concentrou-se em terras montanhosas próximas ao Rio de Janeiro, então Capital do país, que contava com relativa abundância de mão de obra, em consequência da desagregação da economia mineira, a proximidade do porto marítimo para transporte e a grande quantidade de mulas que transportava o café para o porto. Destarte, utilizaram-se recursos preexistentes e subutilizados nessa fase inicial da expansão cafeeira, posteriormente adentrada no vale do Paraíba fluminense e paulista.

No terceiro quartel do século XIX, segundo Furtado (2015), ocorre a fase da gestação da empresa cafeeira, com a utilização intensiva da mão de obra escrava, proveniente da região de mineração e daquela pressionada no sentido da transferência do nordeste açucareiro para o sudeste, isso tudo favorecido em face do preço do café em recuperação, enquanto o do açúcar permanecia em queda.

Nas décadas finais do século XIX, o café era o principal produto que integrava o Brasil no mercado internacional, incorporando o país "[...] nas correntes em expansão do comércio mundial" e configurando sobremaneira a ocupação humana no território brasileiro. Essa importância comercial do café foi também em virtude da alta dos preços causada pela desorganização do grande produtor mundial: a colônia francesa do Haiti (FURTADO, 2015, p. 172).

Com o crescimento das plantações, o café foi penetrando progressivamente para o interior paulista, sempre atraído por melhores solos e se distanciando cada vez mais do seu porto exportador, fazendo do transporte em lombo de burro tornar-se cada vez 
mais difícil e oneroso e impondo nova forma de transporte, exigindo, naquele momento, a implantação das estradas de ferro para a condução do café (MATTOS, 1958).

O chamado oeste de São Paulo, mais precisamente a zona noroeste do Estado, região de Campinas, apresentava certas vantagens em relação ao vale do Paraíba. A nova região possuía planícies amplas, onduladas, retendo por mais tempo as riquezas do solo, facilitando a abertura de uma densa rede de estradas de ferro e de rodagem. O solo, produto da decomposição de rochas basálticas de origem vulcânica era extremamente favorável à plantação do café (MORSE, 1970, p. 159).

Plantar café além de Rio Claro, cerca de quarenta léguas de Santos (180 km), era considerado um verdadeiro absurdo, pois o frete consumia todo o investimento, por melhor que fosse a produção (MORSE, 1970, p. 191).

Em 1867 a Serra do Mar é transposta pela Estrada de Ferro Santos-Jundiaí, a The São Paulo Railway Company Ltd.. Outras logo surgiram neste amplo movimento ferroviário: a Sorocabana, em 1870, a Mogiana, em 1872, transformando o porto de Santos no porto do café, o mais importante do pais já em 1892, fato que exigia maiores instalações portuárias e o saneamento urbano da cidade santista, além da Capital (MATTOS, 1958, p. 9).

A construção da ferrovia não foi simples, tanto que o engenheiro-chefe inglês da São Paulo Railway já se queixava, em 1862, sobre a difícil tarefa de transpor a Serra do Mar, por meio da mata densa e com toda uma fauna a espreitar (MORSE, 1970), mas as técnicas da época permitiram tal feito e

por fim os técnicos britânicos venceram os 793 metros da Serra, por meio de uma série de planos inclinados, com um declive de $10 \%$, e locomotivas estacionárias para fazer descer e subir os trens por meio de cabos. A 16 de fevereiro de 1867 os 139 quilômetros da linha Santos a Jundiaí foram abertos ao tráfego (MORSE, 1970, p. 206).

Por um breve período de tempo o êxito da estrada de ferro foi posto em perigo pelas reduzidas taxas dos tropeiros competidores. Estes haviam sido beneficiados pela construção, na década de 1860, de uma estrada nova e melhor através da Serra, construída ostensivamente com o propósito de baixar os fretes da estrada de ferro.

Os serviços dos tropeiros continuavam intensamente a ser utilizados, fazendo o serviço porta a porta, das fazendas às estações, mas logo a estrada de ferro com suas rotas foi se impondo (MORSE, 1970, p. 206). 
As ferrovias, ao substituírem o transporte realizado por tropas de mulas, influenciavam na formação do preço do café, porém, segundo Saes (1986, p. 64), essa substituição foi progressiva e a cada inauguração de um trecho de linha férrea deslocava as tropas para as áreas mais ao Oeste e o efeito mais evidente da ferrovia foi a redução do custo de transporte ao qual se associavam a maior segurança e a regularidade no transporte. Notamos, conforme observação de Morse (1970, p. 206), que o quantitativo de passageiros e mercadorias transportadas pela ferrovia nos cinco primeiros anos da sua existência teve progressivo aumento, fato que contribuiu para dinamizar a ocupação territorial e a alteração da sua fisionomia paisagística.

Deve-se considerar no processo de desenvolvimento ferroviário a relação tanto com a produção quanto com a circulação, além do já mencionado efeito imediato da redução do custo de transporte, reflexo do menor trabalho necessário para realizar o transporte de café e, ainda, a maior eficiência da ferrovia frente às tropas de mula.

Conforme nos atenta Saes (1986), não há clareza suficiente sobre a utilização da mão de obra liberada no transporte do café na realização de outras atividades, um dos motivos é que a empresa de transporte no sistema de tropas era tipicamente a empresa individual e nem sempre pertencente ao fazendeiro, mas o autor nos afirma que no caso de São Paulo, em torno de 1870, tal fato apresenta enorme importância especialmente pela forma que assume a redução do trabalho necessário, e complementa que "o transporte por tropas de mula se realizava com base no trabalho escravo, ao passo que as ferrovias prescindiam dessa força de trabalho (SAES, 1986, p. 65).

As ferrovias liberaram parte dos escravos ocupados na atividade de transporte e possibilitaram seu uso no trabalho propriamente agrícola, um problema grave a ser solucionado pelos fazendeiros. Desse modo, quando se estabelecem as ferrovias ocorre uma concentração maior de mão de obra em torno de algumas empresas ferroviárias dos grandes fazendeiros, o que possibilitou aumentar a concentração da riqueza na economia paulista em torno de um grupo relativamente pequeno de pessoas (SAES, 1986, p. 67).

A introdução das ferrovias trouxe ainda outras mudanças quando comparadas às tropas de mulas. Esses animais necessários ao transporte eram obtidos no Sul do País e eventualmente na região do Prata, para serem comercializados em Sorocaba ou Jundiaí.

Os trabalhadores no sistema de tropas eram brasileiros livres ou escravos que, em torno de 1870 , só podiam ser obtidos internamente dada à cessação do tráfico em 
1850. Desse modo, Saes (1986) afirma que o transporte era feito com recursos nacionais e praticamente não se dependia de importações para tornar possível a realização do valor da mercadoria, considerada apenas sua venda ao exportador que o embarca nos navios rumo à Europa ou Estados Unidos.

Já com as ferrovias a situação alterou-se: agora os equipamentos (trilhos, locomotivas, vagões etc.) são necessariamente importados, assim como o combustível (carvão, embora houvesse a produção de lenha local) e os lubrificantes. Nas fases de implantação das ferrovias até mesmo alguns trabalhadores eram trazidos do exterior. Surge, assim, na economia cafeeira, um elemento que indica a internacionalização dos meios de produção, na medida em que esses meios necessários à atividade de transporte dependem de importação e esta se faz exatamente dos países capitalistas centrais (no primeiro momento, da Inglaterra e de alguns outros países europeus), criando um vínculo cujos reflexos tendem a se tornar mais claros nos momentos de crise da economia (SAES, 1986, p. 66).

Nota-se que o capital cafeeiro no final do século XIX se afirma e se difunde para outros setores, avançando rumo às ferrovias e ainda a alguns serviços urbanos. O grande capital procura aprofundar seu domínio nesses setores e diversificar seu investimento nas atividades bancárias, comerciais e a indústria, supondo um certo modo de articulação entre fazendeiros de café, empresas ferroviárias e de alguns serviços urbanos que já se encontravam na Capital da Província nas décadas finais de 1800.

A atividade cafeeira, além de constituir em fator de povoamento e alteração paisagística, possibilitou o acúmulo de capitais e movimentou os primeiros surtos na indústria e o surgimento de alguns bancos, como o Banco Mercantil de Santos, em 1872 e o Banco de Crédito Real de São Paulo, em 1882 (MATTOS, 1958, p. 9) e ainda, o estabelecimento de empresas estrangeiras. Entretanto, como salienta Saes (1986, p. 140), "mais importante do que a existência do capital estrangeiro em empresas no Brasil deve ser sua posição dentro da economia a cada momento. E esta posição parece estarse modificando significativamente nos fins do século XIX".

Nesse cenário estão sendo pensadas formas de obtenção e produção de novas fontes de energia a fim de garantir o desenvolvimento econômico e sustentar o aumento populacional nas áreas urbanas.

No mapa (Figura 2) associado à tabela (Tabela 1), a seguir, observamos o aumento populacional e consequentemente o surgimento de cidades no chamado oeste 
paulista, muito relacionado à implantação das linhas férreas em decorrência da produção cafeeira. Podemos associar, ainda, o registro da entrada de imigrantes no Estado de São Paulo, em boa parte para trabalhar no cultivo cafeeiro, no qual Monbeig (1984) nos atenta que juntamente à imigração estrangeira está associada a imigração nacional para São Paulo. 
Figura 2 - Representação espacial da cultura cafeeira e as estradas de ferro no Estado de São Paulo, início do século XX

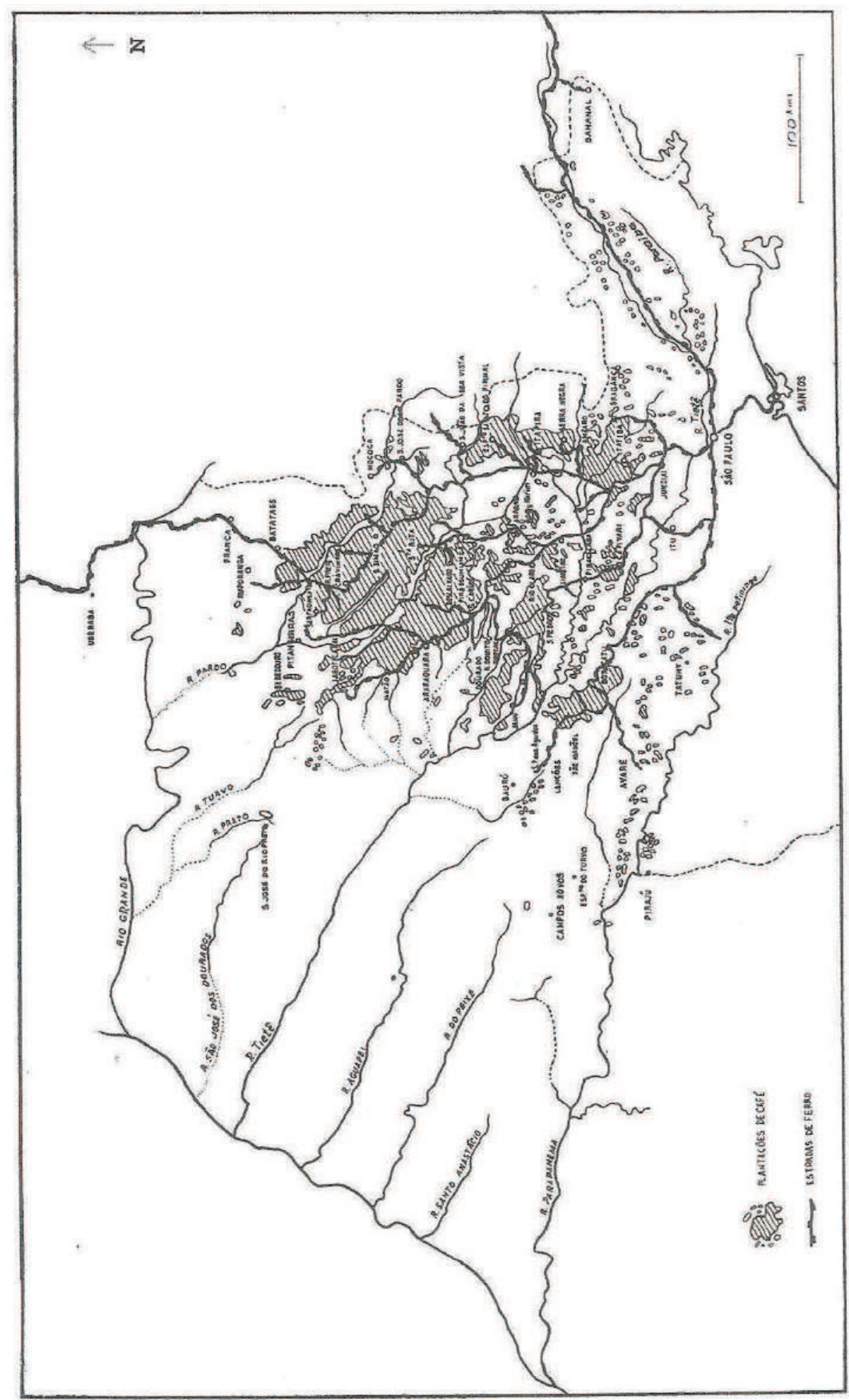

Fonte: Monbeig (1984, p. 169). 
Tabela 1 - A evolução populacional, ferroviária e o café no Estado de São Paulo, de 1860 a 1920

\begin{tabular}{c|r|r|r}
\hline ANO & $\begin{array}{c}\text { HABITANTES - } \\
\text { ESTADO DE SÃO } \\
\text { PAULO }\end{array}$ & $\begin{array}{c}\text { KM - ESTRADAS } \\
\text { DE FERRO } \\
\text { CONSTRUÍDAS }\end{array}$ & $\begin{array}{c}\text { CAFEEIROS - } \\
\text { PÉS DE CAFÉ }\end{array}$ \\
\hline 1860 & 685.000 & 0 & 26.800 .000 \\
\hline 1870 & 830.000 & 139 & 60.462 .000 \\
\hline 1880 & 1.107 .000 & 1.212 & 69.540 .000 \\
\hline 1890 & 1.385 .000 & 2.425 & 220.000 .000 \\
\hline 1900 & 2.279 .000 & 3.373 & 696.701 .545 \\
\hline 1910 & 2.800 .400 & 4.825 & 826.644 .755 \\
\hline 1920 & 4.592 .188 & 6.616 & \\
\hline
\end{tabular}

Fonte: Matos (1990, p. 105). Adaptação do autor (2018).

O crescimento da cidade de São Paulo, a que mais se desenvolvia na então Província a partir da década 1870/1880, teve também como motivação o êxodo de populações rurais e urbanas, oriundas do interior e de outras regiões do País, atraídas pelas vantagens, reais ou supostas, do novo dinamismo da cidade ou em busca de trabalho; o loteamento de grandes propriedades, como chácaras, sítios na cidade ou nas áreas suburbanas, resultando a proliferação de novos bairros e consequente ocupação (AZEVEDO, 1958, p. 12-13).

Tudo muito relacionado com a economia cafeeira, que em uma análise acerca da exportação e a relação com a imigração, nos é informado que:

O volume de café exportado por Santos cresceu de 2,5 milhões de sacas na safra de 1888-1889 para 7,8 milhões de sacas na safra de 1900-1901.

[...] a grande imigração, intensificada a partir de 1888, manteve-se em níveis elevados nos anos 90: a proporção de estrangeiros na Província e no Estado de São Paulo aumentou de $3,7 \%$, em 1872, para 5,7\%, em 1890 , e para $30,2 \%$, em 1900 (SAES, 2004, p. 219).

Não podemos deixar de mencionar que o valor do café no cenário internacional e sua produção no Brasil não foram uma constante. No período que mais nos interessa, final do século XIX e início do XX, sobretudo entre os anos de 1900 e 1910, cujo movimento e conquista do solo consistia em grande parte especulação financeira 
favorecida pelo ambiente da produção cafeeira, ocorria a depreciação do câmbio brasileiro fato que beneficiava aparentemente a exportação, contudo o preço do café sofria queda no mercado externo. A superprodução cafeeira em São Paulo aumentou muito nos anos iniciais do século XX e mesmo estimando a espera de um período de cinco anos para a plantação frutificar, rendosas colheitas foram ofertadas no mercado, chegando em 1903 a possuir um estoque de 70\% do consumo mundial para um ano, fazendo os preços caírem aos níveis dos anos iniciais de 1880, com o agravante dos custos de produção não diminuídos, ao contrário, acrescidos consideravelmente (MONBEIG, 1984, p. 108-109).

O gráfico (Figura 3) da produção e preço do café, no porto de Santos, demonstra a relação díspar, no período de 1880 a 1912, como mencionado.

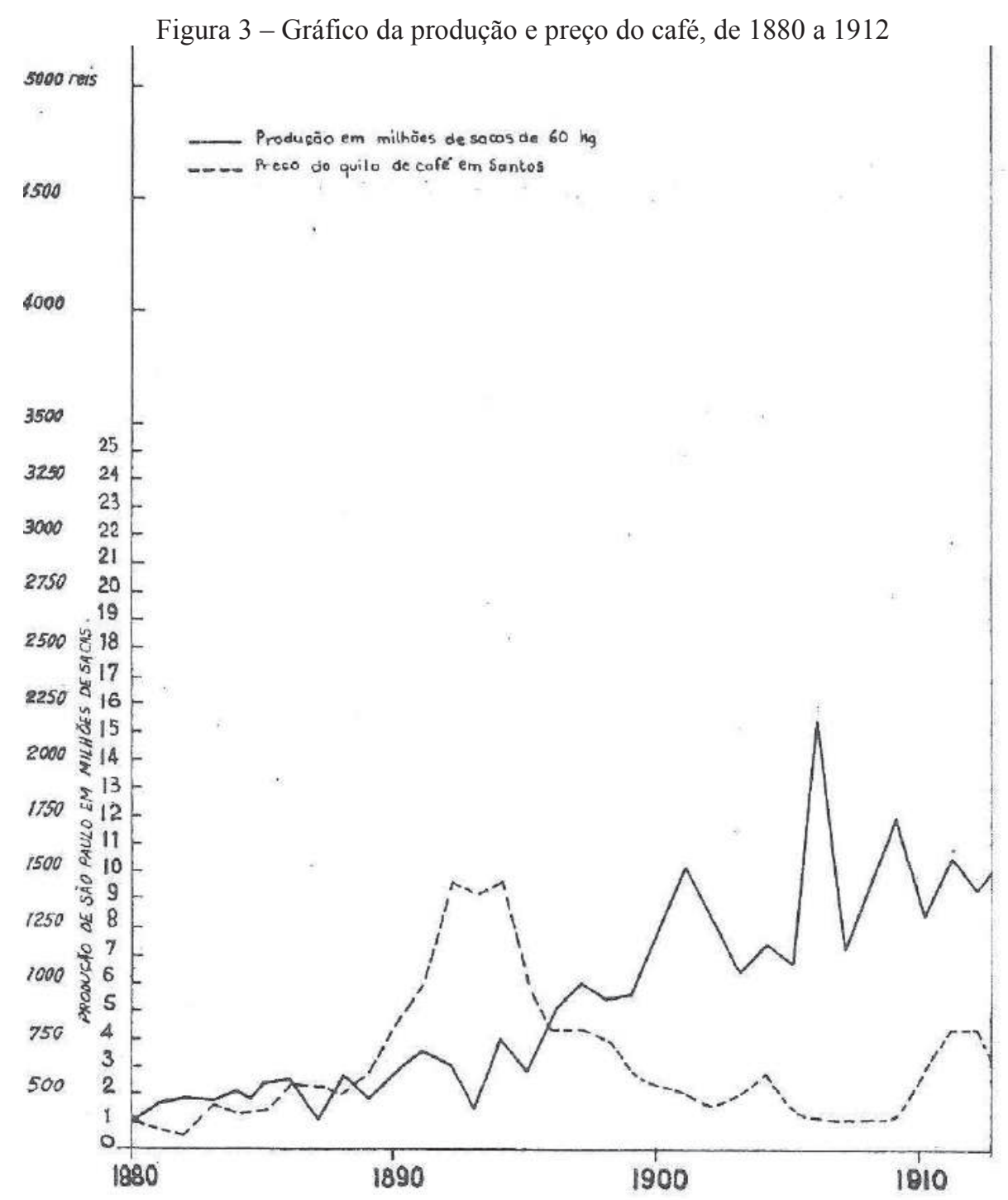

Fonte: Monbeig (1984, p. 110). Adaptação do autor (2018). 
A solução encontrada para proteger a produção cafeeira brasileira, no período de preços baixos e de grande colheita, deu-se por meio do Convênio de Taubaté ${ }^{9}$, em 1906, que estabeleceu um acordo entre os governadores dos principais Estados produtores (São Paulo, Minas Gerais e Rio de Janeiro), instituindo, dentre outras coisas, preços mínimos para a compra do excedente pelos governos e intervenção federal em benefício dos cafeicultores, como a emissão lastreada em empréstimos externos e desenvolvendo políticas de valorização do café.

Todavia, a liderança da agricultura cafeeira no país continuou em primazia. No decênio de 1901-1910 representava 51,46\% e no decênio de 1911-1920 representava $52,40 \%$ do total da exportação brasileira, sofrendo revés somente com a crise capitalista de 1929 (ARAÚJO FILHO, s.d., p. 53-54).

O café dinamizava as funções urbanas, sobretudo da cidade de São Paulo, por meio do crescente comércio, pela multiplicação das ocupações profissionais, pela ampliação e complexidade das funções burocráticas da Capital que se enriquecia e exigia um número maior de funcionários públicos para atender as atividades estatais, pela imigração e pelo papel cada vez mais importante da cidade no cenário nacional, além de ser passagem entre o interior e o litoral do Estado, fazendo-se necessário a adequação no transporte de mercadorias e pessoas.

Em 1863 os custos de transporte de Campinas a Santos representavam mais de $40 \%$ do preço da exportação do café e com a implantação das ferrovias ocorreu a redução dos custos de frete e na década de 1920, as despesas com transporte representavam pouco mais de um décimo dos gastos correntes incorridos pelos fazendeiros (LOVE, 1982, p. 68).

Essa malha visava a atender aos interesses dos produtores e alterava sobremaneira a paisagem paulista e fomentava a criação de novas cidades por onde as linhas férreas passavam e a deterioração e decadência de outras, que viam seus espaços radicalmente alterados pela dinâmica da apropriação territorial capitalista, como retratado em Cidades mortas $^{10}$, de Monteiro de Lobato.

\footnotetext{
9 A cidade de Taubaté localiza-se no vale do rio Paraíba do Sul, região onde iniciou a monocultura cafeeira no Estado de São Paulo.

${ }^{10}$ Livro de contos escrito por José Bento Renato Monteiro Lobato (Taubaté, 1882 - São Paulo, 1948), publicado em 1919. Os contos falam sobre a decadência econômica, a queda da produção cafeeira e o cotidiano das cidades paulistas do Vale do Paraíba, região por onde o café foi introduzido no Estado e que, conforme Matos (1990), utilizavam-se os portos fluminenses de Parati e Angra dos Reis para escoamento da produção cafeeira.
} 
Dentro desta lógica, as cidades promoviam a reprodução do sistema agroexportador, pois tinham uma posição bem definida junto à economia e deveriam, conforme Campos (2015, p. 20), funcionar como um centro de apoio às atividades agrícolas, sediando todo um conjunto de serviços e com um sistema de transporte mais eficiente.

O chamado complexo cafeeiro transformou a fisionomia da cidade de São Paulo, tornando-a, nos dizeres de Ribeiro (1993, apud CAMPOS, 2015, p. 20): “a capital do capital". São Paulo era o centro econômico, a Capital do capital cafeeiro e da industrialização incipiente, onde, nas primeiras décadas do século XX, Campinas passa a ser a capital da região produtora e Santos a capital exportadora (TOLEDO, 2015, p. 27 e 107).

Um cinturão de pequenas propriedades rurais que cercavam a Capital de 1875 a 1915 iam se transformando, se urbanizando. A área da cidade dobrou entre 1899 e 1909 e os serviços urbanos estavam sempre aquém das necessidades da sua população e suas águas, sempre importantes na configuração espacial, fez com que o governo estadual, em 1892, concordasse com os estudos de canalizar parte dos rios Tietê e Tamanduateí, que cortam a cidade, além de implantar uma comissão de saneamento destinada a erradicar a malária na várzea do rio Tietê (LOVE, 1982, p. 120-121).

A maioria dos imigrantes se dirigiu para as áreas rurais, mas certo número instalou-se na Capital. Em 1886, antes do início da imigração em massa, os estrangeiros constituíam um quarto da população da cidade de São Paulo (LOVE, 1982).

Novas estruturas surgiram no esforço de adequar à cidade as suas novas funções e sua imagem fisionômica tentava romper com o antigo arcabouço colonial e espelhar o que havia de novo. Isso continha em seu bojo a ideia de progresso e contagiava a classe hegemônica política e econômica, cuja atuação, paralela ao crescente dinamismo do ambiente urbano que ampliava a vida cultural, promovia mudanças na paisagem da cidade por meio de construções públicas e particulares com estilos arquitetônicos que já não exibiam mais os traços do período colonial e sim do neoclassicismo de marcas europeias, impressas pelos artífices imigrantes (RICARDI, 2013). 
Destaca-se a inauguração da Estação da Luz ${ }^{11}$, em 1901, em São Paulo, porque o edifício representava muito mais que o marco definitivo da presença ferroviária na cidade. A monumentalidade arquitetônica inédita passaria a ser associada à imagem citadina, pois a "sua portentosa arquitetura importada da Inglaterra introduzia na paisagem uma referência que alterava definitivamente o padrão arquitetônico". A então cidade de taipa passou a ostentar um novo estilo em sua feição, como os ferros dependentes das forjas inglesas, escocesas ou belgas (SEGAWA, 2004, p. 367).

$\mathrm{O}$ dinamismo econômico e as transformações territoriais advindas do desenvolvimento capitalista iam além de São Paulo. Lembremos que a partir de 1880 o capitalismo formava um sistema econômico que englobaria grande parte do planeta.

O mercado nacional também se beneficiou com os investimentos que iriam trazer alterações no suporte urbano, cujas aplicações, muitas das quais externas, como na construção das ferrovias e estações, promoviam a implementação de uma nova ordem na circulação de mercadorias pelo território, proporcionando as alterações paisagísticas, sobretudo em São Paulo.

Conforme Ricardi (2013) foram realizadas em São Paulo muitas obras de infraestrutura, de transporte e urbanização, a fim de atender às novas exigências da economia capitalista, que enxergava nas técnicas e na razão humana uma possibilidade de apropriação do espaço em benefício do sistema de produção.

São Paulo tornava-se um centro urbano, industrial, financeiro e político dinâmico, tudo isso muito favorecido pelos implementos oriundos da produção cafeeira e, muito importante, à introdução da energia elétrica e inovações nos meios de transporte urbano, na qual a Light, uma empresa privada de capital estrangeiro, teve um papel preponderante, como veremos mais à frente.

Devemos deixar claro que todo esse processo transformador do espaço urbano foi devido, principalmente, à expansão comercial resultante de uma integração do Brasil no mercado internacional, sob a égide da economia cafeeira, e sujeita às oscilações desse mesmo mercado.

Somando-se às transformações físicas do espaço da Capital paulista, com a construção e adaptação de diversos suportes urbanos, temos também a construção da

\footnotetext{
${ }^{11}$ O nome da região está associado ao Convento da Luz (Nossa Senhora da Luz da Divina Providência, atual Museu de Arte Sacra). Localizada entre as várzeas dos rios Tamanduaté e Tietê, constituía um local a salvo das periódicas inundações e próxima ao Jardim da Luz, inaugurado em 1825, sendo o mais antigo jardim público da cidade de São Paulo (PATACA, 2015).
} 
represa de Santo Amaro (Guarapiranga), outro elemento da alteração paisagística, necessário para a regulação das águas e fornecimento de energia elétrica para a cidade de São Paulo e de importância para o desenvolvimento econômico pretendido para a região.

No Brasil, em fins do século XIX e início do XX, o processo de urbanização progrediu, apesar da base econômica ainda ser o campo. O avanço ocorreu por conta da revolução técnica ensejada pelas ferrovias, pois o binômio porto-ferrovia, a partir de 1860, redesenhou a rede urbana do território, no sentido de torná-la mais dinâmica e complexa; avançou com a entrada e consumo de produtos manufaturados e industrializados no país; avançou em virtude das alterações e apropriações da mão de obra, com o fim da escravidão e a entrada de muitos imigrantes, e, avançou ainda, por conta da necessidade de adequação dos espaços urbanos a uma nova conformidade histórica e adensamento populacional, a exemplo do ocorrido na Europa como as intervenções promovidas pelo Barão de Haussmann ${ }^{12}$ (CUSTÓDIO, 2012, p. 8).

As reformas urbanísticas promovidas na Capital Federal também serviram de modelo para São Paulo, forçando a população menos favorecida economicamente a se mudar para regiões cada vez mais distantes do centro.

Ainda, nesse período de fins do século XIX, a força da mão de obra imigrante remodelava também a paisagem social e entre os diversos europeus recém-chegados à São Paulo, encontravam-se

mestres de obras, construtores e uma gama de artífices diversos que ajudaram a melhorar a qualidade da construção - seja ela de gente remediada como daqueles que se endinheiravam com o café e com os negócios daí derivados. Acima desses quase sempre anônimos obreiros, estavam engenheiros e arquitetos que aqui chegaram para oferecer seus conhecimentos de bemconstruir, bem-morar e bem-exibir (SEGAWA, 2004, p. 367).

Salientamos que no final do século XIX no Estado de São Paulo, inúmeras cidades foram criadas em função da expansão urbana como "frentes pioneiras" (MONBEIG, 1984) da cultura cafeeira para o oeste paulista. As cidades surgiram, em

\footnotetext{
12 Georges-Eugène Haussmann (Paris, 1809 - 1891): Prefeito entre 1853 e 1870 de um antigo departamento francês que incluía Paris, sendo responsável por sua reforma urbana, determinada por Napoleão III. Suas intervenções urbanísticas serviram de modelo para diversas cidades em escala global, pois permitia um melhor controle e vigilância das classes sociais sem ocupação e trabalhadora no espaço urbano.
} 
grande parte, pelo pleno aproveitamento da revolução técnico-ferroviária, acompanhando os traçados da linha férrea e tendo à frente o desenvolvimento dos trabalhos técnicos que agregavam e materializavam os conhecimentos no território, alterando a sua feição, sempre vinculados à produção e exportação cafeeira.

As estradas de ferro atendiam às conveniências dos fazendeiros, sem planos articulados entre elas e acompanhando a itinerância cafeeira. Tornavam-se sem função ou antieconômicas nos vários trechos onde a monocultura estava em declínio, afetando a constituição das cidades (MATOS, 1990).

Em 1800 poucas delimitações municipais existiam fora da região litorânea, do entorno da Capital e do vale do rio Paraíba do Sul, entre São Paulo e o Rio de Janeiro. Conforme as vias férreas avançavam, para beneficiar a economia cafeeira, ocorria o surgimento e desenvolvimento de cidades, segundo observamos nas representações cartográficas em uma composição de áreas aproximadas da divisão territorial daquela época (Figuras 4 e 5) em paralelo à evolução das principais ferrovias paulistas no século XIX, onde a cidade de Campinas, na metade do século XIX, constituía a capital agrícola de São Paulo, superando em muitos quesitos a própria Capital da Província. 
Figura 4 - Mapa da divisão político-administrativa do Estado de São Paulo em 1800 Escala aproximada: 1:7.200.000

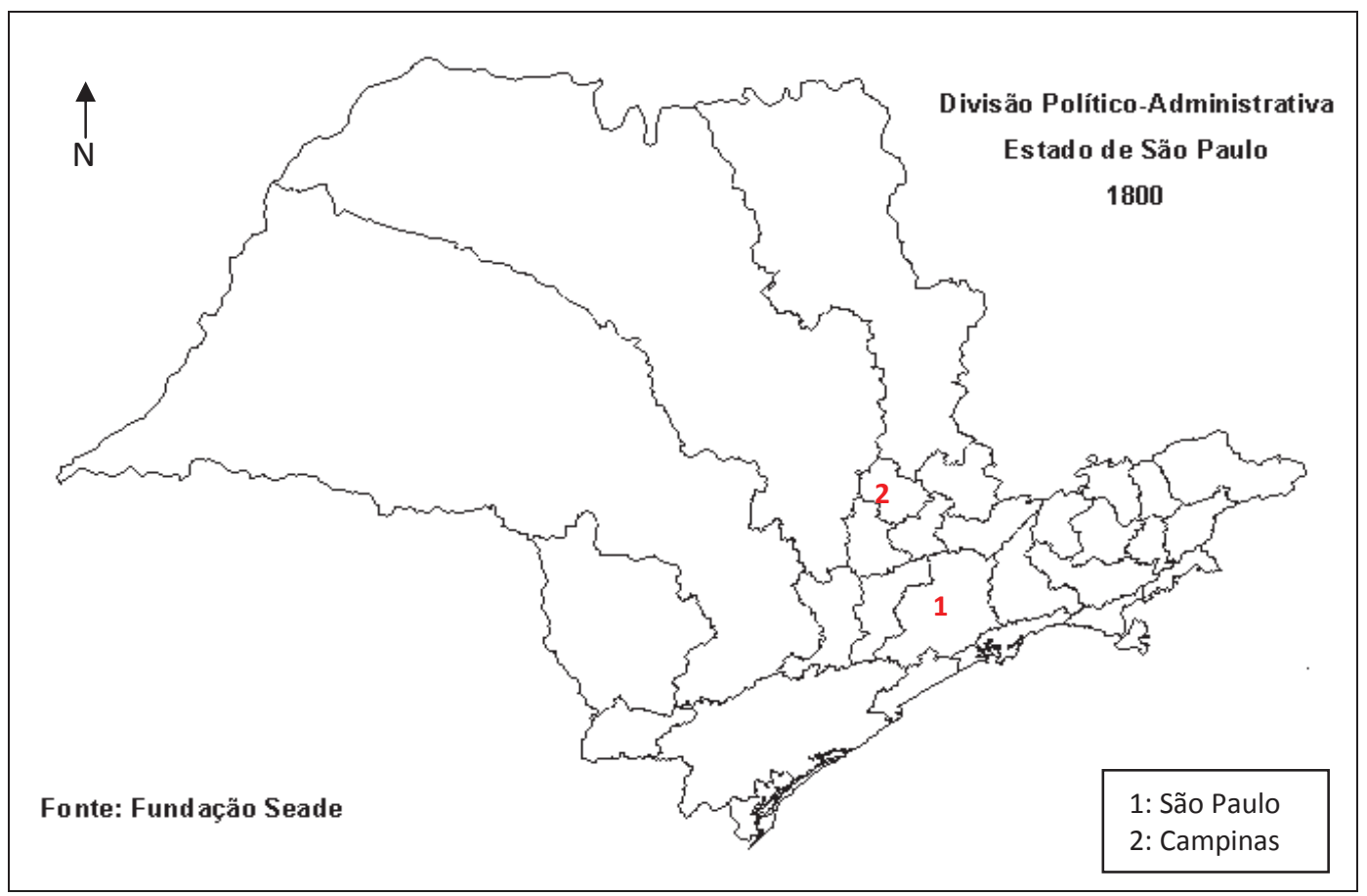

Fonte: SEADE (2016). Adaptação do autor (2018).

Figura 5 - Mapa da divisão político-administrativa do Estado de São Paulo em 1900 Escala aproximada: 1:7.200.000

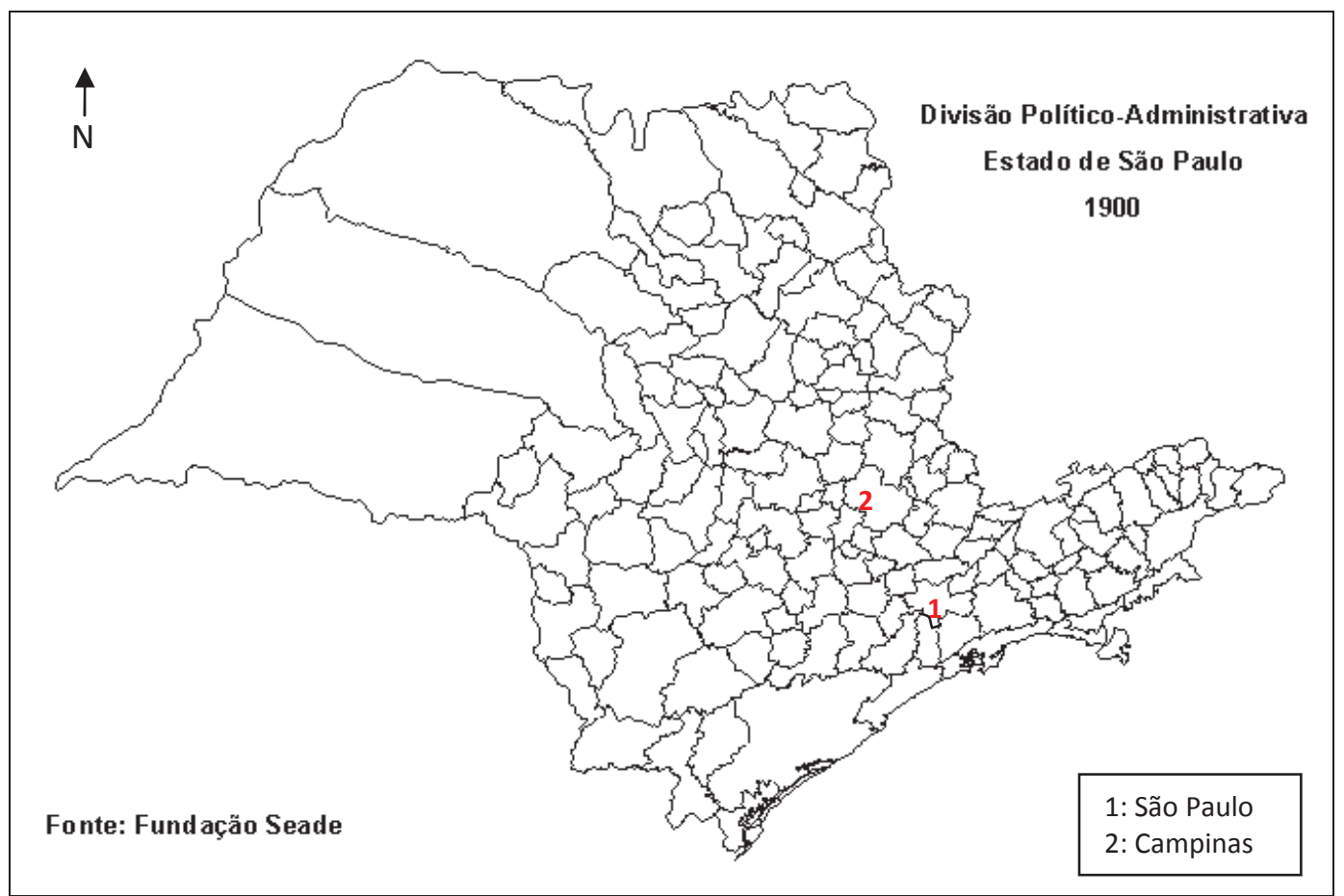

Fonte: SEADE (2016). Adaptação do autor (2018). 
Ricardi (2013) insiste quanto ao processo de urbanização, citando o seu impacto no ordenamento de São Paulo, que demandava por produtos e serviços, e observando o crescimento do número de municípios: de 46 em 1850, para 120 em 1886 e para 206 em 1920, acompanhando, de maneira mais proeminente, a expansão da fronteira agrícola para o oeste do Estado e os traçados das linhas ferroviárias que iam ocupando os espaços com baixa ocupação demográfica. Eram os chamados vazios demográficos.

Vale ressaltar, conforme Monbeig (1984, p. 113), que nenhuma nova unidade administrativa foi criada entre os anos de 1900 e 1910, em virtude do baixo afluxo populacional em áreas do interior, reflexo da desaceleração na produção cafeeira e de seu preço reduzido no mercado externo, posteriormente recuperado.

Nos mapas anteriores notamos o surgimento de diversos municípios propiciados pela instalação de ferrovias no território e graças ao sistema de plantation do café que, desde o final do Império, estava articulado com a construção e instalação das redes ferroviárias para o escoamento da produção cafeeira e para o abastecimento de mão de obra assalariada, em virtude da crise da escravidão.

As ferrovias também contribuíram para a regionalização de São Paulo, criando regiões conhecidas pelos nomes das linhas que as serviam, com exceções do litoral, o sul do Estado e o Vale do Paraíba (o antigo Norte), em virtude dessas áreas não terem seus territórios marcados pelas ferrovias (MATOS, 1990).

Assim se tem a zona Mogiana, a zona Paulista, a Araraquarense, a Noroeste e até zonas com especificações, como a Alta Paulista, Alta Sorocabana e assim em diante até preencher praticamente toda a representação espacial do território, como registrado no mapa (Figura 6). 
Figura 6 - As ferrovias na regionalização de São Paulo

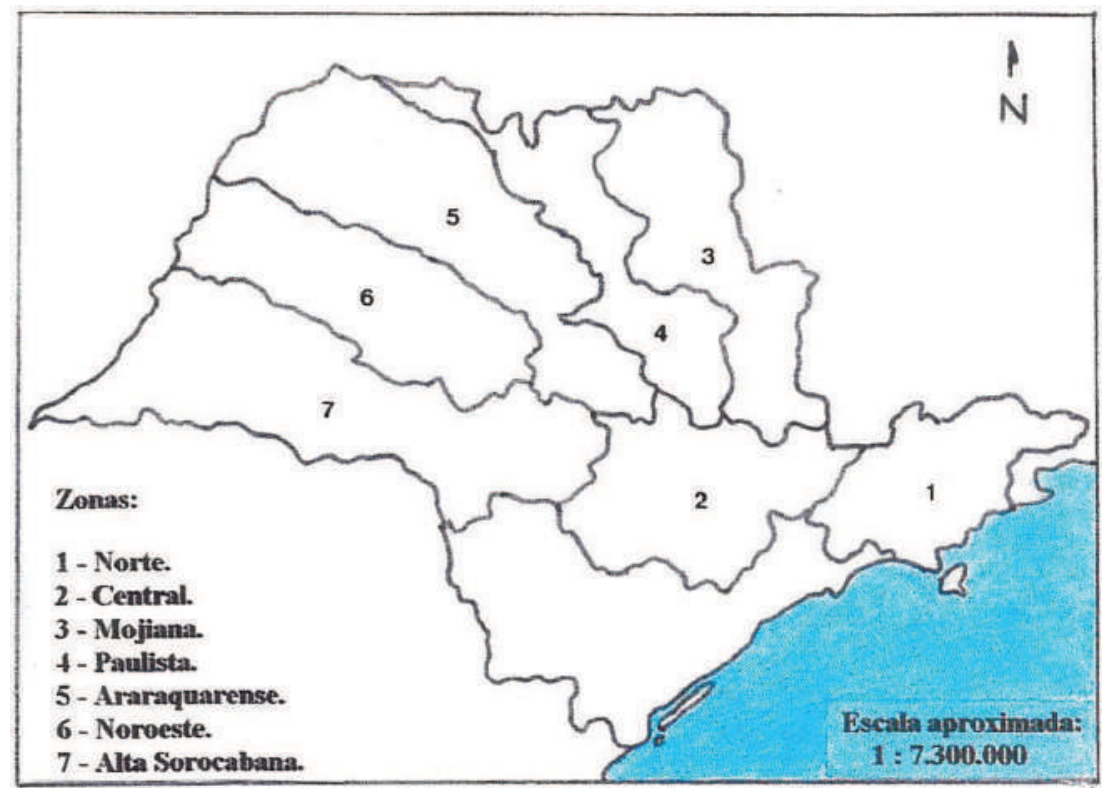

Fonte: Milliet (1982). Adaptação do autor (2017).

A partir da regionalização de São Paulo por meio de zonas de influência das linhas férreas, Milliet (1982) representou cartograficamente a evolução da penetração do cultivo cafeeiro em anos do século XIX, permitindo cartograficamente visualizar essa expansão, do Norte (vale do Paraíba) para o oeste.

Este fato faz-nos atentar para a importância das estradas de ferro na configuração espacial, com a formação de centros urbanos onde muitos fazendeiros passaram a residir e a exercer grande influência pessoal nas políticas locais e, em muitos casos, em escalas de maior abrangência.

O capitalismo na sua formação é determinado por um movimento de conjunto através da formação social que compreende uma estrutura produtiva e uma estrutura técnica. Segundo Santos (1977, p. 87), “trata-se de uma estrutura técnico-produtiva expressa geograficamente por uma certa distribuição da atividade de produção", reproduzindo uma ordem internacional na qual a cidade de São Paulo e região estavam inseridas.

Deve-se levar em consideração as características naturais de um lugar e a sobreposição de atributos conferidos a esse lugar, ambos possíveis de mudanças ao longo do tempo. Conforme Santos (1977, p. 91): 
O espaço reproduz a totalidade social, na medida em que essas transformações são determinadas por necessidades sociais, econômicas e políticas. Assim, o espaço reproduz-se, ele mesmo, no interior da totalidade, quando evolui em função do modo de produção e de seus momentos sucessivos. Mas o espaço influencia também a evolução de outras estruturas e, por isso, torna-se um componente fundamental da totalidade social

e de seus movimentos.

Com isso, pretendemos salientar que a paisagem de São Paulo e também de Santo Amaro, onde foi construída a represa, é criada e alterada a partir de diversos fatores que nela operam e faz parte de uma lógica de atuação internacional de inserção no modo de produção territorial vigente à época, com o capital cafeeiro, o transporte ferroviário, a reestruturação urbana, a imigração europeia e o desenvolvimento da atividade industrial, além da necessidade de produção e fornecimento de novas formas de energia para movimentar todo esse sistema que se agigantava e representava os principais elementos de efetivação do processo de modernização urbana, que marcou profundamente a paisagem da região.

\section{3 - São Paulo: o desenvolvimento da cidade}

Para entendermos as mudanças ocorridas na paisagem de São Paulo, fizemos um recorte têmporo-espacial, nos fixando em suas transformações durante o período de construção da represa Guarapiranga, de 1906 a 1909, no então município de Santo Amaro, fato que possibilitou maior produção de energia elétrica na Usina de Parnaíba e atendeu o seu principal mercado consumidor: a cidade de São Paulo. Essa produção energética foi seletiva de lugares e de grupos sociais, interferindo sobremaneira no modo de viver e de configurar a paisagem.

Para Rolnik (1988), São Paulo passou de uma cidade entreposto comercial de pouca importância no Brasil escravocrata para, em menos de trinta anos, vir a ser uma cidade de vanguarda na produção industrial do País. Esta passagem se produziu em um momento de transformações profundas na ordem social: passagem de um Estado Império escravocrata para a República do trabalho assalariado. Redefiniç̧ão essa que 
ocorreu por meio de transformação multidimensional, ou seja, mudaram enredos, palcos e personagens, as quais podem ser detectadas de várias formas:

[...] focalizando a atenção na transformação das relações econômicas ou sociais ou ainda nas instituições políticas. No entanto podemos também captá-la 'desmontando' o próprio espaço urbano, palco-personagem desta transição, uma vez que na geografia transformada da cidade está a marca da constituição da nova ordem social (ROLNIK, 1988, p. 75-76).

A cidade capitalista é gerada em meio a conflitos, onde seu espaço é política e socialmente diferenciado de acordo com os grupos sociais que nele habitam e interferem. Assim, "em uma cidade que cresceu radialmente, seguindo o desenho das ferrovias, o centro é região de distribuição de redes de transportes e de intensa circulação de indivíduos" e conferir-lhe um novo desenho significa ocupá-lo e marcá-lo peculiarmente (ROLNIK, 1988, p. 86).

O poder público teria delegado a política urbana e territorial da cidade, juntamente com a exploração dos serviços urbanos, às empresas privadas, que imprimiram sua lógica e racionalidade na exploração desses serviços, influenciando no modelo de expansão da própria cidade.

Quanto ao quadro natural da cidade de São Paulo, fundada entre os rios Tamanduateí e Anhangabaú, Azevedo (1945) em seus dizeres, quase poéticos, nos leva a contemplação imaginativa da região em que o autor descreve como formada por

[...] paisagem tranquila das colinas e altitudes modestas, recobertas por um tapete de relva ou de vegetação arbustiva, que vales numerosos modelam de forma suave e através dos quais correm sonolentos cursos d'água.

Em largos traços, é esta a paisagem dominante nos arrabaldes de São Paulo, como teria sido esta a que presenciaram os nossos antepassados, nos tempos recuados em que a pequenina cidade se encarapitava na colina central, entre o Tamanduateí e o Anhangabaú.

Entretanto, a singela beleza desse quadro natural esconde uma série de fatores negativos. Em primeiro lugar devemos citar a pobreza do solo, inteiramente impróprio para uma vida agrícola proveitosa [...] Em seguida é o clima cheio de variações, tão criticado [...], consequência de sua posição geográfica, situada não longe da escarpa do planalto. O relevo, enfim, com suas colinas, seus vales e suas várzeas inundáveis, a criar problemas para a expansão da cidade e para as comunicações. 
São Paulo surgiu, por conseguinte, em um sítio ingrato, onde uma série de fatores naturais, todos importantes, pareciam indicar que jamais um grande centro urbano poderia nele sobreviver e expandir-se. Assim aconteceu, realmente, durante três séculos (AZEVEDO, 1945, p. 17 e 19, itálico do autor).

A visão determinista do meio físico sobre o desenvolvimento humano de uma região não se aplicou em São Paulo, colocando-a entre "os mais expressivos exemplos das metrópoles tentaculares" do globo (AZEVEDO, 1945, p. 19). Até o final do século XIX a fisionomia da cidade pouco se alterou e os seus limites territoriais continuavam a ser praticamente os mesmos, enclausurada em um âmbito de não mais de um quilômetro de raio.

No mapa seguinte, (Figura 7), com escala que abrange Santo Amaro, observamos os círculos concêntricos, a partir do centro de São Paulo (Praça da Sé) e sua expansão. Inicialmente vemos a mancha urbana e seu limite até 1874 (representada em preto); o perímetro urbano se expande e há uma nova e maior configuração em 1890 (graficamente representado pelos quadriculados) e finalmente percebemos a área urbanizada na metade do século XX (representada pelo hachurado do mapa). 
Figura 7 - O desenvolvimento da mancha urbana da cidade de São Paulo, até metade do século XX

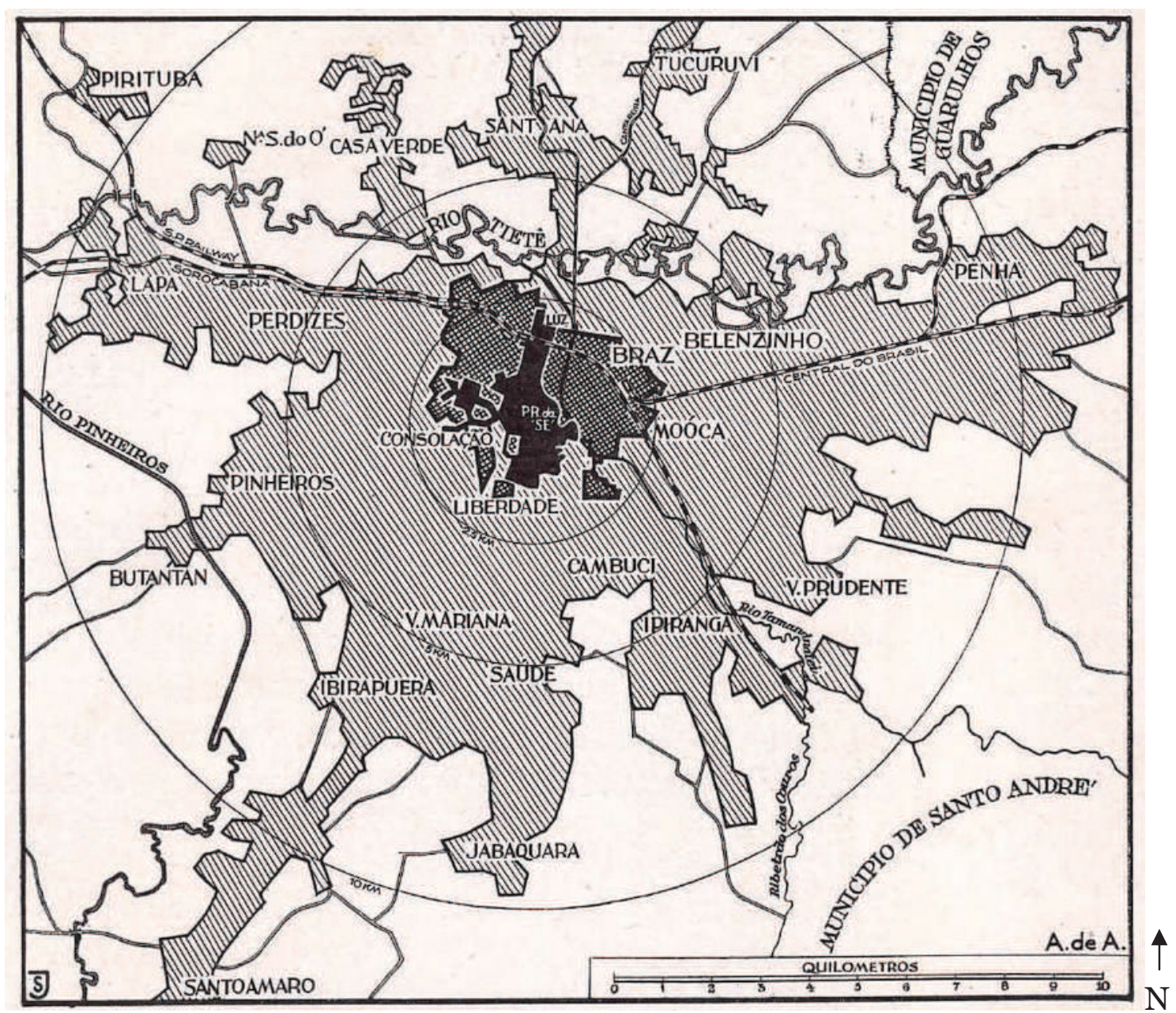

Fonte: Azevedo (1958, p. 27). Adaptação do autor (2018).

Vários foram os fatores que propiciaram o desenvolvimento econômico e alargamento da Capital, como os já destacados anteriormente, assim, foram as razões de ordem humana que se sobrepuseram aos fatores pouco favoráveis ao sítio urbano. Porém, os fatores de ordem física também contribuíram para a expansão da cidade e favoreceram a atuação humana, a qual se destaca a fisiografia, onde a posição geográfica "[...] em contacto difícil, mas não impossível com o litoral, sem nenhuma grande barreira a isolá-la do interior, em relação ao qual, ao contrário, dispõe de vias naturais, utilizadas tanto outrora como hoje" (AZEVEDO, 1945, p. 29).

A visão de Azevedo (1945) pareceu-nos, a princípio, determinista, mas a compreendemos como uma sinalização importante em se considerar o espaço físico e 
seus elementos naturais como componentes na transformação e adaptação desse espaço pelo homem, o qual transformou-o substancialmente.

Hobsbawm (1998) insiste que as atividades econômicas promovem intensas articulações nas finanças estabelecidas em rede e o fato de maior relevância do século XIX foi a criação de uma economia global, que atinge progressivamente as mais remotas localidades do globo, em "uma rede cada vez mais densa de transações econômicas, comunicações e movimentos de bens, dinheiro e pessoas ligando os países desenvolvidos entre si e ao mundo não desenvolvido", embora essa globalização econômica não seja nova, teve seu desenvolvimento acelerado "[...] mais maciçamente em termos de volume e cifras - entre 1875 e 1914” (HOBSBAWM, 1998, p. 95).

No caso do Brasil, "as inversões ocorriam de fora para dentro, por meio de capitais estrangeiros e em função da integração de suas economias agroexportadoras na nova divisão internacional do trabalho [...]", sendo que na cidade de São Paulo "os investimentos estavam ligados à infraestrutura de serviços, essenciais para o incremento da produção e circulação de mercadorias" (CARVALHO, 2003, p. 29).

A instalação da Light em São Paulo representou o maior investimento realizado pelo Canadá no exterior, somente possível graças aos movimentos e poder político local, criando um quadro institucional favorável para uma maior integração do Brasil na economia mundial e no caso específico de São Paulo, o prefeito Antônio Prado teve um importante papel nesse processo de integração, em particular, nos investimentos em infraestrutura urbana.

Em meados da década de 1860 o prefeito fez uma viagem à Europa, decisiva para implementar modificações na Capital e segundo o relato de Carvalho (2003), o então prefeito

já era um grande plantador de café e um dos homens mais ricos e influentes do Brasil desde os tempos do Império, em sua viagem estreita os laços com as companhias exportadoras de café, como a Brazilian Warrant Company, tornando-se muito mais que um simples plantador de café, diversificando suas atividades em áreas como o comércio exportador, setor bancário e indústria. Chamou-lhe atenção também o progressivo poder da tecnologia nos empreendimentos comerciais bem como nas transformações urbanas [...] Por isso, talvez não seja um mero acaso que o início das atividades da Light em 1899 coincida com o primeiro ano de sua longa gestão à frente da prefeitura de São Paulo (CARVALHO, 2003, p. 29-30). 
A administração dos municípios, tanto na Colônia como no Império, era feita pelas Câmaras de Vereadores, com frequente interferência dos governadores da capitania, na Colônia, ou dos presidentes da província, no Império. A Constituição Republicana de 1891 instaurou o federalismo no país, com o que os Estados ganharam poderes antes exclusivos do governo central, inclusive o de legislar sobre o modo de administração dos municípios. "A instabilidade política e institucional era a marca da administração municipal, inclusive como reflexo das turbulências que se sucediam no plano nacional." Enfim, “em novembro de 1898, foi aprovada a lei municipal $n^{\circ} 374$, criando os cargos de prefeito e vice-prefeito, a serem escolhidos pelos vereadores entre seus pares". Apenas por um hiato, durante o período regencial até a proclamação da República, o cargo de prefeito inexistiu no Brasil (TOLEDO, 2015, p. 25-26).

Em São Paulo, coube ao Conselheiro Antônio Prado, título esse de Conselheiro conferido por D. Pedro II aos membros do Conselho do Império e que se manteve mesmo após a Proclamação da República, ser escolhido pelos seus pares vereadores, em 1899, como o primeiro prefeito de São Paulo ${ }^{13}$.

O Conselheiro formulou e impôs novos ritmos de apropriação do espaço urbano, sendo que à época não se empregava o vocábulo urbanismo no Brasil, falava-se em melhoramentos e embelezamentos, nos quais se destacavam os engenheiros-arquitetos, como estudiosos e atuantes do urbano. Pela primeira vez procurava-se dar um caráter técnico ao planejamento da cidade, que nascera com ruas sinuosas e desalinhadas, típicas de um tecido urbano desenvolvido de acordo com as circunstâncias (TOLEDO, 2015, p. 31 e 60).

Os avanços técnicos impostos ao espaço representam, conforme Custódio (2012, p. 67), uma libertação de imperativos naturais, constituindo, em nosso ver, um domínio da razão humana materializada, no qual os engenheiros tiveram uma atuação importante para a apropriação dos espaços pela técnica, transformando-os para as novas adequações do tempo histórico ${ }^{14}$.

O centro da cidade era formado por três ruas principais que circundavam o topo da colina e ligavam os mosteiros do Carmo, de São Francisco e de São Bento, chamado

\footnotetext{
13 Antônio da Silva Prado (São Paulo, 1840 - Rio de Janeiro, 1929) - Três vezes eleito pela Câmara Municipal como Prefeito e uma vez por eleição direta.

14 A produção de imagens como desenhos, croquis e fotografias também foram desenvolvidas e promovidas pela engenharia, no contexto das atividades práticas.
} 
de triângulo ${ }^{15}$. Por volta de 1820 o centro da cidade compunha-se de poucas ruas, sem ordenação e com espaços vazios entre si. "Dos edifícios públicos, nenhum era suntuoso ou dotado da elegante fachada barroca notória em terras ibéricas" (MORSE, 1970, p. 44).

Embora predominasse a atividade agroexportadora dos grandes cafeicultores na economia e na sociedade cafeeira paulista no início da República, conforme nos relata a historiografia mais tradicional, percebe-se que alguns cafeicultores diversificavam as suas atividades e, ao analisar as iniciativas de Antônio Prado, notamos que ele passou também a atuar no comércio exterior, no setor bancário e na indústria, desconstruindo a suposta visão de uma elite monolítica e sem conflitos. Assim, a presença e influência cada vez maior dos capitais estrangeiros no país não devem ser compreendidas simplesmente como resultado de simples imposição externa, mas como "o resultado complexo de mecanismos econômicos que articulavam a economia brasileira no mercado mundial" (CARVALHO, 2003, p. 31).

Esse fato pode ser verificado também nas relações estabelecidas entre a Light e as esferas de poder político nas diversas instâncias, significando importantes vantagens econômicas e jurídicas para a companhia.

Foi durante a gestão do prefeito Antônio Prado (1899-1911) que se iniciam as intervenções urbanísticas mais intensas, a qual

transferiu mercados das zonas centrais para os subúrbios, alargou ruas do centro velho, remodelou praças. Estas mudanças implicaram o deslocamento das populações que ali habitavam ou circulavam.

[...] do ponto de vista político, esta operação pode ser lida também como redistribuição de territórios, redefinição da hierarquia da segregação espacial. [...] os limites e configurações das zonas da cidade se redefinem continuamente, as transações mercantis que envolvem o solo urbano são particularmente intensas em conjunturas de crescimento acelerado. No entanto, os projetos de reforma urbana marcam um momento especial neste redefinir contínuo: são ações que implicam vultosos investimentos, envolvendo grande número de proprietários, quantidade maior ainda de usuários e ocupantes do espaço/objeto de intervenção (ROLNIK, 1988, p. 84-85).

\footnotetext{
${ }^{15} \mathrm{Em} 1873$, as ruas que formavam o triângulo central receberam os primeiros paralelepípedos de granito e constituíam o padrão de muitas ruas. O asfalto foi usado pela primeira vez na Avenida Paulista, no final da primeira década do século XX (MORSE, 1970).
} 
Também nos primeiros anos do século XX, iniciou-se em São Paulo um processo de transformação e inovação tecnológicas que iriam fazer parte do cotidiano das pessoas. "A cidade paulatinamente começa a se ver mergulhada em novos ritmos os quais, por sua vez, estão relacionados com a criação e o estabelecimento de um novo conceito de tempo" (CARVALHO, 2003, p. 76).

No período em que se construía a represa Guarapiranga, Antônio Prado, como prefeito de São Paulo, sempre procurava expor a sua figura para grande parte da população. Sevcenko (1992) faz observações sobre a atuação do prefeito frente à administração, relatando a sua atitude em se mostrar nos mais variados espaços públicos, para servir de modelo de como se portar adequada e elegantemente nos lugares que ele pretendia divulgar e inaugurar.

O prefeito fez muitas obras na cidade e dispunha de prestígio perante uma população ávida por melhorias, mas a sua atuação se resumia a parcelas da urbe e a determinados segmentos sociais e, ainda, "investir na criação de uma urbe moderna de padrão europeu implicaria também, como contrapartida, instigar a população a ocupá-la convenientemente e aprender a desfrutar de suas amenidades [...]" (SEVCENKO, 1992, p. 122).

A construção do teatro municipal, de 1808 a 1911, foi outra obra em sua gestão que vai ao encontro dos seus ideais na construção do espaço público. Encomendou o projeto ao próprio arquiteto da sua família e, após concluído, era maior e mais ostensivo que o da Capital Federal, inaugurado em 1909.

Nesse movimento de transformação espacial o prefeito também enfrentou uma grande contenda pública com a Light, onde a ação especulativa da companhia renegava a cidade e a cidadania à população e conforme excerto de Sevcenko (1992), a Light era um grande agente que comprometia

definitivamente o futuro da cidade, forçando seu desenvolvimento em bolsões desconexos, espaços discriminados, fluxos saturados e um pavoroso cemitério esparramado de postes e feixes de fios pendurados como varais por toda a área urbana, foi o monopólio do fornecimento de gás, eletricidade, transportes urbanos, telefones e mais tarde de água [...] Esse monopólio simultâneo dos serviços mais essenciais dotara a empresa do poder de manipular o mercado de valorização do solo urbano, de forçar associações com particulares em manobras especulativas e eventualmente de corromper autoridades e instituições, como é fácil de se imaginar e em nenhum instante escapou à percepção da 
população ou da imprensa de linha mais crítica. O fato é que, quando da renovação do contrato monopolista da Light em 1909, o conselheiro Antônio Prado deu parecer contrário e, mesmo incitado por generoso suborno [...]

Essa decisão foi festejada como uma vitória pela população, oprimida pela especulação de terrenos e preços de aluguéis provocados pelas manobras da Light, além das tarifas extorsivas e péssimos serviços das companhias de eletricidade, gás, bondes e telefones. Mas um mês depois, a Comissão de Justiça da Câmara dos Vereadores reverteu a situação, dando parecer favorável e reconfirmando o monopólio. A resposta foi um motim popular de grandes proporções, com a ocupação do Triângulo [...] pelos estudantes e populares, forçando a ocupação militar dos escritórios da Light e do jornal a ela filiado, A Gazeta. Na sequência dos eventos, a população enfrentou os soldados a pedras, paus, frutas, legumes e bombas artesanais, sofrendo cargas violentas, espancamento brutal e prisões indiscriminadas [...]

Mas a vitória final foi da Light e da especulação (SEVCENKO, 1992, p. 122-123, itálico do autor).

Desde a segunda metade do século XIX o avanço de novas atividades, genericamente nomeadas de serviços urbanos, como as empresas voltadas ao transporte público, à iluminação (a gás) das ruas, aos serviços de água e esgoto e de telefones existiam na urbe, mas no final do século XIX e os primeiros anos de século XX "apresentaram rápido movimento de expansão desses serviços e mudanças significativas, em boa parte relacionados com o capital estrangeiro". No entanto, quanto às cidades do interior, alguns desses serviços foram estabelecidos por meio de empresas locais. Já em São Paulo, houve a tendência à formação de empresas de maior porte e à penetração do capital estrangeiro nesses setores (SAES, 1986, p. 143-144).

Percebe-se, também, a forte relação da Capital com as linhas férreas que a cortavam, servindo como centro do transporte ferroviário e possibilitando à cidade uma vida econômica de múltiplas dimensões. No final do século XIX, havia três linhas ferroviárias que tinham seu ponto inicial na cidade ou a cruzavam: a ferrovia SantosJundiaí, operada pela The São Paulo Railway Co., que atravessava a Capital, no bairro da Luz, com uma estação modesta, anterior à atual, mas no mesmo local; a Estrada de Ferro Sorocabana que partia para o interior e localizava-se próxima à Luz " [...] a fim de facilitar a transferência das mercadorias dos trens da Sorocabana para os da São Paulo Railway”; e os trens da Companhia Estrada de Ferro São Paulo - Rio de Janeiro, que mais tarde seria incorporada à Central do Brasil e saíam da Estação do Norte, no Brás, 
em direção a Cruzeiro (Vale do Paraíba), para fazer a conexão com a Estrada de Ferro D. Pedro II rumo ao Rio de Janeiro (SAES, 2004, p. 216).

Embora essas estradas tivessem a construção motivada pelo comércio do café, sua presença na cidade gerou e estimulou novas atividades, criando "a primeira categoria de trabalhadores urbanos assalariados [ferroviários] de grande expressão (cuja subsistência demandava alimentos, vestuário, mobiliário, habitação etc)" (SAES, 2004, p. 216-217). As estradas de ferro representavam para a cidade um permanente impulso em suas atividades econômicas, tanto direta como indiretamente, pelos salários de trabalhadores de estações, armazéns, oficinas e escritórios.

A infraestrutura ferroviária trouxe vantagens operacionais ao concentrar todo o escoamento da produção por intermédio de um único centro articulador (cidade de São Paulo) e um único porto exportador (Santos). Dessa forma, cerca de $70 \%$ do volume do mercado mundial de café estaria concentrado em um único ponto, facilitando a manipulação de um mercado extraordinário e a especulação em torno desse centro de articulação (SEVCENKO, 1992, p. 108).

A cidade de Santos nunca teve em sua órbita mais que algumas cidades da planície litorânea, ao passo que São Paulo dominou estrategicamente as rotas terrestres e fluviais da região constituindo-se em um ponto de distribuição para uma ampla região interiorana. Embora de tempos em tempos algumas passagens através da Serra do Mar tenham atraído algum tráfego, todas se limitaram a ter importância local ou temporária, salvo a rota São Paulo-Santos que, tanto na era do burro de carga como na locomotiva, foi a artéria principal do planalto (MORSE, 1970, p. 39).

No entanto, um fator preponderante na alteração do espaço de São Paulo está na produção e fornecimento de energia elétrica em grande escala. Essa transformação tecnológica promoveu grande impacto na virada do século XIX para o XX e está intimamente ligada à construção da represa Guarapiranga para o fornecimento e funcionamento da hidrelétrica no rio Tietê, em Parnaíba.

A produção de eletricidade já ocorria na segunda metade do século XIX, quando em 1886 foi organizada a Empresa Paulista de Eletricidade, subordinada à firma Marques, Moutte \& Comp., que se propunha a iluminar residências e lojas. Tais serviços exigiam investimentos vultosos e a empresa foi absorvida por uma de maior porte: a Companhia de Águas e Luz do Estado de São Paulo, de capital nacional, e que 
explorava a produção e distribuição de energia elétrica, gerada por uma pequena usina a vapor localizada no centro da cidade.

Nesse período, a energia elétrica estava circunscrita à algumas indústrias, na maioria das vezes com geradores próprios e a iluminação pública dava seus primeiros passos em algumas cidades, mas o crescimento esbarrava tanto nas condições técnicas como na concorrência com o gás (SILVA, 2008, p. 33-34).

Foi com a eletricidade que se iniciou o estabelecimento de uma rede de serviços urbanos mais dinâmicos, somente viabilizada economicamente por meio de grandes investimentos na exploração que possibilitava, em contrapartida, grandes lucros. No final do século XIX e início do XX, boa parte da expansão dos capitais estrangeiros investidos em serviços urbanos de utilidade pública ocorreu no ramo da energia elétrica, com companhias de grande porte controladas por grupos financeiros estrangeiros (SILVA, 2008), tanto que, em 1880,

o capital britânico investido na América Latina era de 179 milhões de libras, dos quais 38,8 milhões só no Brasil. No caso da The San Paulo Gas Company, o investimento era totalmente britânico. $\mathrm{Na}$ área de serviços urbanos foi a primeira experiência em grande escala neste setor. No caso do grupo Light, a escolha do Canadá como base para a sua incorporação se deveu ao acesso privilegiado que poderiam ter ao mercado financeiro britânico. Apesar de integrar o império britânico, o Canadá possuía leis menos rígidas, o que facilitaria o empreendimento (SILVA, 2008, p. 36).

Em 1899, a administração municipal editava a Lei $n^{\circ} .497$ que regulava o serviço de distribuição de eletricidade e "uma das novidades apresentadas era o assentamento de postes para as fiações" que muito transformou a paisagem (SILVA, 2008, p. 89).

A cidade expandiu-se seguindo a lógica de grupos privados que definiam a orientação dos eixos de expansão conforme seus próprios interesses. Tal fato proporcionou um crescimento extenso e segmentado, sendo explorado pelo desenvolvimento de infraestruturas urbanas a cargo de grandes empresas privadas, sempre de comum acordo com a administração pública, determinando o modelo de configuração da paisagem e gerando áreas valorizadas e vazios que se tornavam alvo de especulação. Assim, a Light lucrava na exploração dos serviços urbanos, seguindo este 
padrão específico de urbanização de crescimento aparentemente desordenado e usando suas concessões de monopólio dos serviços públicos.

A Light custeava desapropriações de áreas que julgasse necessárias para suas atividades, sendo muitas vezes esses terrenos utilizados como mera reserva de valor para a empresa, onde nos vazios iam surgindo novos loteamentos que necessitavam de abastecimento de serviços urbanos. Esse processo especulativo mudou profundamente a paisagem urbana e muitas vezes, ainda, a Light atendia diretamente aos pedidos de especuladores imobiliários, como o caso da Companhia City, responsável por grandes empreendimentos imobiliários e de urbanização de diversos bairros da Capital $^{16}$.

Com base nos relatórios da Light, Silva (2008) fez uma tabela do consumo de energia na cidade de São Paulo, a qual reproduzimos parcialmente a seguir (Tabela 2):

Tabela 2 - Consumo de energia elétrica na cidade de São Paulo fornecida pela The São Paulo Tramway, Light and Power Co. Ltd.

\begin{tabular}{|c|c|c|c|c|}
\hline Ano & $\begin{array}{l}\text { Consumidor de } \\
\text { energia }\end{array}$ & $\begin{array}{l}\text { Consumidor de } \\
\text { iluminação }\end{array}$ & $\begin{array}{l}\text { Consumidores } \\
\text { (ligação) }\end{array}$ & $\begin{array}{l}\text { População da } \\
\text { cidade de } \\
\text { São Paulo }\end{array}$ \\
\hline 1901 & - & 1343 & 1045 & 239.820 \\
\hline 1902 & 86 & 3334 & 3420 & \\
\hline 1903 & 151 & 4189 & 4340 & \\
\hline 1904 & 188 & 4025 & 4213 & \\
\hline 1905 & 220 & 3966 & 4186 & \\
\hline 1906 & 245 & 3926 & 4171 & \\
\hline 1907 & 310 & 3983 & 4293 & \\
\hline 1908 & 361 & 4209 & 4570 & \\
\hline 1909 & 428 & 4727 & 5155 & \\
\hline 1910 & 535 & 5343 & 5878 & 375.439 \\
\hline 1911 & 737 & 6196 & 6933 & \\
\hline 1912 & 1045 & 8245 & 9290 & \\
\hline 1913 & 1271 & 12148 & 13419 & \\
\hline 1914 & 1321 & 16386 & 17707 & \\
\hline 1915 & 1439 & 22414 & 23853 & \\
\hline 1916 & 1494 & 28757 & 30251 & \\
\hline 1917 & 1604 & 34084 & 35688 & \\
\hline 1918 & 1695 & 40712 & 42407 & \\
\hline 1919 & 1834 & 45129 & 46963 & \\
\hline 1920 & 2129 & 49219 & 51348 & 587.072 \\
\hline
\end{tabular}

Fonte: Silva (2008, p. 47). Adaptação do autor (2018).

${ }^{16}$ A Companhia City - City of São Paulo Improvements and Freehold Land Company Limited - foi fundada em 1912 e urbanizou bairros de São Paulo, como o Jardim América, Pacaembu, Alto da Lapa e Pinheiros (SILVA, 2008). 
Conforme a análise do autor sobre a tabela estatística do consumo de energia elétrica na cidade e os anos iniciais do século XX, concluiu-se que,

[...] o fornecimento de eletricidade distinguia-se em luz (iluminação) e força (força motriz para equipamentos industriais e residenciais) [...] podemos perceber que desde o início das atividades da empresa [Light] o consumo maior era de iluminação. Mas o crescimento do consumo de energia era constante e teve um aumento em 1912 devido aos aparelhos domésticos e motores industriais. Se em 1902 o uso de energia para força motriz representava apenas 2,5\% do total, em 1912 chegava a cerca de $11 \%$.

A iluminação, no entanto, teve um crescimento lento, devido a deficiências técnicas e entraves jurídicos (concorrência com o gás), apenas resolvidos com a introdução de um novo modelo de lâmpadas incandescentes em 1910 e com a aquisição da Companhia de gás em 1912 (SILVA, 2008, p. 46).

Segundo, ainda, Silva (2008) e Souza (1982), havia entre a população da época certa desconfiança em relação à luz elétrica. Muitas pessoas achavam que a luz fazia mal aos olhos, não era segura, liberava fuligem e poderia cheirar mal. Estrategicamente a Light no início comercializava produtos elétricos, na tentativa de disseminar o seu uso e o consumo energético.

Contudo, verificamos que alguns melhoramentos urbanos já estavam presentes no fim do Império, fato justificado mais pelo desenvolvimento econômico da cidade do que pelo quantitativo da sua população, como a iluminação a gás fornecida pela empresa inglesa The São Paulo Gas Company Ltd., que desde 1872 vinha substituindo os antigos lampiões; o transporte urbano que contava desde esse mesmo ano (1872) com os bondes de tração animal puxados por burros; a captação e distribuição de água, por meio de tubulações de ferros, para parte da cidade iniciada em 1883 pela Companhia Cantareira de Esgotos, salientando que os dejetos captados pelo esgoto eram lançados no rio Tietê, a principal artéria fluvial da cidade e uma nova usina de produção de gás, na rua do Gasômetro, no Brás, substituiria a original que fora demolida, em 1910 (SAES, 2004, p, 217).

As chamadas comodidades modernas da época, tais como a eletricidade, esgoto canalizado, água potável, pavimentação, limpeza pública e arborização eram privilégios de uma ínfima parcela da população. Durante toda a República Velha, os critérios para a implantação dos serviços de infraestrutura em São Paulo não estavam relacionados com 
a quantidade de usuários em cada bairro, mas sim, com os lucros gerados nos negócios ou com a capacidade de pagamento dos consumidores desses serviços. Dessa forma, os bairros operários eram os mais atingidos pela escassez das comodidades e, portanto, a oferta de infraestrutura não tinha relação direta com a densidade demográfica de regiões da cidade e sim com o aproveitamento econômico que se poderia auferir deles (CARVALHO, 2003, p. 22).

\section{4 - Santo Amaro: a cidade e a represa}

Para a compreensão da formação da represa Guarapiranga e do desenvolvimento de Santo Amaro, teremos que entender os trâmites pelos quais passava a cidade de São Paulo, a Capital da então Província e de destaque para a região.

Em meados do século XIX a cidade de São Paulo vivia em equilíbrio simbiótico com a região circunvizinha, "era então ainda a cidade rural, colonial" (MORSE, 1970 p. 165) e não apresentou aumento considerável de população. "A maioria das fontes, quaisquer que seja a data a que se refiram durante esse período, acusam de 20.000 a 25.000 habitantes" (MORSE, 1970, p. 171)

Na Província de São Paulo, no início do século XIX, o trabalho agrícola baseava-se na escravidão africana, o sistema de crédito e o fluxo de capitais eram insuficientes para implementar novos investimentos a muitos fazendeiros. A esses fatos aliavam-se carentes vias de comunicação e de bons mercados consumidores em uma Província pobre que não atraia pessoas (MILLIET, 1982).

Apesar de uma população ainda pequena, observa-se que a cidade de São Paulo crescera muito rapidamente entre 1872 e 1890, ostentando uma significativa diversificação econômica, fruto da renda gerada pela atividade cafeeira.

A cidade, segundo Souza (1982), possuía cerca de 20 mil habitantes em 1872, ocupando a décima posição em quantitativo populacional, sendo superada pelo Rio de Janeiro, Salvador, Recife, Belém, Niterói, Porto Alegre, Fortaleza, Cuiabá e São Luís e com a indústria pouco desenvolvida.

Em 1886, a Comissão Central de Estatística de São Paulo, estimava em 47.697 habitantes e em 1890 registrava um número superior a 64.934 habitantes, sendo neste 
ano, a quarta capital mais populosa do Brasil. Era superada pelo Rio de Janeiro com mais de 522 mil habitantes, por Salvador com 174 mil e por Recife com 111 mil (SAES, 2004, p. 216).

Quanto a Santo Amaro, o município contava em 1886 com 6.259 habitantes e em 1900 passou a contar com 7.132 habitantes, conforme pesquisa de Peralta (2017, p. 197), mostrando dessa forma, para o ano de 1886, uma população aproximadamente oito vezes inferior à da Capital. Santo Amaro não acompanhou proporcionalmente esse ritmo. Contudo, Santo Amaro na década de 1920, contava com uma população de aproximadamente 14 mil habitantes, a qual, em torno de 9\% dessa totalidade era composta por imigrantes (PERALTA, 2017, p. 346).

A transformação de São Paulo em um centro urbano importante no comércio do café propiciou um grande volume de investimentos capitalistas que alteraram drasticamente o antigo povoado. A cidade se desenvolveu com o processo de importação de capitais e exploração de serviços urbanos, sobretudo com a chegada de grupos estrangeiros como a The San Paulo Gas Company (1872) e a The São Paulo Tramway, Light and Power Company (1899), as quais faziam parte de um processo global de procura por novos mercados, atuando na exploração de serviços urbanos em grande escala (SILVA, 2008, p. 20).

A construção da represa Guarapiranga estava inserida neste contexto globalizante e modernizador por qual passava a cidade. A represa tinha por finalidade regularizar a vazão das águas e movimentar turbinas para a produção hidrelétrica na usina localizada no rio Tietê, a jusante da Guarapiranga, e, embora ela pertencesse ao então município de Santo Amaro, e a usina à Parnaíba, tinham em São Paulo o seu centro de poder radiador, em uma escala regional de decisões.

Paralelamente ao aumento da população, surgiam o crescimento e a diversificação das atividades econômicas que, se em um primeiro momento o café foi o principal responsável por todo esse crescimento, com o tempo a cidade tornou-se um centro urbano com dinâmica própria, atraindo e implementando atividades urbanas de transportes, energia elétrica, comércio, bancos e indústrias. Este desenvolvimento urbano foi o responsável por aliciar grandes empresas estrangeiras. O poder público levou a cabo o papel de fomentador e concessionário das atividades urbanas promovidas por essas grandes companhias então constituídas (SILVA, 2008, p. 20-21). 
Em Santo Amaro observamos que suas terras, no início, pertenciam administrativamente à Freguesia de São Paulo. Em 1832 foi elevada à Vila e tornou-se um município independente. Somente em 1935 torna-se mais uma vez parte territorial e administrativa da Capital paulista.

A ocupação de Santo Amaro, localizado ao sul de São Paulo, remonta ao período anterior à colonização portuguesa no Brasil, originando-se do aldeamento dos índios guaianases, à beira do rio Jeribatiba ${ }^{17}$, atual rio Pinheiros, na localidade do Ibirapuera, base da futura cidade de Santo Amaro (BERARDI, 1981) ${ }^{18}$.

A região de Santo Amaro inicialmente foi constituída de um território na margem esquerda do rio Jurubatuba por terras doadas aos jesuítas em 1560, pelo Capitão Francisco de Morais e era constituída por um

relevo brando, com lindas e extensas campinas. O Morro da Barra, no fim de uma cadeia de colinas, estava bem na confluência dos rios Jurubatura (ou Geribatiba) e Guarapiranga. Nas várzeas destes rios havia matas cerradas, que em alguns pontos mais afastados tomavam o aspecto de sertão bravio. Os dois cursos d'água, agora unidos, iam até o Rio Pinheiros, numa planície, e pelo Pinheiros alcançava-se o Tietê (BERARDI, 1981, p. 24).

$\mathrm{Na}$ região também havia criadores de gado e esse núcleo de povoação mais sólido instalado facilitou a afluição de novos moradores. Após a Proclamação da Independência política do Brasil (1822), o então imperador D. Pedro I (1798-1834) procurou obter na Europa soldados que pudessem lutar nas guerras do sul do Brasil, além de trazer colonos para o país. Aliciou-se diversas pessoas, sobretudo da Baviera

\footnotetext{
${ }^{17}$ Rio Jeribatiba ou Jurubatuba. A denominação varia de acordo com a fonte pesquisada, mas o termo jurubatuba é o que prevalece atualmente, significando, na língua tupi, jerivá - palmeira que produz cocos e tiba - abundância.

${ }^{18}$ A toponímia oficial da região originou-se em 1686, quando o Bispo do Rio de Janeiro, D. José E. Barros Alarcão, confirmou a capela curada em Ibirapuera, distrito de São Paulo, elevando o seu povoado à categoria de freguesia, com o nome de Santo Amaro. Por muito tempo a região ficou conhecida por diversos nomes indígenas, como: "Birapuera, Virapuera, Ibirapuera, Geribatiba, Geribativa, Jeribatiba, Santo Amaro de Virapuera, Santo Amaro de Ibirapuera; até que tomasse definitivamente o nome de Santo Amaro", conforme verificado na página virtual sobre a história dos bairros da Prefeitura de São Paulo (2016).

Berardi (1981, p. 31) também corrobora essa hipótese e relata uma possível troca das letras "v" por "b" nas grafias dos registros dos escrivães portugueses, consolidando assim, a pronúncia dos topônimos.
} 
(Alemanha), "prometendo riquezas, honrarias, altos cargos, terras próprias" (BERARDI, 1981, p. 53).

Mas foi durante a conjuntura política do período regencial $(1831$ - 1840), quando "[...] em 1832 Santo Amaro, uma Freguesia de São Paulo com cerca de 2.000 habitantes, foi elevada a Vila”, mediante Decreto Regencial de 10 de julho de 1832 (PERALTA, 2017, p. 12).

Provavelmente pelo fato de Santo Amaro estar localizada fora das áreas produtoras de café, com solo considerado pobre para a grande lavoura comercial e com muitas áreas de várzeas, é que tenha desempenhado uma função marcada pela coleta e comercialização de lenha (carvão), madeira e pedra para construção, além da produção de gêneros alimentícios de primeira necessidade.

Mesmo com o solo desfavorável, a agricultura sempre se manteve, servindo para a simples subsistência, ao passo que em outras partes contribuiu, embora em extensão limitada, para abastecer a cidade. A ação das enxurradas também "favorecia o desaparecimento do solo vegetal, sobretudo nos pontos mais altos das colinas terciárias, mas oferece alguma possibilidade à vida agrícola" (AZEVEDO, 1945 p. 45).

Notamos com o passar do tempo as alterações administrativas e territoriais de Santo Amaro, que no momento em que se tornou Vila, contava com um território de $640 \mathrm{~km}^{2}$, tamanho esse que variou ao longo do tempo até sua anexação à Capital paulista em $1935^{19}$. A sua criação e de algumas outras vilas "deu-se numa época de grande mudança política, econômica e legislativa, circunstâncias essas que dificultavam a administração de um Município novo e pobre” (PERALTA, 2017, p. 20).

Reafirmando as condições precárias da recém-criada vila de Santo Amaro, temos registrado, segundo Peralta (2017, p. 12), que a sua origem ocorreu às margens do circuito da cana-de-açúcar e do café.

A renda do novo município advinha de poucos itens e ainda nem havia sido estabelecidas políticas para regularização das fontes de renda pelo legislativo local. "O

\footnotetext{
${ }^{19}$ Santo Amaro teve a sua primeira perda territorial em 1877, com a criação de novas vilas e a elevação de Itapecerica, anteriormente pertencente ao seu território.

Outros motivos também fizeram com que as linhas divisórias de Santo Amaro fossem alteradas, como os pedidos de sitiantes que tiveram suas terras divididas por meio das políticas oficiais das definições territoriais.

Para termos uma ideia das alterações da dimensão territorial, Santo Amaro possuía $640 \mathrm{~km}^{2}$, no inicio da sua autonomia. Hoje, como bairro de São Paulo, a Subprefeitura de Santo Amaro abrange uma área de $37,5 \mathrm{~km}^{2}$ (PERALTA, 2017, p. 16).
} 
Orçamento para o biênio 1836/1837 previa uma receita de 265\$000 e uma despesa de 474\$560, portanto um déficit ${ }^{20, " ~(P E R A L T A, ~ 2017, ~ p . ~ 46) . ~}$

A autora nos informa que ao pesquisar o balanço contábil do ano financeiro de 1878 a 1879 constatou que quase a metade da fonte do rendimento municipal advinha dos impostos "sobre tabernas e botequins e sobre aguardente e reses". No entanto, não era somente Santo Amaro que possuía uma condição financeira, econômica e de gestão desfavorável. A cidade de São Paulo era um município pobre em 1832, e ainda havia perdido parte do seu território com a criação de Santo Amaro.

A população de Santo Amaro, por volta de 1837, era de 5.131 habitantes dispersos pelo território. Muitos destes habitando fora dos limites urbanos e dificultando a arrecadação de impostos de indústrias e profissões. Entende-se aqui por indústria as atividades desenvolvidas nas pequenas fábricas ou manufaturas existentes. A grande parte dessas pequenas fábricas era composta por trabalhadores estrangeiros, migrados principalmente da Itália e Alemanha (PERALTA, 2017).

Os imigrantes que saiam da Alemanha para o Brasil, depois de uma viagem de seis meses, de Bremen para o Rio de Janeiro, eram dirigidos à Província de São Paulo, sem qualquer consulta prévia às autoridades provincianas locais, como no relato de Berardi (1981, p. 54), quando em 13 de dezembro de 1827, desembarcaram em Santos 227 colonos. Assim os imigrantes iam sendo distribuídos pelo território e enquanto não se definia a escolha de um local para a instalação dos colonos, estes recebiam um subsídio.

Outros grupos de alemães ainda chegariam ao longo de 1828, mediante decisão Imperial. Conforme iam chegando, soluções iam sendo encontradas e uma delas foi a alocação em terras devolutas de Santo Amaro. "Em 29 de junho de 1829 realizou-se a cerimônia do sorteio das terras, entre 94 famílias que desejavam estabelecer-se no lugar destinado à colônia em Santo Amaro" (BERARDI, 1981, p. 55). Deste modo ocorre a primeira instalação efetiva de uma colônia de imigrantes em São Paulo. Era um incipiente grupo de alemães que se destinava principalmente às atividades agrícolas.

Nicolau Vergueiro ${ }^{21}$ foi pioneiro, de iniciativa particular, a introduzir, em 1840, 90 colonos portugueses em sua fazenda Ibicada, nas terras do então município de Limeira.

\footnotetext{
${ }^{20}$ A unidade monetária da época era o mil-réis. Um mil réis era grafado da seguinte forma: $1 \$ 000$ (PERALTA, 2017, p. 27).
} 
A experiência teve curta duração, devido à Revolução de 1842 . Porém em 1847, a firma Vergueiro \& Cia., com o financiamento de um empréstimo do governo da Província, contratou a importação de 1.000 colonos europeus para várias fazendas.

As tentativas anteriores de colonização em São Paulo (por exemplo, a colônia alemã de Santo Amaro) tinham tido o patrocínio oficial, o mesmo acontecendo durante todo o século em outras Províncias como Rio Grande do Sul, Santa Catarina e Paraná (MORSE, 1970, p. 161).

No final do século XIX e início do XX, novos grupos de alemães, e também de escandinavos, dirigiram-se à região de Santo Amaro, com a expectativa de obtenção de terras a serem cedidas depois do advento da República ${ }^{22}$. Ao chegarem à região, muitos colonos abandonavam as terras, pois se localizavam em áreas de várzea, sujeitas às periódicas inundações ${ }^{23}$, e partiam para outras regiões do Estado ou para o sul do Brasil.

Nessa época, a economia de Santo Amaro era caracterizada pela lavoura de cereais que abastecia a cidade de São Paulo com “[...] todos os gêneros de primeira necessidade, mandioca, milho, feijão, arroz, batatas inglesas, [que] eram comprados dos santamarenses", assim como carvão, pedras e madeiras para construções, além do cultivo de trigo e algodão para os mercados da Capital e Santos (MORSE, 1970). O seu mercado público passou a ser um entreposto de atividades comerciais de produtos agrícolas, sediando encontros de tropeiros que por lá passavam e comercializavam com os produtos locais (BERARDI, 1981, p. 79).

Quanto à produção agrícola, Azevedo (1945) nos relata a pobreza do solo da região e sua produção limitada no comércio, sendo corroborado por Peralta (2017) ao afirmar que a atividade da agricultura era feita em toda região do entorno da Capital e não apenas em Santo Amaro, assim, contrapõe-se a alguns outros autores que

\footnotetext{
${ }^{21}$ Nicolau Pereira de Campos Vergueiro (1778 - 1859) - fazendeiro de café e político luso-brasileiro foi pioneiro na implementação de mão-de-obra livre no Brasil ao trazer os primeiros imigrantes europeus para trabalharem na sua fazenda no interior de São Paulo.

${ }^{22}$ É importante notar que havia vários tipos de contratos na relação dos colonos com as terras. Existiam colônias de parceria, nas quais os colonos trabalhavam para os fazendeiros recebendo salários e, às vezes, um pedaço de terra para o próprio cultivo; existiam os núcleos coloniais de caráter oficial, onde os imigrantes compravam seus próprios lotes. A fixação em terras paulistas variava muito, conforme o local e o tempo.

${ }^{23}$ Fato que facilitou a aquisição de terras, a preços baixos, e o represamento das águas para a construção da represa de Santo Amaro (Guarapiranga).
} 
afirmavam ser Santo Amaro o celeiro de São Paulo, este, porém, o grande consumidor dos produtos agrícolas produzidos em todo o seu entorno.

Apesar do solo de Santo Amaro ser considerado ruim para as grandes atividades agrícolas, ocorria produção local e, em 1837, configurava como o único município paulista que produzia batata em pequena proporção. No entanto, Santo Amaro constituía um grande polo comercial e necessitava de boas estradas para a circulação de mercadorias, sobretudo para a Capital, para onde semanalmente transitavam centenas de carros de boi (PERALTA, 2017, p. 54-55).

As atividades comerciais faziam que os vereadores, vários deles comerciantes, se deslocassem de Santo Amaro para negociar em outras vilas e cidades. Tal deslocamento era comum, principalmente para os criadores de animais, que iam, às vezes, até o Rio de Janeiro.

Peralta (2017, p. 52) ao analisar as Atas da Câmara Municipal nos atenta para os inúmeros pedidos de licença de vereadores para se ausentarem do município em virtude das atividades mercantis que acumulavam. "Em várias ocasiões, as contas da Câmara foram aprovadas em sessões com apenas 4 vereadores [Santo Amaro contava com 7 vereadores], número mínimo necessário para realização das mesmas”.

Para além do centro de São Paulo existia um grande número de núcleos suburbanos heterogêneos, parcialmente assimilados pela cidade. Eram povoações tradicionais, antigamente independentes. Santo Amaro era um destes modestos núcleos, que foi sendo assimilado, sobretudo com a construção da sua represa (MORSE, 1970).

Com isso podemos confirmar que uma das grandes atividades de Santo Amaro era o intenso comércio. Peralta (2017) encontrou em sua pesquisa diversos pedidos da Câmara de Santo Amaro ao Governador da Província solicitando reparos nas vias de comunicação, pois as estradas e pontes eram fundamentais para a circulação da produção de Santo Amaro e vizinhança.

Tanto as estradas como as pontes apresentavam problemas permanentemente e ao longo de todo o século XIX as reclamações eram constantes. Os principais motivos para a má conservação de ambas, naquele momento, era o tráfego constante dos carroceiros e também as enxurradas que acometiam as estradas, sobretudo no verão, quando ocorriam chuvas torrenciais, que "[...] arruinavam as ruas de terra e pedregulho" exigindo contínuos reparos e verbas dos cofres do município, principalmente para o conserto das ruas do centro da cidade (PERALTA, 2017, p. 68). 
A Câmara realizava sucessivos empréstimos a fim de obter recursos para as obras de conservação, como a observada para a ponte do rio Jurubatuba, região do início da ocupação territorial de Santo Amaro e que precisava ser reconstruída, pois Santo Amaro, notadamente a Vila, era um centro de passagem de tropeiros que transportavam alimentos e outros produtos para a população local e para a cidade de São Paulo.

Assim, as rotas de circulação deveriam estar muito bem conservadas e a obtenção de recursos, necessários para isso, absorvia grande parte das sessões da Câmara, conforme constatou ainda Peralta (2017) ao analisar as sessões legislativas de 1845 e 1846, a qual verificou, também, uma preocupação dos vereadores para os reparos da igreja Matriz.

Não nos esqueçamos de que os vereadores tinham interesses pessoais na conservação das vias de locomoção, pois muitos deles eram comerciantes e dependiam das estradas para o transporte de suas mercadorias.

O município de Santo Amaro, em seus primeiros vinte e cinco anos de existência teve uma arrecadação fiscal acanhada, composta basicamente da taxação das atividades do comércio com infraestrutura física aquém das suas necessidades, em condições precárias, sendo a inauguração do Cemitério em 1856, uma das primeiras e mais importantes obras. A Igreja Matriz, centro de convivência social e religiosa, ia sendo aos poucos construída e reformada constantemente, em virtude do material de baixa qualidade utilizado, tendo o seu frontispício finalizado em 1901 (PERALTA, 2017, p. 85-86).

Na segunda metade do século XIX novas atividades começaram a ser taxadas e aumentar a arrecadação municipal, como as taxas recolhidas dos enterros no Cemitério e a cobrança da nova taxa sobre os carros de boi que transitavam sobre a Ponte Grande, a partir de 1857.

As atividades agrícolas, embora prevalecessem no município, beneficiavam-no pouco na economia, sendo o comércio e as chamadas 'indústrias' os que mais favoreciam ativamente a economia:

As 'indústrias' que se desenvolveram bastante em Santo Amaro, e que 'exportavam' esses produtos para outros municípios e para São Paulo, foram as serrarias, os fornos de carvão no meio da mata, que avançaram até meados do século $\mathrm{XX}$, as pedreiras e as olarias. Estas últimas, praticamente nas 
mãos de algumas famílias italianas [...] (PERALTA, 2017, p. 124, itálico da autora).

Mas havia, também, desde o final do século XIX, “fábricas de pólvora, arreios, cerveja, vinho, louças de barro etc" e no início do século XX novas indústrias se desenvolveram, "[...] como as fábricas de macarrão, malas, carroças, fogos, sabão etc. Muitas delas tiveram vida breve" (PERALTA, 2017, p. 299).

O comércio crescia e se diversificava e quanto à mão de obra utilizada, tanto nas atividades comerciais como nas indústrias, citadas anteriormente, era composta por brasileiros e imigrantes.

Uma parcela significativa de imigrantes, sobretudo de alemães e italianos, que se dirigiam para Santo Amaro, não se dedicava à agricultura, mas exerciam atividades predominantemente urbanas, como: "sapateiros, tanoeiros ${ }^{24}$, serralheiros, torneiros, pedreiros, seleiros, carpinteiros, alfaiates, curtidores de couro, marceneiros, boticários, dentistas, cirurgiões, destiladores, tecelões, magarefes ${ }^{25}$ e outros" (PERALTA, 2017, p. 299).

Já em 1886, todos esses empreendimentos que geravam novos recursos para o município, favoreceram a instalação de uma linha de trem a vapor entre São Paulo e Santo Amaro, a Companhia de Carris de Ferro de São Paulo a Santo Amaro. Essa ligação se dava a partir da estação do Encontro, localizada, segundo Pontes (2003), na então Rua Liberdade, na porção sul de São Paulo. Ali terminava a linha de bonde que vinha da Luz (São Paulo) e começava a linha de trem da Carris que fazia o trajeto para Vila Mariana (São Paulo) e para a então cidade de Santo Amaro. Era um pequeno percurso sinuoso, mas de grande importância para a comunicação entre os dois municípios, facilitando sobremaneira o transporte de passageiros e de carga.

No início do século XX existiam duas vias que ligavam a cidade de São Paulo a Santo Amaro, eram: a linha de bondes da Light, que viera a substituir a pequena ferrovia da Carris construída entre 1883 e 1886 e a estrada de rodagem que figurava nos mapas

\footnotetext{
${ }^{24} \mathrm{O}$ que conserta ou faz tonéis, tinas, dornas, barris, pipas e outros vasilhames semelhantes (Dicionário online de português).

25 Abatedor de gado; homem que, nos matadouros, mata e esfola as reses (Dicionário online de português).
} 
da época, segundo Mendes (1958), ora com o nome de Estrada de Santo Amaro, ora com o de Estrada do Caaguaçu. Quanto à linha de bondes citada,

por se tratar de uma espécie de estrada de ferro suburbana, com paradas mais ou menos distanciadas umas das outras e tendo seu leito isolado por meio de cercas de arame, o 'Tramway' de Santo Amaro não representou um papel idêntico ao das demais linhas de bondes da cidade; ao invés de um povoamento linear, deu nascimento a uma série de núcleos, formados em torno dos pontos de parada, a exemplo do que ocorreu com o antigo 'Tramway da Cantareira' (MENDES, 1958, p. 287).

A pequena estação do Encontro é retratada pela cópia da imagem fotográfica datada de 1910 (Figura 8), na qual observamos a representação de duas composições: uma delas com carregamento de lenha que era o principal combustível para os fogões da época, obtida facilmente até meados do século XIX, provavelmente nas matas próximas ou comprada dos vendedores nas ruas, além de fornecimento de energia para máquinas a vapor, mas com o crescimento da cidade diminuía-se a oferta, seja pela procura, seja pela redução de áreas florestais (SILVA, 2008, p. 48); a outra única composição, visível ao fundo da cópia fotográfica, assemelha-se mais a um bonde, que desde 1900 era administrado pela Light e que já havia eletrificado as linhas. Veremos a imagem desta composição de maneira comparativa na cópia fotográfica seguinte (Figura 9), onde a locomotiva elétrica também é datada de 1910 e cujo registro documental da FES diz tratar-se do uso na linha de bondes de Santo Amaro. 
Figura 8 - Cópia fotográfica. Trem a vapor da Companhia Carris

de Ferro de São Paulo, na estação do Encontro, ligando São Paulo a Santo Amaro, 1910

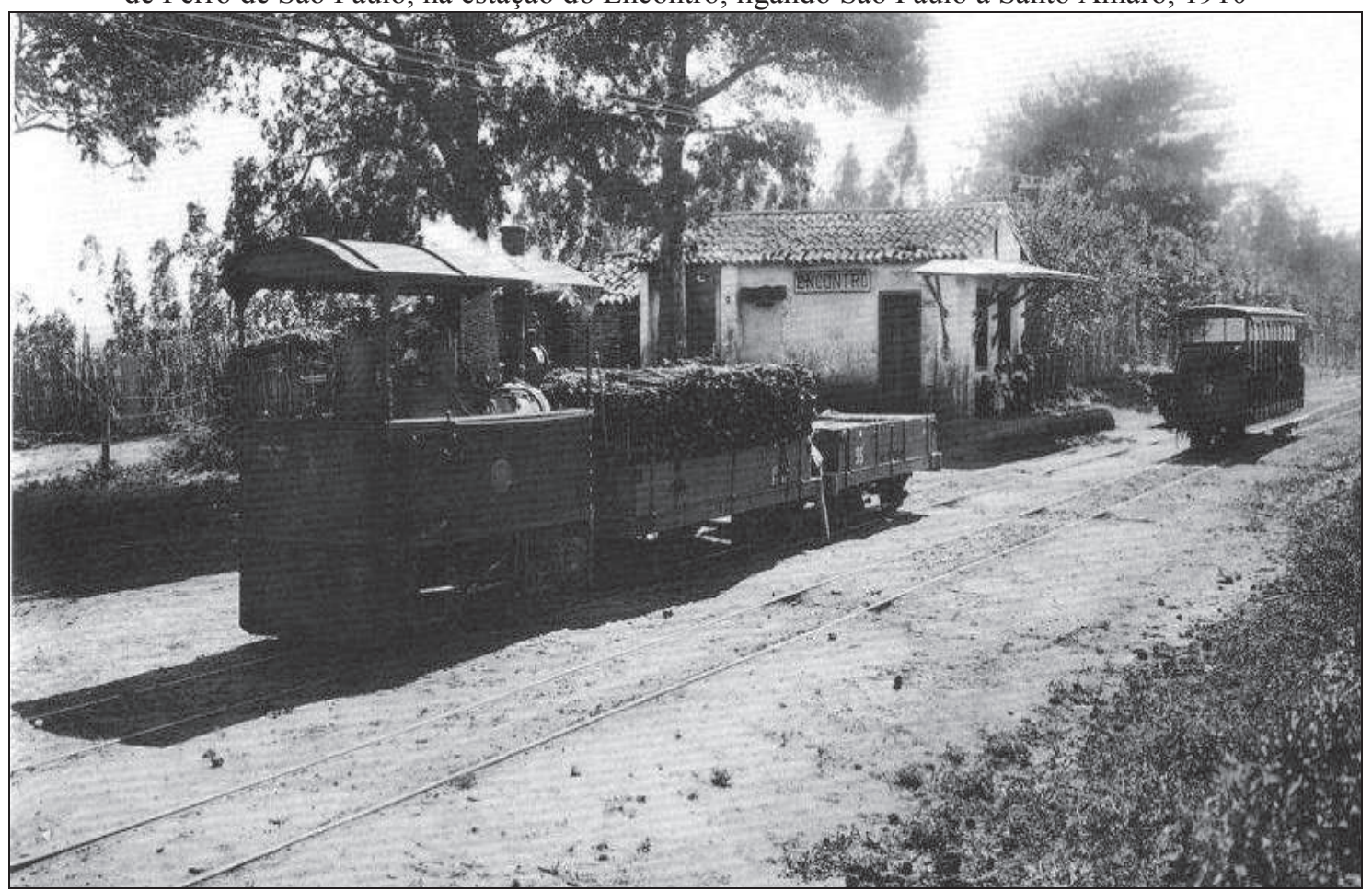

Fonte: Pontes (2003, p. 215). Crédito da foto: Aurélio BECHERINI

Figura 9 - Cópia fotográfica. Locomotiva elétrica construída na oficina da Light, carro n ${ }^{\circ} 182,1910$

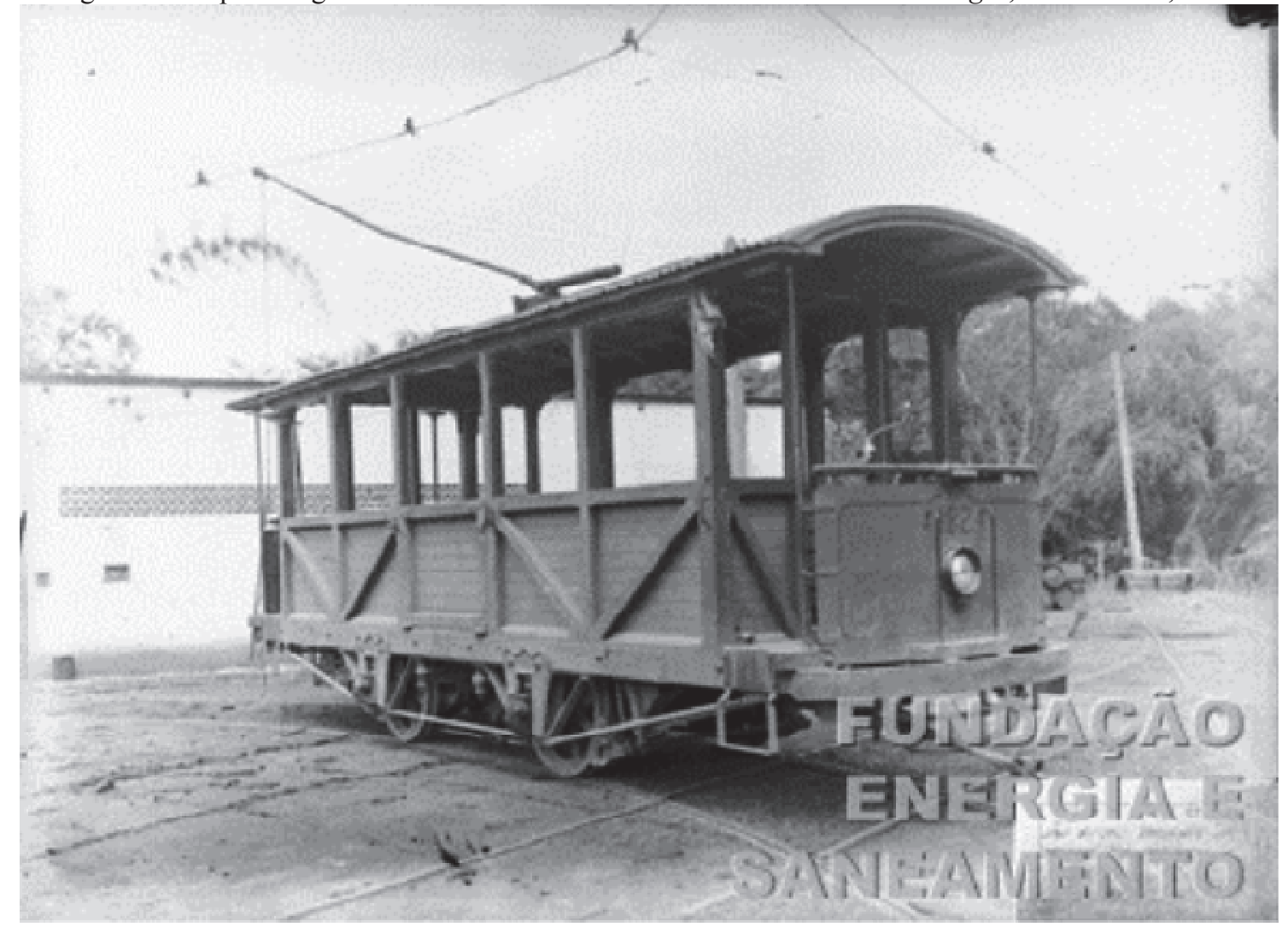

Fonte: Acervo digital da FES (2018). 16,5 x 22,5 cm [ELE.CEI.SSP.0385]

Crédito da foto: Guilherme GAENSLY 
Na legenda da Light, muito pouco visível na base direita da fotografia, somente é possível a leitura por meio do registro escrito encontrado no acervo da FES, no qual lemos em inglês: Showing Locomotive Making in our Shops. 1910/03, cujo original foi produzido em negativo de vidro pelo processo de gelatina e prata para posterior impressão em papel fotográfico monocromático para compor o álbum de imagens fotográficas da Light. Notamos grande semelhança nas composições imagéticas e o que elas representavam, embora o fotógrafo, a posição e a distância do objeto fotografado não sejam exatamente os mesmos.

Complementando, temos na cópia fotográfica de 1916 (Figura 10), a representação da estação ferroviária de Santo Amaro, destacando as linhas eletrificadas sustentadas por postes e os bondes na estação da entrada da cidade, que servia para embarque e desembarque de cargas e pessoas. Existia também outra estação no centro de Santo Amaro, na proximidade da Igreja Matriz e era utilizada apenas para o transporte de passageiros (PERALTA, 2017).

Figura 10 - Estação de Santo Amaro para cargas e passageiros na entrada da Vila, 1916

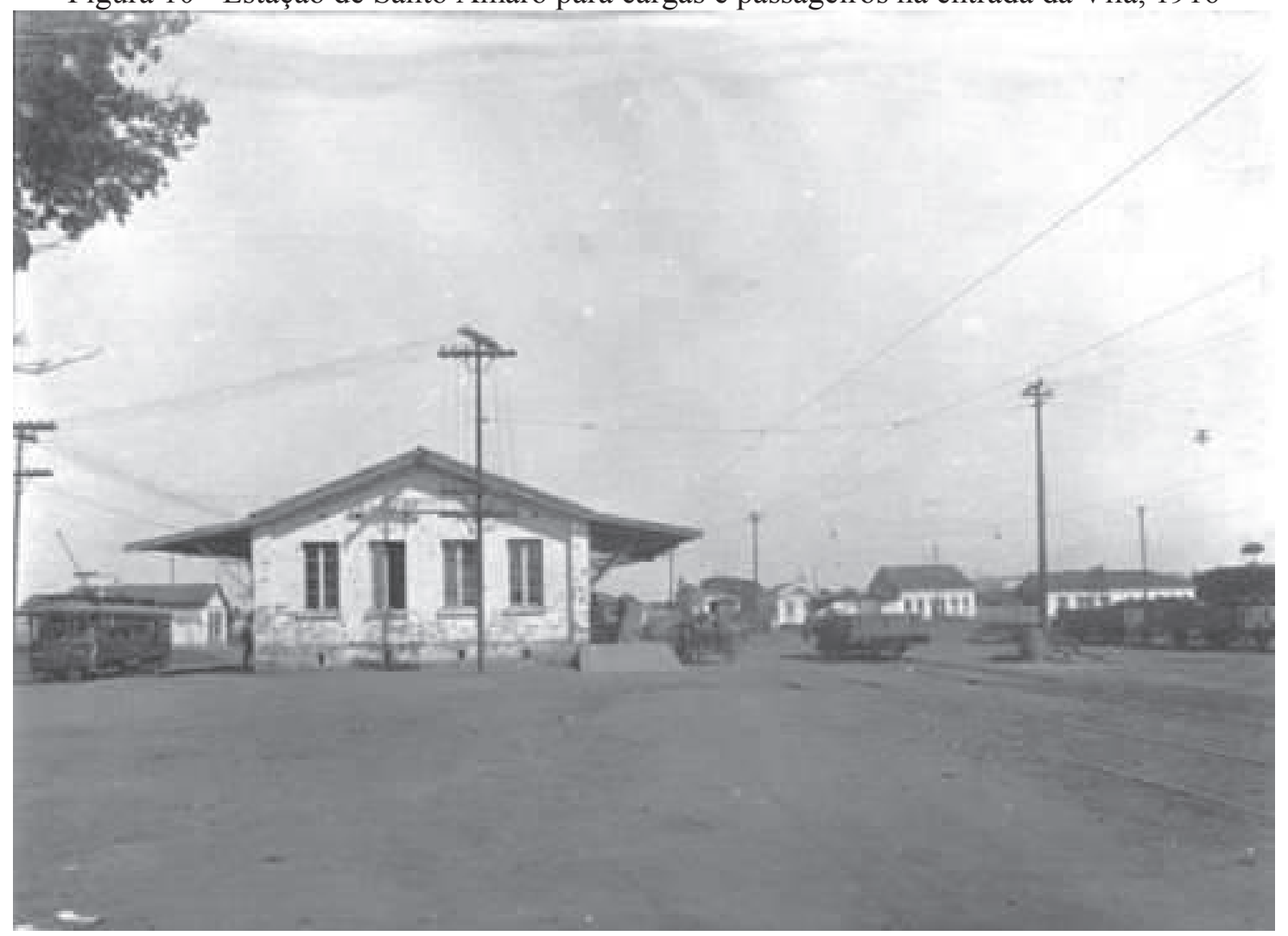

Fonte: Peralta (2017, p. 162). 
Tal desenvolvimento fez surgir à margem da linha de bondes da Light os primeiros loteamentos da porção sul da Capital, pertencentes à vertente esquerda do rio Pinheiros. Posteriormente, a construção da represa Guarapiranga também foi um fator que gerou desenvolvimento e ocupação na região São Paulo-Santo Amaro (MENDES, 1958, p. 288).

Quanto à Carris de Ferro, esta foi idealizada pelo engenheiro Georg Kuhlmann ${ }^{26}$, para o transporte inicialmente de carga. À época da inauguração, 14 de novembro de 1886, por se tratar de um feito que alterou as relações de transporte e comunicação, contou com a presença do imperador D. Pedro II (1825-1891), muito favorável, como sabemos, às inovações tecnológicas que marcavam a sua época.

A visita do casal imperial promoveu mudanças em Santo Amaro e gerou grandes despesas para a Câmara local, mas passada a euforia da visita, a Câmara "voltou a sua indolência tradicional funcionando, a maior parte das sessões do ano de 1886, com apenas 04 vereadores" (PERALTA, 2017, p. 151) ${ }^{27}$.

Entre São Paulo e Santo Amaro a viagem de trem tinha duração de cerca de uma hora e meia e "[...] foram construídas as estações: São Joaquim, inicial; Vila Mariana; Estação do Encontro; Volta Redonda; Santo Amaro, [...] e Ponto da Vila" (PERALTA, 2017, p. 161 e 164).

Em 1900 a Companhia Carris de Ferro, acumulando inúmeras reclamações dos usuários e com muitas dívidas, entrou em liquidação, tendo a sua massa falida adquirida pela The São Paulo Railway Light and Power Company por uma valor de 15:000\$000, em torno de trinta e sete vezes abaixo do valor avaliado e explorou a linha até 1913, o

${ }^{26}$ Georg Albrecht Hermann Kuhlmann (Alemanha, 1845 -1905): Engenheiro formado pela Escola Politécnica do Rio de Janeiro. Naturalizou-se brasileiro e desenvolveu diversos projetos técnicos durante o século XIX para a cidade e o Estado de São Paulo. À época da instalação das linhas de bondes, Kuhlmann era o gerente da Companhia Carris de Ferro (BERARDI, 1981).

27 Para a visita do Imperador "inauguraram-se vinte e dois lampiões a querosene [...] a Câmara sofreu uma reforma geral, as ruas foram enfeitadas [...] Foi um dia de festa para a vila: todos foram ver o Imperador, que desceu na estação do trenzinho e dirigiu-se com a comitiva para a Igreja Matriz. Foram todos depois à Câmara Municipal, onde se lavrou uma ata especial (BERARDI, 1981, p. 87-88).

A viagem de trem de São Paulo até Santo Amaro contou com enfeites e rica mobília com as armas imperiais e "percorreram os 18 quilômetros da via férrea enfeitada com arcos de folhagem. As estações também estavam adornadas", com muitas pessoas ao longo da ferrovia para ver a comitiva e o casal imperial passar. D. Pedro II visitou a igreja, a Câmara e a cadeia em uma visita de aproximadamente três horas. Após a visita, o trem levou a comitiva de volta para a estação em Vila Mariana e em seguida dirigiram-se para a região Central. Notamos que, à época, Vila Mariana era um arrabalde da Capital (PERALTA, 2017, p. 150-151). 
que lhe facilitou o transporte de materiais destinados à construção da represa Guarapiranga e possibilitou a inserção de novas áreas aos seus domínios.

A Light assim assumiu as locomotivas com seus vagões destinados ao transporte de lenha e água necessárias para a alimentação da máquina; catorze carros para passageiros; oito carros para o transporte de carnes do matadouro municipal; catorze carros de transporte de mercadorias e diversos outros carros que se encontravam em reparo nas oficinas (PERALTA, 2017, p. 164).

O fato que nos chamou a atenção foi a Light ter reduzido o trecho de São Paulo a Santo Amaro, passando a contar com cerca de $16 \mathrm{~km}$, dois quilômetros a menos, além de eletrificar a linha, possibilitando com essa redução do percurso maior lucratividade para a companhia.

Enquanto isso, a administração municipal de Santo Amaro enfrentava o problema da iluminação pública. Desde 1885, as ruas principais da cidade eram iluminadas por lampiões a querosene, fato que gerava muito descontentamento e reclamações por parte da população, devido a pouca luminosidade e ao serviço precário.

Empréstimos foram feitos para atender a essa e outras demandas e em 1907 a iluminação das ruas do centro de Santo Amaro passou a ser a gás acetileno, com os seus novos 24 lampiões colocados nos postes dos antigos lampiões a querosene. Posteriormente, a Prefeitura abriu concorrência para a iluminação pública e particular por meio de eletricidade. A Light interferia diretamente na gestão pública a fim de ter atendidas as suas iniciativas, como o fato da implantação dos serviços de luz e viação por eletricidade em Santo Amaro, a qual conseguiu aprovação em primeira sessão da Câmara em 1911 (PERALTA, 2017, p. 275).

Santo Amaro tornou-se município (1832) em uma conjuntura provisória, a Regência, e perdeu sua autonomia (1935) em uma conjuntura de exceção, a tomada do poder por Getúlio Vargas. Vale notar que Santo Amaro não foi o único município a perder a autonomia nessa época, outros tiveram o mesmo destino. Um pouco antes da anexação de Santo Amaro, quando Getúlio Vargas toma o poder, ele altera as instâncias administrativas, nomeia interventores nos Estados e, pelo Decreto Federal n ${ }^{\circ} 19.389$, de 11 de setembro de 1930, o então “[...] Governo Provisório da República dos Estados 
Unidos do Brasil ${ }^{28}$ extinguiu todos os órgãos legislativos ou deliberativos do País. As câmaras municipais, portanto, foram extintas" (PERALTA, 2017, p. 435 e 451).

A questão, no entanto, é controversa. Na leitura de Jorge (2015, p. 228), a anexação de Santo Amaro a São Paulo se dá em virtude do desenvolvimento urbanístico e turístico do entorno da já criada represa Guarapiranga e sua função central no abastecimento de água, preocupação essa, em período a posteriori a sua formação e juntamente com a construção de outros complexos hidrelétricos na região, Santo Amaro tornou-se um território extremamente valorizado, social, político e economicamente.

Para Peralta (2017), no entanto, a justificativa para a perda de autonomia de Santo Amaro estava na difícil situação econômica e financeira do então município, tendo o interventor no Estado apenas legalizado uma situação concreta: Santo Amaro dependia economicamente de São Paulo para se desenvolver. A vila e cidade de Santo Amaro praticamente sempre pertenceram à comarca de São Paulo, constituindo uma área de influência da Capital para as suas atividades.

Além disso, outra razão que justificou a anexação territorial de Santo Amaro está no fato de que várias vilas passaram a sediar suas comarcas ainda no século XIX, constituindo “[...] outro dado que minimizou a importância econômica e política de Santo Amaro [...] não ter sido elevada à categoria de cidade no século XIX, enquanto as outras vilas, criadas em 1832, o foram" (PERALTA, 2017, p. 19). Além das dívidas que o município tinha com a Secretaria de Viação e Obras Públicas do Estado, servindo, também, como justificativa para a sua anexação à Capital, fato que cancelou seus débitos com a Secretaria de Estado da Fazenda.

No entanto, em um relato de Berardi (1981, p. 107) há referência de que neste período Santo Amaro estava expandindo a sua indústria, comércio e a sua zona residencial, progressos estes que iam em direção oposta a uma definição de região decadente que se pretendia apresentar.

Não podemos deixar de registrar que as diversas melhorias feitas para a comunicação entre Santo Amaro e São Paulo permitiram, ao longo das estradas criadas e reformadas, o surgimento de loteamentos de inúmeros terrenos, que levavam em

${ }^{28}$ Em 1969, por meio de uma emenda que alterou o texto da Constituição de 1967, a denominação oficial do país passou a ser República Federativa do Brasil, nome que permanece até hoje. 
consideração apenas os interesses dos incorporadores capitalistas. Tal fato, associado ao parcelamento das grandes áreas, elevou os impostos, onerando demasiadamente os proprietários e beneficiando os cofres públicos.

O parcelamento do solo em extensas áreas levou a uma proliferação de loteamentos que se transformaram em bairros compostos basicamente por residências “[...] habitadas por operários ou modestos funcionários públicos, cujas atividades são exercidas na capital”, Penteado (1958, apud PERALTA, 2017, p. 360). Tal ocupação espacial ocasionou um prolongamento expansionista por meio de loteamentos residenciais em direção à Capital e praticamente sem vínculo funcional com a cidade de Santo Amaro, intensificado em primórdios do século XX. Na região estava ocorrendo o desenvolvimento urbano policêntrico, no qual espaços urbanos se desenvolvem e crescem ao encontro um do outro, para após se conurbarem. Tal evento ocorreu, mas Santo Amaro já havia sido anexado administrativamente à Capital em 1935.

\section{5 - A constituição da Light e sua atuação na Guarapiranga}

No final do século XIX, São Paulo já se configurava em um vasto mercado em expansão e os investidores privados, mesmo de longe, estavam sempre atentos aos movimentos que proporcionariam lucratividades para os seus empreendimentos.

A constituição da Light está diretamente ligada à formação de monopólios e ao grande investimento de capitais internacionais, "sendo decorrente do progresso técnico e das transformações econômicas vinculadas à revolução científico-tecnológica, principalmente no que diz respeito ao controle e aproveitamento das novas fontes de energia" (SILVA, 2008, p. 36).

Os idealizadores vislumbravam a certeza dos potenciais da nova empreitada e resolveram levar adiante o projeto de constituir uma empresa de força e luz em terras brasileiras, logicamente em um local de ascensão econômica, além de aproveitarem, conforme Hobsbawm (1998), o excedente de capital acumulado em fins do século XIX.

A construção do represamento das águas do rio Guarapiranga, motivada para a produção de energia elétrica, no então município de Santo Amaro, não ocorreu por estímulos locais e sim em virtude dos interesses vinculados ao desenvolvimento 
econômico da Capital paulista em uma rede global de negociações e, segundo Jorge (2015, p. 212),

[...] em um momento de intensificação dos fluxos de pessoas, capitais, mercadorias e ideias entre diferentes partes do planeta em decorrência de expansão da economia capitalista. O que implicou na assimilação das inovações tecnológicas e científicas que se originaram, especialmente, nos países do norte da Europa Ocidental e EUA, no contexto da chamada $2^{\mathrm{a}}$ Revolução Industrial. Dentre essas inovações, a eletricidade.

A atenção despendida por parte dos empreendedores estrangeiros com vistas à atuação no território paulista contou com a articulação do advogado e empresário William Mackenzie, executivo-chefe da Toronto Street Railway Company, do engenheiro elétrico Fred Stark Pearson, que fazia parte de um grande escritório de engenharia em Nova Iorque e tinha grande experiência em companhias de força e luz para analisar o relatório do também engenheiro Robert Calthrop Brown que, algumas semanas antes, havia estado na cidade de São Paulo com o objetivo de avaliar a possibilidade de se fundar uma companhia similar à Toronto Street Railway (SÁVIO, 2015, p. 121).

Em São Paulo havia ainda a participação de políticos como "o governador Bernardino de Campos e de sua família nos negócios da Light, além de outras figuras importantes da sociedade que integravam essa empreitada". Havia também a presença de uma equipe técnica para a constituição do grupo Light, que ultrapassava as experiências anteriores no montante de capital investido e na organização técnica, mas a sua ação seguiu o padrão de organização que tinha como objetivos a ampliação das concessões e a monopolização gradual dos serviços urbanos, para a maximização dos lucros e influências nas áreas de atuação (SILVA, 2008, p. 37).

Assim, em 7 de abril de 1899, na cidade de Toronto, no Canadá, por meio de carta patente de incorporação, concedida pela Rainha Vitória do Reino Unido, foi fundada a The São Paulo Railway Light \& Power Co. Ltd., a Light, com o intuito de explorar os serviços de viação por eletricidade no transporte de passageiros e de cargas na cidade de São Paulo. Destarte, o primeiro estatuto da nova companhia foi assinado e compôs-se a sua Diretoria, que embora tivesse a sua formação jurídica ocorrida distante do Brasil, representava o reflexo dos desdobramentos do capital desterritorializado, mas de presença marcante na atuação por onde adentrava. 
Mais tarde, por já existir a San Paulo Railway Co., procurou-se trocar o "Railway" por "Tramway". Segue daí a nova denominação, The São Paulo Tramway, Light \& Power Co., Ltd., que acompanhou a empresa até a sua incorporação pelo Estado décadas mais tarde ${ }^{29}$ (SOUZA, 1982, p. 40), Vale ressaltar que com a República e o federalismo, o Estado de São Paulo tinha mais autonomia e recursos do que na época do Império escravista, conforme Jorge (2012).

A Light foi autorizada a funcionar mediante Decreto e fora fundada com capital inicial de seis milhões de dólares, equivalente, ao câmbio do ano, a cerca de quarenta mil contos de réis (SAES, 1986).

As circunstâncias em que a Light se estabeleceu no Brasil não teriam significado impeditivos para que o capital nacional também o fizesse. Conforme análise de Saes (1986, p. 153-154), os quarenta mil contos de réis não superavam "o capital realizado da Companhia Paulista de Estradas de Ferro em 1899 - cerca de 60.000 contos - embora este fosse também o resultado de quase trinta anos de expansão" e as condições técnicas para a produção de energia em hidrelétrica já existiam, embora em proporção muito menor que a grande usina da Light projetada para Parnaíba, porém, naquele momento o mesmo modo que "a técnica importada permitiu o desenvolvimento de empresas nacionais de estradas de ferro, não nos parece que a técnica de barragens para produção de energia pudesse constituir obstáculo ao desenvolvimento desse setor sob o domínio nacional".

Em julho de 1899, uma petição da Light para o Presidente da República, Campos Salles (1841 - 1913), solicitava autorização para a empresa funcionar no Brasil, além de relatar que a empresa já havia adquirido terras no município de Parnaíba, que incluía uma queda d'água no rio Tietê, a qual pretendia utilizar para abastecer São Paulo de eletricidade. Assim, pelo Decreto $n^{\circ} 3.349$, de 17 de julho de 1899, foi concedida a autorização mediante cláusulas assinadas pelo Ministro da Indústria, Viação e Obras Públicas e a exigência da "manutenção de um representante com plenos poderes no País, e obrigação de se submeter às leis nacionais nos atos praticados no Brasil e ficando ainda qualquer alteração dos estatutos dependente de autorização do Governo Federal" (SOUZA,1982, p. 28).

\footnotetext{
${ }^{29}$ O processo de nacionalização do setor de energia elétrica no Brasil foi iniciado em 1961 com a aprovação da lei que criou a Eletrobrás. Em 1981, o Governo do Estado de São Paulo adquiriu a parte paulista da Light e criou a sua própria empresa de energia, com o nome de Eletropaulo (FUNDAÇÃO ENERGIA E SANEAMENTO, 2017).
} 
Legalmente instalada no País, iniciam-se as obras que aos poucos alterariam a paisagem de parte de São Paulo, por meio da implementação de técnicas construtivas que pretendiam fazer expandir suas relações econômicas. Tal fato fez com que diretores da companhia recém-criada se aproximassem ainda mais de notáveis engenheiros, com experiências em obras desse porte, como o americano Frederick Stark Pearson ${ }^{30}$, então Engenheiro-Chefe da Metropolitan Street Railway, de Nova Iorque, que já tinha realizado diversas obras importantes nos Estados Unidos. Assim, quando a Light definitivamente se estabelece no Brasil, via São Paulo, em 1900, foi acionada a primeira usina termelétrica a vapor constituída por dois geradores na região central da cidade (rua São Caetano) e a primeira linha de bonde, também no centro (da alameda Barão de Limeira ao largo de São Bento). "O passo seguinte da empresa foi tentar estabelecer o monopólio dos serviços avançando sobre as demais empresas, como a Companhia de Água e Luz de São Paulo e a Companhia de Viação Pública, e, mais tarde, a disputa com a San Paulo Gas Company" (SILVA, 2008, p. 37-38). A empresa, segundo Souza (1982), ficaria conhecida como o polvo canadense, designação dada à companhia em uma alusão aos tentáculos do molusco e a sua voracidade de absorver todas as atividades lucrativas da urbe.

No início das atividades da Light, muitas indústrias tinham a sua própria fonte de energia, com geradores próprios, em sua maioria acionados a vapor. As máquinas dependiam de instalações elétricas que foram inicialmente organizadas por grupos ligados ao café e com o passar do tempo a expansão industrial passou a exigir novos equipamentos e redes mais amplas de eletricidade, a fim de possibilitar maior produtividade, somente exequível por meio de grandes investimentos e inovação tecnológica, ambos proporcionados pela Light.

A companhia já havia utilizado os estudos topográficos realizados há duas décadas antes da sua chegada no Brasil, feitos pela equipe de Orville Derby ${ }^{31}$, da Comissão Geográfica e Geológica do Estado de São Paulo - CGG de SP (Sávio 2015) e ainda analisou mais detalhadamente as diversas fontes de força hidráulica aproveitáveis.

\footnotetext{
30 Frederick Stark Pearson (EUA, 1861 - Oceano Atlântico, 1915): Engenheiro elétrico. Participou do desenvolvimento do sistema de transporte elétrico de cidades americanas como Boston e Nova Iorque e esteve à frente em diversos projetos de construção de hidroelétricas na América do Norte e do Sul (DICTIONARY CANADIAN BIOGRAPHY, 2018).

${ }^{31}$ Orville Adalbert Derby (EUA, 1851 - Brasil, 1915): Geólogo americano, naturalizado brasileiro e considerado o pai da Geologia no Brasil.
} 
"Este estudo revelou a existência de uma cachoeira possuindo os necessários elementos de valor geral, situada no rio Tietê, na Vila de Parnaíba, a distância de 33 quilômetros da cidade de São Paulo [...]" (SOUZA, 1982, p. 55).

A respeito da queda d'água, onde o rio Tietê tornava-se estreito e encachoeirado, possuía uma área coberta de densa vegetação e "tinha o rio uma queda de 12 metros, formando o que no lugar se denominava Cachoeira do Inferno" (SOUZA, 1982, p. 55, itálico do autor).

Os estudos ainda apontavam a existência de uma estação ferroviária próxima, a estação de Barueri, uma das primeiras estações da Estrada de Ferro Sorocabana, inaugurada em 1875. Tal fato facilitaria, sobremaneira, o transporte de materiais e homens para a construção da hidroelétrica em Parnaíba, cujas obras foram marcadas por diversos conflitos de interesses entre a Light, o poder público e a população dos locais das obras, todos eles pelo controle do espaço ou do que poderiam beneficiar-se dele. Somam-se a essas dificuldades, os desafios técnicos da portentosa obra de engenharia.

A construção da principal e maior hidrelétrica do país, na época, transformou a paisagem local e segundo Sávio (2015, p. 129-131) promoveu a "transformação da paisagem 'natural' em uma paisagem 'humana' [e] foi amplamente explorada pela empresa canadense" a fim de "debelar os eventuais desgastes que ela poderia enfrentar nos anos seguintes em virtude de disputas envolvendo seus interesses”. Assim, utilizouse principalmente "da sedução que a tecnologia poderia fornecer às elites urbanas paulistanas, [...] fez do canteiro de obras uma peça de propaganda [...]. A construção da usina se transformou num grande espetáculo".

Com a crescente visitação e o interesse cada vez maior em conhecer as obras da usina em Parnaíba, a Light contratou um serviço de fotografia a fim de documentar e propagandear a transformação da Cachoeira do Inferno. Com essa produção iconográfica, a companhia pretendia também desfocar

as ocorrências de acidentes no canteiro de obras que, não raro, vitimavam trabalhadores em resultado, em boa parte das vezes, do uso de dinamite em explosões mal calculadas, mas que podiam ser vistos em acidentes com as gigantescas pedras trazidas em carros de boi [...] (SÁVIO, 2015, p. 131).

As construções para o represamento das águas e instalação das turbinas foram iniciadas em Parnaíba a 6 de junho de 1900 e inauguradas em 23 de setembro de 1901 
pelo então Presidente do Estado de São Paulo, Conselheiro Rodrigues Alves (1848 1919), que inaugurou a represa sobre o rio Tietê e pelo Prefeito de São Paulo, Conselheiro Antônio Prado, que inaugurou o reservatório de acumulação de águas para acionar as turbinas, este também participara das solenidades de início das obras. Ambos receberam uma colher de prata da Light pela solenidade comemorativa das inaugurações (SOUZA, 1982).

Apesar da existência de pequenas geradoras de energia, a Usina de Parnaíba foi a primeira hidrelétrica de grande porte em São Paulo e movimentou o meio político que comparecia para visitá-la. O escritor modernista, Oswald de Andrade (1890 - 1954), cujo pai era vereador em São Paulo, relembra as descrições da excursão:

Meu pai contava que atravessara, sem se curvar, por dentro de canos enormes por onde passaria a água represada. Um mistério esse negócio de eletricidade. Ninguém sabia como era. Como é que funcionava. Para isso as ruas da pequena São Paulo enchiam-se de fios e postes (Andrade apud SILVA, 2008, p. 47).

Observamos na crônica do escritor, que o grandioso empreendimento da Light marcaria definitivamente a paisagem, seja com as usinas e represamentos de água em locais afastados, seja na cidade de São Paulo por meio dos fios e postes que tanto impressionaram o pai do escritor.

Quanto aos canos usados em Parnaíba e sua grandiosidade, podemos melhor analisá-los por meio da cópia fotográfica da época (Figura 11), na qual observamos a sua dimensão e temos uma projeção de escala a partir do comparativo dos grupos humanos que estão na imagem, sobretudo no centro da foto, na qual o fotógrafo (não referenciado) focalizou o cano e um homem abaixo dele, sugerindo a envergadura da obra, inclusive com a presença de uma escada escorada no cano, dando-nos a ideia da altura.

Notamos que na porção central à esquerda da foto, em cima de um andaime, estão perfilados alguns homens, provavelmente trabalhadores e à frente da fileira humana está a figura de um homem de trajes claros, destacada neste jogo de luz e sombras das fotos em preto e branco, possivelmente um engenheiro ou supervisor, com os demais homens atrás da sua presença como a imitá-lo em sua pose e a dimensionar a ação humana sobre a obra. Observamos, também, a presença de um carro com bovino, 
no centro da foto, à direita, posicionado atrás do cano, sendo muito utilizado para o transporte de cargas conforme a época pesquisada.

Figura 11 - Cópia fotográfica. Obras do conduto forçado, entre os reservatórios na unidade de Parnaíba, em trecho sobre antigo leito do rio Tietê (Santana de Parnaíba), 22.08.1900

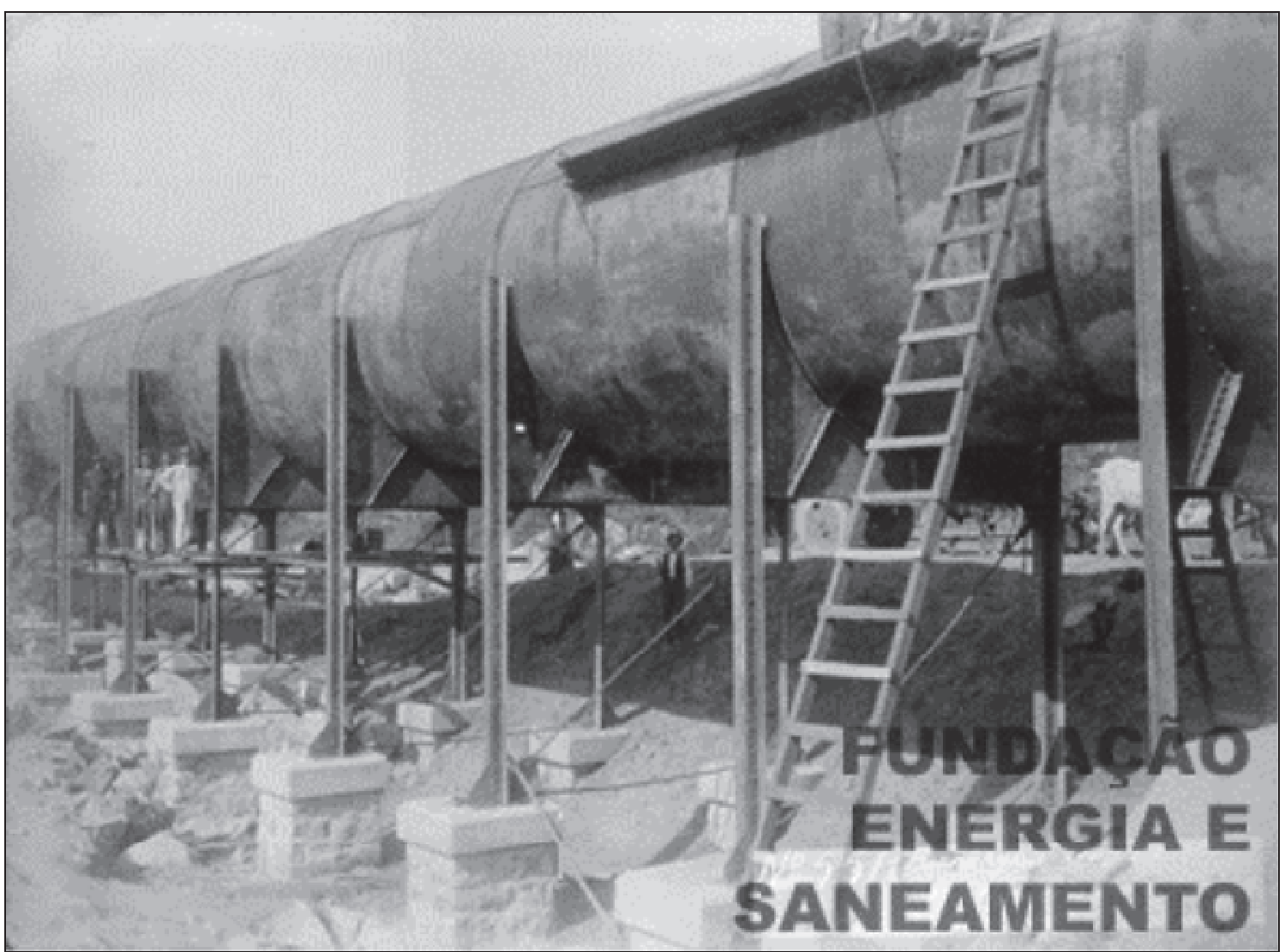

Fonte: Acervo digital da FES (2018). 17,5 x 23,5 cm [ELE.CEI.PAR.0551]

Muito das imagens produzidas da construção em Parnaíba eram, a nosso ver, parecidas com a construção da Guarapiranga, na qual a intervenção técnica da Light no território acabava por alterar a fisionomia da paisagem. Poucas referências são encontradas sobre o período da construção da Guarapiranga, com exceção dos estudos de Jorge (2015).

Embora haja pouco material redigido sobre a construção da Guarapiranga, temos nas fotografias registradas uma representação de fatos, constituindo um suporte documental que nos permite discorrer sobre a história, sobre o processo de transformação da paisagem e sobre as técnicas utilizadas. 
A fonte imagética auxilia-nos na leitura da atuação da empresa no espaço físico. Ela registra a presença de grandes canos a serem usados na obra e os suportes de apoio, como próteses a inserir no território a técnica de uma nova constituição espacial (SANTOS, 2013).

Notamos grande semelhança nos registros imagéticos da Light ao retratar os suportes técnicos nas duas obras distintas, mas ao mesmo tempo similares em seus objetivos e conteúdos, tanto que na construção ocorrida em Parnaíba, o prefeito do município de São Paulo estava presente e em destaque na inauguração da obra. $\mathrm{O}$ fato reside na importância política da figura do Conselheiro e de São Paulo no cenário regional/nacional, além das construções servirem para favorecer, mais precisamente, o desenvolvimento econômico da Capital e a sua classe social hegemônica, agregando mais valor ao território paulistano.

A seguir, registramos a importância do evento da construção da usina hidrelétrica em Parnaíba por meio de um banquete realizado na casa de máquinas da usina, onde se reuniram

[...] a fina flor da política e da economia - o PRP [Partido Republicano Paulista] em peso, a Light em peso, os dirigentes das estradas de ferro - e eminências da inteligência paulista como o arquiteto Ramos de Azevedo, o diretor da Escola Politécnica, engenheiro Paula Sousa, o diretor do Mackenzie College (estabelecido na cidade havia já 31 anos), Horácio Lane, e o diretor da Comissão Geográfica e Geológica (organizada pelo governo estadual para explorar e estudar os vastos sertões então desconhecidos do oeste do estado), o geólogo Orville Derby (TOLEDO, 2015, p. 47).

Pretendia-se com a obra recém-inaugurada “[...] o fornecimento de energia para movimentar os bondes elétricos, e com o excedente, a iluminação pública e a venda ao comércio, à indústria e às residências" (TOLEDO, 2015, p. 43). O uso da eletricidade avançou ao longo das primeiras décadas do século XX, sobretudo nas fábricas, em substituição a outras formas de energia, como o gás, obtido desde 1872 pela queima do carvão, na Casa das Retortas "[...] um dos trabalhos mais insalubres que a cidade [de São Paulo] conheceu em todos os tempos" (JORGE, 2015, p. 214).

Em 1891, parte da cidade já contava com iluminação elétrica, fornecida por uma máquina a vapor de 50 kilowatts da Companhia Água e Luz de São Paulo. No entanto, em 1900, a Light absorveu essa companhia e complementou a energia com a usina de 
força de Parnaíba, no rio Tietê, mas logo se viu que as águas desse rio, na sua descida lenta para o interior, não seriam suficientes para as necessidades cada vez maiores que a cidade iria ter de energia. Assim, a Light motivou-se a construir um sistema de barragens para represar os vales alagadiços de diversos tributários originais do Tietê, nas proximidades das cristas chuvosas da Serra do Mar, nos vales do rio Guarapiranga (MORSE, 1970).

A Light rapidamente deixou em segundo plano os investimentos em bondes e passou a priorizar a venda de energia elétrica, pois era uma atividade muito mais lucrativa, voltando as suas atenções para a Cachoeira do Inferno e como fazer para potencializá-la (SÁVIO, 2015).

Com a instalação das turbinas em Parnaíba e a consequente necessidade de consumo de água para fazê-las funcionarem, a Light não poderia deixar de regularizar a vazão do rio Tietê, pois eram as águas deste rio que serviam de fonte energética para movimentar as turbinas. Assim, uma represa para normalizar o armazenamento de água deveria ser construída, embora uma pequena represa fora instalada em Parnaíba. Ela, porém, era insuficiente. Além do mais, o Estado de São Paulo é marcado por um regime pluviométrico que oscila entre o verão chuvoso e o inverno seco, alterando a vazão dos rios e córregos da bacia do Alto Tietê, fato que diminuiria a capacidade de produção energética de Parnaíba, caso não houvesse um sistema de armazenamento considerável de água.

Não era possível criar um grande reservatório em Parnaíba, sem afetar o regime de águas do rio Tietê e consequentemente a cidade de São Paulo, que fica a montante, conforme relatado por Souza (1982).

Estudos apontaram uma opção viável, tanto pela perspectiva técnica como financeira, se utilizassem as águas do rio Guarapiranga em Santo Amaro, afluente do rio Pinheiros, que é tributário do rio Tietê, dentro da bacia hidrográfica do Alto Tietê. Assim, na época das chuvas, a água poderia ser acumulada na represa Guarapiranga e nos meses de seca ser vertida no rio Pinheiros, chegando por meio deste ao rio Tietê e à usina hidrelétrica de Parnaíba.

A planície onde se localizaria o lago artificial da Guarapiranga foi também analisada em seus aspectos físicos, por meio de pesquisas, como a composição do solo, a geomorfologia e a hidrografia. A ideia ia ao encontro da visão economicista de exploração territorial associada ao discurso da ciência moderna (FIGUEIRÔA, 2008). 
Em nenhum momento, conforme pesquisado, houve a preocupação com a população residente local. O foco estava unicamente na construção e nos benefícios que ela traria para os grupos hegemônicos do poder político e econômico. A população é citada nos casos de indenizações e nos empecilhos que criavam nesse sentido e na sua utilização como mão de obra operacional.

A construção para o represamento das águas do rio Guarapiranga era uma ação necessária para garantir a maximização do potencial hidrelétrico da usina de Parnaíba e suas obras tiveram início em 1906, pela Light $^{32}$. Não devemos esquecer que a companhia canadense, ao instalar-se na cidade de São Paulo, tinha como objetivo primeiro explorar os serviços de produção e distribuição de energia elétrica para os serviços de transporte e iluminação pública, na cidade que se urbanizava rapidamente e o uso da eletricidade como vetor energético estava se desenvolvendo e se fixando na área dominada pelo carvão e à máquina a vapor.

A lenha era muito utilizada e as grandes árvores preservadas eram aquelas que não serviam para o fornecimento da queima ou que não constituíam um empecilho ao avanço dos empreendimentos do capital, tornando-se vestígios da preservação, não consciente, mas sim pelo princípio da racionalização econômica e em uma região com predomínio de arbustos e vegetação de pequeno porte ${ }^{33}$.

A construção da represa estava inserida no contexto global de produção de energia elétrica e iria alterar completamente a paisagem da região, transformando-a, em parte, em um imenso lago.

O ano que se inicia a construção da Guarapiranga, 1906, registra outras formas de acelerada penetração do capital estrangeiro. Tal penetração se faz notar em setores e empresas antes dominadas pelo capital paulista ou se aprofunda naqueles já ligados fortemente a empresas estrangeiras.

Em São Paulo, o principal setor afetado pelo avanço do capital estrangeiro foi o de estradas de ferro; no de energia, a tendência se manteve: a Light expande suas

\footnotetext{
${ }^{32}$ As obras foram iniciadas após a Light conseguir a concessão para o represamento das águas, sob a supervisão do engenheiro estadunidense Mark Maurice Murtaugh, que havia trabalhado no Estado de Idaho, EUA, na represa do principal rio da região do Pacífico Noroeste, o Snake River. A conclusão da Guarapiranga foi em 1909, estando à frente da obra o engenheiro, também estadunidense, Thomas Berry (SOUZA, 1982).

${ }^{33}$ Muitas árvores centenárias existentes hoje na cidade são resquícios desse processo, como aquelas que ainda existem no Jardim da Luz em São Paulo, Jardim este que foi cerne ao projeto de criação, em 1928, do Jardim Botânico (PATACA, 2015).
} 
atividades enquanto se multiplicam as empresas nacionais no interior, por vezes dominadas por grupos locais. O setor bancário também expandirá o capital estrangeiro com abertura de novas agências. Essas tendências serão afetadas pelo conflito bélico mundial em 1914, impondo restrições ao fluxo de capital internacional (SAES, 1986, p. 167).

No setor de energia elétrica,

o período de 1906 a 1918 acentuou as tendências antes anotadas: por um lado, o processo de expansão do grupo Light (que começa a sair dos limites geográficos da cidade de São Paulo) e por outro a constituição mais clara de alguns grupos nacionais a explorar o fornecimento de energia por meio de empresas de âmbito municipal.

Não é difícil imaginar a rápida expansão da Light a partir de alguns dados sobre o desenvolvimento de seu capital: originalmente de seis milhões de dólares, em 1907 já foi elevado a 8.500 .000 dólares e no ano seguinte (1908) a 10.000.000 de dólares. A forma pela qual se dava esse aumento do capital da empresa indica que ele era autofinanciado (e não decorrente de lançamento de ações no mercado) (SAES, 1986, p. 174-175).

O aumento de capital da Light tinha sua contrapartida na crescente capacidade de produção energética instalada e a crescente importância do fornecimento de eletricidade para o desenvolvimento das cidades. A Light associou ao serviço de viação urbana e de iluminação pública à produção de energia elétrica. Este serviço garantiria uma escala mínima de operação, inviabilizando, de início, o fornecimento residencial amplo. Segundo Saes (1986, p. 227), "uma vez estabelecidas as usinas geradoras (térmicas ou hidráulicas), passou-se a oferecer energia para uso doméstico e também para uso industrial”.

Em 1909 a obra foi concluída e ficou conhecida, nesse período, como represa de Santo Amaro, pois pertencia ao antigo município de mesmo nome. As suas dimensões impressionavam, conforme nos assegura Souza (1982, p. 73):

[...] a cerca de 2,5 quilômetros, além da então vila de Santo Amaro, tem cerca 1.600 metros de comprimento, cortando o seu eixo o curso norte-sul do vale do rio em ângulo reto. Do lado leste, a inclinação do rio é suave, ao passo que do lado oeste o terreno é íngreme e levanta-se a uma altura de 40 a 50 metros acima do rio [...] A altura máxima é de cerca de 18 metros, largura no alto, 15 metros e taludes de 1 para 2 do lado de fora e 1 para 3 do lado do tanque, represando mais ou menos 
200 milhões de metros cúbicos de água. Uma tão vasta extensão de água situada em um belo vale [...].

Tanto a represa do rio Guarapiranga quanto a usina hidrelétrica de Parnaíba, eram construções conectadas com o mesmo propósito. Marcaram o início da intervenção territorial da Light na bacia do Alto Tietê a fim de viabilizar a produção e a comercialização em larga escala de energia elétrica. Assim, o domínio da razão pelas técnicas, para o controle e uso das águas, foi transformando a paisagem e os modos de vida, alterando espaços e criando produtos graças ao advento da eletricidade em grande dimensão.

Além da demanda local que exigia novas fontes de energia, é provável, e tudo parece levar a crer, que tal situação estava ligada a uma lógica capitalista internacional de uso e apropriação do espaço, por meio de investimentos de empresas privadas vinculadas à expansão do mercado de nações do chamado Primeiro Mundo (parte da Europa ocidental e dos EUA/Canadá). Pretendia-se a maximização dos lucros em detrimento às considerações sobre os impactos sociais e ambientais causados pela construção e funcionamento de grandes sistemas hidrelétricos. Embora, não podemos deixar de omitir os progressos materiais proporcionados pela eletricidade às diversas áreas das ciências e da vida humana e, posto que não estejamos analisando neste trabalho as alterações microclimáticas proporcionadas pela massa d'água superficial criada, apontamos que tal ocorrência, em substituição ao solo exposto e a vegetação ali existentes, faz com que o clima da região sofra alterações (LOMBARDO, 2006).

No mapa a seguir (Figura 12), podemos conferir o sistema hidrelétrico espacializado no Alto Tietê. A representação cartográfica, semelhante às fotografias deste trabalho, consiste na apresentação de imagem possibilitadora de leituras, por meio de signos onde a represa Guarapiranga é o elemento central da nossa atenção. Notamos parte da rede hidrográfica que compõe a bacia do Alto Tietê com as manchas urbanas dos municípios de São Paulo e Santo Amaro. À noroeste da Capital paulista temos o reservatório de Parnaíba no rio Tietê e a sua usina geradora de energia hidrelétrica juntamente com a representação das linhas de transmissão de energia elétrica, da usina em sentido à Capital. Conforme Souza (1982, p. 88), "a linha de transmissão para São Paulo, via Parnaíba, foi construída em torres de aço galvanizado com dois circuitos de 
cabos de cobre de seis condutores, com alma de cânhamo [...]" em faixa de propriedade da Light.

Em sentido leste-oeste, acompanhando em grande parte o vale formado pelo Tietê, e atravessando a cidade de São Paulo, encontra-se a estrada de ferro SantosJundiaí, imprescindível para o desenvolvimento econômico da região. Tem-se ainda representado no mapa, a pequena estrada de ferro da Companhia Carris de Ferro que ligava o sul de São Paulo a Santo Amaro.

Ao sul do mapa encontramos a bacia imbrífera ${ }^{34}$ da represa do rio Guarapiranga, compondo uma área de $648 \mathrm{~km}^{2}$ e formada por uma densa área de drenagem, destacada como as principais: o ribeirão das Lavras, o ribeirão da Taquaxiana, o rio M'boy Mirim e o ribeirão da Ressaca, todos na margem esquerda do rio Guarapiranga; o ribeirão dos Parelheiros localizado na margem direita.

Este mapa possibilita a visualização da localização geográfica dos principais elementos físicos e humanos que contribuíram para a construção da represa, que são: os rios Guarapiranga e Tietê, embora haja imprecisão na representação quanto à foz do Guarapiranga no rio Pinheiros, para posterior chegada de suas águas no Tietê; a cidade de São Paulo e a usina hidrelétrica de Parnaíba. Todos esses componentes articulados entre si e juntamente com a ação dos agentes políticos, econômicos e sociais, aliados às técnicas de apropriação territorial, promoveram uma grande alteração na paisagem, a qual foi registrada por imagens, permitindo uma interpretação mais expressiva da transformação espacial.

\footnotetext{
${ }^{34}$ A bacia imbrífera é aquela formada por uma rede hidrográfica inundável durante o período chuvoso.
} 
Figura 12 - Mapa da localização da bacia hidrográfica que forma a represa de Santo Amaro (atual Guarapiranga). Escala: 1: 250.000

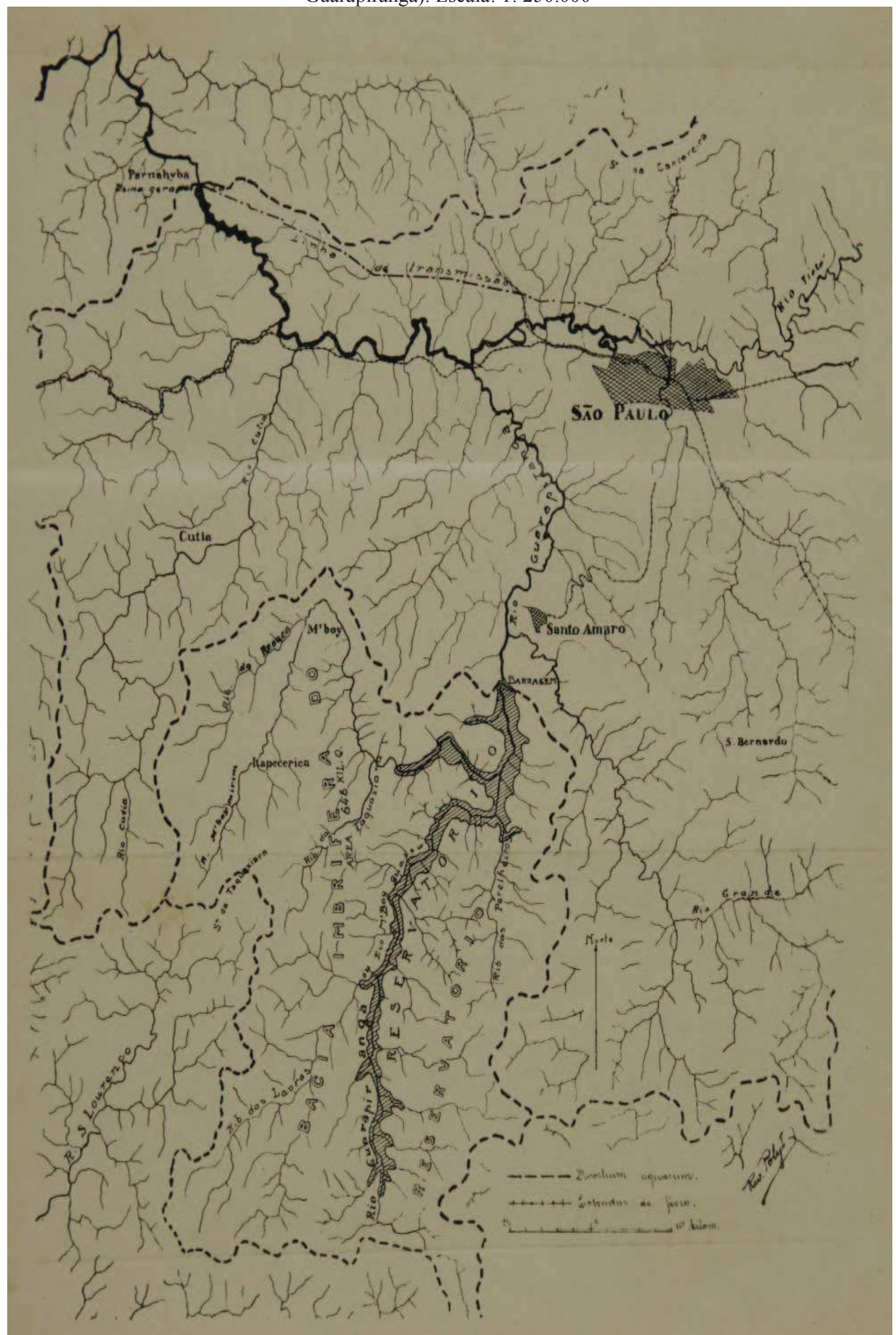

Fonte: Revista Polytechnica, São Paulo, v. 4, n. 21, p. 135, abr.-maio, 1908. 
Com a construção da represa, a porção sul de São Paulo passou por diversas transformações e novas formas de ocupação do solo e de atividades econômicas surgiram como causa direta da represa, como a criação de clubes, bares e a intenção de criação de grandes cassinos. Esse potencial turístico e recreativo fez com que a Light instalasse uma linha de bondes para o transporte de passageiros, ligando, em 1913, o centro de Santo Amaro ao centro de São Paulo.

O represamento tornou-se centro de excursões facilitado pela linha de bonde que substituiu o primitivo trem. "Em volta desse grande lago foram surgindo residências de recreio. Vieram barcos, clubes náuticos e, aos domingos, era enorme o número de pessoas que ali vinham descansar" (BERARDI, 1981, p. 98).

Salientamos, como nos lembra Berardi (1981), que desde 1886, com a inauguração do trem a vapor entre São Paulo (Vila Mariana) até Santo Amaro, já ocorria o deslocamento de pessoas desejosas de passeios, sobretudo nos dias festivos como as Festas do Divino, além de vislumbrarem um feito histórico para a época: o trem a vapor.

A inauguração da usina hidrelétrica de Parnaíba, em 1901, foi o passo decisivo para a Light estender suas linhas de bondes, fornecer energia para as indústrias e disputar, posteriormente, a iluminação pública da cidade de São Paulo com a Companhia de Gás.

Em 1901, a companhia também inaugurou a primeira linha eletrificada de transporte urbano com os bondes, decisivos não apenas para a expansão da cidade, mas sobretudo como forma de agregar valor à terra, participando de maneira decisiva na crescente especulação imobiliária, expandindo a cidade de acordo com seus interesses e de grupos a ela associados. Nesse processo, foram criados grandes vazios ao longo das linhas de bondes, que se viam repentinamente valorizados, não apenas pelo transporte, mas por todos os serviços controlados pela Light (SILVA, 2008, p. 88).

Até então, o monopólio dos transportes urbanos era da Companhia Viação Paulista, que utilizava bondes de tração animal. A Light, para obter a concessão das linhas para eletrificá-las, passou a pressionar a Viação Paulista na tentativa de adquirir suas dívidas, mas somente depois de uma longa batalha judicial é que adquiriu o controle da empresa, em 1901, em um leilão. Quanto à Companhia de Água e Luz de São Paulo, esta foi adquirida por meio da compra do controle acionário da empresa, efetivada um ano antes, em 1900. Entretanto, a grande concorrente era a Companhia de 
Gás (San Paulo Gas Company Ltd.) que detinha o monopólio da iluminação pública na área central da cidade e que não conseguiu superar a maior luminosidade das novas lâmpadas elétricas e o poder político da Light, apesar de ser a empresa responsável, desde 1872, pela iluminação pública a gás na cidade de São Paulo (SILVA, 2008, p. 3839). Esta, além de possuir maior suporte financeiro em relação às demais concorrentes da Light e ser organizada em Londres, estava protegida por contrato que lhe concedia o monopólio na área de iluminação pública em determinadas áreas da cidade, embora o documento não impedisse a iluminação por qualquer outro sistema, tal ocorrência possibilitou a expansão da iluminação elétrica pela Light em São Paulo (CARVALHO, 2003).

Mas foi a possibilidade de exploração do serviço de transportes eletrificados que inicialmente atraiu a atenção para a formação da Light, pois já possuía, por parte de seus fundadores, experiência na exploração dos serviços de transporte eletrificado e na construção de ferrovias, sendo assim os bondes uma das primeiras formas da companhia explorar a eletricidade.

Como vimos, as inovações técnicas acabavam por desbancar outros equipamentos que não acompanhavam tais revoluções tecnológicas, como o caso da eletricidade na produção de energia para a iluminação e força motriz. Mas, conforme Silva (2008), em 1907 o uso industrial de energia era de apenas 5\%, uso este que foi se elevando ao longo do tempo, conforme pesquisa de Saes (1986):

A tendência ao uso de energia elétrica nas indústrias parece bem clara a partir de dados dos censos de 1907 a 1920. Assim, para 1907, as indústrias registradas pelo censo utilizavam a potência de 109.284 H.P. dos quais $73 \%$ eram produzidos por vapor, $22 \%$ por energia hidráulica e apenas $5 \%$ por eletricidade. Já em 1920, de 310.424 H.P., 47,2\% provinha de energia elétrica, $36,2 \%$ do vapor, $7,7 \%$ de turbinas hidráulicas, $5,3 \%$ de motores de combustão interna, $2,7 \%$ em rodas d'água e $0,9 \%$ em outros motores.

Se considerarmos que em 1907 a energia elétrica ainda dava os primeiros passos no Brasil [...], parece significativo o avanço registrado até 1920 [...] (SAES, 1986, p. 227-228).

Em fins da década de 1920, com o considerável aumento demográfico na região de São Paulo, a represa passou a ser utilizada, também, como reservatório para o abastecimento de água, formando, em 1929, o Sistema de Abastecimento do 
Guarapiranga, o segundo em capacidade de produção de água da Capital do Estado, atrás apenas do Sistema Cantareira (SABESP, 2008).

A companhia Light atuou sobremaneira para a produção de energia elétrica por meio do domínio do uso das águas da bacia do Alto Tietê, conforme análise a partir da construção da barragem de Parnaíba, cerne para a edificação da represa Guarapiranga, foi invariavelmente exitosa e representava o resultado de um conjunto de fatores que se relacionavam, tendo, também, "o uso do discurso científico - que seduzia a classe política local [...]" e o poder político da empresa na maneira de "compreender e usar a forma local de se fazer política e de se dispor da coisa pública [...] manobrou sempre para que a coisa pública fosse objeto de seus interesses privados" (SÁVIO, 2015, p. 128).

A Light era detentora de um produto muito valioso: a energia elétrica e determinava a transformação do espaço urbano, participando ativamente de movimentos de especulação imobiliária em benefício próprio (e de seus acionistas). A companhia tinha autonomia para desapropriar às suas expensas áreas de seu interesse, a título de utilidade pública, com a finalidade de construir depósitos de materiais, estacionamentos de máquinas ou outras funções, chegando a sofrer taxação de parte de seu imenso patrimônio por falta de muros ou por não se encontrar edificado, indicando com isso que parte das terras era pura reserva de valor (ROLNIK, 2003).

Durante toda a República Velha, o Estado e o Município transferiam boa parte de seus serviços de infraestrutura para a iniciativa privada, passando a partir desse momento a obedecer exclusivamente à lógica e à racionalidade de tais companhias.

O consumo privado de energia elétrica era privilégio de uma ínfima parcela de abastados, uma vez que a Light exigia uma taxa mínima de consumo para realizar a instalação, embora existisse uma lei determinando a distribuição de força e luz na cidade e prevendo a obrigatoriedade do fornecimento da eletricidade a todos que solicitassem, desde que o consumo fosse superior a determinada quantidade de watt (W). Vemos que tal condição favorecia a empresa (ROLNIK, 2003).

Consolidava-se, assim, a produção e fornecimento de energia elétrica em grande escala, cujo aproveitamento hidráulico para a produção de eletricidade tornava-se a principal matriz energética brasileira. 


\section{3 - O ACERVO DA LIGHT: PAISAGEM E FOTOGRAFIA}

\section{1 - Paisagem: revisitando conceitos}

O conceito de paisagem na constituição de um espaço geográfico é amplo, mas de um modo geral, a paisagem representa uma porção da configuração territorial possível de visualização. Para Santos (2002, p. 103), a paisagem "é o conjunto de elementos naturais e artificiais que fisicamente caracterizam uma área. A rigor, a paisagem é apenas a porção da configuração territorial que é possível abarcar com a visão".

A paisagem é dotada de construções sociais, históricas, econômicas, políticas e culturais, juntamente com as contradições existentes que se entrelaçam nessas diferentes esferas do conhecimento para compor aquilo que visualizamos na configuração territorial e formar o espaço geográfico que contém a materialidade e a vida que o anima.

O espaço geográfico é organizado em função de múltiplos fatores, alguns dos quais ligados às necessidades e aspirações da sociedade. Este espaço diferenciado e localizável reflete-se na paisagem (DOLLFUS, 1982).

Segundo Claval (2004), o termo paisagem surgiu no século XV, nos Países Baixos, sob a denominação de landskip. Aplicava-se às pinturas de quadros que apresentavam, segundo ele,

um pedaço da natureza, tal como a percebemos a partir de um enquadramento - uma janela [...] Os personagens têm aí um papel apenas secundário. A moldura que circunda o quadro substitui, na representação, a janela através da qual se efetuava a observação (CLAVAL, 2004, p.13).

Claval (2004) nos assegura que o emprego do termo holandês foi imposto pela difusão do novo gênero pictural e é corroborado por Zanirato (2014) ao dizer que o conceito do vocábulo paisagem vem das artes quando a representação da natureza era expressa por artistas e que seu conceito é uma construção da cultura ocidental, estando fortemente arraigada ao ambiente natural pouco alterado pela ação do homem do século XV. 
Esse sentido, conforme a autora, permaneceu até fins do século XVIII,

quando ganharam corpo formulações acadêmicas sobre a natureza, considerada um ente passivo, que deveria ser investigada pelos critérios das ciências, em busca de sua regularidade e melhor aproveitamento. Em função disso, outros olhares além dos artistas, se voltaram para a natureza, em busca de entendimentos e explicações sobre o que podia ser uma paisagem (ZANIRATO, 2014, p. 295).

Holzer (1999) também faz uma apresentação da origem do termo paisagem. Segundo ele, 'paysage', do francês,

tem sua origem no radical 'pays', que na Idade Média francesa significava simultaneamente 'habitante' e 'território'. Logo a geografia francesa apropriou-se da palavra 'paysage', destituindo-a do seu sentido renascentista, e restituindo-a o sentido mais amplo de seu correlato alemão.

'Landschaft' [em alemão] se refere a uma associação entre o sitio e os seus habitantes, ou se preferirmos, de uma associação morfológica e cultural.

É importante mencionar que 'paysage' surge na França em 1551; 'paesaggio', na Itália do século XVII; 'paisaje', na Espanha em 1708; e 'paisagem' em Portugal, pelas mãos de Luis Mendes de Vasconcelos ${ }^{35}$, em 1608 (HOLZER, 1999, p. 152-153).

O conceito de 'paisagem', inclusive para o senso comum do pensamento ocidental, reduzia-se a uma porção do espaço que podia ser observada com um golpe de vista (HOLZER, 1999, p. 150).

A geografia, no entanto, produziu uma reflexão conceitual própria que tem como objeto de estudo a paisagem. No início do século $\mathrm{XX}$, muitos geógrafos seguindo uma tradição romântica surgida a partir do final do século XVIII, com a apreensão da natureza pintada em telas, associavam a paisagem às porções do espaço que se destacavam visualmente em suas características físicas e culturais (GANDY, 2004).

Essa visualidade, para Holzer (1999), está associada não só à observação do pesquisador em campo, mas a todo aparato técnico que permitia a projeção e identificação de áreas em uma carta geográfica. Há assim uma associação de novas

35 Luís Mendes de Vasconcelos (Lisboa, c.1550 - Malta, c. 1630): Foi um militar, político e escritor português. 
técnicas de representação do espaço. A essa bidimensionalidade visual são adicionadas as interpretações do espaço dado pelo pesquisador.

Nessa perspectiva, o conceito de paisagem está em seu sentido de formatar a Terra, sendo necessário, no entanto, considerações a partir das mudanças ontológicas que vem se refletindo na revisão dos fundamentos da geografia e de outras disciplinas (HOLZER, 1999, p. 165).

Conforme Zanirato (2014), podemos dizer que a geografia incorpora o termo paisagem em seus trabalhos, pois está muito relacionada ao espaço geográfico. Isso levou o geógrafo alemão Alexander Von Humboldt (1769-1859), também citado por Holzer (1999), a formular, no século XIX, um conceito de paisagem na perspectiva da ciência e tornando-a uma preocupação explicativa ligada às formas de apropriação do espaço.

A visão de Humboldt sobre a paisagem correspondia a uma interação de elementos que a criavam,

[...] indo ao encontro das exigências do homem total da época iluminista, em que o artista-cientista é capaz de colocar a sensibilidade em colaboração com a razão e em que a representação visível desempenha papel ativo na organização do conhecimento científico (BELUZZO, 1994, p. 10)

A melhor definição, ao nosso ver, para o conceito geográfico de paisagem é aquela que consiste não ao que é visto, mas na inserção do homem ao mundo em uma relação social, assim, a

[...] paisagem em seu sentido renascentista de 'espaço que se observa de um golpe de vista' é associada pela geografia à 'cena', enquanto que o conceito geográfico do final do século XIX voltou-se para o significado medieval de área fisicamente e culturalmente reconhecível (HOLZER, 1999, p. 153).

Os geógrafos sempre se interessaram pela paisagem, desde o início dos seus estudos, onde havia a preocupação na descrição dos fenômenos naturais. A ideia de paisagem era tida na interface atmosfera/litosfera - hidrosfera, como suporte da biosfera. Posteriormente soma-se à paisagem a interface homem/natureza (CLAVAL, 2004).

Assim, "a distribuição dos homens, suas atividades e suas obras na superfície da terra é muito fascinante e torna-se um dos principais domínios da pesquisa nos anos 
1880 e 1890”. Por volta de 1900 a geografia é definida como uma ciência das paisagens e "o privilégio dado ao olhar é confirmado". Utilizavam-se nos trabalhos as gravuras, para reafirmar e atender a uma preocupação descritiva, pois as palavras não eram suficientes para traduzir a fisionomia de um local (CLAVAL, 2004, p. 16-22).

Notamos mais uma vez a importância das imagens que, quando associadas ao discurso narrativo, são fontes de expressão do conhecimento elaborado, especialmente quanto à paisagem, que sempre esteve associada ao visual. Para Castro (2002), sendo a paisagem o que se vê,

ela supõe necessariamente a dimensão do real concreto, que se mostra, e a representação do sujeito, que a codifica no ato da observação. A paisagem como fruto dessa observação resulta de um processo cognitivo, mediado pelas representações do imaginário social, pleno de valores simbólicos (CASTRO, 2002, p. 122).

Há uma dualidade da paisagem, expressa entre o real e a representação, permitindo que a sua manifestação concreta se ofereça a uma análise que a localiza, a mensura, a classifica e a descreve. Para o autor, impõe reconhecer que a paisagem

existe primeiro em sua relação a um sujeito coletivo: a sociedade que a produz, reproduz e a transforma em função de uma certa lógica. Nesse sentido ela [a paisagem] exprime uma civilização, é uma marca, uma geo-grafia, ou seja, uma escrita no espaço e tem de ser interpretada no contexto histórico das sociedades" (CASTRO, 2002, p. 123, itálico do autor).

A paisagem vai além do real oferecido, embora ela o incorpore em uma dimensão política produto de decisões e ações humanas resultantes dos interesses, geralmente econômicos, em um dado momento, como a escolha do local para a construção da represa Guarapiranga e as suas funções para aquele momento, ocasionando muitas vezes conflitos nas sociedades de classes, onde, as "classes abastadas têm sempre melhores chances de se impor" (CASTRO, 2002, p. 133).

A nossa percepção das formas que estão e operam no mundo passa pelos nossos sentidos sensoriais e a visão, dentre outros, permite e conduz à diversas informações do meio que nos cerca. Os elementos da natureza, como os rios; as construções, como a 
represa e as cidades - transformam-se em imagens pelo olhar de quem as captou e são representações de um determinado espaço geográfico a ser interpretado.

A paisagem deve ser tratada como um processo cultural, pois não há paisagem sem um observador e a percepção visual é uma condição fundamental para a sua existência cultural.

Nesse sentido atribuímos à paisagem um papel articulador de integração entre a natureza e o homem. Conforme Meneses (2002), uma atribuição semelhante foi dada ao conceito de espaço, embora não sejam sinônimos. Santos (2002, p. 103), em seu livro intitulado A natureza do espaço: técnica e tempo, razão e emoção, nos diz: "a paisagem é o conjunto de formas que, num dado momento, exprimem as heranças que representam as sucessivas relações localizadas entre o homem e a natureza. O espaço são essas formas, mais a vida que as anima". E, ainda: “Cada paisagem se caracteriza por uma dada distribuição de formas-objetos, providas de um conteúdo técnico específico. Já o espaço resulta da intrusão da sociedade nessas formas-objetos".

As formas-objetos para o autor referem-se ao aspecto visível e o arranjo deles na constituição de um espaço. A paisagem, destarte, para Meneses (2002),

deve ser considerada como objeto de apropriação estética, sensorial. Consequentemente, não se pode negar que ela tenha uma natureza objetiva, que seja um objeto. É, sem dúvida, uma forma, mas não se define por esse caminho. É material, real, que se dá à percepção. Porém, considerá-la antes de mais nada como objeto [...] é ainda permanecer num horizonte restrito, que não seria suficiente para dar conta de todas as dimensões do fenômeno. A coisa percebida e sua representação (conceitual, visual, verbal etc) existem simultânea e simbioticamente (MENEZES, 2002, p. 32).

Quanto à representação da paisagem, Menezes (2002, p. 34-35) assinala ser um fenômeno social percebido e operado pela sociedade onde muitas vezes tanto a paisagem e a representação se equivalem, mas somente no senso comum, particularmente quando o suporte é uma imagem como a fotografia.

Assim, resumidamente para o autor, a paisagem "é produto e simultaneamente vetor das formas pelas quais a sociedade se produz e reproduz historicamente" (MENEZES, 2002, p. 38, itálico do autor).

Tal definição é muito similar a de Sauer (2004) quando, muito influenciado pela antropologia americana da época, definiu pela primeira vez uma Geografia Cultural nos 
Estados Unidos, na primeira metade do século XX, iniciando seus trabalhos sobre a paisagem e refletindo sobre os problemas colocados pela dispersão espacial e histórica dos elementos culturais. Para ele a paisagem tem o significado de forma na qual há um processo de modelagem por meio de uma composição associativa distinta, ao mesmo tempo físicas e culturais, onde por trás dessas formas existem o tempo e as causas.

Assim, para se entender a natureza de uma área, como aquela constituída pela represa Guarapiranga, devemos aprender a vê-la como uma unidade orgânica, na qual há uma correlação entre os seus elementos constitutivos.

A paisagem geográfica, conforme Sauer (2004), não é simplesmente uma cena real vista por um observador, ela é uma generalização derivada da observação de cenas individuais. Assim, o pesquisador tem em mente o genérico e procede a sua análise por comparação, atentando que

toda paisagem tem uma individualidade, bem como uma relação com outras paisagens, e isso também é verdadeiro com relação às formas que compõem a paisagem. Nenhum vale é exatamente igual a outro vale; nenhuma cidade uma réplica exata de outra cidade. Na medida em que essas qualidades estejam completamente não relacionadas, elas permanecem fora do alcance de tratamento sistemático, além daquele conhecimento organizado a que chamamos ciência (SAUER, 2004, p. 24-25).

Para o autor, a ciência não pode permanecer em nível de mera percepção. Uma ciência descritiva como a botânica não se contenta em observar o singular de uma planta. Ela se eleva a conceitos de espécie, gênero, família, ordem, classe e assim por diante. Inicialmente a geografia era idiográfica (descrevia o espaço meramente como tal), mas há muito se tornou nomotética (que se baseia em um sistema). Para o estudo da paisagem ter o seu valor científico, ele deverá ter a sua definição organizada e relacionada a outras relações causais e leis naturais (SAUER, 2004, p. 25).

Essa questão da compreensão nomotética da paisagem pode ser melhor explicada por Bobek e Schmithüsen (2004), quando discorrem sobre o conceito de conteúdo total de um espaço:

O objeto da investigação geográfica é o espaço lito-bioatmosférico da superfície terrestre em seu conteúdo e configuração totais, tanto no conjunto como em suas divisões. A geografia não se limita à observação e à descrição do visível, 
ainda que parta delas, mas pretende compreender a natureza do conjunto dos elementos constitutivos (BOBEK; SCHMITHÜSEN, 2004, p. 75).

A atuação do homem e do tempo na diferenciação da paisagem é fundamental, pois não se pode "formar uma ideia de paisagem a não ser em termos de suas relações associadas ao tempo, bem como suas relações vinculadas ao espaço" no seu constante desenvolvimento (SAUER, 2004, p. 42).

Sauer (2004) ainda pormenoriza a paisagem, dividindo-a em natural e cultural. Para ele a paisagem natural está associada ao que ele chamou de bases genéticas primárias, correspondendo aos elementos naturais como o clima, rocha (solo) e vegetação. A paisagem natural está sendo submetida a uma transformação pela ação humana, por meio das suas culturas que faz uso das formas naturais, em muitos casos alterando-as, em outros as destruindo. Essa ação do homem cria a paisagem cultural, que corresponde a todas as obras humanas em uma área geográfica e caracterizando a paisagem como um todo, podendo haver uma sucessão de paisagens de acordo com a sucessão de culturas, "com o homem expressando seu lugar na natureza como um agente distinto de modificação [...] A paisagem cultural então é sujeita à mudança pelo desenvolvimento da cultura ou pela substituição de culturas" (SAUER, 2004, p. 43).

Finalizamos o apontamento de Sauer (2004) evidenciando a importância dos materiais fornecidos pela paisagem natural na formação da paisagem cultural, a qual necessita da força modeladora da cultura, frisando que "dentro dos amplos limites do meio físico da área há muitas escolhas possíveis para o homem” (SAUER, 2004, p. 59).

Os aspectos culturais da paisagem também são discutidos por Cosgrove (2004), que diz ser a paisagem 'uma 'maneira de ver', uma maneira de compor e harmonizar o mundo externo em uma 'cena', em uma unidade visual”' (COSGROVE, 2004, p. 98).

Salientamos que divisões entre cultura e natureza são questionáveis há muito tempo pela antropologia. Santos (2002) sugere a ideia do híbrido, na qual se fundem o social e o natural e onde a forma e o conteúdo do espaço não podem ser analisados separadamente a fim de se capturar as alterações produzidas, em nosso caso, pelas dimensões fotográficas.

A partir do momento em que o homem olhou para uma paisagem ela deixou de ser natural para ser humanizada, passa a ser uma representação do que o olhar traz e que depende dos atributos culturais do observador. 
Paisagem e espaço são conceituações distintas, embora relacionais. "O espaço é a sociedade, e a paisagem também o é. No entanto, entre espaço e paisagem o acordo não é total, e a busca desse acordo é permanente; essa busca nunca chega a um fim" (SANTOS, 2002, p. 104). Além disso, conforme Santos (2002, p. 105):

O espaço não pode ser estudado como se os objetos materiais que formam a paisagem tivessem uma vida própria, podendo assim explicar-se por si mesmos. Sem dúvida, as formas são importantes. Essa materialidade sobrevive aos modos de produção que lhe deram origem ou aos momentos desses modos de produção.

A paisagem é um precioso instrumento de trabalho, permitindo rever as etapas do passado em uma perspectiva de conjunto, em virtude de uma imagem já imobilizada. São as suas formas no espaço que realizam as funções sociais presentes, por meio da sociedade que anima essas formas, atribuindo-lhes um conteúdo (SANTOS, 2002).

A técnica também está integrada ao meio como uma realidade unitária, decorrendo nesse espaço híbrido. No entanto, as técnicas são difundidas e implantadas seletivamente sobre o espaço e devem ser compreendidas em relação a ele pois,

[...] Na realidade, toda técnica é história embutida. Através dos objetos, a técnica é história no momento da sua criação e no de sua instalação e revela o encontro, em cada lugar, das condições históricas (econômicas, socioculturais, políticas, geográficas), que permitiram a chegada desses objetos e presidiram à sua operação.

[...] Cada objeto é utilizado segundo equações de força originadas em diferentes escalas, mas que se realizam num lugar, onde vão mudando ao longo do tempo (SANTOS, 2002, p. 48).

Santos (2002) procura mostrar, também, a diferença entre os conceitos de espaço e paisagem por meio de um pequeno enredo, nos dizendo que durante a Guerra Fria os laboratórios do Pentágono (EUA) chegaram a cogitar a produção de uma bomba de nêutrons, capaz de exterminar a vida humana em uma área atacada, mas preservando todas as construções. Tal projeto não foi levado a cabo pelo Presidente Kennedy. "Senão, o que na véspera seria ainda o espaço, após a temida explosão seria apenas 
paisagem", com isso afirma-nos que não há melhor imagem para diferenciar os dois conceitos (SANTOS, 2002, p. 106, itálico do autor).

O espaço, como realidade, é total e deve ser considerado como indivisível. Cada ponto do espaço é solidário aos demais em todos os momentos, a isso, Santos (2014, p. 85-86) chamou de totalidade do espaço.

Conforme o autor, temos de um lado um conjunto de objetos geográficos distribuídos sobre um território, constituindo a sua "configuração geográfica ou sua configuração espacial e a maneira como esses objetos se dão aos nossos olhos, na sua continuidade visível, isto é a paisagem"; de outro lado temos "o que dá vida a esses objetos, seu princípio ativo, isto é, todos os processos sociais representativos de uma sociedade de um dado momento". Os processos citados realizam-se através de formas que adquirem uma expressão territorial, pois, "sem as formas, a sociedade, [...] não se realizaria" (SANTOS, 2014, p. 12).

Assim, a interpretação da paisagem, como produção social, deve ser feita na estrutura determinada pela interseção da história e da natureza, como na alteração espacial de São Paulo/Santo Amaro na lógica das inovações tecnológicas daquele momento, cuja matriz foi dada pela ciência e pela técnica do centro do capital e permitiram a construção da represa que transformou a paisagem.

As relações sociais existentes e as antigas formas de povoamento deram lugar a uma nova configuração do espaço e funcionavam de maneira complementar e conjunta, como verificado pelos registros fotográficos atentos às formas construídas da represa Guarapiranga e das diversas articulações que propiciaram tal arranjo espacial em um lugar já composto por outras funções.

Cada forma sobre a paisagem é criada em resposta a certas prioridades ou funções do momento da sua criação. Isso faz com que o nosso estudo aproxime-se das definições elaboradas por Santos (2002 e 2014) em consonância aos outros autores aqui expostos, que consideram a totalidade na análise do espaço.

Essa paisagem geográfica configurada no espaço é reveladora de técnicas de um tempo histórico, tão dinâmica quanto ao processo cultural que a deu origem fisicamente e a seus registros fotográficos que possibilitam discorrer e elaborar a narrativa de como os homens organizam sua sociedade no espaço e o uso que fazem dele ao longo do tempo. 


\section{2 - Lendo imagens}

As imagens fotográficas, não como segundo plano ou anexo, mas como documentos de registro qualitativo da paisagem são consideradas relevantes, principalmente se relacionadas a outras narrativas discursivas para trazerem a historicidade e a compreensão do processo de transformação de um lugar.

Embora as imagens tenham sido meios de expressão da cultura humana desde as pinturas pré-históricas em rochas e cavernas e existam muito antes do aparecimento do registro da escrita, as linguagens visuais na história das ciências eram precedidas pelos estudos nos quais prevaleciam a escrita. No entanto, aspectos trazidos pelas imagens como fontes de interpretação do mundo e no desenvolvimento científico já haviam sido observadas no século XVI com o uso da linguagem visual em estudos geológicos e geográficos, dentre outros, e conferiam o seu valor no desenvolvimento das chamadas ciências naturais. Os aperfeiçoamentos nos registros e impressão da realidade foram constantes nas técnicas e permitiram o apontamento territorial de muitos espaços a serem explorados (PATACA, 2015).

No contexto da Revolução Industrial, durante o século XVIII, as imagens, no caso desenhos, ainda funcionavam para a divulgação de técnicas a um público de trabalhadores e

[...] na intensificação do processo construtivo e na necessidade de divulgar as técnicas a públicos não especialistas. A função didática das imagens técnicas se acentua e são criadas cenas sequenciais descrevendo o processo técnico de produção artesanal e industrial, [...] (Pataca, 2015, p. 73).

Assim, as imagens ajudaram na consolidação da ciência moderna, na qual, “[...] a representação factual está repleta de conceitos que seriam impossíveis de se descrever através da linguagem verbal". Ressaltamos que para muitos aspectos e em determinadas ciências, como a botânica, a fotografia bidimensional não substitui o desenho manual, possibilitador de foco específico e tridimensionalidade (PATACA, 2015, p. 70).

A valorização da vista humana como uma expressiva ferramenta de estar e operar no mundo faz parte da essência humana. Pataca (2015) ao referir-se à história natural, que tinha a necessidade de visualizar para depois nomear os seres observados, corrobora a nossa afirmação de valorização das imagens na interpretação das paisagens 
e consequentemente na construção do conhecimento. Destarte, em um processo de compreensão textual o estímulo desencadeado pela escrita ou pela fotografia apoia-se em processos cognitivos, nos quais o

texto é toda mensagem, em qualquer tipo de linguagem: escrita, sonora, imagética, gestual. Para a compreensão, o sentido de um texto é algo que antecede o contato do leitor com o texto. Isto significa dizer que o leitor pré-existe à descoberta do significado das palavras escritas. O leitor foi se configurando no decorrer das experiências de vida, desde as mais elementares e individuais até as decorrentes do intercâmbio com seu mundo pessoal e cultural (CIAMPI, 2003, p. 8).

Provavelmente deve existir para toda a humanidade "esquemas mentais e representativos universais, arquétipos ligados à experiência comum a todos os homens", porém não podemos deduzir que a leitura imagética seja universal. Há diferenças entre percepção e interpretação fazendo do reconhecimento de um motivo não signifique que "se esteja compreendendo a mensagem da imagem na qual o motivo pode ter uma significação bem particular, vinculada tanto a seu contexto interno quanto ao de seu surgimento[...]", exigindo, assim, um aprendizado (JOLY, 2006, p. 42).

A imagem visual é um sistema simbólico desvendado pelo indivíduo em função de sua cultura e de sua história de vida, resultado da apreensão que faz do mundo e da maneira como se operam os processos de produção do sentido, cujas percepções produzem estratégias e práticas de atuação, sendo a realidade social construída e lida de acordo com os diferentes lugares e momentos, dando a inteligibilidade do sentido (CHARTIER, 2002).

Ao olharmos para uma imagem

não percebemos somente sua estrutura visual, também a interpretamos. A imagem que se oferece para leitura é uma forma de texto, cuja estrutura articula-se com elementos básicos como o contraste, a cor, o volume e o espaço que envolve as figuras (ZANIRATO, 2005, p. 27).

A afirmação anterior é corroborada por Joly (2006, p. 43), quando nos diz ser a imagem o resultado de muitas transposições, nos quais faltam muitos aspectos relevantes em sua visualidade, como: a "profundidade [...], a alteração das cores (ainda 
maior com o preto e branco), a mudança de dimensões, a ausência de movimento, de cheiros, de temperatura etc. [...]”.

A leitura da imagem requer modos de interpretação para a atribuição de sentido a elas, sendo necessário um processo pedagógico que se constrói "por meio de convenções sociais, por todo um conjunto de normas e regras comuns aos indivíduos, através das quais se constroem formas de intercâmbio dos conteúdos da realidade" (ZANIRATO, 2005, p. 18) e, ainda,

[...] a cultura modifica a percepção e cada imagem é uma espécie de texto cultural que relaciona a forma do conteúdo e o conteúdo com a estética e os significados. Ao se deparar com uma imagem o leitor realiza atos de leitura que implicam uma série de competências e habilidades: sensoriais, perceptivas, psicológicas, culturais, históricas, cognitivas, etc (ZANIRATO, 2005, p. 19).

Para Schwarcz (2014), a leitura das imagens conta e registra interpretações de fatos e serve como exercício de análise histórica de estudo de caso, como na imagem fotográfica que possibilita ao seu intérprete a investigação e a análise crítica de um fenômeno a partir de uma abordagem sociocultural, por meio da tentativa de identificação dos seus elementos constitutivos.

Contudo, as fotografias, como difusão impressa de imagens pictóricas, tornaramse tecnicamente possíveis somente na passagem do século XIX para o XX (KOSSOY, 2002) e estão inseridas no período histórico que compreende as diversas alterações paisagísticas promovidas pelo desenvolvimento das técnicas construtivas e de seus registros por meio de imagens fotográficas.

$\mathrm{O}$ advento da fotografia ocorre por meio de um processo químico, operado pelo princípio da câmara escura e entendida como um registro visual da verdade, porém "a foto não é mais do que uma impressão de verdade, que se explica em face do ato mecânico [...]" permitindo manipulações na configuração da visualidade a partir de objetos reais. Assim, “[...] os fatos registrados não se constituem em verdades, mas sim em construções humanas, em que há toda uma subjetividade implícita" (ZANIRATO, 2005, p. 19 e 21, itálico da autora).

As imagens fotográficas são produzidas por meio de uma conexão dinâmica e captação física de fragmentos do mundo visível, ou seja, dependem de um equipamento de registro e implica necessariamente, conforme Santaella e Nöth (2008), na presença 
de objetos reais preexistentes que "ao congelar pessoas, coisas ou situações em instantâneos, a fotografia funciona como um repetido testemunho de que aquele instante já passou, não mais existe, desapareceu para sempre, morreu" (SANTAELLA; NÖTH, 2008, p. 134).

A sua invenção em muito contribuiu para a preservação da memória. "Graças a ela tornou-se possível o registro de cenários, pessoas, acontecimentos com muito mais precisão e abrangência do que a memória escrita poderia fazer [àqueles que podem utilizar-se dessa linguagem]" (CORREA, 2005, p. 53).

Estamos cientes de que com o advento da fotografia houve a possibilidade da construção de imagens, de mistificação de pessoas e ambientes, tudo por meio de associações que se pretende criar. Isso também existia e existe com as pinturas e desenhos, existindo por detrás de cada imagem uma intenção político-social, conferindo uma possibilidade de análise aberta para múltiplas interpretações. No entanto, a fotografia testemunha a visão de mundo de quem a fez e neste sentido há elementos implícitos que devem ser desvendados para proporcionar dados importantes sobre o lugar e tempo de sua criação e permitirem uma melhor compreensão de aspectos envolventes na produção da imagem.

Nas primeiras fotografias de paisagem do Brasil predominavam panoramas dos conjuntos de construções que definiam povoamentos e cidades em meio à natureza. Conforme Fabris (1991, p. 161),

os fotógrafos pioneiros aparentemente interessavam-se pela paisagem brasileira de uma maneira ampla, na qual a paisagem natural e a construída pelo homem integravam-se em composições únicas. O casario, a vegetação e os recortes topográficos, eram elementos que se harmonizavam, retratando a paisagem brasileira de uma forma abrangente.

Constatamos que no início da República, no Brasil, a produção e o consenso dos apelos sensoriais aos novos discursos nacionalistas, por meio de divulgação de imagens, imprimiam o desenvolvimento da nação e de seus condutores, mostrando-se mais eficientes que a racionalidade de discursos não feitos por imagens. Para Sevcenko (1998), tal estímulo sensorial à visualidade imagética visava à comunicação e a construção de um ideário nacional à uma população majoritariamente iletrada. Para se ter uma ideia, segundo Costa (2010, p. 258), na cidade de São Paulo, “[...] o índice de 
alfabetização, que andava próximo aos 5\%, em 1835, atingia 35\%, em 1872, e 45\%, em 1887, quando o Estado [de São Paulo] apresentava um índice de 29\%”.

Os componentes estruturais ou elementos constitutivos de uma fotografia são os que a tornam possível e materialmente existente e, para tanto, é necessário se ter

[...] o assunto (em função de uma determinada finalidade/intencionalidade) que é o objeto de registro, a tecnologia que viabiliza tecnicamente o registro e o fotógrafo, o autor quem, motivado por razões de ordem pessoal e/ou profissional (de aplicação científica, educacional, jornalística, comercial, dentre outras), a idealiza e elabora através de um complexo processo cultural/estético/técnico, processo este que configura a expressão fotográfica. Tal ação ocorre num preciso lugar, numa determinada época, isto é, toda e qualquer fotografia tem sua gênese num específico espaço e tempo, suas coordenadas de situação (KOSSOY, 2002, p. 25-26, itálico do autor).

Portanto, em uma imagem fotográfica há a associação de componentes de ordem material, que são os recursos técnicos, e os de ordem imaterial, que são os culturais. Para Kossoy (2002), todas as fotografias são representações a partir do real, ou seja, representam realmente um cenário, mesmo que este seja forjado e sirva apenas para encenação, mas é o real daquele instante registrado, como também nos afirmam Santaella e Nöth (2008) e Joly (2006).

Com o desenvolvimento das ciências, verificado sobretudo à partir do advento da Revolução Industrial, surge uma série de invenções e a fotografia, surgida nesse contexto, “[...] teria papel fundamental enquanto possibilidade inovadora de informação e conhecimento, instrumento de apoio à pesquisa nos diferentes campos da ciência e também como forma de expressão artística” (KOSSOY, 2014, p. 29).

Assim, muitos aspectos do espaço geográfico passaram a ter a sua memória visual registrada pelas fotografias. Esse registro fotográfico original constitui uma fonte primária, inclusive a sua transposição para o formato digital, o qual o autor assume como, também, uma fonte primária e não secundária (KOSSOY, 2014, p. 45), pois é "como um documento do real, uma fonte histórica [...] funciona sempre como documento iconográfico acerca de uma dada realidade. Trata-se de um testemunho que contém evidências sobre algo" (KOSSOY, 2002, p. 31 e 33, itálico do autor).

As fotografias oferecem múltiplas oportunidades para a interpretação de lugares e, a nosso ver, proporcionam uma recuperação da visualização de cenários que fizeram 
parte do território em época pretérita e foi alterado pelas intervenções humanas. Guianos por um período sobreposto a outro, revelando-nos aquilo que não é mais permitido enxergar, a não ser pelo vislumbre de imagens de um tempo passado, fortalecendo a compreensão do panorama das paisagens. Segundo Mendes (2016), as mudanças iniciadas intensivamente a partir do século XIX na estrutura física e na arquitetura das cidades, buscando a urbanização da paisagem, ocorreram concomitantemente ao surgimento e à incrementação do ato fotográfico. A visão da chamada modernização das cidades e o registro "imagético estático do mundo em grande mutação e desenvolvimento se imbricaram e uma relação de retroalimentação passou a acontecer", dando às fotografias condição de mercadorias sob diferentes serventias (MENDES, 2016, p. 81).

No contexto das inovações tecnológicas, podemos salientar que o advento da fotografia foi uma ferramenta de interpretação do espaço/representação, constituindo uma nova técnica para o registro das paisagens dos espaços a serem apropriados. Além disso, "a fotografia foi um dos gatilhos que favoreceu as ações de desinfecção das cidades do que era considerado feio, sujo e nada saudável, impeditivos à aparência do progresso e da modernidade" (MENDES, 2016, p. 65).

Assim, concomitantemente ao advento da fotografia, o qual confere muitos registros da vida e das paisagens, têm-se os eventos implementados no cenário urbano em virtude da suplantação ou readaptação territorial a novas situações sociais frente às técnicas produzidas.

Com a revolução no processo de produção, a criação de imagens pautou-se em novos requisitos, determinando: exatidão, rapidez de execução, baixo custo e reprodutividade (FABRIS, 1991, p. 12). Com as mudanças sociais do século XIX a informação visual foi ampliada para a propaganda política e para a publicidade comercial, fazendo das imagens um elemento recorrente aliado ao discurso narrativo.

As fotografias serviam também como representações do registro do olhar daqueles que queriam utilizá-las como fontes documentais da atuação no espaço a ser transformado. O mesmo é válido para o domínio das iniciativas do poder público e privado que as viam como documentos comprobatórios para juntada aos relatórios técnicos de intervenção no espaço; como registros das obras de construção; como material didático na utilização nos cursos de engenharias, sobretudo em um período de criação e desenvolvimento das escolas politécnicas; no fortalecimento das relações das 
empresas e suas obras com os agentes das esferas do estado, a exemplo da Light; como suporte técnico para atuações no território; como atividade profissional e como registro amador de objetos e situações.

Realçamos que na produção das imagens fotográficas, tanto o fotógrafo quanto o pesquisador que se debruça sobre a imagem para estudá-la, são seres políticos e históricos e suas concepções de mundo estão presentes tanto na elaboração quanto na análise da imagem. A fotografia é uma expressão pessoal e um registro documental da dinâmica sócio-temporal materializada de um espaço real, como já explicitado. Possui também uma dimensão artística que possibilita novos olhares. Portanto, as imagens, sejam elas fotografias, que têm todo um aparato tecnológico por detrás do seu feitio, sejam as pinturas, retratam a visão de quem as fez, com os seus repertórios culturais, motivacionais e técnicos no registro das paisagens (KOSSOY, 2014a).

A arte alia-se à ciência como ferramenta para a interpretação e constituição de saberes do mundo multidisciplinar nas suas origens e desenvolvimento, conferindo às imagens uma perspectiva na ampliação do conhecimento sobre o objeto estudado e permitindo à fotografia "[...] uma relação indivisível entre matéria e expressão; em outras palavras, entre o artefato e o registro visual, condição dual que a caracteriza" (KOSSOY, 2014, p. 81).

Assim, as narrativas imagéticas não podem ser menosprezadas, elas trazem informações relevantes para a análise de um fato e lugar. Para tanto se deve entender como a imagem foi produzida, a sua intenção, por quem, o contexto histórico e qual a mensagem explícita e tácita que ela transmite, além de como ela altera e induz leituras, sendo importantes na recuperação de informações de uma época que devem ser difundidas.

Os recursos iconográficos devem ser entendidos como fonte de pesquisa que precisam passar por uma verificação crítica e fazer com que se expanda a noção de arquivo e acervo para além das bases escritas, como nos informa Schwarcz (2014, p. 392):

[...] produzir novos conhecimentos a partir de análise de moedas, lápides, objetos de cultura material de uma maneira geral, fontes literárias, obras de teatro, telas, esculturas, imagens de jornal, cartazes, caricaturas e, tomando um lugar cada vez mais importante, fotografias. 
Porém, a autora acentua que esses tipos de materiais continuam ocupando um lugar subalterno, como se houvesse uma hierarquia interna às fontes: "[...] em primeiro lugar os registros escritos, em segundo (e de maneira distanciada) as imagens, e de maneira alargada. Mas penso que é chegada a hora de lermos imagens" (SCHWARCZ, 2014, p. 392, itálico da autora).

As imagens devem ser vasculhadas, analisadas como documentos e não como ilustrações e, ainda, "não como reflexo, mas como produção de representações, costumes, percepções e não como imagens fixas e presas a determinados temas e contextos, mas como elementos que circulam, interpelam, negociam" (SCHWARCZ, 2014, p. 393).

A fotografia para ser utilizada como fonte histórica deve associar-se a outros tipos de texto verbal e não verbal e formar a textualidade de uma época, "compreensão ampla das maneiras de ser e agir de um determinado contexto histórico, à medida que os textos históricos não são autônomos, necessitam de outros para a sua interpretação" (FIGUEIREDO, 2014, p. 113).

Existe uma complementaridade entre imagem e linguagem escrita ou oral e não uma oposição, "uma vez que a linguagem não apenas participa da construção da mensagem visual, como a substitui e até a completa em uma circularidade ao mesmo tempo reflexiva e criadora". Palavra e imagem, cada qual com sua especificidade, se completam (JOLY, 2006, p. 11).

[...] é injusto achar que a imagem exclui a linguagem verbal, em primeiro lugar, porque a segunda quase sempre acompanha a primeira, na forma de comentários, escritos ou orais, títulos, legendas, $[\ldots]$.

[...] julgamos uma imagem 'verdadeira' ou 'mentirosa' não devido ao que representa, mas devido ao que nos é dito ou escrito do que representa. Se admitirmos como verdadeira a relação entre o comentário da imagem e a imagem, vamos julgá-la verdadeira; se não, vamos julgá-la mentirosa.

[...] É a conformidade ou não conformidade entre o tipo de relação imagem/texto e a expectativa do espectador que confere à obra um caráter de verdade ou de mentira (JOLY, 2006, p. 116-117).

Nesse sentido, as imagens podem mudar os textos escritos e estes, por sua vez, podem alterar uma imagem. Texto e imagens se atravessam e se transformam. 
As imagens fotográficas "nos mostram um fragmento selecionado da aparência das coisas, das pessoas, dos fatos, tal como foram (estética/ideologicamente) congelados num dado momento de sua existência/ocorrência". Essa materialidade do registro da imagem, que ocorreu em certo tempo e espaço concretos, passa a ser o nosso referente de pesquisa, como documento e fonte histórica com potencial informativo a ser alcançado na medida em que os seus fragmentos forem contextualizados nos "múltiplos desdobramentos (sociais, políticos, econômicos, religiosos, artísticos, culturais enfim) que circunscreveu no tempo e no espaço o ato da tomada do registro. Caso contrário, essas imagens permanecerão estagnadas em seu silêncio" (KOSSOY, 2002, p. 21-22).

\subsection{Paisagens nas fotografias da construção da represa Guarapiranga}

As reproduções fotográficas pesquisadas para este trabalho referem-se a cenas que registram as etapas da construção da represa Guarapiranga e são vistas como representação de paisagens às quais atribuímos sentidos, ou seja, são cenas recortadas do espaço geográfico, o qual foi apropriado para a construção da represa, tendo as fotografias na sua origem um espaço e tempo específicos, são as suas coordenadas de situação, segundo Kossoy (2002).

As fotografias da represa Guarapiranga nos levam a compreender o processo de transformação do espaço de parte da região de São Paulo, inserida no contexto político e econômico em diferentes escalas. Os seus registros nos remetem aos discursos oficiais que se fundamentaram na técnica como possibilitadora de um processo de apropriação do território a ser conquistado, higienizado e civilizado para, enfim, adequar-se ao modelo da belle époque (SEVCENKO, 1998). O próprio registro fotográfico, por meio de equipamentos que gravam em um suporte fotossensível o vestígio e a aparência de um recorte têmporo-espacial, configurava como um meio técnico, pelo qual "as imagens podem ser observadas tanto na qualidade de signos que representam aspectos do mundo visível quanto em si mesmas" (SANTAELLA, 2008, p. 37). 
Os princípios norteadores surgidos dessa racionalidade técnica, difundindo novas condições para o desenvolvimento do capitalismo mundial, tem para Sevcenko (1998, p. 35) um efeito globalizante e iria

articular a inserção do país no contexto modernizador e propiciar a gestação de novas elites formadas pelos modelos de um pensamento científico cosmopolita. Essas elites atuariam, já na ordem republicana, como mediadoras na integração do país aos novos termos da gestão internacional do capitalismo.

Paralelamente, temos nos registros valiosas fontes para a memória do espaço, no qual a fotografia foi um "veículo importante para a construção e perpetuação dos conceitos sobre o Brasil num momento de forjamento de identidade que estava ali disposto, pela transição do Império para a República, que levou alguns anos para se estabelecer" (MENDES, 2016, p. 64).

Além do mais, o estudo das imagens é imprescindível na recuperação e entendimento da apropriação territorial, sobretudo no espaço urbano, onde as relações homem/meio são muito velozes na escala do tempo histórico.

Para Cartier-Bresson ${ }^{36}$ (1971, apud FIGUEIREDO , 2014, p. 117):

De todos os meios de expressão, a fotografia é o único que fixa para sempre o instante preciso e transitório. Nós fotógrafos, lidamos com coisas que estão continuamente desaparecendo e, uma vez desaparecidas, não há nenhum esforço sobre a terra que possa fazê-las voltar. Não podemos revelar ou copiar uma memória.

Assim, as fotografias de uma localidade são a sua descrição visual e permitemnos imprimir as composições do aparente, pois abordam elementos constitutivos da paisagem (MENDES, 2016, p. 81), como no caso dos registros da formação da represa Guarapiranga, onde a construção em si sobressai aos elementos do sítio natural, porém, os aspectos mais relevantes na composição da imagem são as suas motivações, perspectivas essas não aparentes, mas fundamentais para a efetivação do registro fotográfico da feição paisagística.

\footnotetext{
${ }^{36}$ Henri Cartie-Bresson (França, 1908 - 2004): fotógrafo e desenhista.
} 
As imagens da construção da barragem, ainda em Parnaíba (a primeira grande obra da Light no país) transformaram-se em ícones da intervenção técnica no território e iam ao encontro do discurso científico, além das fotografias da então obra permitirem à Light propagandear os seus feitos no território e possibilitarem a "multiplicação de testemunhas" das ações da empresa (SÁVIO, 2015, p. 131).

Muito do relato de Sávio (2015) acerca das imagens produzidas da construção em Parnaíba são, a nosso ver, parecidas com a construção de Guarapiranga, na qual a intervenção técnica da empresa no território acabava por alterar a fisionomia da paisagem.

$\mathrm{Na}$ composição de imagens que se segue (Figura 13), mais adiante pormenorizada, podemos compreender melhor a dimensão das obras da construção das represas e compará-las dentro de uma mesma lógica, inclusive das relações sociais evidenciadas no perfilamento das pessoas diante às construções. Esses elementos se repetem em uma narrativa por meio das imagens, embora em localidades distintas mas com uma mesma finalidade. 
Figura 13: Cópias fotográficas comparativas das construções da Light em Santana de Parnaíba (1900) e Santo Amaro (1906), respectivamente
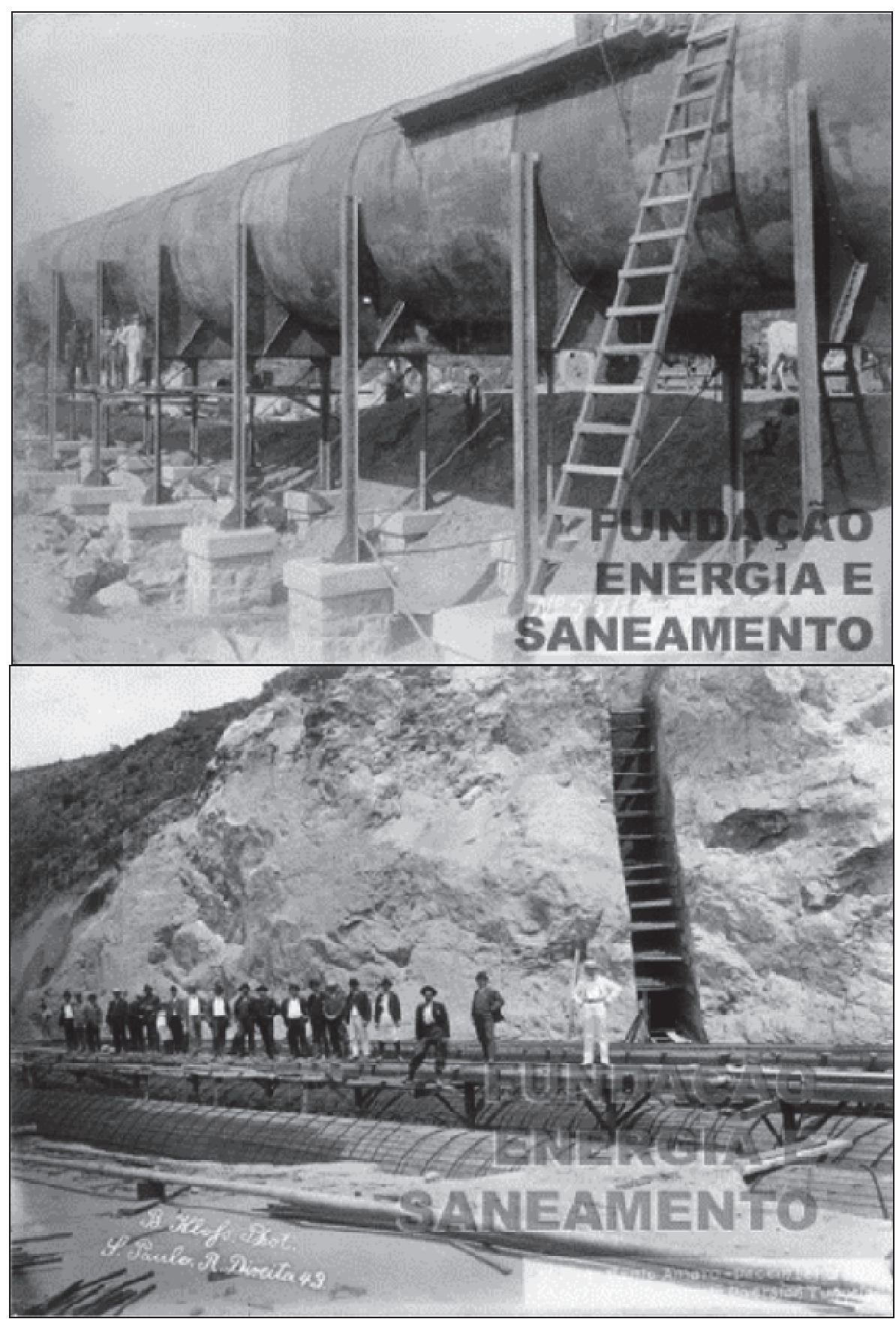

Fonte: Acervo digital da FES (2015). 
Figura 14 - Cópia fotográfica. Construção da represa de Santo Amaro (atual Guarapiranga). Reforço de concreto dos túneis de desvio, 1906

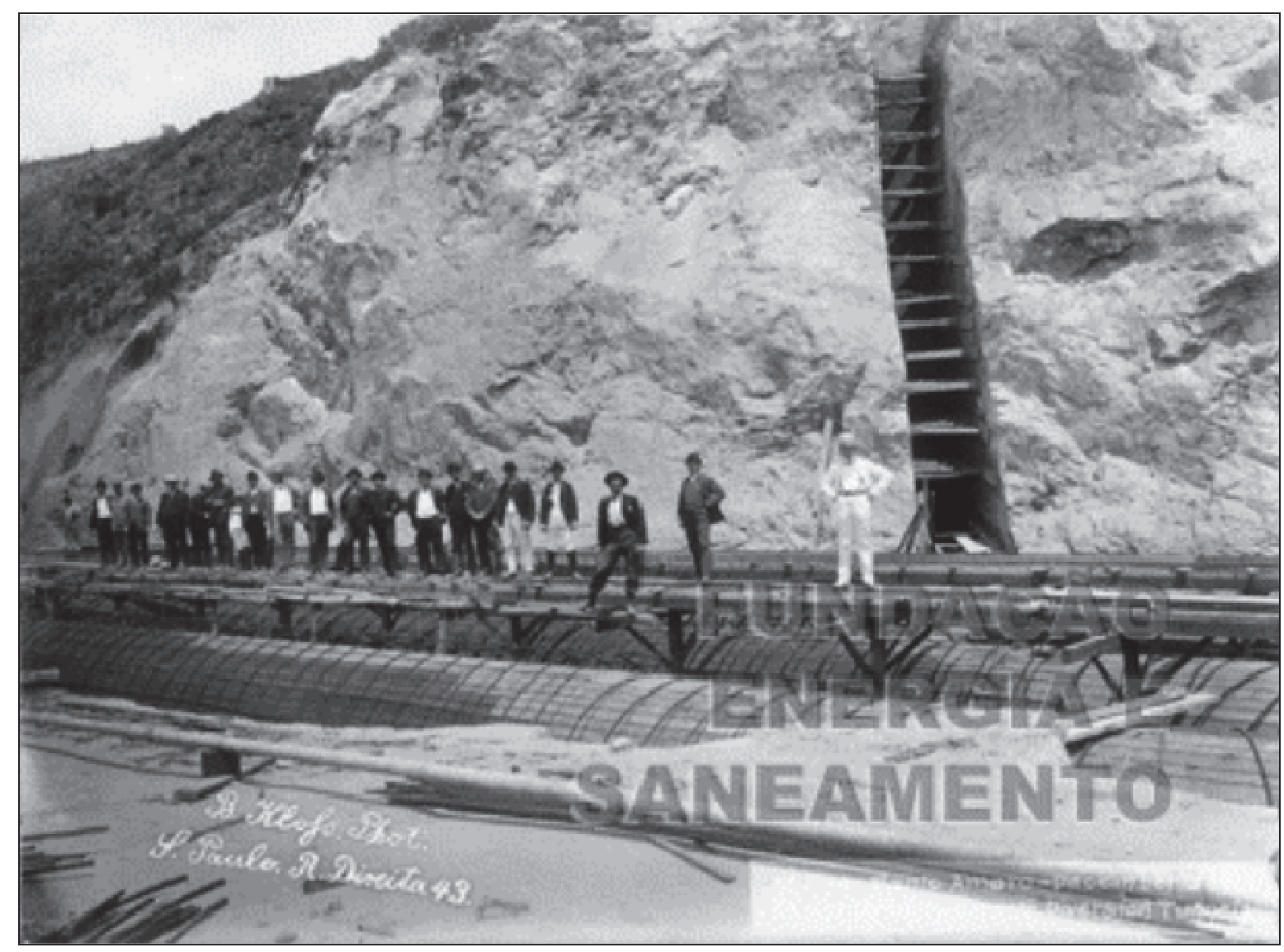

Fonte: Acervo digital da FES (2015). Original: 16,5 x 22,5cm [ELE.CEI.SAM.001.1029]

A cópia fotográfica da construção em Santana de Parnaíba foi analisada anteriormente neste trabalho. Quanto à imagem da Guarapiranga (Figura 14) trata-se de uma cópia fotográfica em preto e branco, pertencente ao acervo digital da Fundação Energia e Saneamento, nos remete ao período de 1906, quando da construção da atual represa Guarapiranga. O seu título original em inglês, na base inferior à direita da fotografia, revela: $N^{o}$ 1029. Santo Amaro - December 2 1906. Diversion Tunnels. A foto em sua base à esquerda está autenticada pelo fotógrafo Bruno Klofs, com os dizeres: B. Klofs. Phot. S.Paulo. R. Direita 43, muito comum à época a contratação de serviços fotográficos para a realização de fotografias pessoais ou sob encomenda de empresas ou instituições ${ }^{37}$.

\footnotetext{
${ }^{37}$ Em pesquisa na Hemeroteca Digital Brasileira, na seção do Correio Paulistano, de 19.06.1906, página 3, sob número 15.385, encontramos a única referência ao fotógrafo Bruno Klofs, com distinção elogiosa do seu trabalho em São Paulo.
} 
Na imagem percebemos que o volume da foto está realçando a construção da represa, a qual observamos que para a tomada da imagem o fotógrafo posicionou-se no mesmo nível do grupo dos trabalhadores da obra, com alguns metros de distância e de maneira oblíqua em relação ao enfileiramento das pessoas posadas para a fotografia, cujo enquadramento privilegiou o grupo humano e a construção sendo realizada. Notamos a presença de um menor, provavelmente uma criança, com vestimenta de cor clara e gravata típica infantil, posicionada no sétimo lugar a contar da esquerda da fileira e somente perceptível por meio do equipamento de ampliação da imagem. A definição e a clareza somente são possíveis nas instalações da FES, que permite ampliações dos pixels e a visualização mais apurada das imagens.

A incidência da luz solar e o sombreamento proporcionado com os contratastes entre claro e escuro possibilitaram a formação da imagem representativa de parte da construção da represa.

Constatamos que no primeiro plano está o túnel de reforço e suas amarrações provavelmente em madeira e ferro. Em cima dessa estrutura está um grupo de pessoas enfileiradas e ordenadamente posam para o fotógrafo a fim de permitir o registro, dirigindo os seus olhares para a objetiva da câmera fotográfica e com pouco movimento dos personagens que aguardam a captura da imagem.

$\mathrm{Na}$ posição central da cena estão três homens, com destaque para um deles, disposto de maneira mais distanciada de todo o grupo e trajando vestimentas de cor clara, com sua figura sobressaindo em relação aos demais.

Esse homem com roupa e chapéu claros está com os braços na cintura, passando-nos a sensação de que observa a obra da qual, provavelmente, possui um papel de destaque em relação aos demais, possivelmente um engenheiro ou encarregado responsável pelo comando e gerenciamento.

No plano de fundo da cópia fotográfica nota-se, mais à direita, a construção de um corte transversal na colina, com escoras, provavelmente de madeiras, promovendo um contraste de luz entre o corte no morro, que está sombreado, apresentando-se mais escuro na revelação fotográfica em relação ao solo exposto. Mais uma vez figura-se a complementaridade no jogo de luz e percepção aos olhos, fundamental para a visualização e leitura da imagem, além da necessidade do comparativo entre reproduções distintas a nos remeter e aprofundar no entendimento de uma mesma situação a configurar o espaço. 
Ainda, no plano de fundo e no canto esquerdo da foto, vemos a representação da encosta do morro com sua vegetação provavelmente de capoeira. Tratava-se de uma área bastante desmatada anteriormente por sitiantes para a obtenção de lenha e estava passando por grande movimentação de solo, em decorrência das obras da construção da represa, tendo a vegetação original, em grande parte, desbastada, como é possível observar na comparação com outra imagem fotográfica (Figura 15), obtida na mesma época e, muito provavelmente, retratada em sequência, pois as fotos foram ordenadas uma em seguida a outra e respeitando a numeração registrada nos originais pela FES, embora invertidas na nossa narrativa, além de serem chanceladas pelo mesmo fotógrafo, conforme observado à margem inferior à direita e sobreposta à marca d'água da Fundação Energia e Saneamento. Na legenda original, também em inglês, temos: $N^{o}$ 1028 - Santo Amaro - October 13 1906. Ox teams on seraper work Sta. - 8 of dry embank men, localizada na margem inferior à esquerda.

Nesta imagem chama-nos a atenção os três homens de terno e chapéu montados à cavalo, na posição central da foto, e um deles no único cavalo de cor clara, provavelmente branco, a observar as tarefas do trabalho como o suposto engenheiro ou encarregado retratado na imagem anterior.

Há a presença de bovinos representados na imagem juntamente com o agrupamento de pessoas e no plano de fundo, à frente das silhuetas montanhosas, observamos esparsas árvores em uma tomada de imagem distanciada pelo fotógrafo na captura do seu registro. 
Figura 15 - Cópia fotográfica. Construção da represa de Santo Amaro (atual Guarapiranga). Grupo de trabalhadores com bovinos, 1906

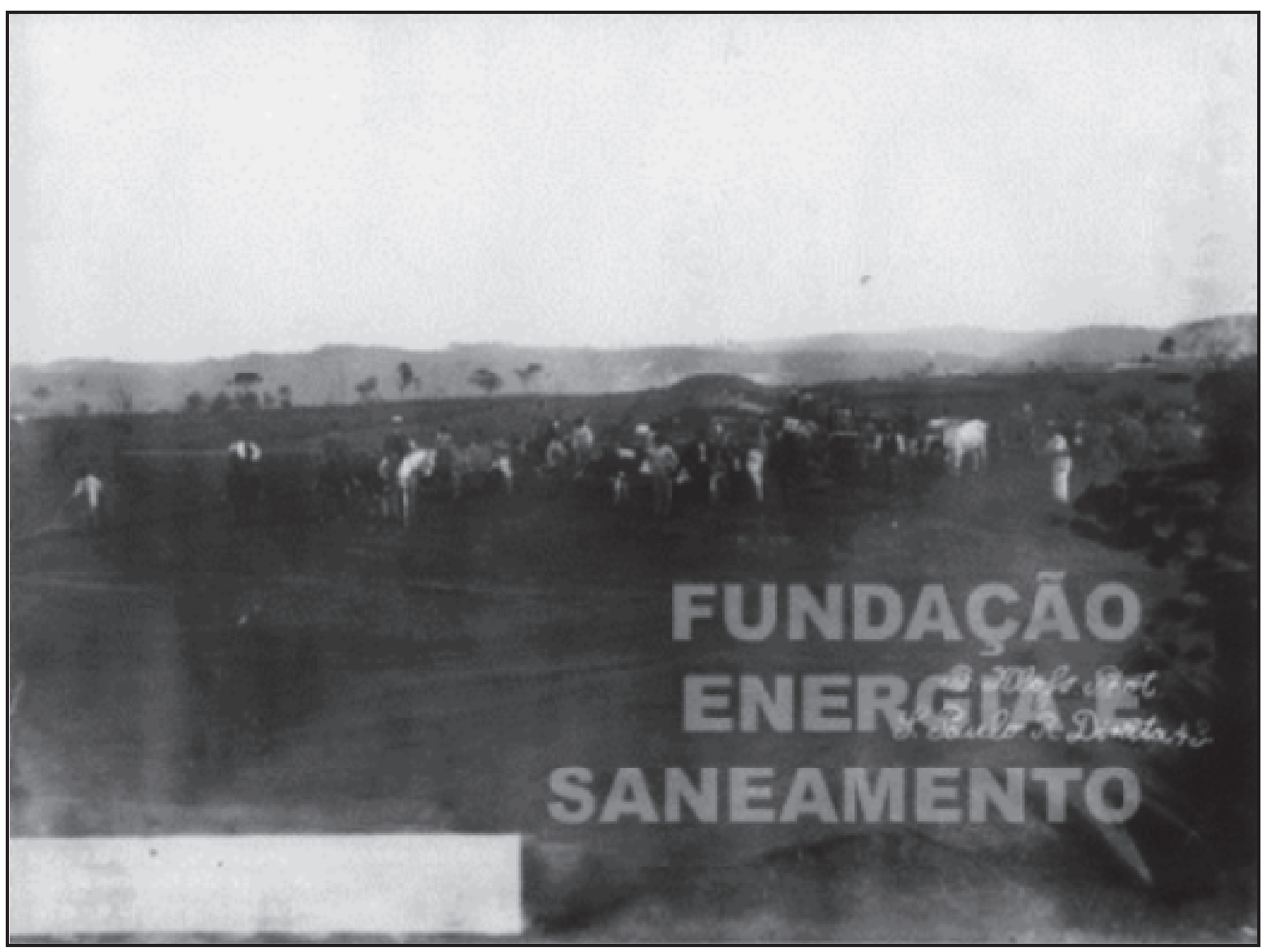

Fonte: Acervo online da FES (2015). Original: 17 x 22,5cm [ELE.CEI.SAM.001.1028]

Figura 16 - Composição de cópias fotográficas das construções da Light (Guarapiranga), 1906, com destaque para a chancela do fotógrafo B. Klofs
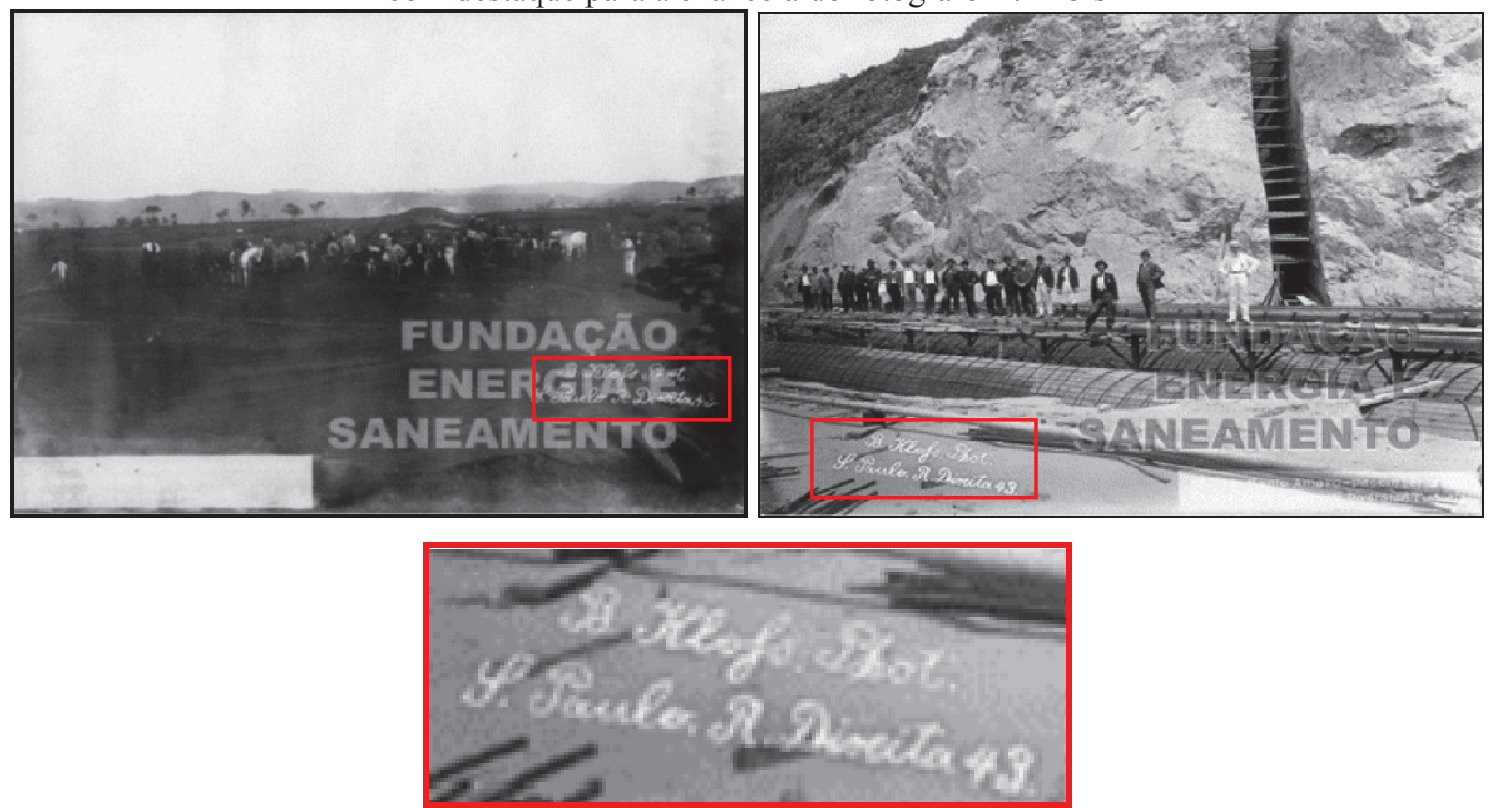

Fonte: Acervo digital da FES (2015). Diagramação do autor (2018). 
O referido fotógrafo autentica outras fotos da construção da Guarapiranga, mas não todas as imagens pesquisadas. Contudo, em observação ao período e a produção imagética estabelecida dentro de uma cronologia dos registros arquivísticos que a Light respeitava, inferimos que as fotos de Guarapiranga foram produzidas, em quase a sua totalidade por B. Klofs, um fotógrafo estabelecido em São Paulo, conforme endereço chancelado nas fotos. Não se conhece detalhes biográficos do fotógrafo, apenas que ele atuava na época na cidade, segundo indica a nota do Correio Paulistano observada nesta pesquisa.

As imagens registram a alteração paisagística efetuada pelo homem a partir da apropriação das técnicas nos diferentes momentos da sociedade e a fotografia, nos elementos que a compõe, permite a leitura do caráter simbólico expresso pelos sistemas de atitudes relacionadas às representações sociais. É uma fonte de pesquisa que propicia acrescentar novas e diferentes interpretações na tradução do mundo, servindo de alternativa a mais para a leitura da realidade, enquanto produto cultural de uma construção feita pelo fotógrafo, sujeito mediador, que seleciona os elementos e enquadra-os na bidimensionalidade de um espaço a ser recortado, permitindo à tecnologia a fixação da cena escolhida. Assim, a construção fotográfica é parte de um contexto histórico e exerce influência na construção do olhar do fotógrafo (FIGUEIREDO, 2014, p. 109-110). 


\section{4 - A LIGHT: ACERVO, TÉCNICAS E REGISTRO}

\section{1 - O acervo fotográfico da Light e seus relatórios}

A pesquisa das imagens fotográficas para este trabalho originou-se com o acesso às fotografias da extinta Light e pertencente ao arquivo digital da Fundação Energia e Saneamento (FES), disponibilizadas no sítio http://www.museudaenergia.org.br/. O acervo da Fundação consiste em materiais produzidos a partir de meados do século XIX e foram, na sua quase totalidade, reunidos em consequência das doações das empresas dos setores de energia quando ocorreram, em boa parte do Brasil, em um contexto capitalista neoliberal da década de 1990, as privatizações de tais setores, além de contar com doações de particulares.

A Fundação surgiu em 1998 e é uma instituição privada sem fins lucrativos, originalmente denominada Fundação Patrimônio Histórico da Energia de São Paulo. Em 2003 o Ministério da Justiça a qualificou como uma Organização da Sociedade Civil de Interesse Público. Em 2004 incorpora a temática do saneamento e é nomeada Fundação Patrimônio Histórico da Energia e Saneamento, ou, simplesmente, Fundação Energia e Saneamento, denominação esta adotada no trabalho.

A FES atualmente tem o seu edifício-sede localizado no bairro dos Campos Elíseos, região central da cidade de São Paulo e que teve o uso social do espaço físico alterado com o passar do tempo. O seu arquivo central localiza-se na cidade de Jundiaí, após longo processo de reabilitação predial nos últimos anos.

Inicialmente a pesquisa ocorreu por meio das reproduções fotográficas disponibilizadas no banco digital de imagens, em virtude do arquivo físico encontrar-se em reforma e adequações, reabrindo somente em meados de 2018. Após as análises e a coleta de dados, contabilizamos 5.807 fotos digitalizadas e distribuídas em 290 páginas no sistema online, com 20 fotos por página e mais 7 fotos na última página verificada.

Ao selecionar as imagens com foco na represa Guarapiranga, conseguimos reunir o total de 120 fotos distribuídas em 6 páginas com 20 fotos em cada página propiciada pelo acervo digital. As imagens nos remetem ao início do século XX, época na qual a represa de Santo Amaro (atual Guarapiranga) estava em construção.

Outras imagens obtidas por meio de cópias fotográficas, além da pesquisada no acervo, também foram utilizadas a fim de comparações, sobretudo nas técnicas 
empregadas para a construção de represas. Nas fotos do acervo que versam sobre a construção da Guarapiranga não constam a referência do autor/fotógrafo em várias fotos, mas a assinatura de B. Klofs faz-se presente em muitas delas, fato que nos permite inferir que o fotógrafo em questão era o principal articulador das imagens produzidas a pedido da Light nas obras da Guarapiranga.

O acervo fotográfico foi composto em sua maior parte pela doação do arquivo do Departamento do Patrimônio Histórico da Eletropaulo ${ }^{38}$, dos acervos da Light e de outras instituições, concentrando a maior parte dos arquivos sobre energia do Estado e cidade de São Paulo, segundo também pesquisado por Silva (2008, p. 23), e permitindo à FES a formação de um centro depositário privilegiado de diversos documentos, inclusive imagéticos, que registram a transformação social e territorial no Estado de São Paulo. A partir do banco de imagens reconstituímos aspectos da paisagem e da história, ressaltando a importância das fotografias na visualização de cenas no processo de alteração paisagística.

As reproduções das fotografias foram utilizadas no trabalho como fontes documentais de registros de uma realidade passada que existiu e foi captada pelo olhar de quem a selecionou e com um propósito definido para aquele momento, que, segundo Burke (2017), são feitas para comunicar e os seus criadores tinham suas próprias preocupações, sem ter em mente, na sua maioria, os futuros pesquisadores. No entanto, as "imagens oferecem evidências sobre a organização e o cenário de acontecimentos [...]" (BURKE, 2017, p. 209).

Segundo Joly (2006, p. 50-55), não existe um método absoluto para análise de imagens, mas não devemos nos esquecer que a imagem é uma mensagem para o outro, assim, equivale considerá-la como uma linguagem de expressão. Porém, a imagem não tem a função metalinguística, que consiste em dizer de seus códigos com seus próprios códigos. Conforme Burke (2017, p. 26), as imagens "são testemunhas mudas, e é difícil traduzir em palavras o seu testemunho". A imagem é composta por elementos que não estão isolados, mas fazem parte de um todo a ser interpretado nas complexas e múltiplas mensagens que podem suscitar no discurso que emitem.

Este consistia em um fato importante para a Light, a fim de promover e divulgar seus feitos para os acionistas, além de ensejar a sua importância para a modernização

\footnotetext{
${ }^{38}$ Em 1981 o governo paulista assume o controle da Light, que passa a ser denominada Eletropaulo Eletricidade de São Paulo S/A. Em 1997 a Eletropaulo é privatizada.
} 
das cidades que estavam ávidas pelo consumo de energia elétrica e maior inserção no mundo moderno, a fim de equiparar-se a grandes cidades da Europa e Estados Unidos.

O conjunto de fotografias da construção da represa Guarapiranga permite a difusão e a elaboração de conhecimentos sobre as modificações do espaço geográfico e configura uma melhor compreensão das técnicas usadas para tal fim, além de constituir fonte de registro histórico da paisagem da região estudada.

As imagens que obtivemos na FES são únicas e referem-se às fontes primárias de pesquisa, embora as tenhamos acessado em uma plataforma digital, melhor visualizadas no equipamento da Fundação, pois permite ampliações e focalizações das cenas com melhor nitidez. Todas as fotografias pesquisadas possuem originalmente a seguinte composição:

Formato: ampliação fotográfica;

Suporte: papel fotográfico;

Cromia: monocromático (preto e branco);

Data: entre 1900 e 1909 (discriminada nas cópias das fotos utilizadas neste trabalho) e seguiam uma ordem cronológica e catalogação arquivística;

Tamanho: variável (discriminado nas cópias das fotos utilizadas neste trabalho);

Origem: álbum fotográfico da Light (atualmente pertencente ao acervo da FES).

As fotos contém ainda um registro ordenador feito pela FES designando, respectivamente, o fundo de origem, o grupo, a série, o álbum e a ordenação sequencial original: [ELE.CEI.SAM.001.1007].

Assim temos:

[ELE.CEI.SAM.001.1007] Fundo (conjunto) Eletropaulo;

[ELE.CEI.SAM.001.1007] Grupo Construções E Instalações;

[ELE.CEI.SAM.001.1007] Série Santo Amaro. Uma única cópia fotográfica utilizada neste trabalho refere-se à Série PAR (Santana de Parnaíba);

[ELE.CEI.SAM.001.1007] Álbum em que se encontra a foto. Observamos que todas as fotos da Guarapiranga utilizadas no trabalho são do Álbum 001, embora algumas não possuam a numeração que o designa, conforme apuramos, a não contiguidade dos procedimentos de registro no momento das catalogações;

[ELE.CEI.SAM.001.1007] Numeração de ordem sequencial a partir dos registros originais da Light e seguindo a ordem cronológica das datas das fotos. 
Notamos, também, que todas as legendas existentes estão inseridas no corpo da fotografia. Esta característica pode evidenciar uma lógica de catalogação e controle do registro das realizações da Light no espaço geográfico.

Percebe-se também que a legenda existente na foto do original digital não estava presente na imagem física que compunha o relatório físico da Light, apesar de se tratar de mesma imagem. Tal fato leva-nos a presumir que a ordem cronológica da catalogação da empresa era posterior ao relatório.

Segundo Carvalho (2003, p. 55), em sua pesquisa sobre as impressões da modernidade em São Paulo no final do século XIX e início do XX, e por nós também verificado,

há uma significativa quantidade de registros referentes ao período das primeiras obras de instalação da infraestrutura, entre 1900 e 1903 [em Santana de Parnaíba]; posteriormente, eles são produzidos com menor regularidade.

As atividades da Light em São Paulo eram registradas para informações a sua matriz em Toronto (Canadá) e sua prestação de contas era embasada em dados concretos, muitos deles realizados por meio de fotografias juntamente com registros textuais. Segundo Carvalho (2003, p. 34):

As imagens fotográficas tinham o propósito de comprovar as obras da empresa perante seus representantes no exterior, para uso da empresa no Brasil, e também como demonstração de suas atividades perante o governo da cidade e do Estado de São Paulo. Para a matriz canadense tal documentação possibilitava igualmente avaliar à distância como se comportavam componentes e artefatos técnicos, projetados inicialmente para operar em climas temperados [de médias latitudes], quando aplicados ao nosso clima tropical.

De fato, a empresa produzia relatórios anuais que continham suas atividades desenvolvidas de maneira sistematizada em uma organização composta por textos redigidos, gráficos, tabelas, mapas e imagens fotográficas. O redator anuncia tais preocupações no relatório da Light, de 1902:

Desejamos que nossos Acionistas estejam completamente informados da natureza do empreendimento que executaram, das condições satisfatórias que prevalecem na comunidade em que seu dinheiro é investido e do negócio valioso, tanto no 
presente quanto no futuro, que é controlado pela Companhia (Relatório apud CARVALHO, 2003, p. 34).

As imagens fotográficas feitas pelos fotógrafos registram muitas das transformações urbanísticas que marcaram o final do século XIX e início do XX, em um espaço urbano de rápidas alterações físicas e estruturais. Essas imagens foram produzidas sob a perspectiva das transformações modernizadoras a fim de atender as diversas finalidades a que se propunham (CORREA, 2005, p. 57). No entanto, somos advertidos por Carvalho (2003, p. 36) a não ler nas imagens aquilo que já foi difundido pela 'circularidade da interpretação'.

Cavenaghi (2000, p. 49), em sua pesquisa sobre as imagens fotográficas da cidade de São Paulo no acervo da Light, observou que a coleção de fotografias da empresa

atendeu a uma lógica muito mais arquivística do que de circulação pois tinham a função de capturar, em sua grande maioria, as intervenções da Companhia em solo paulistano e estas representações do trabalho, dos objetos e das necessidades da Empresa passaram a ser ícones representativos de sua produção imagética.

O caso das confecções dos trabalhos imagéticos produzidos pela Light, segundo Cavenaghi (2000, p. 332) e a nosso ver, atendia a um raciocínio de catalogação imposta ao seu acervo que pretendia inserir a companhia, por meio de suas realizações tecnológicas, no contexto modernizador do período.

Podemos observar em nossa pesquisa os relatórios que a companhia realizava no decorrer dos anos em que estivera em São Paulo e que fazem parte do acervo da FES, cujo relatório mais antigo do arquivo é datado de 1902, indo até 1971.

Nos anos em que a Guarapiranga estava sendo construída, os relatórios das atividades da Light coligiam uma série de estatísticas sobre seus empreendimentos e sobre a cidade de São Paulo: o número populacional da cidade, demonstrações financeiras, número das estações de luz, linhas de transmissão de luz, telefone, lâmpadas utilizadas, acidentes relacionados com as linhas de bonde e de transmissão de energia, estimativas de custo, taxas de luz, depreciações e leis de interesse para a companhia. Todos esses registros salientavam os trabalhos na Capital e as atividades iniciais em Parnaíba e pouco há efetivamente sobre os registros em Santo Amaro e a sua represa, embora não tenham sido negligenciados. 
Os relatórios anuais eram feitos em papéis de baixa gramatura, semelhante ao papel de seda, e datilografados em língua inglesa e com índice em suas páginas iniciais. Esse conjunto de folhas era encadernado em capa dura contendo o seguinte título impresso em letras douradas: The São Paulo Tramway, Light \& Power Co. Ltd. Annual Report, e o ano que se referia, conforme observado na imagem (Figura 17) ${ }^{39}$.

Figura 17: Frontispício dos relatórios encadernados da Light para os anos de 1906, 1907 e 1908

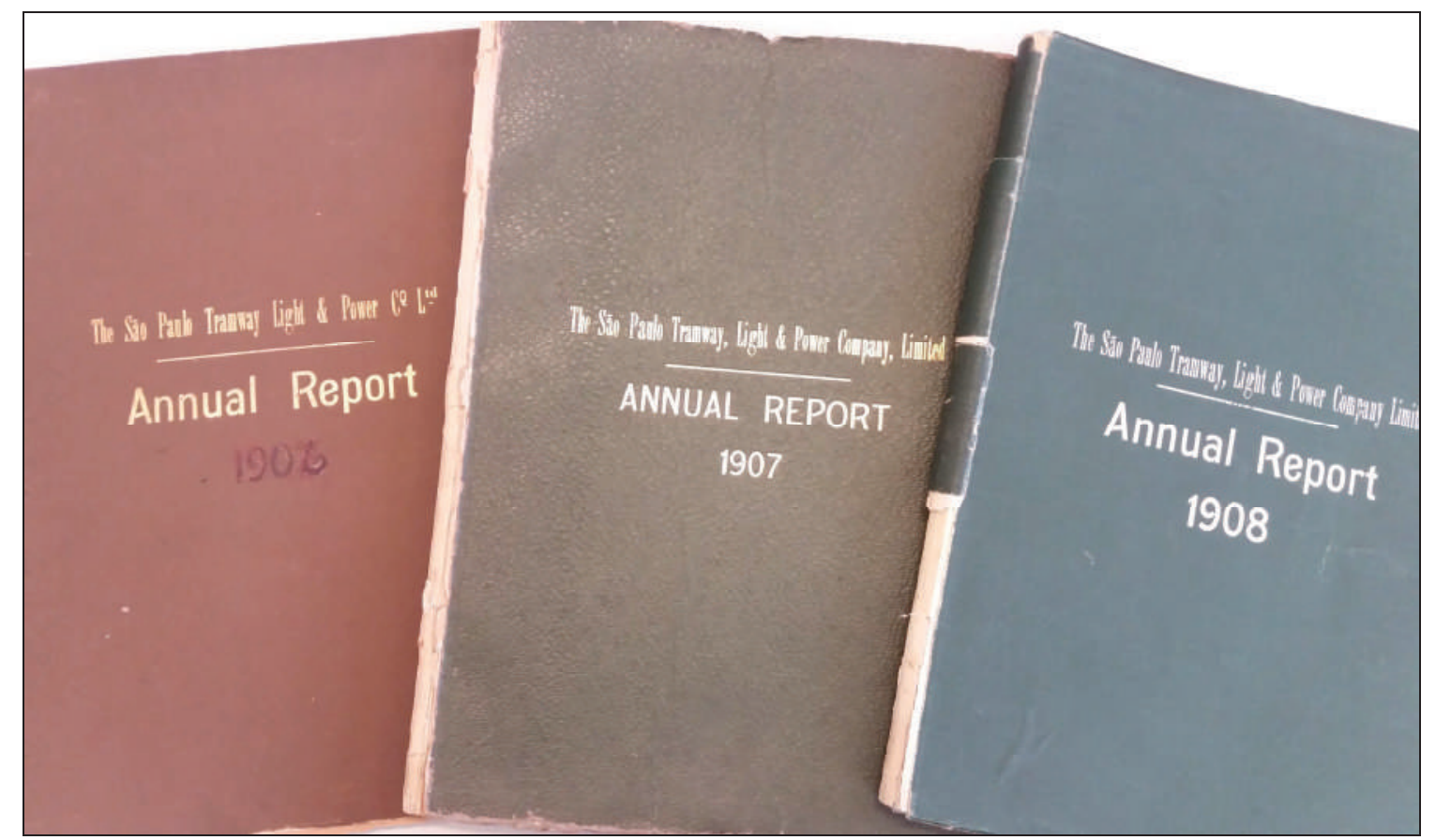

Fonte: Arquivo da FES. Registro fotográfico do autor (2018).

${ }^{39} \mathrm{O}$ seu tamanho físico é de $27,9 \times 20,2 \mathrm{~cm}$ e possui o quantitativo de páginas de acordo com o ano de referência: ano de 1906 - 48 páginas, sem imagem alguma juntada ao relatório; 1907 - 60 páginas, com gráficos, mapas e cópias de fotos no seu interior; 1908 - 106 páginas, com cópias de fotos, tabelas estatísticas de custos e mapas; 1909 - 59 páginas, com gráficos contábeis, estatísticas de valores de custos. Quase todo o conteúdo refere-se à construção de Parnaíba e às diversas instalações da Light na Capital. 
As tabelas e imagens (cópias fotográficas, mapas e gráficos) que compõem os relatórios anuais são em blueprint, suportes em papel semelhante ao papel vegetal, de fundo azul e linhas brancas, ou vice-versa, para representações técnicas de projetos de engenharia ou arquitetura, muito utilizados pela Light e anexados em seus relatórios.

Observamos na composição das imagens a seguir (Figura 18) um blueprint de uma fotografia originalmente produzida pela Light, a mesma imagem também foi reproduzida em papel monocromático e está disponibilizada no acervo digital, ora reproduzida. Mais adiante pormenorizamos as imagens. 
Figura 18 - Cópia de blueprint e cópia fotográfica da construção da nova grade de proteção na entrada do cano de descarga da represa de Santo Amaro (Guarapiranga), respectivamente, 1909

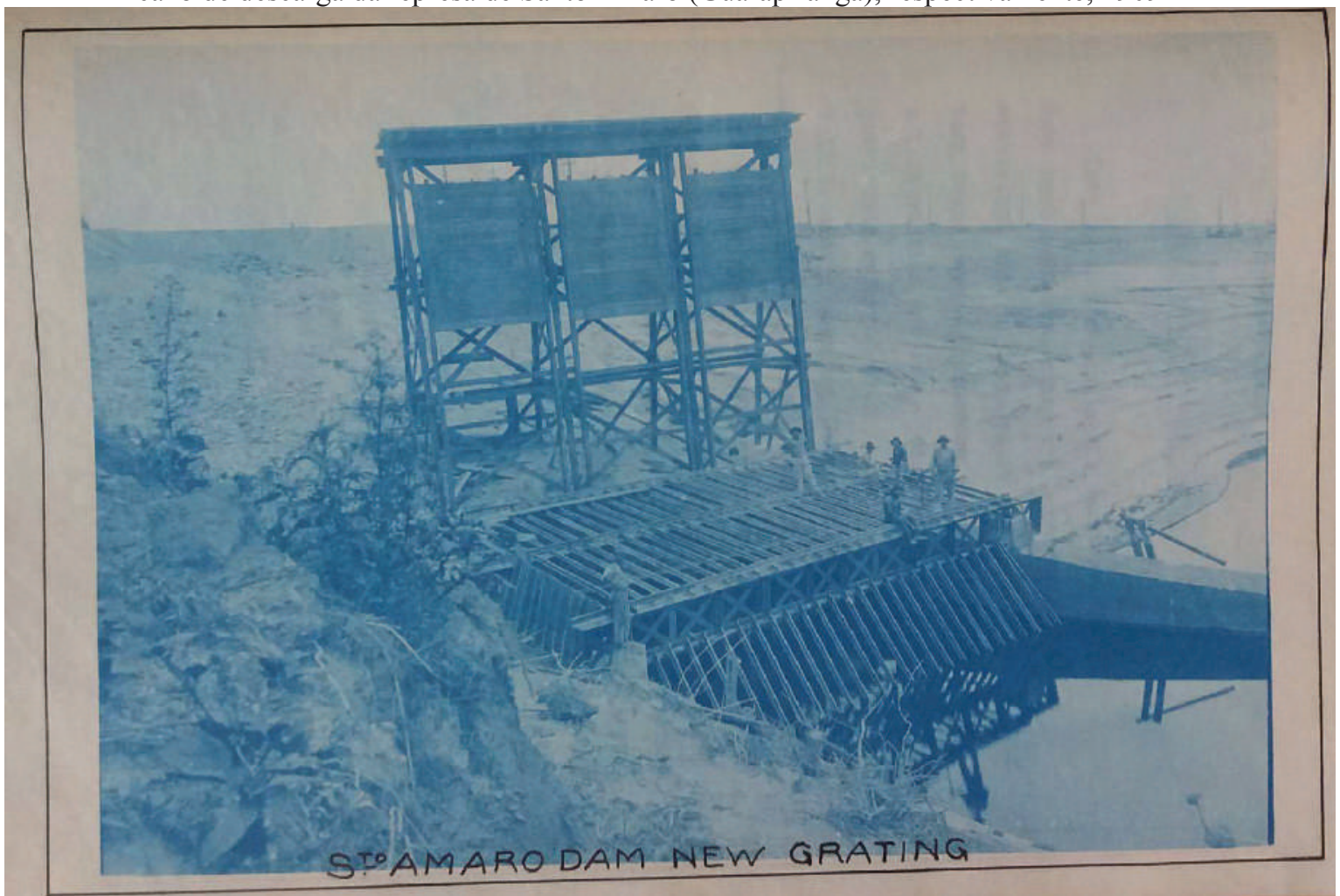

Fonte: Relatório anual da Light: Annual Report, 1909, entre as páginas 96 e 97. Acervo da FES. Registro fotográfico do autor (2018).

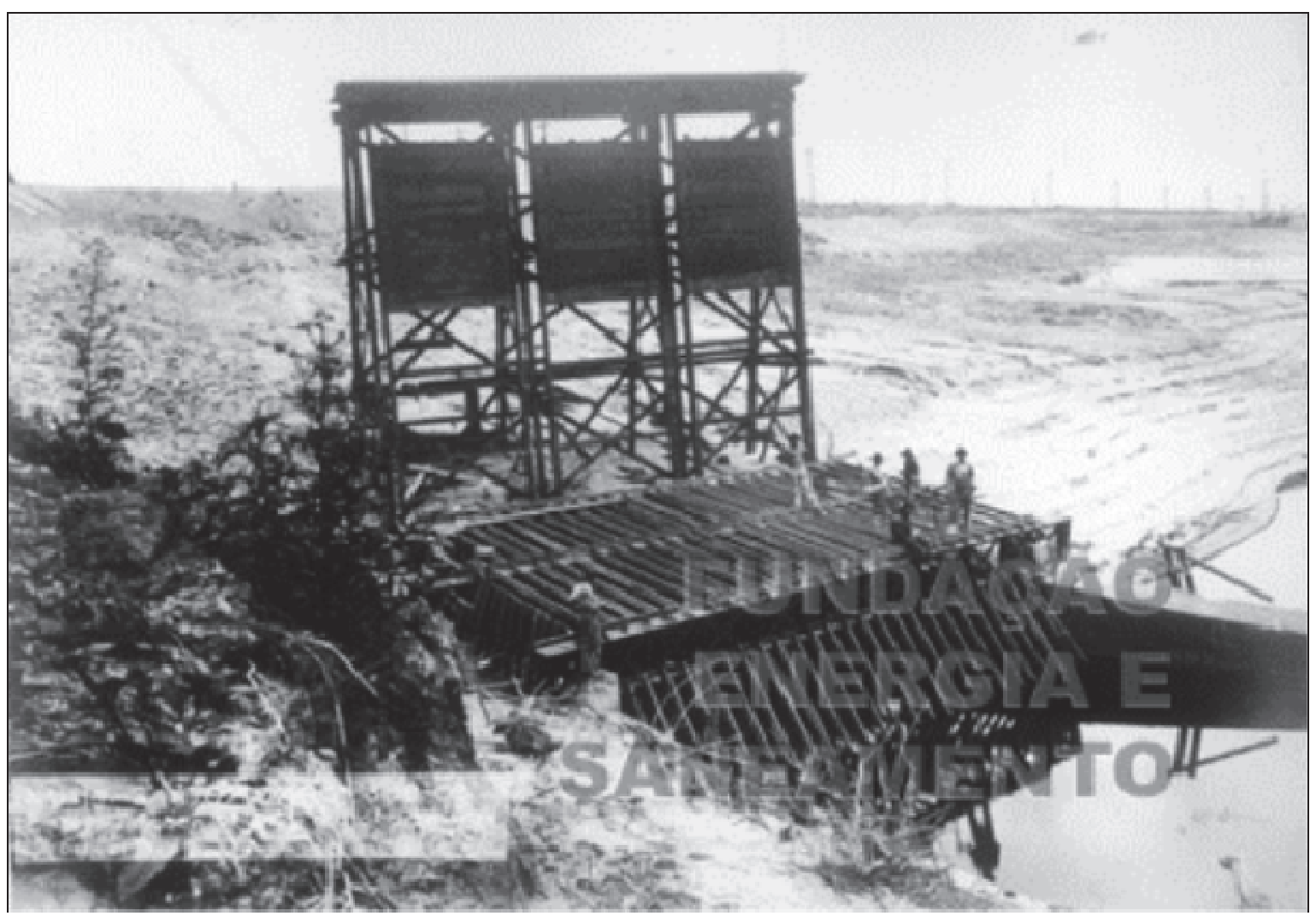

Fonte: Acervo digital da FES (2018). Original: 16,5 x 22,5 cm [ELE.CEI.SAM.001.1114] 
Trata-se da construção de uma grade de proteção para o cano de descarga da represa Guarapiranga, datada de 1909, com a seguinte legenda na base esquerda da cópia fotográfica disponibilizada no acervo digital: $N^{\circ}$ 1114. Santo Amaro - 30.1.09 New screen of entry end of dischappe culveris. Essa mesma imagem estava inserida no relatório da Light de 1909, mas sem a legenda, indicando que a mesma era inserida após o registro da imagem pelo fotógrafo, juntamente com a catalogação pela empresa.

Na representação o fotógrafo centralizou o equipamento técnico, importante para a formação da represa e as seis pessoas em cima da grade de proteção do cano de descarga d'água nos dão a ideia de escala.

Em outra comparação entre as fotografias produzidas e aqui inseridas (Figura 19), notamos que o agrupamento humano em uma foto está registrado de modo organizado em fileira de pessoas e com um suposto líder presente a organizar e submeter as posturas dos demais homens, como se posassem para o fotógrafo. Diferentemente ocorre com a segunda fotografia, dando a impressão que o trabalho não fora interrompido para o fotógrafo registrar a cena. Os homens aparecem de maneira mais espontânea. 
Figura 19 - Cópia fotográfica. Composição de imagens da construção da represa Guarapiranga, 1906 e1909, respectivamente

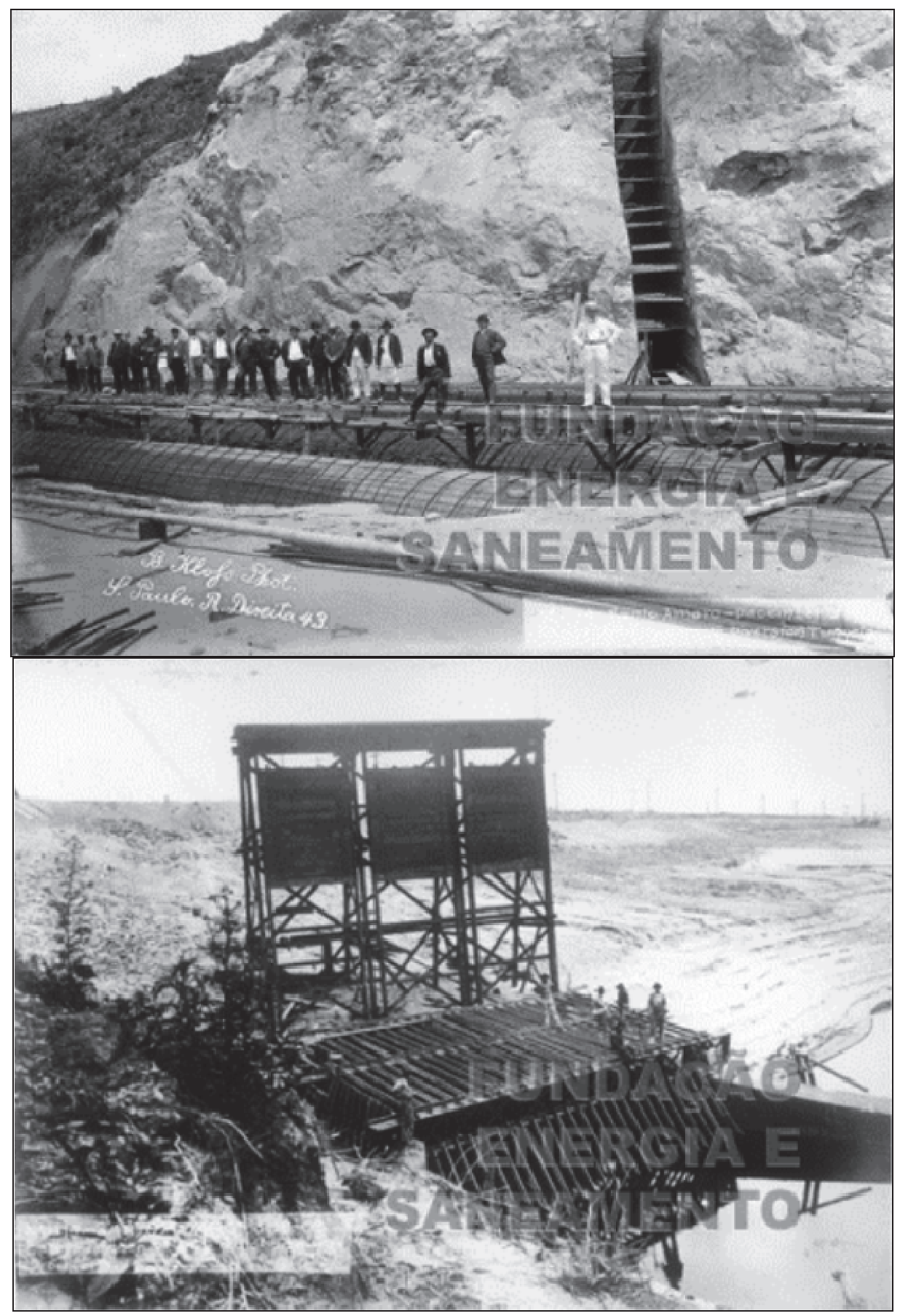

Fonte: Acervo digital da FES (2015 e 2018). 
O interesse da companhia estava no registro das obras, fato este que fez com que o fotógrafo ao longo da produção imagética seriada, centralizasse e dimensionasse a sua visão para os equipamentos produzidos e na paisagem que ia se transformando com o avanço da construção.

Em outro blueprint anexado ao relatório anual de 1908 (Figura 20), está o mapa feito pela Light para os estudos de rotas de linhas de energia elétrica de São Paulo para Santo Amaro. Nele encontram-se representadas as manchas urbanas das referidas cidades e outras localidades, além das linhas de estrada de ferro, da rede hidrográfica da região e a da represa de Santo Amaro com o represamento do rio Guarapiranga e seus afluentes (representado no mapa pelo fino hachurado em vermelho). Ao norte da mancha urbana de São Paulo tem-se, também, a representação de parte do principal rio de drenagem do espaço representado: o rio Tietê.

Pela escala de representação notamos a dimensão do represamento das águas em relação ao sítio urbano de Santo Amaro e da Capital, correspondendo a uma grande extensão do terreno transformado pela Light, muito maior fisicamente que a urbe de Santo Amaro, que foi radicalmente transformada pela proximidade da represa. 
Figura 20 - Cópia de blueprint do reservatório de armazenamento de águas. Represa de Santo Amaro (atual represa de Guarapiranga), 1908. Escala: 1:200.000

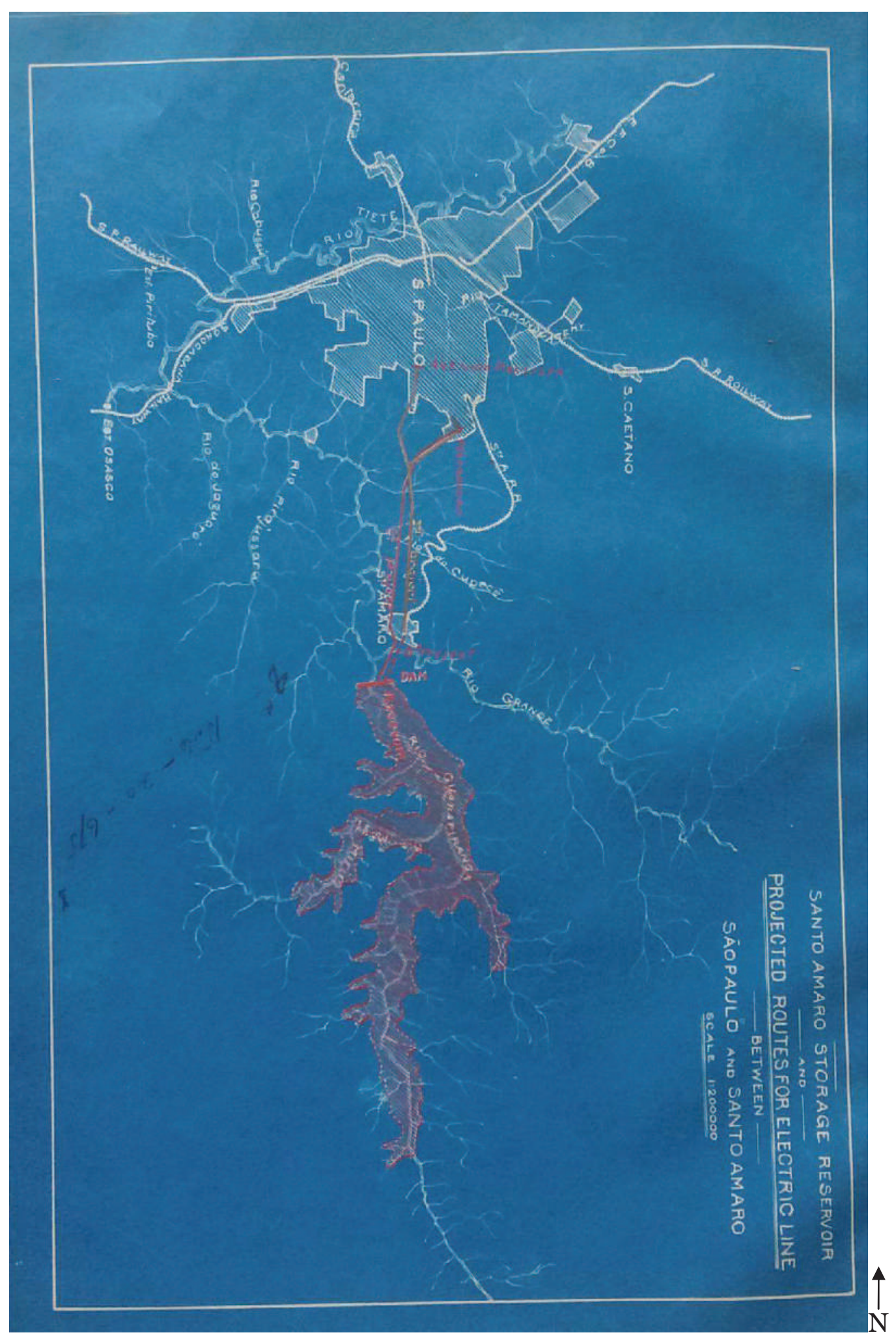

Fonte: Relatório anual da Light: Annual Report, 1908, documento anexo. Acervo da FES. Registro fotográfico do autor (2018). 
Os relatórios anuais feitos pela Light eram todos endereçados para o The President and Board of Directors of The São Paulo Tramway, Light and Power Co. Ltd. (Presidente e Conselho de Administração) e assinado respectifully submitted (de maneira respeitosa e submetida) pelo General Manager (Diretor Geral) da companhia em São Paulo: W.N. Walmsley.

As imagens encontradas nos relatórios referentes aos anos de construção da represa (1906 a 1909), incluindo as dos anos de 1910, 1911, 1912 e 1913, foram encartadas ao longo dos escritos e não eram paginadas, ou seja, eram feitas em separado e serviam como complementação do texto redigido. Estas imagens, sejam gráficos, tabelas, mapas ou cópias de fotografias, eram todas, com as raras exceções de algumas tabelas, feitas em blueprint, como os demonstrados em duas imagens anteriores.

As fotos eram produzidas para cumprir um propósito definido, sendo as imagens "[...] testemunhas dos arranjos sociais passados e acima de tudo das maneiras de ver e pensar do passado" (BURKE, 2017, p. 278).

\section{2 - Análise do corpus: 0 rio, o homem, a técnica e a represa}

A imagem é de fato uma linguagem específica e heterogênea e nessa qualidade distingue-se do mundo real por meio de signos particulares e propõe uma representação escolhida e necessariamente orientada, cuja interpretação permite, ao mesmo tempo, a compreensão dos seus fundamentos e garante a liberdade de pensamento em sua análise dentro de uma de suas funções que é a pedagógica (JOLY, 2006, p. 48).

As imagens fotográficas, segundo Joly (2006, p. 119), proporcionam a construção de narrativas em suas relações causais e temporais. Assim, a partir do acervo imagético da construção da represa Guarapiranga, que alterou significativamente o espaço geográfico da cidade de São Paulo e seu entorno, foi possível construir uma narrativa da transformação sofrida pelo meio em virtude da implementação de novas técnicas construtivas e da apropriação e configuração espacial, no qual as imagens contém um sentido, exigindo mais esforço a fim de compreendê-las melhor se estiverem afastadas do nosso tempo e espaço (AUMONT, 2006, p. 250). Para Joly (2006, p. 128) 
uma fotografia é construída por meio de escolhas, constituindo-se assim a sua significação de maneira convencional e cultural.

Em nosso trabalho abarcamos o período de construção da represa Guarapiranga (1906-1909), no qual, tanto Santo Amaro como a cidade de São Paulo passaram por transformações marcadas pelas suas reestruturações urbanas, período do governo de Antônio Prado (1889 - 1911) à frente da prefeitura de São Paulo. Os novos elementos construídos tornaram-se referências para uma nova cidade pretendida, como a sua expansão espacial, o desenho urbanístico e a utilização de tecnologias, cuja divulgação foi parte fundamental para a implantação de uma inusitada maneira de estar e viver a cidade.

As imagens fotográficas produzidas foram importantes no sentido de formar um conjunto visual das cidades e conforme Cavenaghi (2000, p. 7) em sua pesquisa,

a informação fotográfica, fruto da sociedade industrial burguesa, adquire caráter científico através de seus procedimentos físico-químicos, corroborado por meio da apropriação visual de novos elementos tecnológicos incorporados ao cotidiano da cidade (postes de luz, lâmpadas de arco voltaico etc).

Para atingir o nosso objetivo da análise da paisagem por meio das fotografias tivemos na sequência das imagens uma percepção das diferenças impostas ao local, permitindo visualizar as transformações operadas pela ação do homem no território e a percepção destas diferenças a fim de se trazer sentido às representações.

$\mathrm{Na}$ análise de corpus, temos o rio, a ação humana por meio das técnicas e a formação da represa, cuja análise iniciamos com uma abordagem das questões físicas do território, a partir da natureza e de seus elementos, tornando possível a atuação concreta no espaço a ser configurado.

Ao tratar da região da cidade de São Paulo pode-se dizer que está inserida no clima tropical, com características locais modificadas pela altitude que se devem principalmente a topografia do Alto Tietê e a sua relativa proximidade do oceano. Quanto à umidade do ar, apresenta valores normalmente elevados, destacando os meses de verão como os mais úmidos (FRANÇA, 1958, p. 69 e 87), fato que interferirá no regime hidrográfico da região. 
Ao sul da cidade, onde a represa Guarapiranga foi construída, encontra-se a faixa mais úmida do Planalto Atlântico, devido principalmente a sua localização no contraforte da Serra do Mar e à forte condensação registrada nas escarpas da serra. Tal umidade seria futuramente agravada pela extensa superfície líquida das represas da Light, Guarapiranga e Billings, conforme observação de França (1958).

Quanto à vegetação, havia extensas áreas cobertas com formações florestais nas escarpas do Planalto; nas várzeas do rio Tietê, do Pinheiros e outros afluentes havia formações arbustivas próprias de terrenos inundáveis. Segundo constatou França (1958), o elemento característico do que ainda restou da formação original sobressai a presença de formações herbáceas a recobrir as colinas da região, com manchas escassas de capoeiras. Eram "pequenos capões de mato, pouco elevados, em alguns pontos contíguos, e disseminados em meio de tabuleiros de relva muito rente ao solo", conforme a descrição de Saint-Hilaire (apud FRANÇA, 1958) que os viu há mais de um século. Estes constituíam os afamados campos de São Paulo, “[...] que os primeiros habitantes da região designaram, com os indígenas, de Piratininga [...]”, uma espécie de clareira no meio das matas circunjacentes, observação daqueles desde o século XVI, ao transpor as florestas da Serra do Mar rumo ao Planalto (FRANÇA, 1958, p. 101).

Esses campos paulistanos teriam sido alterados e constituíam em uma fase da sucessão ecológica ${ }^{40}$, levando-se em consideração o ambiente de uma bacia de sedimentação de solos reconhecidamente pobres dentro da depressão do Planalto Atlântico, de rochas cristalinas. Porém, segundo França (1958), muitos outros especialistas afirmam que toda a região de São Paulo, e provavelmente todo o Estado, era recoberto por matas de porte exuberante. França (1958, p. 105) também afirma que o índio foi um incansável "devastador de florestas" e que, provavelmente, a região de matas menos densas resultou de queimadas feitas em épocas pré-cabralinas, ou seja, a vegetação já tinha sido alterada há tempos pela ação humana. Notamos, com isso, que o homem sempre alterou o espaço com intuito de melhor adequá-lo aos seus desejos e a transformação ocorre com maior ou menor intensidade de acordo com as técnicas empregadas, ressaltando em nosso trabalho a atuação humana no modo de produção capitalista, diferentemente da ação indígena nos tempos pretéritos à formação da cidade.

\footnotetext{
${ }^{40}$ A sucessão ecológica é definida como alterações graduais, ordenadas e progressivas no ecossistema resultante da ação contínua dos fatores ambientais sobre os organismos, até que eles atinjam a estabilidade ou clímax (Página virtual do INSTITUTO DE BIOCIÊNCIAS - USP. Acesso em: 20 jul. 2018).
} 
Para o botânico Kurt Hueck (1897-1965) a vegetação primária da região era constituída por floresta subtropical de planalto, embora ela já não existisse mais desde aproximadamente a metade do século XIX. Assim, na maior parte do Planalto Paulistano havia formações arbustivas e herbáceas, constituindo campos, várzeas inundáveis com restos esporádicos que surgem de mata e capoeiras, pouco restando da vegetação original na região da cidade no período da construção da represa (FRANÇA, 1958, p. 105).

No mapa a seguir (Figura 21) vemos a distribuição dessa vegetação original na cidade de São Paulo e região, já com as delimitações das represas Guarapiranga e Billings a configurar na representação cartográfica. Trata-se de um estudo de Hueck acerca das formações vegetais, possibilitando-nos uma visão a mais dos elementos naturais que compunham o território em período anterior à formação dos reservatórios d'água.

Ao redor da Guarapiranga notamos a presença da floresta subtropical do planalto e floresta de inundação, como já observado anteriormente. 
Figura 21 - Mapa da vegetação original da cidade de São Paulo e vizinhanças, conforme classificação de Kurt Hueck. Destaque para a represa Guarapiranga

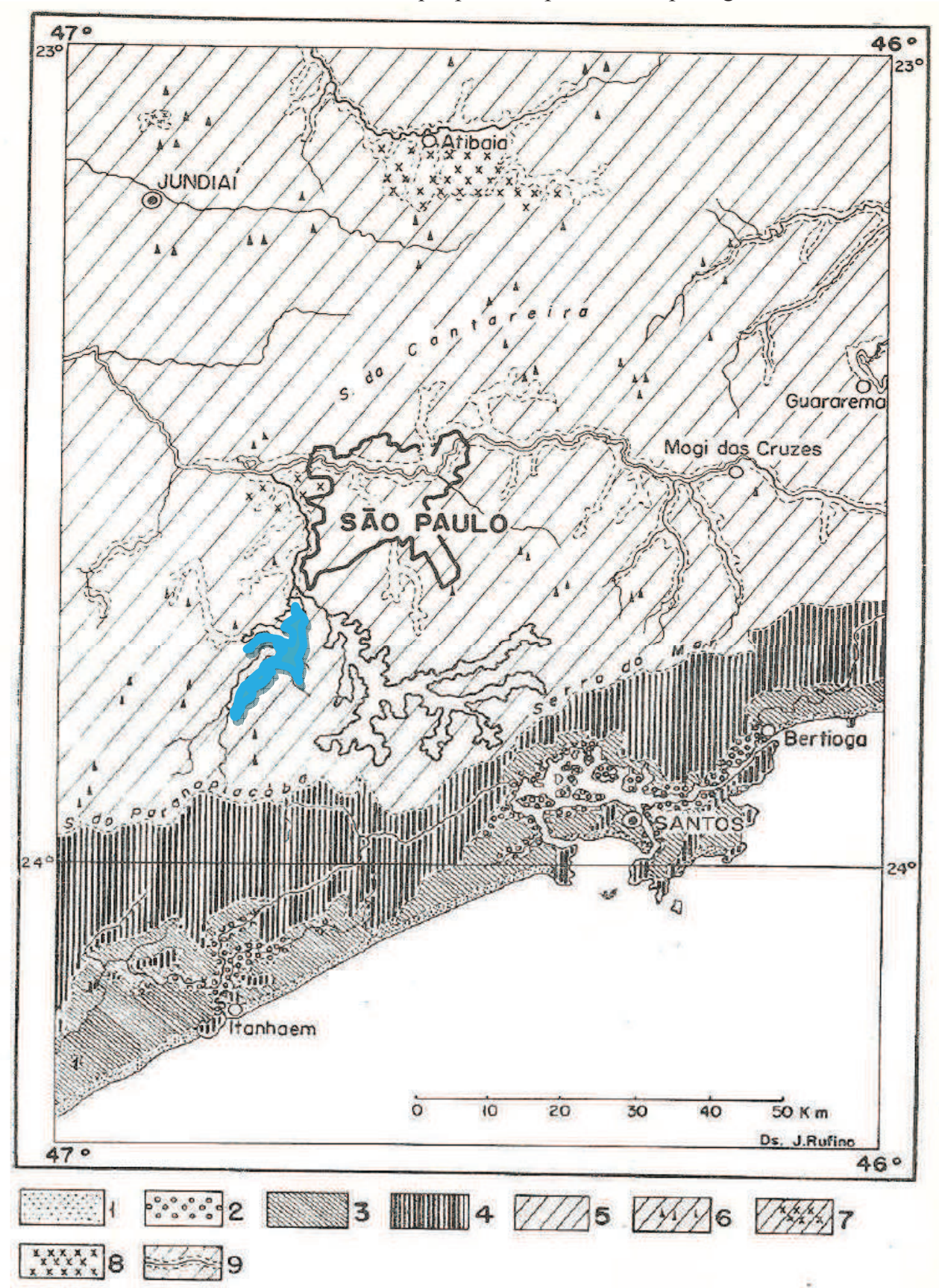

\footnotetext{
1. Restinga

2. Mangue

3. Floresta tropical da planície litorânea

4. Floresta tropical da Serra do Mar

5. Floresta subtropical do Planalto

6. Floresta subtropical do Planalto, com araucárias disseminadas

7. Floresta subtropical do Planalto, com elementos do cerrado

8. Campos cerrados

9. Floresta inundável
} 
O rio Guarapiranga e seus afluentes fazem parte da bacia hidrográfica do rio Pinheiros, situado à margem esquerda do Tietê, o principal rio da cidade e região e sempre foi muito utilizado como via de locomoção e transporte tendo o seu contorno profundamente alterado em vários de seus trechos, acompanhando o crescimento da cidade.

Na cópia fotográfica (Figura 22), de autoria não identificada (supostamente de B. Klofs), vemos a legenda original da Light: $N^{\circ} 1003$ - Santo Amaro - March, 1906. Guarapiranga Bridge. Esta foi produzida tendo o rio Guarapiranga como ponto de referência e registrada pelo fotógrafo em uma tomada a centralizar o rio e a ponte ao fundo, preenchendo praticamente toda a foto, juntamente com o céu a auxiliar na visualização do rio e a dimensionar a vegetação, na composição monocromática. Em suas margens a vegetação ciliar compõe a várzea e foi representada cartograficamente como Floresta Inundável, no mapa anterior. A ponte, conforme pesquisado, servia como meio facilitador no deslocamento das pessoas.

Figura 22 - Cópia fotográfica. Ponte Guarapiranga, 1906

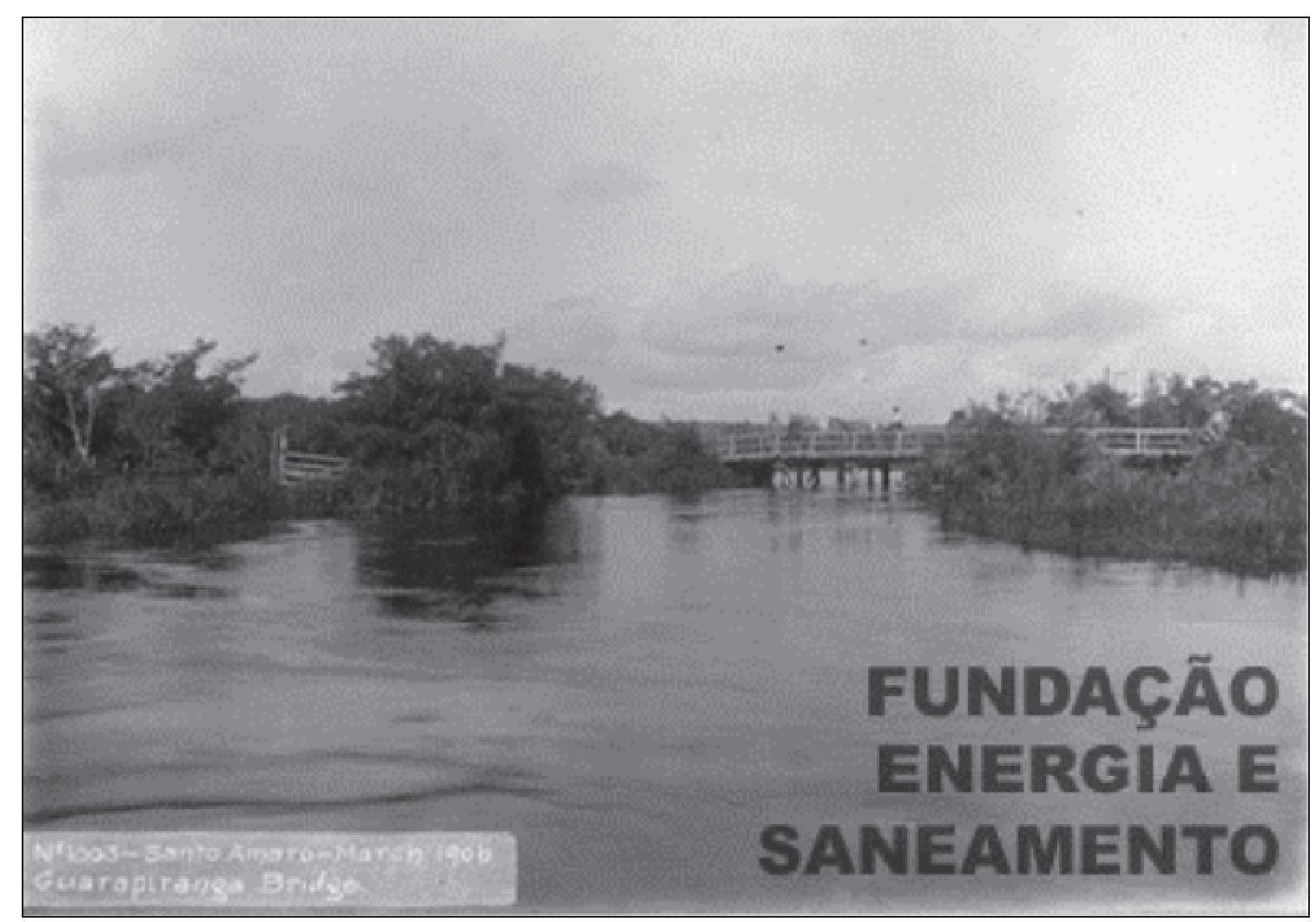

Fonte: Acervo digital da FES (2015). 17,5 x 22,5cm [ELE.CEI.SAM.1003] 
Segundo Ab’Sáber (1958, p. 209-210), são compreendidos pelo termo 'várzeas', “todos os terrenos de aluviões recentes, desde os brejais das planícies sujeitas à submersão anual, até às planícies mais enxutas e menos sujeitas às inundações, existentes nas porções mais elevadas do fundo achatado dos vales" e são constituídas por planícies alongadas interpenetrando pelo Tietê e Pinheiros e pelos baixos vales de seus afluente principais, como o Guarapiranga.

Ab’Sáber (1958) também observou em todas as várzeas paulistanas a constância de uma cobertura superficial de solo turfoso espesso escuro, recobrindo grandes áreas, enquanto a cidade de São Paulo permanecia nas colinas e por elas se expandia nas diversas direções. As várzeas foram,

[...] uma espécie de quintal geral dos bairros. Serviam de pastos para os animais das antigas carroças que povoavam as ruas da cidade $[\ldots]$

Em seus terrenos mais firmes, as várzeas asilaram grandes chácaras, de aparência pobre, e humildes moradias de trabalhadores que viviam do rio ou da própria terra varzeana. Proliferaram, desta forma, por toda sua extensão, as olarias que ajudaram a construir a cidade. 'Portos' de areia e cascalho pontilharam o dorso dos diques marginais dos rios, contribuindo com a porcentagem mais importante dos materiais de construção [...] (AB'SÁBER, 1958, p. 216-217, itálico do autor).

O desenvolvimento urbano sempre esteve atrelado às águas dos rios que impunham estratégias a serem adotadas no desenvolvimento da cidade que nasceram e se desenvolveram por três séculos à sombra do transporte animal, pertencendo inteiramente ao chamado ciclo do muar que atingiam os topos íngremes das colinas pelas ladeiras abruptas. Segundo Ab'Sáber (1958, p. 221),

os bairros e embriões de bairros que se formaram além-Tiete e além-Pinheiros sempre permaneceram isolados do corpo principal da cidade, não pela existência dos rios, mas principalmente pela presença das largas várzeas submersíveis e malsãs.

Poucas referências são encontradas sobre essas áreas de várzeas na região do rio Guarapiranga e o período da construção da represa, com exceção dos estudos de Jorge (2015). Embora haja pouco material redigido sobre a construção da Guarapiranga, 
temos nas fotografias registradas uma representação dessas áreas, constituindo um suporte documental que nos permite discorrer sobre a história e o processo de transformação da paisagem.

A análise do acervo fotográfico produzido pela Light entre 1899 e 1911, feita por Cavenaghi (2000) em sua pesquisa, observa que a maioria das imagens mostra a intervenção da companhia na estrutura urbana de São Paulo, redesenhando o seu espaço juntamente com as modificações tecnológicas implementadas, porém esta análise se circunscreve na região central da cidade, não trazendo referências à construção da Guarapiranga, no entanto relata a preocupação da Light em atuar não só no tecido central da cidade.

As imagens seguintes narram o processo de ocupação do solo para a construção da represa e tem articulação direta com o espaço urbano e as novas ideias desenvolvimentistas para a produção energética.

O fotógrafo não formulou uma obra ao acaso. Podemos comprovar tal fato pela análise dos seus aspectos visuais, observando o objeto fotografado, o seu ângulo de exposição, o seu enquadramento, como as mesmas foram produzidas e a inserção deste objeto no contexto de São Paulo/Santo Amaro e, ainda, a articulação do tema fotografado com o momento histórico representado.

Primeiramente (Figura 23) observamos no terreno a vegetação predominantemente secundária, formada por campos de altitude e por várzeas ao longo dos vários rios existentes na região, segundo a definição de Whately e Cunha (2006, p. 30). Primitivamente a área era ocupada pela floresta subtropical de planalto com araucárias esparsas, na identificação de Hueck (FRANÇA, 1958, p. 102).

Notamos nesta imagem que o fotógrafo preocupou-se em registrar o terreno antes do início das obras da represa, focando na vegetação existente como o elemento marcante a compor a área. Ao fundo da cópia fotográfica reparamos a presença de uma casa com telhado de duas águas, provavelmente de algum sitiante local. Nessa época a ocupação da região, embora existisse desde períodos pré-coloniais, era baixa. Em um relato de um médico milanês em seu diário de viagem, quando de passagem pela região e a bordo do recém inaugurado trem a vapor (1886) que ligava São Paulo (Vila Mariana) a Santo Amaro, comenta: "De Vila Mariana prolongava-se a estradazinha de Santo Amaro, por vinte quilômetros através de planície árida e despida, onde só quase havia vegetação rasteira, desértica, por assim dizer" (BERARDI, 1981, p. 84). 
Até meados do século XIX os engenheiros ferroviários procuravam assentar os trilhos sobre os terrenos mais enxutos, pertencentes aos terraços fluviais, evitando os terrenos aluviais alagadiços e inconsistentes do Tamanduateí. O fato que auxiliou a penetração urbana nas terras além-Tamanduateí foi o traçado da São Paulo Railway e o ponto de entroncamento com a Central do Brasil (antiga Estrada de Ferro São Paulo Rio de Janeiro) no Brás (AB’SÁBER, 1958, p. 241).

Na legenda original da Light, localizada na base inferior à esquerda da foto lêse: $N^{o} 1009$ - Santo Amaro - April 1906. Dam Site East of Road (vista do terreno da represa a partir do leste da estrada onde se encontrava o fotógrafo).

Figura 23 - Cópia fotográfica. Construção da represa de Santo Amaro (atual Guarapiranga). Local da barragem a leste da estrada, 1906

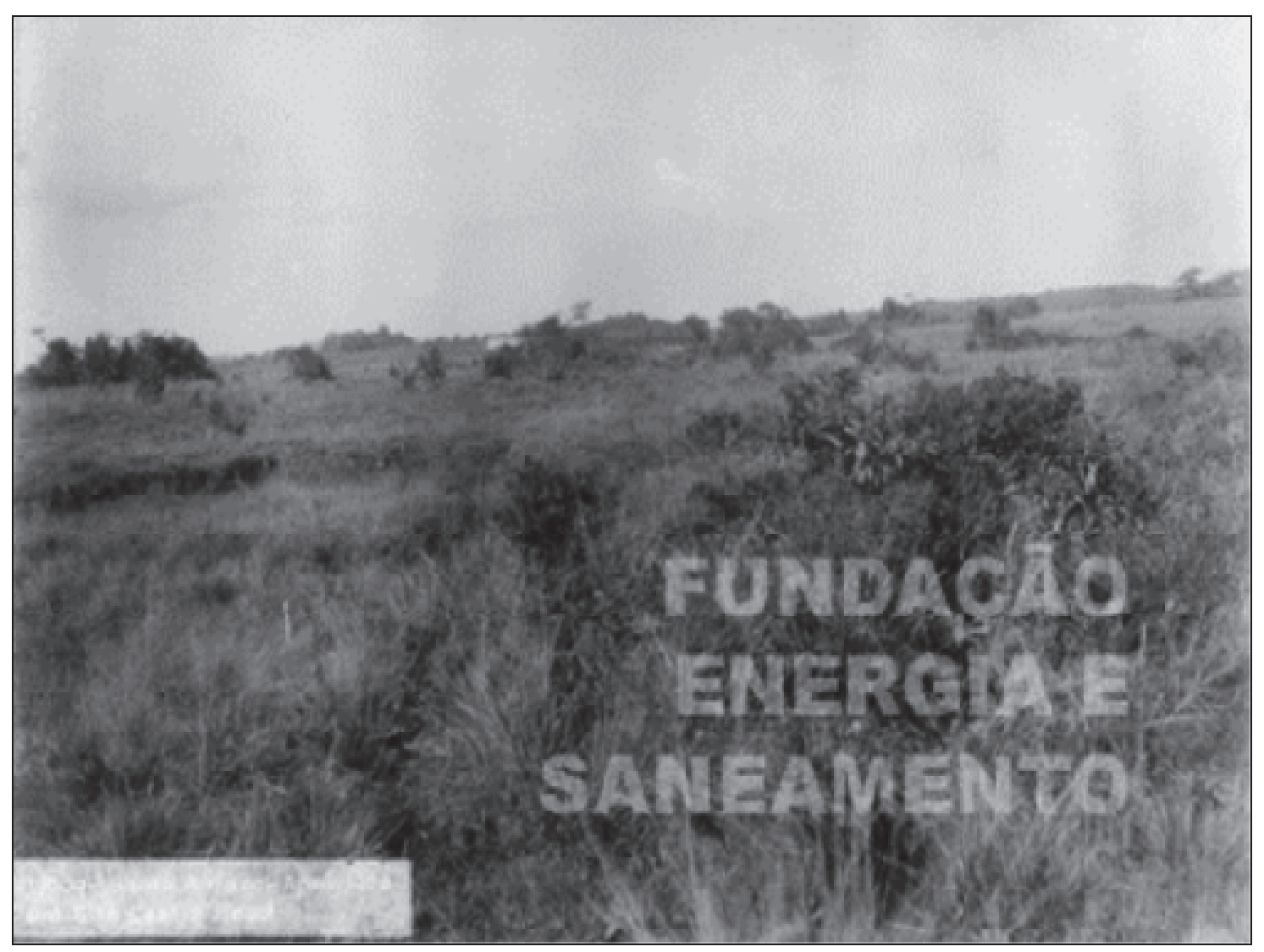

Fonte: Acervo digital da FES (2015). 17,0 x 23,0 cm [ELE.CEI.SAM.001.1009] 
Como parte do início da construção da represa, o terreno teria que ser preparado, retirando-se a vegetação de maior porte composta já em grande parte por matas secundárias. O trabalho de 'limpeza' contou com a força de muitos homens e animais para tração e locomoção, tanto de pessoas como de materiais, fato que foi registrado em fotografia pela Light, como na imagem (Figura 24), com a legenda original escrita: $N^{o}$ 1022 - Santo Amaro - August 1906. Dam Site East From River After Stripping Completed, que tem em seu centro um homem retratado em posição de destaque pelo fotógrafo. Ele está de pé em cima de troncos de árvores derrubadas a observar o terreno já desprovido da alta vegetação e posando para o fotógrafo que se distanciou do objeto a fim de registrar, o máximo possível, a ação humana na área, como sendo esta a protagonista da imagem.

A Light usa a visualidade para demonstrar sua ação de poder. Pela disposição dada à cena, uma relação de posse, intensificada pela presença da figura representativa de um homem de paletó e gravata ao centro da imagem, servindo como elemento comparativo das proporções da área a ser convertida em represa.

Outros grupos de homens são enquadrados na fotografia, sem destaque, mas presentes na figuração da cena, de forma aleatória ou proposital, não sabemos. Eles trabalham em carregar troncos de árvores. Podemos associar a imagem à ideia do domínio do homem sobre a natureza, por meio do desenvolvimento das técnicas, às quais, sintetizadas pela Comissão Geográfica e Geológica de São Paulo (1886 - 1931), pretendia pela via tecnocientífica uma alternativa para a expansão da economia, já preconizada durante o surto cafeeiro em uma sociedade em processo de modernização. 
Figura 24 - Cópia Fotográfica. Terreno da represa Santo Amaro (Guarapiranga) a oeste do rio [Guarapiranga] depois de completada a limpeza da área, 1906

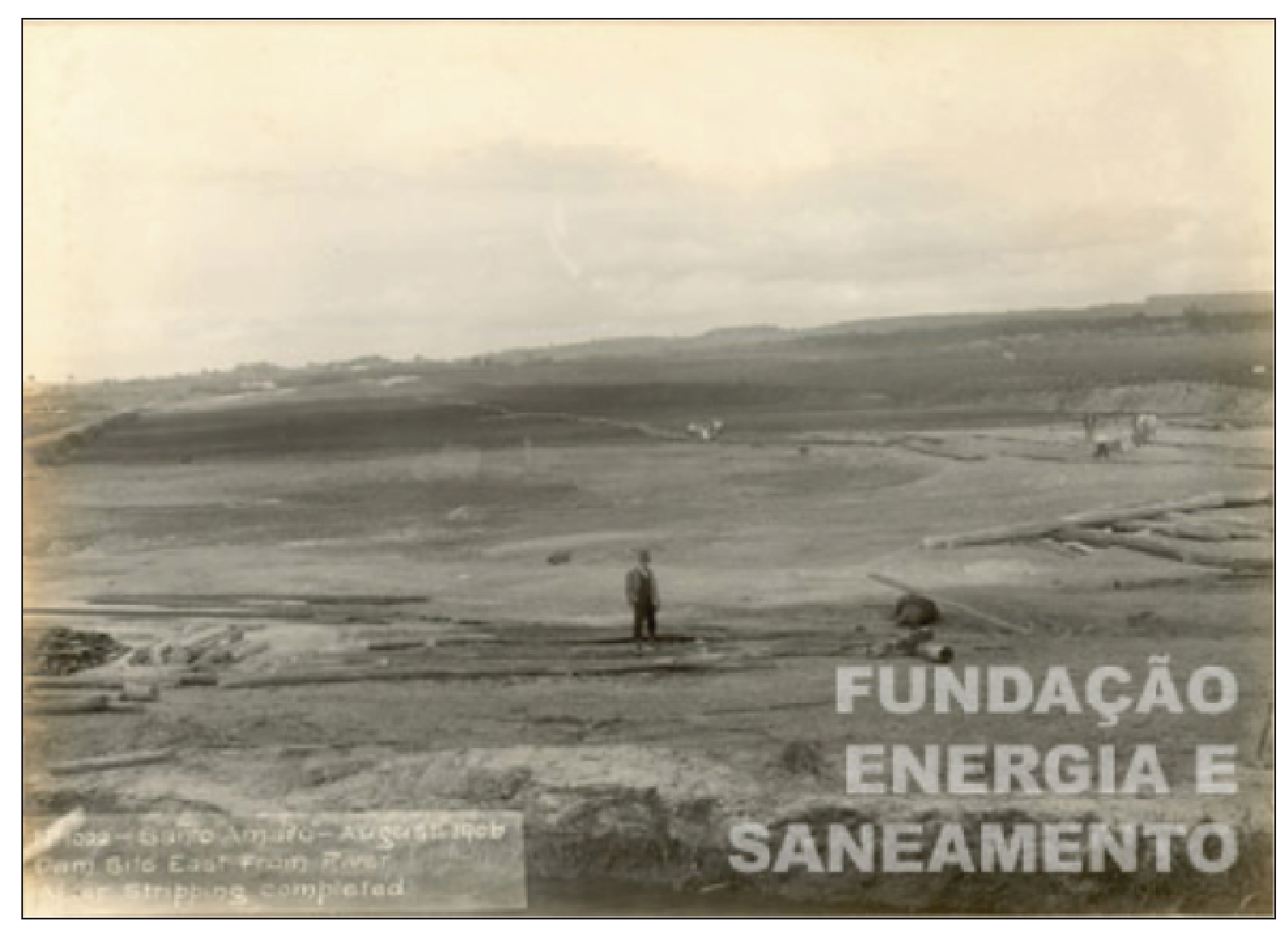

Fonte: Acervo digital da FES (2015). 16,5 x 23 cm [ELE.CEI.SAM.1022]

A implantação de novas técnicas que alteraram significativamente a paisagem em suas relações de construção e transformação do espaço pelo trabalho humano mostra a atuação dos técnicos, como os engenheiros, e os agentes públicos e econômicos de importância política decisiva. Pouco se fala sobre a população de trabalhadores e de moradores do entorno da represa Guarapiranga e de outras obras de grande envergadura da Light na região. Tampouco se encontra sobre a atuação dos artífices e das suas relações com o espaço e de suas efetivas participações nas obras. O fato é que as decisões políticas de alteração territorial em grande escala não passavam por esses segmentos sociais, embora todas as construções da Light, e não só desta, tenham sido efetivadas pelo contingente de trabalhadores e alteraram significativamente a vida das pessoas nas regiões apropriadas pelo grande capital, como reflexos das modificações causadas pela introdução da energia elétrica, novos meios de transporte, na produção industrial e no ritmo de vida, sobretudo urbano. 
Santo Amaro, diferentemente de São Paulo, ficou ao largo das principais linhas ferroviárias e viu a sua relativa importância nas redes comerciais de produtos agropastoris, madeira, lenha e no transporte de muares, diminuir aos poucos. Como nos lembra Jorge (2015), o seu sistema de poder também foi abalado com a transferência de parte do seu território para o controle da Light, que pretendia a construção de uma represa que

[...] parecia não trazer nenhum benefício direto para a maioria dos moradores do lugar. Uma transformação tão radical da paisagem da região, com o surgimento repentino de um grande lago em uma época e lugar ainda pouco acostumado a essas grandes intervenções no mundo natural, não era de forma alguma algo fácil de assimilar (JORGE, 2015, p. 216).

A alteração territorial que aos poucos ia transformando a região em um grande lago, modificou sobremaneira a paisagem tão bem incorporada ao cotidiano das pessoas que lá residiam, criava expectativa em parte da população local sob vários aspectos que se faziam sentir no dia a dia. Na época havia suposições e teorias a respeito dos efeitos maléficos à saúde em consequência da água parada. Segundo Jorge (2015, p. 219), circulavam no imaginário social as teorias miasmáticas, ainda que fossem renegadas pelo saber científico mais atualizado.

A despeito do acúmulo de águas observamos que durante a construção ela ia se acumulando cada vez mais para a formação da represa, em uma região já formada por várzeas que se alagava durante as chuvas.

$\mathrm{Na}$ cópia fotográfica (Figura 25) intitulada originalmente $N^{\circ} 1081$ View of dam from the reservoir. Santo Amaro Dam Construction 20.2.1908, percebemos no primeiro plano a preocupação do fotógrafo em registrar as águas que estavam formando a represa. No centro da foto e de maneira longitudinal há a representação da estrutura de sustentação do represamento das águas, estas notadas em todo primeiro plano da foto, que aos poucos iria submergir o restante da árvore observada na porção à esquerda da foto, um resquício da vegetação da região. 
Figura 25 - Cópia fotográfica. Construção de represa e vista do rio Guarapiranga, 1908

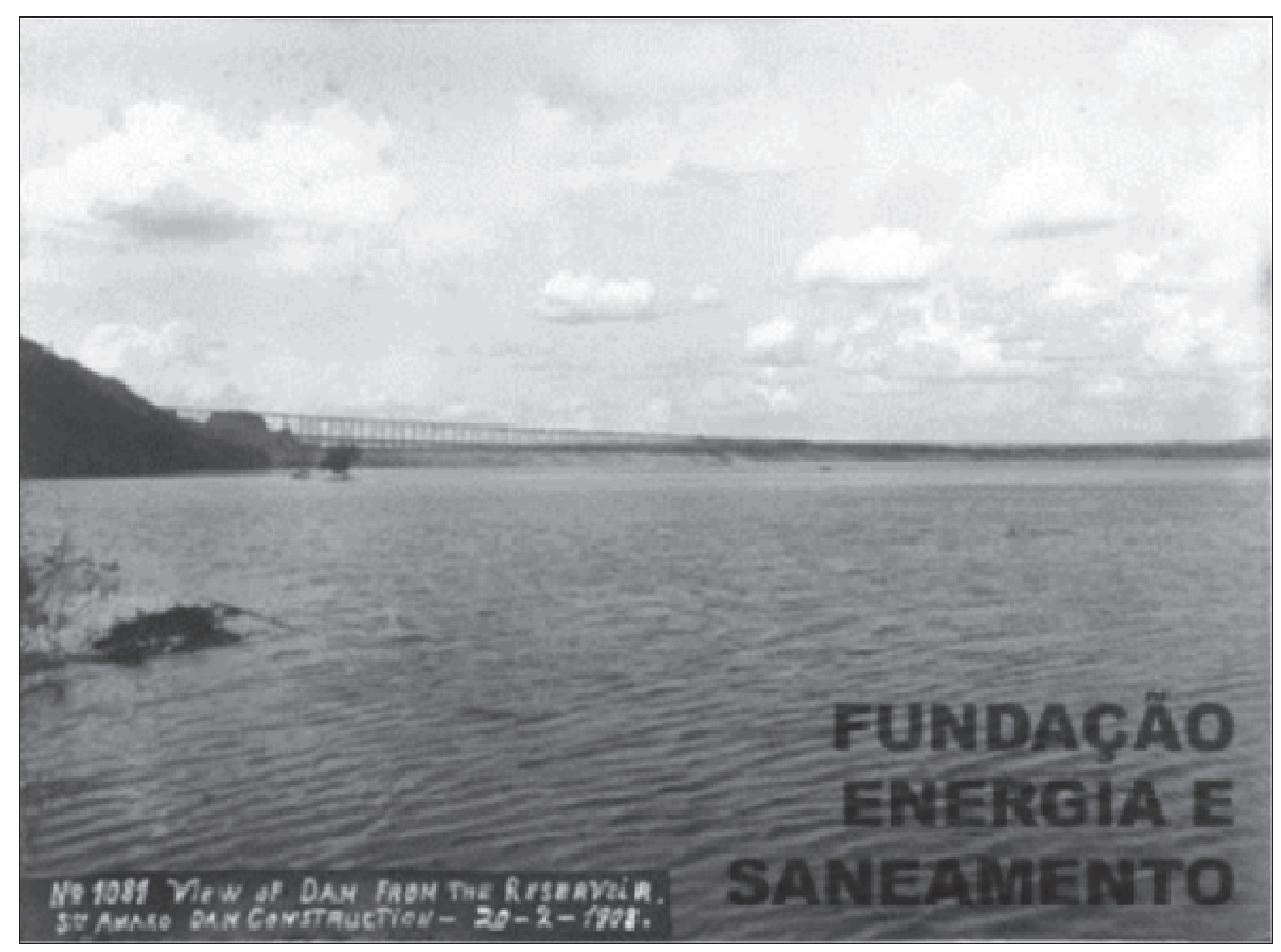

Fonte: Acervo digital da FES (2015). 17,0 x 23,0 cm [ELE.CEI.SAM.1081]

A represa depois de cheia alagaria diversos caminhos e novos deveriam ser criados. A população local não sabia onde e nem a quem iriam beneficiar esses novos traçados e era expectadora das mudanças que ocorriam no espaço por ela habitado. Além do temor por parte da população em morar próximo a um reservatório de água, havia a questão também ameaçadora para a população local quanto à indenização pelas desapropriações das terras necessárias para a construção da represa (PERALTA, 2017), fato similar também foi registrado na construção da usina e represa em Parnaíba. Estas expropriações foram acompanhadas por protestos e manifestações por parte dos habitantes locais que questionavam os baixos preços que a empresa pagava pelos terrenos, constituídos por chácaras e sítios que abasteciam os núcleos urbanos próximos. A polêmica em torno das desapropriações surtiu destaque na imprensa, sobretudo em 1907. 
As divergências eram muitas e, segundo Jorge (2015, p. 220),

alegava-se ainda que a prefeitura perderia a cobrança do imposto territorial de inúmeras propriedades que desapareceriam, o que deveria provocar, também, a queda da produção agrícola. Por outro lado, havia quem afirmasse que a vila ganharia com a represa, que valorizaria as terras da região e levaria mais recursos para lá. O próprio início das obras seria exemplo disso, pois propiciara empregos para moradores de Santo Amaro, o que era benéfico em uma localidade com tantos pobres.

Devemos estar atentos às más condições de trabalho propiciadas pela Light, onde muitos trabalhadores perderam a vida durante as obras de construção de represa (SÁVIO, 2015).

A população local estava pouco instruída sobre o que realmente o represamento das águas proporcionaria a elas, sabiam apenas que um grande lago seria formado. Alguns associavam ao progresso de Santo Amaro, outros ao descaso para com os moradores. Segundo relatado por Jorge (2015), o impasse entre a Light e Santo Amaro foi transferido para a esfera estadual, com tramitação no Legislativo, composto à época pela Câmara dos Deputados e pelo Senado. Em poucos dias foi aprovada a Lei que autorizou a Light a represar as águas do rio Guarapiranga, sem sequer examinarem ou estudarem proficuamente o processo apresentado pelo município de Santo Amaro que exigia atenção aos interesses públicos locais.

$\mathrm{Na}$ verdade, mesmo com o protesto de alguns moradores sobre a construção, "[...] a Câmara aprovava de forma passiva os acordos celebrados entre o Governo do Estado e a Light" (PERALTA, 2017, p. 256), apesar das manifestações nacionalistas em bradar contra a empresa estrangeira que iria alterar o espaço nacional acabado de proclamar a República (1889). Esses brados tentavam romper ou ao menos chamar a atenção quanto aos laços da dominação externa.

Cogitou-se até, por parte de Santo Amaro, que se fizesse a represa na Capital, afinal, esta seria a maior beneficiada com a energia elétrica produzida em Parnaíba. De nada adiantou e o projeto foi aprovado. Os partidários de Santo Amaro, porém, obtiveram o compromisso por parte da Light em substituir a viação a vapor por carros elétricos que fazia a ligação com São Paulo (Vila Mariana), além de uma maior oferta e redução do preço das passagens e também a instalação de iluminação pública por meio 
de lâmpadas elétricas de arco voltaico ${ }^{41}$, colocadas em postes de ferro, em locais de interesse do município (JORGE, 2015, p. 222).

Os motivos de tão rápida decisão da esfera estadual em aprovar a construção da represa estariam, talvez, no fato do Legislativo estadual ser dominado pelo Partido Republicano Paulista, oposição ao município de Santo Amaro, ou simplesmente pelo fato das autoridades municipais quererem afirmar o seu poder sobre algo já decidido. Mas, estas hipóteses não se sustentam facilmente, uma vez que os moradores locais, de maneira geral, não entravam em conflito com os planos da Light.Eles esperavam melhorias urbanas da empresa, como o transporte público mais eficiente até a Capital, a iluminação elétrica e de poderem contar com um espaço para as atividades de lazer, assim que a represa estivesse pronta. As obras da represa foram concluídas em 1909 e os bondes elétricos entre São Paulo e Santo Amaro somente começaram a circular em 1913, conforme nos assegura Jorge (2015, p. 221 e 223).

As imagens iniciais da Light em São Paulo mostram uma cidade em obras em decorrência da implantação dos equipamentos necessários, primeiramente para o funcionamento dos bondes elétricos na região central. Essas e outras imagens retratam a cidade possível e desejada pelas elites dirigentes, tornando compreensível o predomínio das atividades relacionadas com os grupos que detém o poder de intervenção no espaço urbano, pois as imagens evidenciam as suas ações (CARVALHO, 2003, p. 37).

Por meio desta produção visual temos a impressão de que a cidade passa por um intenso processo linear de construção, onde parece não existir oposição manifesta ou latente entre os vários atores sociais envolvidos ou choque entre temporalidades. Os espaços urbanos em sua transformação são valorizados, estas imagens cumprem a função de legitimar uma nova visão de progresso (CARVALHO, 2003; CAVENAGHI, 2000).

\footnotetext{
${ }^{41}$ A lâmpada de arco voltaico foi inventada no início do século XIX, no Reino Unido. É um circuito elétrico com dois bastões de carbono e após o fechamento do arco, possibilita a passagem de corrente elétrica gerando alta luminosidade. Vale salientar, conforme Magalhães (2000, p. 12), que a instalação de lâmpadas a arco no espaço urbano do Rio de Janeiro, mais precisamente na Estação Central do Brasil, ocorreu no mesmo ano (1879) quando da demonstração dessa possibilidade de iluminação. Tal ideia para a iluminação foi instigada pelo imperador D. Pedro II, paradoxalmente considerado pelos republicanos como um símbolo do atraso que deveria ser superado.
} 
As fontes imagéticas permitem-nos a leitura da atuação da companhia Light no espaço físico, a qual o configurava como 'próteses', segundo Santos (2013), ao inserir no território a técnica de uma nova constituição espacial.

$\mathrm{Na}$ imagem seguinte (Figura 26) notamos claramente a diferença do nível de altura: à montante, no lado direito da fotografia, vemos a represa cheia de água, contrapondo ao lado esquerdo da foto, onde o terreno não foi inundado. O fotógrafo centralizou o talude construído pela Light como se quisesse nos dar a nítida impressão do contraste proporcionado pela construção do reservatório. Ao fundo veem-se as ondulações suaves de montanhas com sua cobertura vegetal realçando o talude; à margem inferior esquerda da foto notamos a saída de água pela comporta; na margem inferior à direita temos a legenda original da Light: $N^{o} 1119$ Santo Amaro 10.4.09. Outer slope from west end, sem a assinatura do fotógrafo.

Figura 26 - Cópia fotográfica. Construção da represa de Santo Amaro (atual Guarapiranga). Inclinação externa da barragem vista do extremo oeste, 1909

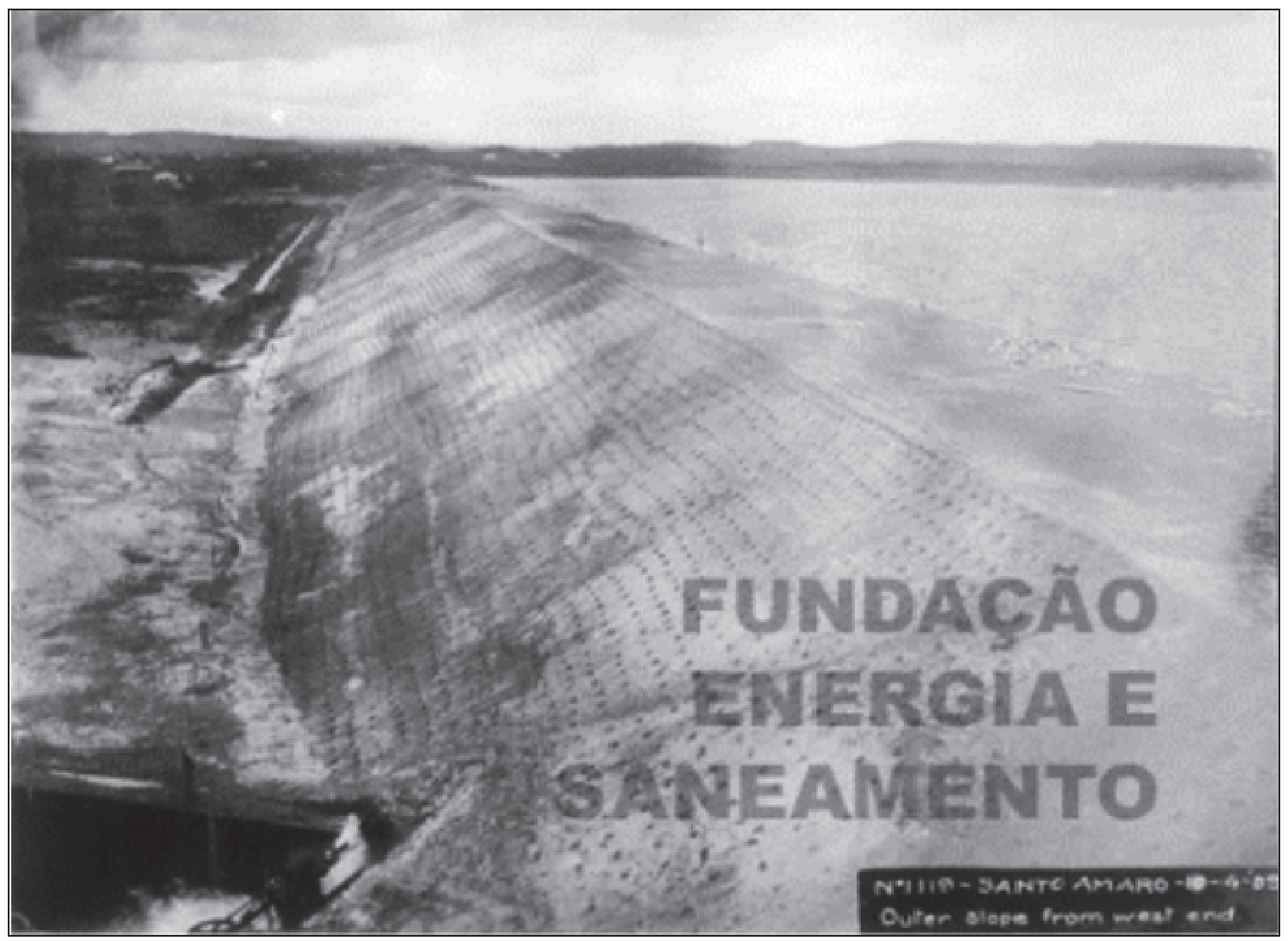

Fonte: Acervo digital da FES (2015). 16,5 x 22,5 cm [ELE.CEI.SAM.001.1119] 
Com a represa já formada (Figura 27), registra-se em seu fundo um forte contraste entre as representações do céu e da terra com o fotógrafo centralizando mais uma vez aquilo que ele pretende realçar na produção da imagem, que é a represa, pois procurou realçar o talude construído dando um destaque maior ao represamento da água, deixando-a se notar em uma maior dimensão no espaço da fotografia, sobretudo em seu lado direito. O fotógrafo procura realçar o represamento das águas, emoldurando-as por terras e dando a impressão de grandiosidade ou infinito da represa na margem direita da foto, onde não há legenda registrada no original da Light. Nesse sentido, nos dizeres de Zanirato (2005, p. 26), a perspectiva adotada pelo fotógrafo interfere na percepção da leitura da imagem.

Ainda, representados no primeiro plano da imagem, há bovinos, cerca instalada ao redor da represa e a marca de rodas de carroça no solo do terreno, indicando-nos a forte presença de animais no cotidiano das pessoas.

Figura 27 - Cópia fotográfica. Construção da represa de Santo Amaro (Guarapiranga). Vista geral da barragem e reservatório. c.a. 1909

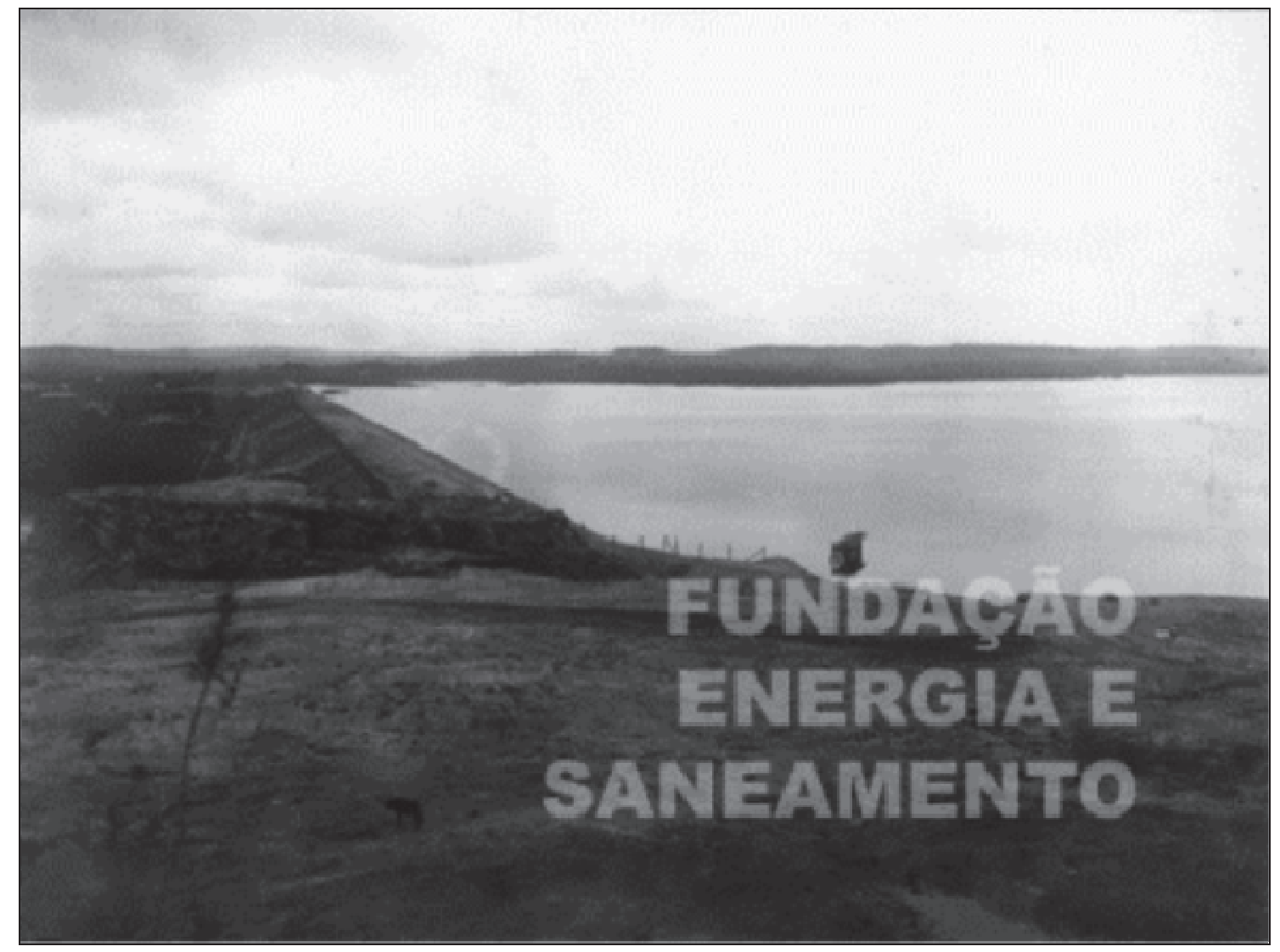


As imagens produzidas da represa adquiriram, também, uma importância para a publicidade, expandindo a cultura visual para além das artes e das ciências. As imagens eram feitas e vendidas com o intuito de divulgar as 'praias' da represa; era um espaço apropriado para a descontração em pleno sítio próximo a urbe, na qual muitas famílias para lá se dirigiam com o intuito de lazer.

Em 1917, década seguinte à construção da represa, foi fundado o São Paulo Sailing Club (mais tarde, São Paulo Yacht Club - SPYC), que aproveitava as águas da represa para propiciar atividades em embarcações à vela, não sendo impeditivo o fato da ausência de energia elétrica e de pavimentação nas ruas de acesso à represa, ironicamente responsável pela produção de eletricidade na região (SOUZA, 1982).

A represa Guarapiranga desde a sua inauguração, em 1909, firmou definitivamente a função recreativa dos arredores de Santo Amaro, reforçada pela instalação do tramway elétrico. Já não era só a Festa do Divino que atraia para Santo Amaro dezenas de pessoas, a represa seduzia visitantes que nos fins de semana para ela se dirigiam, a fim de usufruírem dessa nova área de lazer. Segundo Peralta (2017, p. 395), "O bairro do Socorro, na década de 1920, tornou-se um ponto de atração dos moradores não só de Santo Amaro, mas também de São Paulo, graças aos bares, recreios e restaurantes ali localizados".

Com a formação da represa e Santo Amaro já anexado (1935) à área da Capital, a cidade de São Paulo teve incluída em seu território

[...] uma zona rural vastíssima, que fazia divisas com os Municípios de São Vicente e Itanhaém. No território do exmunicípio [Santo Amaro] estava imensa reserva florestal: rios piscosos, caça abundante, veados de campo e de cerrado e onças (BERARDI, 1981, p. 107).

Os anos da década de 1930 também foram de grandes realizações nas margens da represa, que atraia não só visitantes como também empresários, para os quais a Câmara despachava rapidamente os seus pedidos com pareceres favoráveis, como o permitido à Light para grandes intervenções no município de Santo Amaro em função da construção de uma nova usina hidrelétrica, agora em Cubatão (PERALTA, 2017, p. 397).

Os grupos dirigentes locais estavam vinculados ao poder econômico internacional e o registro fotográfico produzido pela Light pode ter servido, também, 
como um instrumento de aceitação social e ao mesmo tempo de absorção do urbano, entendido como um polo gerador do capital propício a uma prática capitalista mais elaborada, ajudando a evidenciar e impulsionar as transformações que lhe interessava (CAVENAGHI, 2000, p. 2 e 8).

Porém, o modelo de concessão de exploração de energia por parte de grupos estrangeiros, inaugurado com a The San Paulo Gas Company e consolidado com a Light, chega ao fim com a República Velha. O liberalismo econômico de então, a cargo dos poderes locais, é substituído pela centralização do poder de Getúlio Vargas, que passou a gerenciar as ações nessa área e modificou completamente os padrões de relações vigentes. Esse processo culminou com a criação do Conselho de Águas e Energia Elétrica em 1934, responsável por grandes alterações nas articulações do poder estatal com as empresas de energia (SILVA, 2008, p. 22).

Os referenciais de transformação demonstrados pelas imagens da Light são registros que atenderam a uma necessidade e que tiveram na implementação tecnológica o elemento norteador das intervenções.

Assim, o espaço vem se transformando constantemente e a construção da represa Guarapiranga representou para a região a gênese, inserida em um conjunto amplo de articulações políticas, sociais e técnicas de uma época, a grande propulsora da configuração da paisagem e acompanhou os movimentos de ocupação do solo pela transformação do espaço geográfico, que, conforme Santos (2005), tem na especulação imobiliária uma derivação da conjugação de movimentos convergentes, correspondendo a superposição de um sítio social ao sítio natural.

$\mathrm{Na}$ composição imagética (Figura 28), notamos a evolução do processo construtivo da represa, desde o rio Guarapiranga, anterior ao represamento, passando pela vastidão do terreno a ser inundado e a técnica de construção na formação da represa. Parece-nos o desenrolar de um filme fotográfico, com início e fim demarcados pela cronologia dos registros das imagens, onde o discurso abrange o domínio da técnica construtiva por meio do corpus da tomada fotográfica em série. 
Figura 28 - Composição de cópias fotográficas. O rio, o homem, a técnica e a represa. Imagens de 1906 a 1909

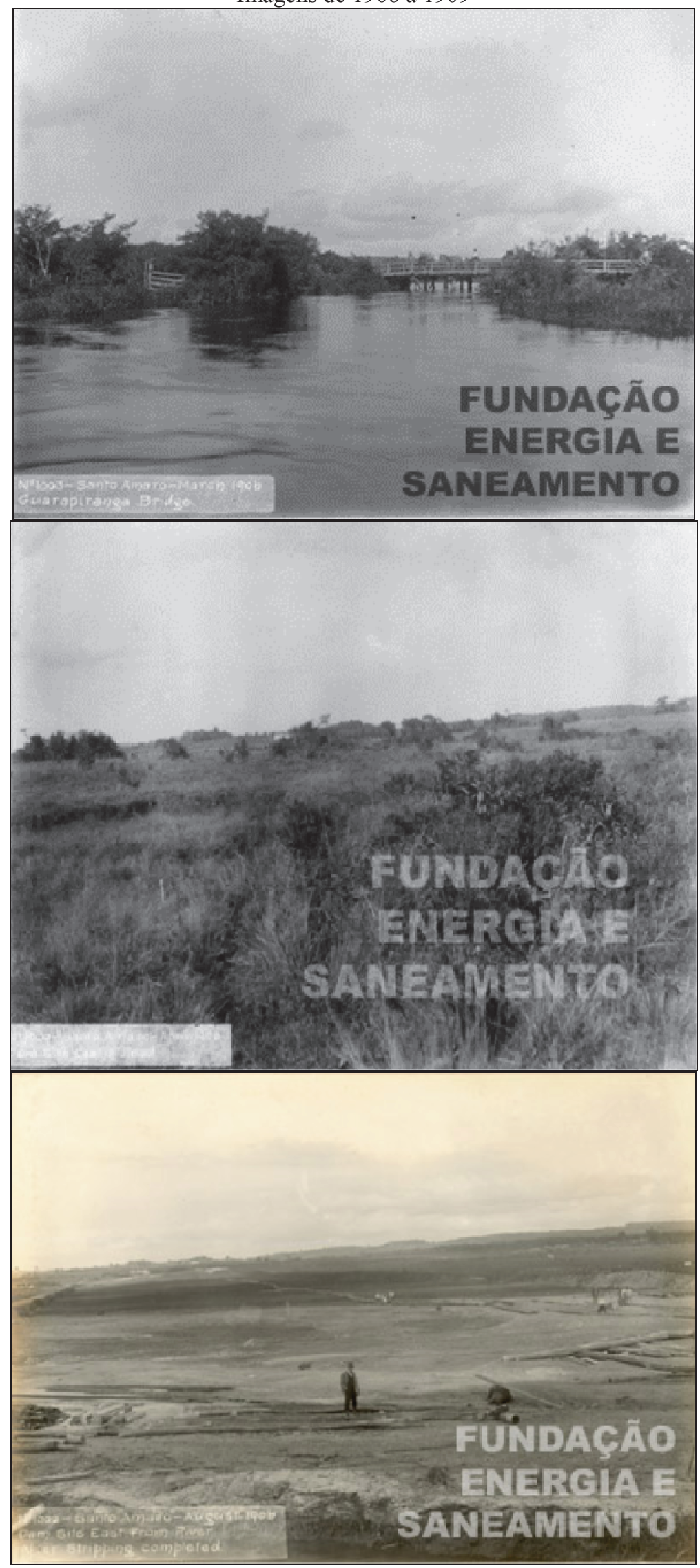




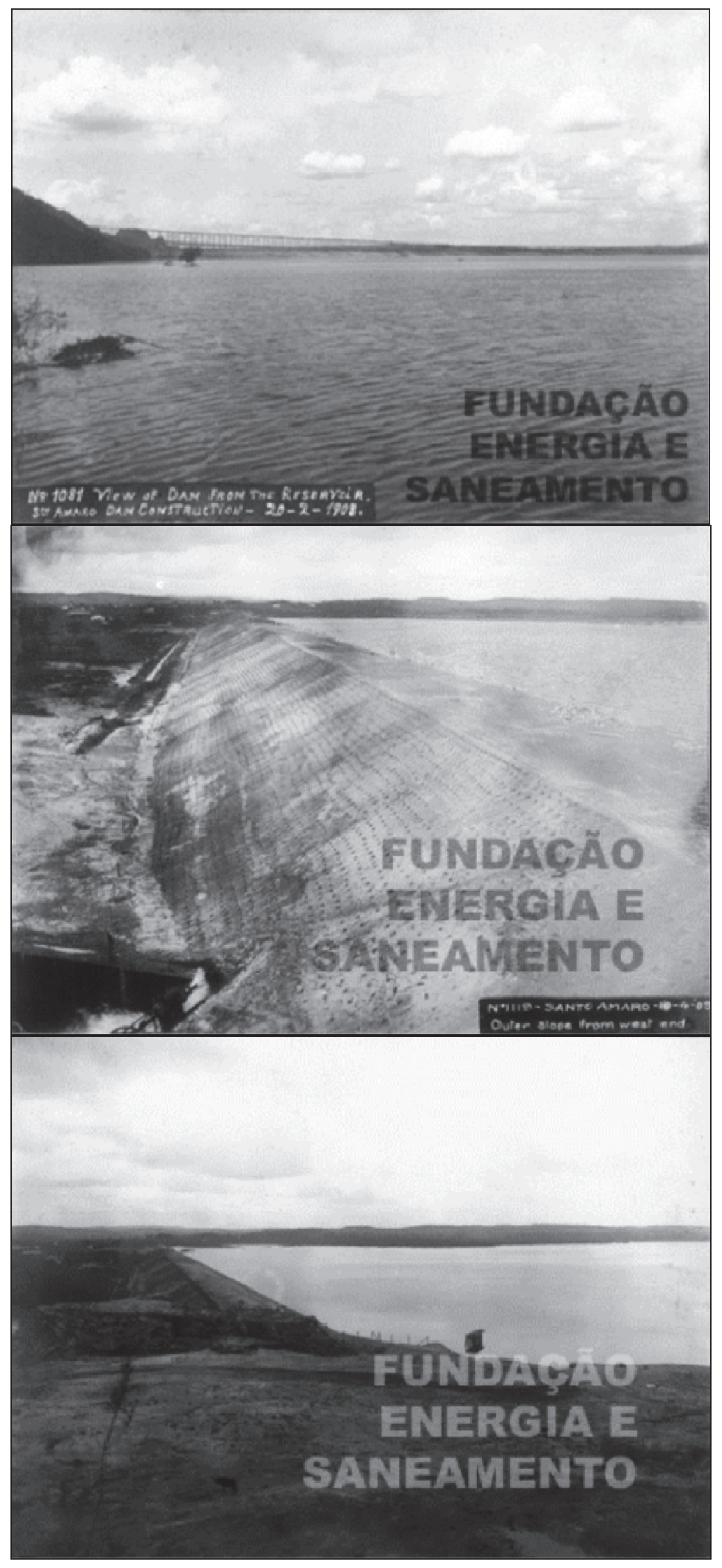

Fonte: Acervo digital da FES (2015). Diagramação do autor (2018). 


\section{3 - Fotografia e tecnologia na construção da represa Guarapiranga}

Em São Paulo, na virada do século XIX para o XX, a fotografia permitiu a seleção de partes da cidade consideradas aptas à representação da "metrópole moderna" que desde 1870 vinha rapidamente passando por intervenções urbanísticas, aceleradas na gestão municipal de Antônio Prado (1899-1911) (FABRIS, 1991, p. 80).

No momento em que as transformações urbanas estavam alterando rapidamente as feições da cidade, o estudo das fotografias é importante para a recomposição da imagem de cenários que, muito transformado, não existem mais. As fotografias antigas que enfocam as estruturas urbanas são fontes documentais extremamente relevantes para a recuperação parcial da ação das técnicas construtivas utilizadas no início do século XX, permitindo, segundo Fabris (1991, p. 160) a compreensão de como se compunham determinados locais da cidade.

A cidade de São Paulo não foi muito fotografada antes de 1870, à época, um acanhado povoado. O fotógrafo Militão Augusto de Azevedo (1837-1905) registrou cenas urbanas de São Paulo de 1860 a 1890, depois destacou-se Guilherme Gaensly (1843-1928), no registro de cenas da cidade.

A fotografia estava presente no registro do novo ou naquilo que representava transformação. Esses registros de obras acabadas ou no acompanhamento de relevantes construções, consolidou-se com a modernização do Brasil.

Prédios oficiais, fontes e chafarizes, praças, estátuas, novas avenidas, intervenções urbanas, demolições 'saneadoras', instalações de redes de transportes, tudo passou a ser registrado com frequência crescente, para culminar na virada do século numa intensidade proporcional ao ritmo das obras.

A contratação desse tipo de registro, tanto podia ser iniciativa das administrações públicas, quanto dos próprios arquitetos, autores das intervenções. Em São Paulo, o mais famoso arquiteto ligado às administrações da virada do século, Francisco de Paula Ramos de Azevedo, fazia fotografar, uma por uma, suas obras - em geral, apenas quando prontas (FABRIS, 1991, p. 165). 
A Light também fotografou muito da sua extensa ação empreendedora, que contribuiu para alterar as feições da cidade, na virada do século XIX para o XX:

A instalação de linhas de bonde e a construção de usinas eram fotografadas sistematicamente em documentos que parecem presididos, mais por um rigor arquivista e cientificista de registrar sua própria ação, do que por seu potencial promocional (FABRIS, 1991, p. 167).

As imagens registravam a prosperidade dos agentes mais expressivos, política e economicamente, na atuação na cidade, sempre aliados às técnicas modernizadoras, cuja dominação e transformação da natureza se configurava em imagem-mercadoria inserida no processo produtivo integrado ao mercado internacional, redimensionando valores e configurando o espaço.

A fotografia, em diferenciação com a pintura, retratava de certa maneira uma natureza industrializada sendo ela mesma produto da economia industrial nascente, ao privilegiar a imagem fabril e urbana, focando "no ideário de difusão do progresso técnico e econômico" com referências ao futuro e valorização das formas artificiais geométricas. Ela retratava "a modernização ao mesmo tempo em que sofre intensamente modificações tecnológicas capazes de aumentar a agilidade e eficiência na produção de imagens" (FABRIS, 1991, p. 224).

Este direcionamento da importância do registro de imagens a partir da técnica fotográfica possibilita a leitura das transformações ocorridas na paisagem de São Paulo com enfoque na formação da represa Guarapiranga para o armazenamento de água e consequente produção hidrelétrica.

Dessa forma

a urbanização no século XIX seria menos fruto da expansão do mercado interno e mais reflexo da expansão do mercado internacional e do desenvolvimento da economia de exportação de produtos tropicais destinados aos mercados europeu e americano do norte e setores subsidiários; [...] Daí também o caráter relativamente instável da rede urbana e o fenômeno característico das 'cidades mortas', que entram em declínio assim que diminui sua participação na economia de exportação (COSTA, 2010, p. 261).

No período de construção da represa Guarapiranga (1906-1909), estavam sendo firmados, no Brasil e no mundo, diversos novos conceitos sobre a produção de energia 
elétrica em escala, a invenção de novos materiais, equipamentos e utensílios para usos doméstico e industrial, novos costumes e serviços urbanos despontavam na chamada modernidade, como o fornecimento de energia elétrica e de água encanada, de transportes, de moradia e de comunicação que configuravam espaços em um ritmo mais veloz, alterando a percepção do tempo natural e impondo ao homem, cada vez mais, uma dinâmica social do tempo.

As cópias fotográficas selecionadas e dispostas neste trabalho narram o processo de construção da represa Guarapiranga e são imagens pouco divulgadas, mas que algumas circularam, à época, nos meios acadêmicos e de divulgação das operações da companhia Light para os seus acionistas, o governo e o público especializado, como os engenheiros. A Light produziu, também, diversas imagens sobre as alterações físicas da cidade de São Paulo e pouco sobre a Guarapiranga, em uma perspectiva comparativa entre ambas.

A construção da barragem das águas do rio Guarapiranga e de seus afluentes consistia em um reservatório de regularização e devia ser edificado a montante da cidade de São Paulo ou em um afluente do rio Pinheiros, que é tributário do Tietê. Estudos mostraram que esta segunda solução era perfeitamente viável, tanto sob o ponto de vista técnico como sob o financeiro, se fosse escolhido o rio Guarapiranga. Assim, resolveu a companhia Light, construir nesse rio uma represa de terra. O início dessa construção foi supervisionada pelo engenheiro estadunidense M.M. Murtaugh, tendo sido terminada a obra pelo engenheiro, também estadunidense, Thomas Berry (SOUZA, 1982).

\section{4 - O desmonte hidráulico na construção da represa}

As obras da represa foram feitas pelo processo hidráulico, utilizando o método de hidromecanização também denominado desmonte hidráulico, que consistia no jateamento de água sob forte pressão para o desmonte de encostas à esquerda do rio Guarapiranga,

com transporte da água e do material erodido, por calhas, para a formação de 900 metros de aterro. Toda a barragem atingiu, na sua configuração original, 1.640 metros de extensão e altura máxima de 15 metros. Era a maior obra do gênero, à época, em todo o hemisfério sul (ARAÚJO, 2014, p. 45). 
No artigo publicado pela Revista Polytechnica de São Paulo em 1908, intitulado “As obras da 'Light' em Santo Amaro", o autor diz que o processo geral de construção da represa foi originário dos Estados Unidos, mais precisamente na Califórnia, denominado hydraulic system, no qual se observou "a resistência e impermeabilidade adquiridas nos depósitos formados pelos restos terrosos dos minérios de ouro, arrastados na água de lavagem destes" (GREMIO POLYTECHNICO, 1908, p. 136).

No Brasil colonial do século XVIII, segundo Pataca (2017), a técnica de extração de minérios em Minas Gerais já utilizava o desmonte hidráulico dos morros por meio da utilização de rodas d'água, uma tecnologia proveniente da China, e com muitos trabalhadores africanos escravizados. Não havia energia elétrica na época e o sistema hidráulico usado para a separação do ouro consistia no desmonte do solo e a utilização de tanques de decantação, também observado em outras regiões do Brasil.

A técnica está portanto difundida não só em regiões distintas como também de épocas diferentes, adaptadas às tecnologias contemporâneas de cada momento, como no caso da construção da Guarapiranga e a utilização da energia elétrica como força motriz para o desmonte hidráulico.

Antes de iniciar propriamente o desmonte dos morros pela força da água, todo um suporte deveria ser construído, a fim de possibilitar o acúmulo de sedimentos no local apropriado, como vemos na imagem (Figura 29) com a legenda original da Light em inglês: $N^{o} 1043$ - From near auxiliary gates towards north monitor in middle left. S.Amaro, April, 22, 1907, na base inferior à esquerda da foto e com a assinatura do fotógrafo $B$. Klofs na base inferior à direita. No primeiro plano da cópia fotográfica há o registro do terreno após a retirada da vegetação mais densa e do seu conveniente aplainamento. As fundações de suporte da barragem estavam sendo armadas para limitar a área a ser ocupada pelas águas, como demonstrado na parte central da foto em posição longitudinal. Em cima da fundação observa-se uma máquina que auxilia na construção da estrutura e também o longo cano a acompanhá-la em sua extensão e posicionado acima da estrutura ainda mais baixa, sendo enfocado na perspectiva longitudinal no centro da imagem. 
Figura 29 - Cópia fotográfica. Construção da represa de Santo Amaro, (atual Guarapiranga), 1907

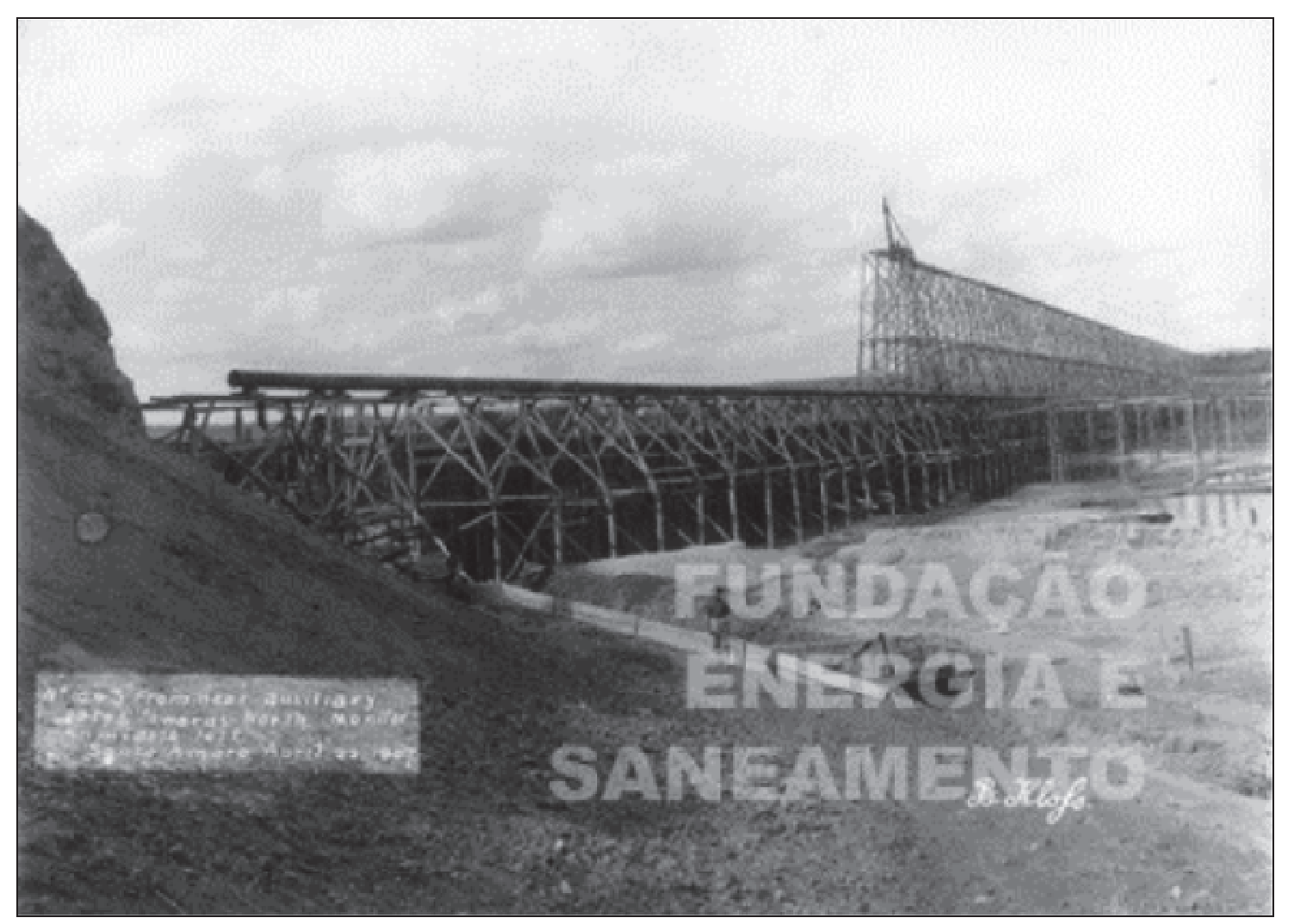

Fonte: Acervo digital da FES (2015). 16,5 x 22,5 cm [ELE.CEI.SAM.001.1043]

A área que ocuparia a base da barragem foi limitada de ambos os lados e em toda a sua extensão por pequenos muros de terra ou de feixes de madeira. À medida que a terra se misturava com a água, resultado do desmonte hidráulico, constituía-se um efluente que por decantação ia sendo transportado por condutores ao local da barragem, sendo despejado onde as paredes da barragem se formariam.

à medida que se eleva a barragem, se vae sempre limitando a sua crista, que deverá receber nova materia de sedimentação, com paredes lateraes dispostas de modo a formarem com as anteriores as rampas preestabelecidas (GREMIO POLYTECHNICO, 1908, p. 137, grafia original).

Essa transcrição também é observável na imagem fotográfica (Figura 30) com a legenda original da Light em sua base inferior à esquerda: $N^{o} 1057$ S. Amaro. Dam Construction - Sept. 1907. View from top of hill at west-abutment towards the east. Nota-se a tomada centralizada, do primeiro plano dirigindo-se ao fundo da foto, da 
estrutura inclinada, do condutor e das calhas que levam a água com o solo erodido para a formação da parede da barragem de terra por decantação dos sedimentos. Ao lado direito da foto vê-se a água sendo represada aos poucos em contraposição ao lado esquerdo da imagem, ou a jusante do rio. A imagem capta pequenas casas ao fundo com a vegetação e o horizonte, como se quisesse emoldurar a fotografia e realçar a água e a construção da represa no contraste monocromático do registro imagético.

Figura 30 - Cópia fotográfica. Construção da represa de Santo Amaro e vista do rio Guarapiranga, 1907

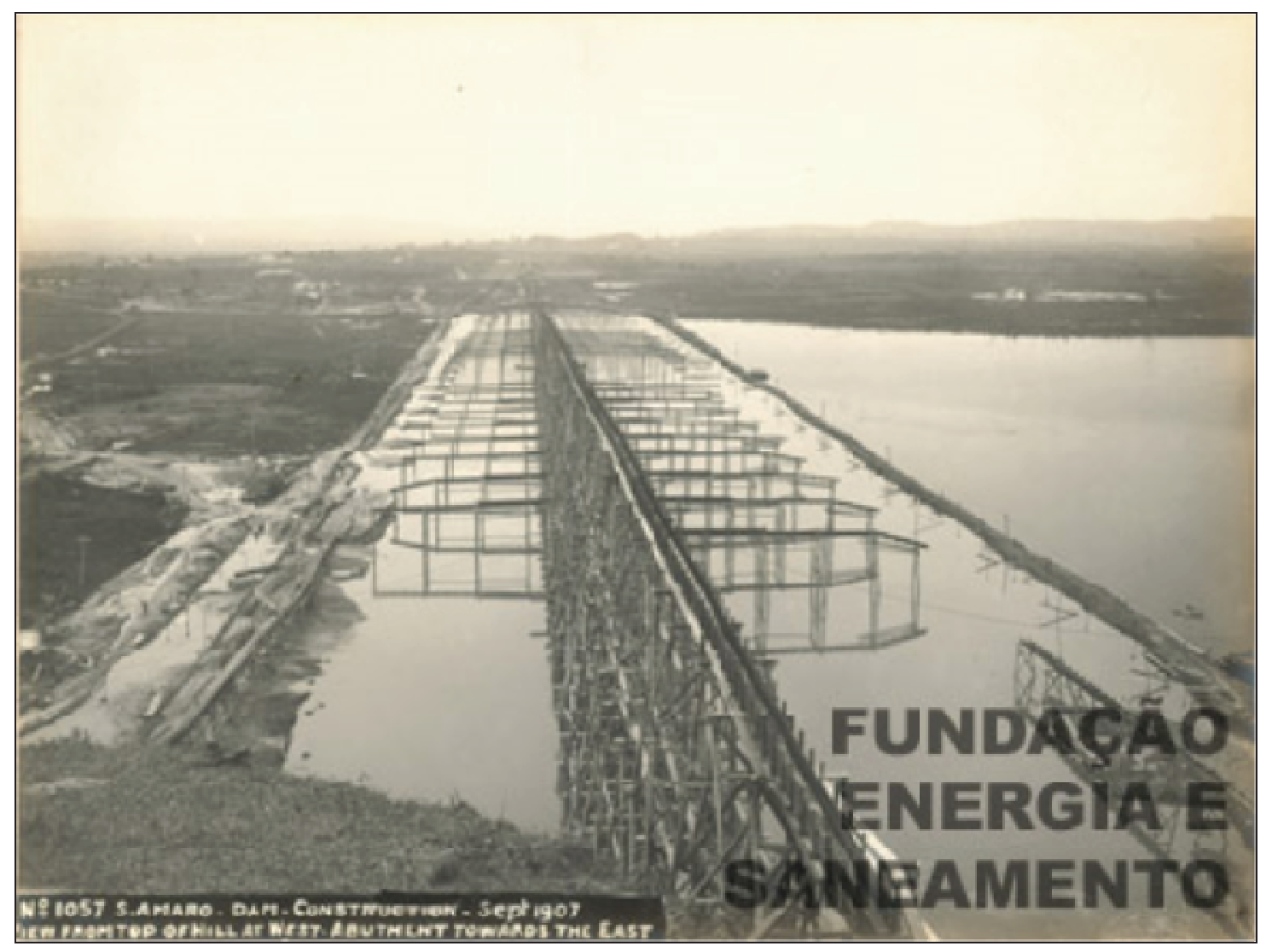

Fonte: Acervo digital da FES (2015). 17,0 x 22,5 cm [ELE.CEI.SAM.001.1057] 
Ainda, sobre o transporte dos sedimentos terrosos para a construção da represa, temos a informação de que:

Os materiaes em suspensão na agua se vão depositando desde que ela pare, mas como o seu lançamento se faz proximo aos paramentos da barragem, a parte mais grossa e densa ahi fica, sendo assim os sedimentos tanto mais finos quanto mais centraes.

O nucleo é portanto constituido de material muito compacto, homogeneo e impermeavel pois consiste quasi só de argila essa parte mais fina.

Deve a sedimentação ser feita em bastante profundidade, assim a agua perde rapidamente sua velocidade, as materias grossas se depositam $\operatorname{logo} \mathrm{e}$ as mais finas vão por percolação colmatando essa parte já atterrada.

$[\ldots]$

Apesar do grande numero de construcções neste genero, ha ainda poucas experiencias a respeito, assim, é ainda desconhecida a capacidade de transporte da agua, e pouco se sabe sobre qual seja a melhor proporção que entre si devem guardar os materiaes transportados (GREMIO POLYTECHNICO, 1908, p. 137-138, grafia original).

Localizada a cerca de $2 \mathrm{~km}$, além da então vila de Santo Amaro, a represa tem área de 1.600 metros de comprimento, cortando o seu eixo o curso norte-sul do vale do rio em ângulo reto. Do lado leste, a inclinação até o rio é suave, ao passo que do lado oeste o terreno é íngreme e levanta-se a uma altura de 40 a 50 metros acima do rio. A altura máxima é de cerca de 18 metros, largura no alto, 15 metros e taludes de 1 para 2 do lado de fora e 1 para 3 do lado do tanque, represando mais ou menos 200 milhões de metros cúbicos de água (SOUZA, 1982).

Existe uma relação de distinta dimensão e captura da imagem entre a fotografia e o desenho técnico (Figura 31), que se complementam, como demonstrado nas cópias fotográficas da construção do talude e do desenho assinado pela Revista Politécnica, localizado na parte inferior à direita da figura (Rev. Polyt), que representa as medidas da construção do talude e fazia parte de um texto técnico educativo escrito por engenheiros e pensado para este mesmo público em formação e atuação profissional. 
Figura 31 - Desenho técnico das dimensões transversais do talude da barragem da Represa do rio Guarapiranga, 1908

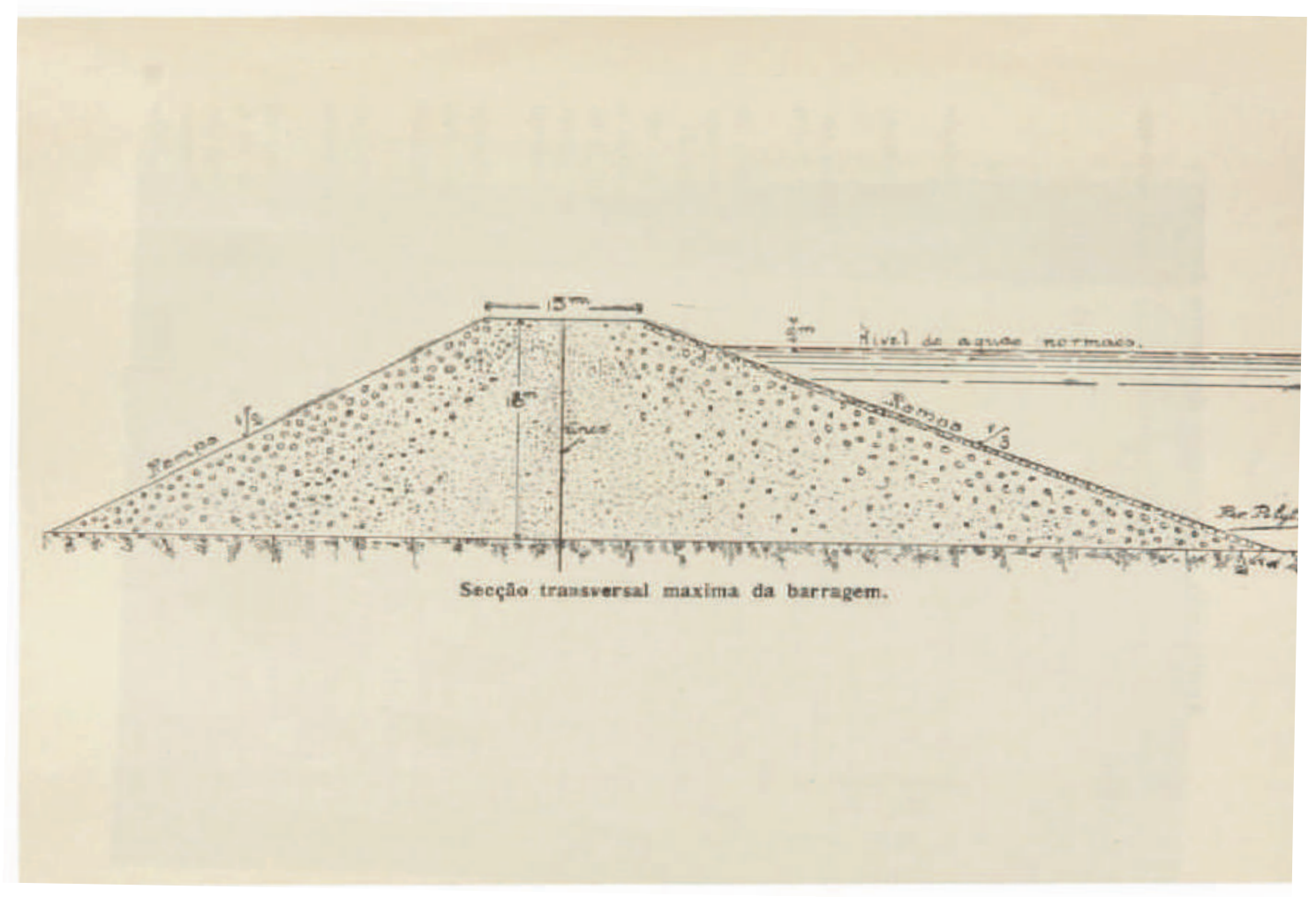

Fonte: Revista Polytechnica, São Paulo, v. 4, n. 21, p. 139, abr./maio, 1908.

Como já relatado, para a construção da Guarapiranga utilizou-se o método denominado de hidromecanização ou desmonte hidráulico a fim de descompactação das encostas pela força da água e com o transporte dessa água e do material erodido por calhas, para a formação dos aterros de terra que constituiriam as paredes da barragem, como observado na sequência das cópias fotográficas apresentadas.

Primeiramente observa-se (Figura 32) o morro sendo desbastado por um forte jato d'água. $\mathrm{Na}$ porção centralizada da foto está o jorro de água que na monocromia preto e branco da fotografia permite-nos ver claramente o contraste. A água sob pressão desbasta o morro, há a presença de um poste com fios de energia elétrica, diferentemente de épocas anteriores, onde a força motriz era provida dos movimentos das rodas d'água.

Ao fundo da imagem está a representação com pigmentação clara do céu contrastando com o morro, onde em seu canto superior à direita está a figura de um homem cuja silhueta nos dá a dimensão da encosta e do jato d'água. Em sua legenda 
original da Light, no canto inferior à direita da foto, temos em inglês: $N^{o} 1067$ Showing character of material High Level Borrow Pit. S.Amaro. Dam Construction - October 15 $-1907$.

Figura 32 - Cópia fotográfica. Construção da represa de Santo Amaro (Guarapiranga). Retirada de aterro, 1907

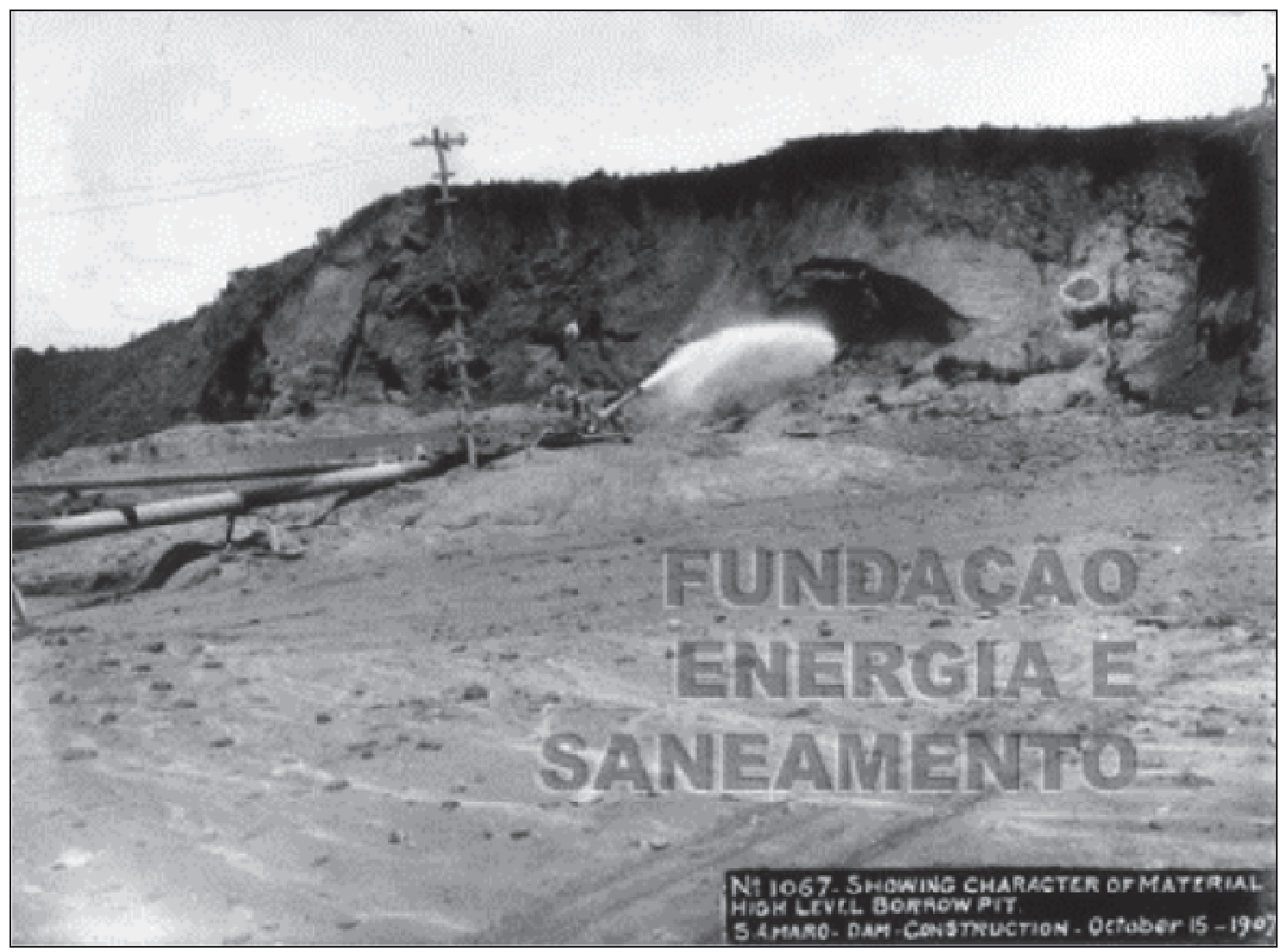

Fonte: Acervo digital da FES (2015). 16,5 x 22,0 cm [ELE.CEI.SAM.001.1067]

$\mathrm{Na}$ foto seguinte (Figura 33) e na mesma ordem encontrada no acervo digital da FES e registros originais da Light, temos centralizado ao fundo da foto e, de maneira diminuta, o jato d'água sendo empregado para o desmonte da encosta e as águas sendo transportadas pelo conduto inclinado e tendo seus sedimentos carregados e depositados por calhas ao longo da parede de reforço visível como um espelho d'água preenchendo praticamente toda a imagem. A terra era retirada de apenas uma extremidade da obra, ou seja, do seu lado mais elevado. A legenda na base inferior da foto apresenta: $N^{o} 1068-$ View from - booster pump platform towards the nort. S.Amaro. Dam Construction Nov. $1-1907$. 
Encontramos na Revista Polytechnica uma explicação técnica, que nos auxilia no entendimento da construção:

Para conduzir a agua foi construída uma armação de madeira situada ao longo do eixo da barragem e que pouco a pouco vae ficando enterrada com o seu crescimento. A inclinação dos conductores centraes é de $3 \%$, que permitte correr perfeitamente o effluente carregado até com mais de $60 \%$ de terra. Sua vasão é de cerca de 20 pés cubicos (109 litros) por segundo. Esses conductores centraes distribúem o effluente em toda a extensão da barragem por meio de conductores a elles normaes e collocados de espaço a espaço (GREMIO POLYTECHNICO, 1908, p. 140, grafia original).

Por se tratar de uma atuação técnica de engenheiros no território, as fontes utilizadas expõem informações e escritos de ordem metodológica, mensurável e controlada por esses engenheiros na reestruturação física do espaço geográfico. As fotografias serviam de registros para a complementação de seus relatórios escritos e para a divulgação em impressos especializados a um público definido e orientado.

Figura 33 - Cópia fotográfica. Construção da represa de Santo Amaro (Guarapiranga). Vista geral da plataforma de reforço da barragem, 1907

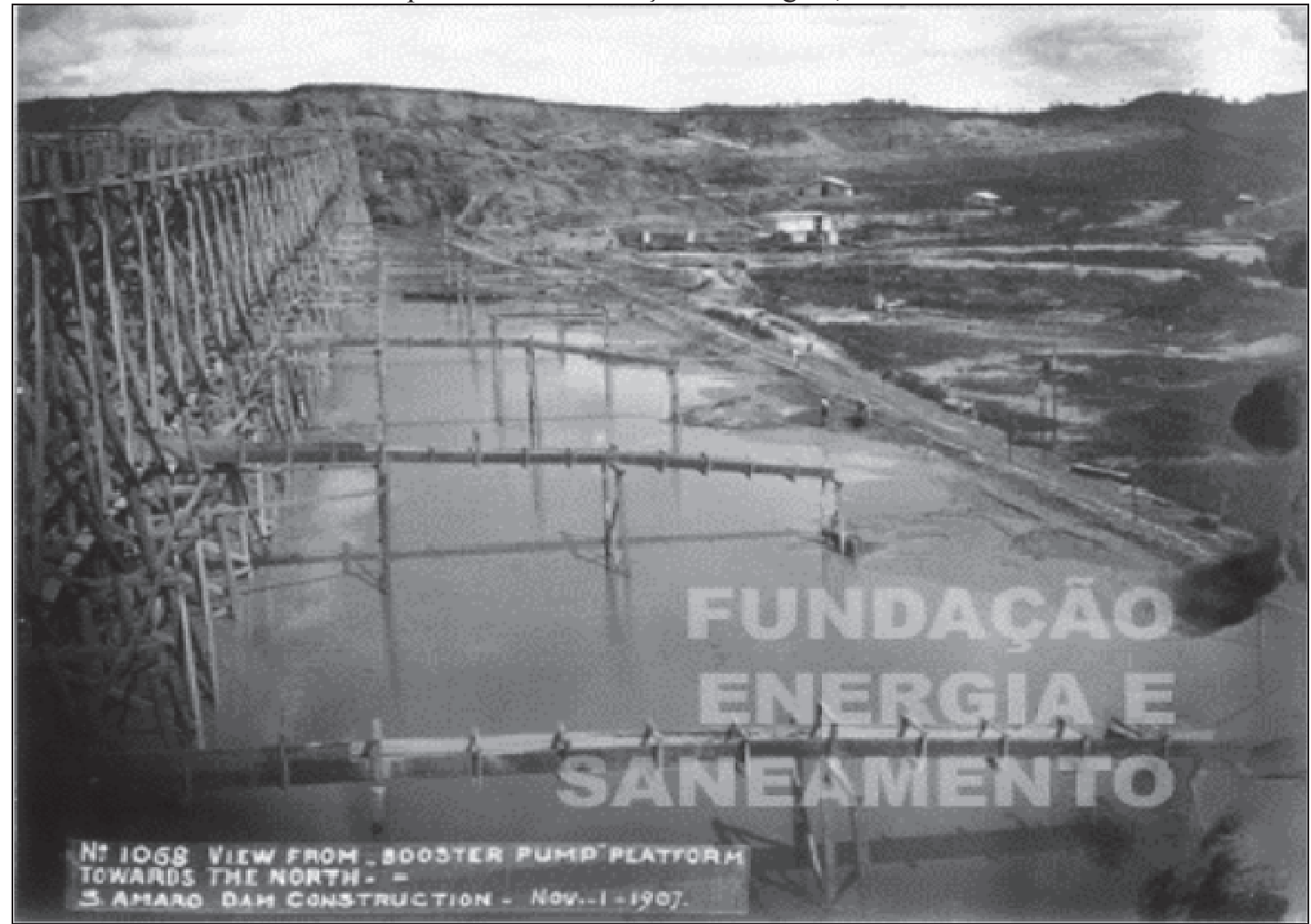

Fonte: Acervo digital da FES (2015). 16,5 x 22,0 cm [ELE.CEI.SAM.001.1068] 
Na sequência das apresentações fotográficas (Figura 34) vemos os vários níveis da encosta sendo desbastados pela força hidráulica movida à eletricidade e orientada pelo homem localizado em sua margem superior à direita, com maior visibilidade do jato d'água nesta representação, e com a seguinte legenda na base inferior: $N^{o} 1069-$ North side Borrow pits, showing lower, intermediate \& higher levels with monitor working on latter. The axis of spillway passes near to the two light poles in the middle of the picture. S.Amaro. Dam Construction. Nov. 1 - 1907.

O jato d'água era

produzido por uma bomba rotativa aspirante - calcante de 4 phases, accionada por dous motores electricos de 700 cavallos vapor, aos quaes é ligada eixo a eixo. Fornece 500 pés cubicos dagua por segundo sob pressão media de 120 libras por pollegada quadrada (8,4 atmospheras). A conducção forçada até o local do jacto se faz em tubos de 15 e 11 pollegadas, feitos em chapas de aço rebitadas em espiral. A bocca do esguicho, que tem 4 pollegadas de diametro e é facilmente manejavel por um homem, chega a agua com a respeitavel pressão de 50 a 80 libras por pollegada quadrada, ou 3,5 a 5,6 atmospheras.

Por meio deste jacto se obtem com a maior presteza, simplicidade e economia o desmonte e transporte do material para os sluice (conductores), bastando para todo esse serviço um só homem, o que dirige o esguicho (GREMIO POLYTECHNICO, 1908, p. 141, itálico da revista, grafia original). 
Figura 34 - Cópia fotográfica. Construção da represa de Santo Amaro (Guarapiranga). Vista geral do local de retirada de aterro mostrando os níveis baixo, intermediário e alto, 1907

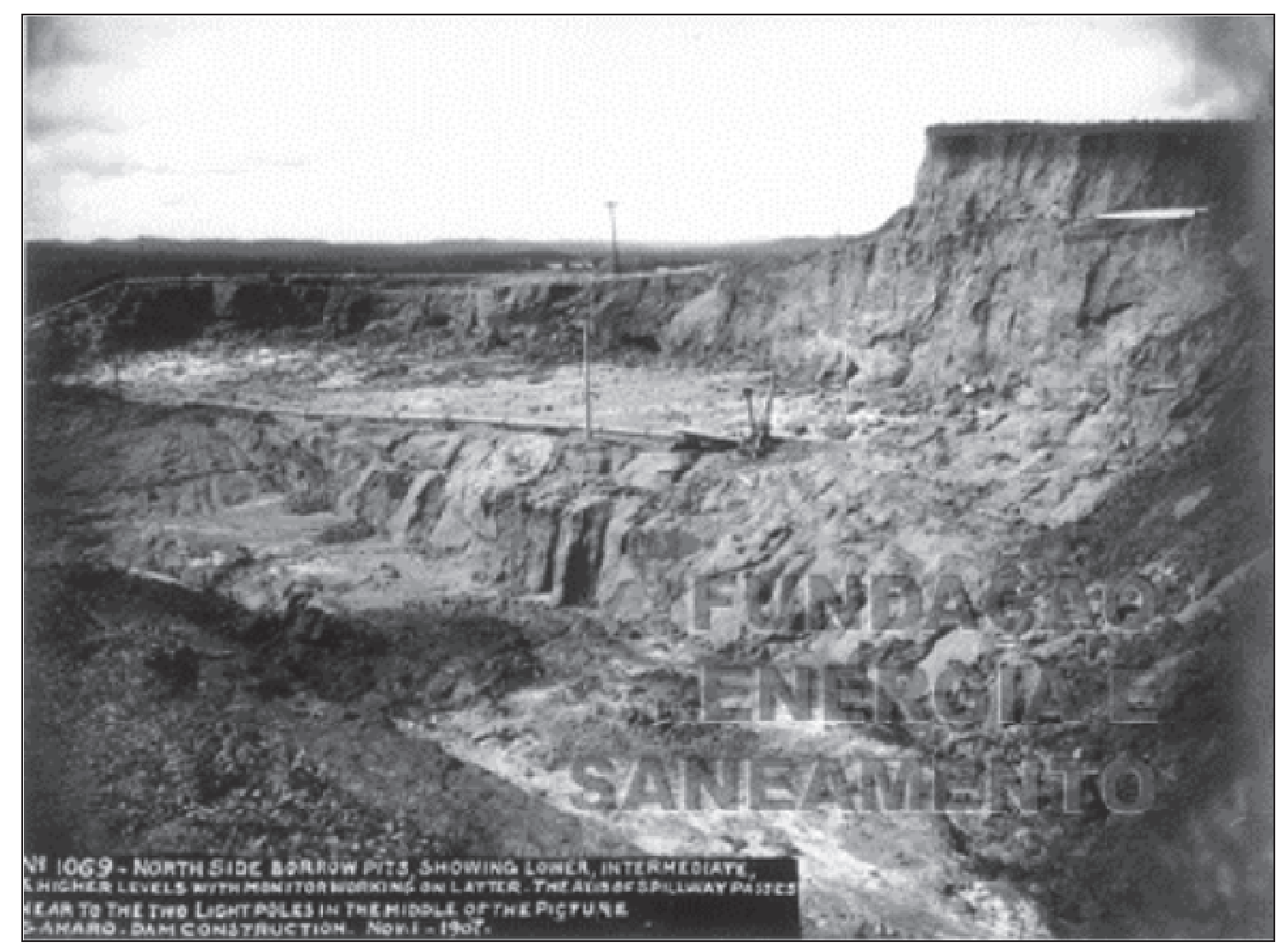

Fonte: Acervo digital da FES (2015). 16,5 x 22,5 cm [ELE.CEI.SAM.001.1069]

Na imagem seguinte (Figura 35) o nível mais alto da encosta já se encontra desbastado, em comparação com a fotografia anterior. Nesta cópia o fotógrafo capturou o desmonte do morro à medida que a terra ia sendo transportada pela água, além de permitir visualizar a estrutura de madeira que forma o conduto e os canos que conduziam a água em virtude do contraste monocromático entre claro e escuro, tal representação do cenário está posicionada no canto esquerdo da foto, o que supõe a percepção do escoamento superficial da água e dos sedimentos erodidos pelas calhas que os transportam. Notamos também, ao fundo da imagem, a fiação elétrica aérea. As imagens são melhor visualizadas por meio do arquivo digital somente disponível na FES.

A legenda original da foto no arquivo é como consta na imagem: $N^{o} 1072-$ Borrow pits of the lower, intermediate upper levels north side. Stakes marking the west edge of the spillway may be seen near the end of the pipe in the centre \& at the right of 
the middle pole on the upper level. S.Amaro. Dam Constr. Dec. 1-07, deixando clara a preocupação da empresa em relatar a sequência de sua atuação na construção da represa e no progresso da cidade.

Figura 35 - Cópia fotográfica. Construção da represa de Santo Amaro (Guarapiranga). Vista geral do local de retirada de aterro mostrando os níveis baixo, intermediário e alto, 1907

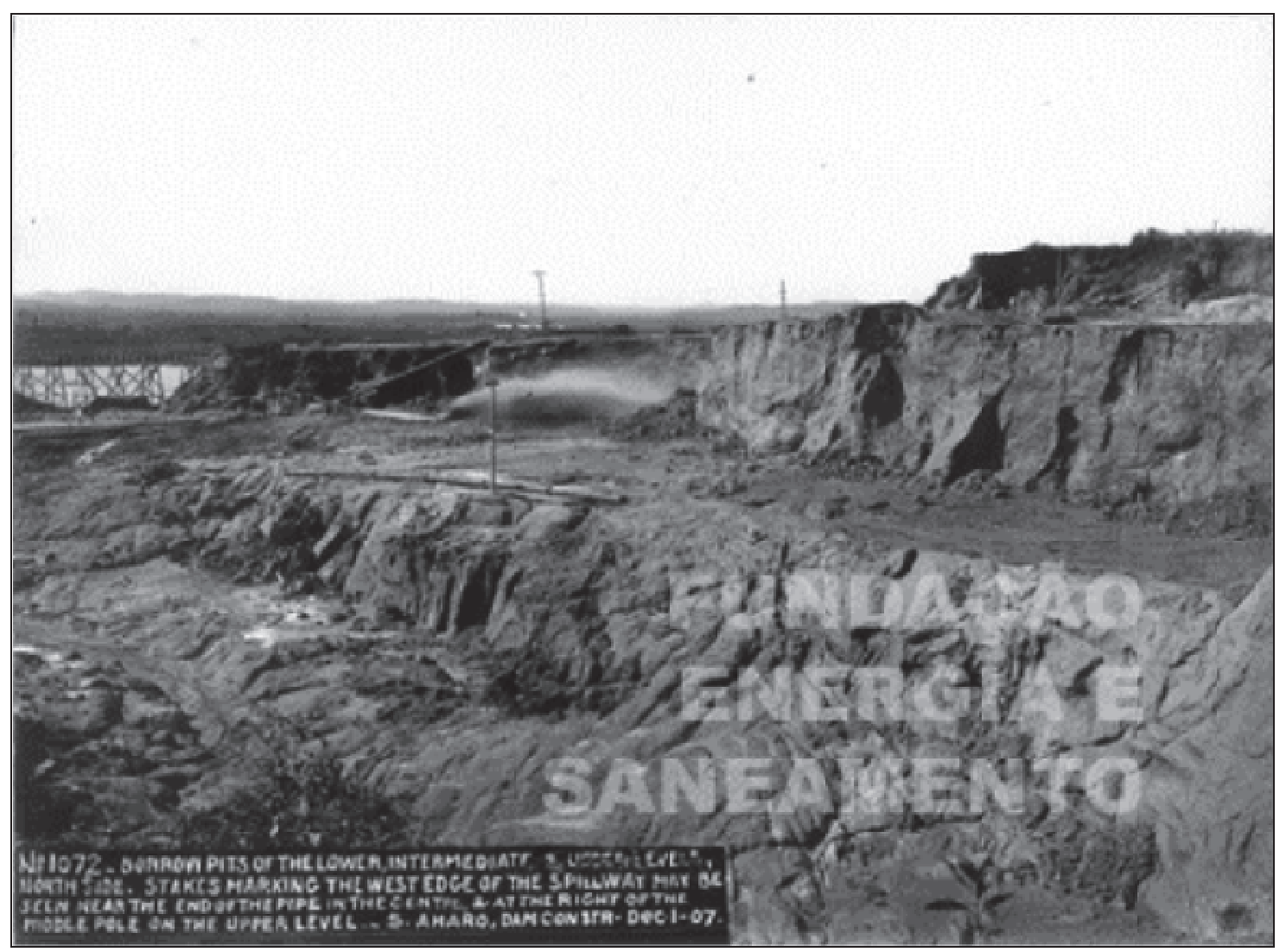

Fonte: Acervo digital da FES (2015). 16,5 x 22,5 cm [ELE.CEI.SAM.001.1072]

Esse processo construtivo de barragens seria conhecido desde a antiguidade egípcia, segundo Jorge (2015), que ainda relatou ser o desmonte do solo transportado até o local definitivo da construção da barragem. "Com a construção da represa de Morning Star, na Califórnia [EUA], em 1870, essa técnica ganhou notoriedade e foi utilizada largamente até meados dos anos 1940” (JORGE, 2015, p. 212, itálico do autor). 
A Light divulgava em jornal que tal processo era frequentemente usado em outros países na construção de açudes para fins de irrigação e os resultados eram excelentes, pois a terra depositada ficava mais sólida do que se conseguia por qualquer meio mecânico (JORGE, 2015, p. 213).

Como vimos, o processo construtivo está no aproveitamento do solo que é transportado pela água e

[...] de se depositar quando ella perde sua velocidade: é exactamente o processo natural de formação de terrenos por sedimentação. Os optimos resultados obtidos, desde cerca de 20 annos com este systema de construcção, conduziram a sua adopção systematica nos Estados Unidos e outros paizes, especialmente para as grandes barragens [...] (GREMIO POLYTECHNICO, 1908, p. 136, grafia original).

A barragem do rio Guarapiranga foi uma grande obra de engenharia para o Brasil e, segundo Jorge (2015), constituiu o primeiro aterro hidráulico do país, formando o maior lago do Estado de São Paulo. Tal fato chamava a atenção e possibilitava uma maior visibilidade da atuação dos engenheiros, categoria profissional em expansão no período, que se utiliza de tal feito para estudos e aperfeiçoamento de suas atividades.

O processo de desmonte hidráulico utilizando o uso de energia elétrica era eficiente e foi empregado também, em anos seguintes, para uma das maiores intervenções urbanísticas da cidade do Rio de Janeiro. Mais uma vez estavam os engenheiros à frente dessa empreitada registrada em fotografias. Tratava-se da demolição do Morro do Castelo, lugar de primeira ocupação da cidade, constituindo em um dos pontos de sua fundação no século XVI (PEREIRA, 2016, p. 140).

Em 1906 o Castelo era ocupado por muitos cortiços, configurando um cenário bem diferente do proposto para tal espaço. O então prefeito do Rio de Janeiro, Carlos Sampaio $^{42}$, com o propósito de abrigar as comemorações do Centenário da Independência do Brasil, em 1922, iniciou a demolição do Morro do Castelo, uma das últimas áreas de moradia popular no centro da cidade. Essa intervenção consistia na ideia de um Brasil moderno associado às mudanças urbanas para a Capital do país,

42 Carlos César de Oliveira Sampaio (1861 - 1930), prefeito do Rio de Janeiro entre 1920 e 1922. 
sendo os terrenos loteados e vendidos por empresas que promoviam as chamadas melhorias (PEREIRA, 2016, p. 142).

$\mathrm{Na}$ cópia fotográfica (Figura 36) notamos a tomada de visão do fotógrafo em registrar no centro da imagem a técnica hidráulica para desagregação do solo que formava o morro. Houve o registro da ação humana direcionando os jatos d'água sob os olhares atentos de pessoas que acompanhavam o processo. No lado direito da foto notamos, como nas imagens da construção da Guarapiranga, um poste de energia elétrica, muito presente nas cópias fotográficas. A montanha era considerada uma imensa barreira ao progresso e

era enfrentada com algo que parece tão pouco potente: água [...] Os homens, em primeiro plano, avançavam pela cratera e as construções apareciam de forma secundária, numa indicação de algo que iria sucumbir. Na verdade, Alberto de Sampaio [1870 - 1931, autor da fotografia] documentava a técnica empregada: há canos de água, o cavalete e os trabalhadores. [...] o contato com a cidade aparece de forma indireta [...] (PEREIRA, 2016, p. 144 -145).

Figura 36 - Cópia fotográfica. Demolição do Morro do Castelo, Rio de Janeiro, 1921

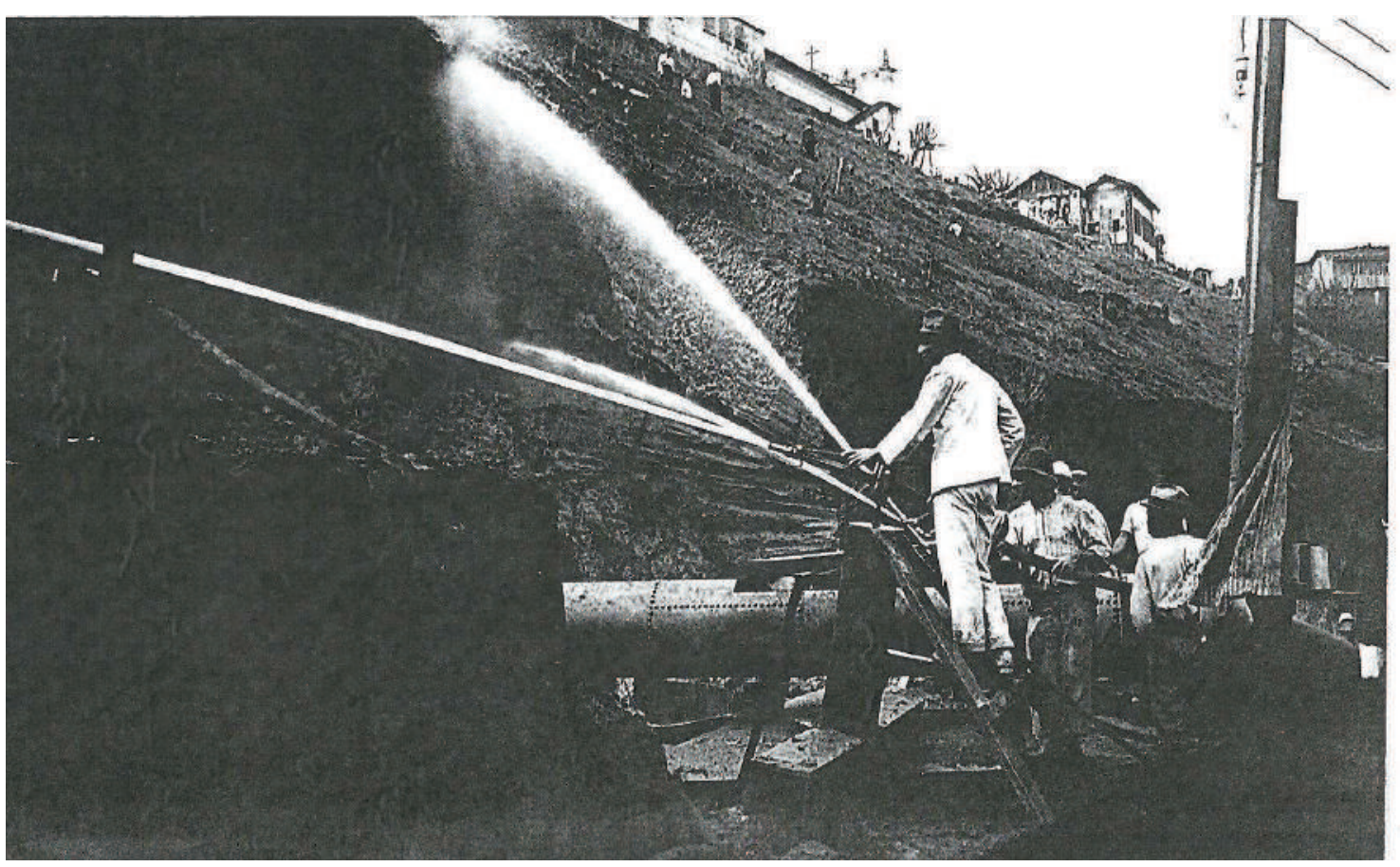

Fonte: Pereira (2016, p. 191).

Foto: 13,5 x 8 cm. 14 set. 1921, por SAMPAIO, Alberto de. 
O processo de demolição começou em 1921 por iniciativa direta da prefeitura e com a utilização de uma máquina escavadora. Posteriormente foram contratadas empresas privadas e

em outubro de 1921 foi assinado o contrato entre a prefeitura, os banqueiros americanos Dillon \& Read e a firma de engenharia Kennedy \& Co. A partir desse momento, a força hidráulica usada no arrasamento do morro passou a ser empregada de forma bem mais intensa (PEREIRA, 2016, p. 143).

Mais uma vez notamos a relação existente nas intervenções empregadas em Santo Amaro/São Paulo e a Capital do país, as iniciativas de empresas privadas nas suas relações com o poder público e a atuação dos engenheiros nas técnicas de alteração da paisagem.

A presença humana nas cenas, tanto em Guarapiranga como no Morro do Castelo, aparece de forma secundária. Os trabalhadores das obras têm as suas ações registradas e estão ali em função das atividades desempenhadas pelos equipamentos técnicos (PEREIRA, 2016, p. 144).

Em outra imagem fotográfica expressiva da transformação da paisagem do Rio de Janeiro (Figura 37), cuja tomada nos dá a impressão mais nítida do Morro do Castelo sendo destruído, vemos a preocupação do fotógrafo em registrar os fortes jatos d'água descompactando o morro e tendo aos poucos as casas desmoronando, representadas como entulhos no centro da foto e permitindo prospectar as demais construções que iriam ser corroídas pelo avassalador processo que desabrigou quatro mil pessoas de suas residências (BURGI, 2016).

Todo o material retirado do morro foi utilizado para aterrar áreas litorâneas e possibilitar a ampliação e ocupação urbana. Para Turazzi (2006) essas eram fotografias de engenharia, ou seja, registros de obras das intervenções na cidade, e tinham importância para reforçar e divulgar os progressos da nação brasileira em empreendimentos ligados à própria engenharia. 
Figura 37 - Cópia fotográfica. Demolição do Morro do Castelo, Rio de Janeiro, 1922

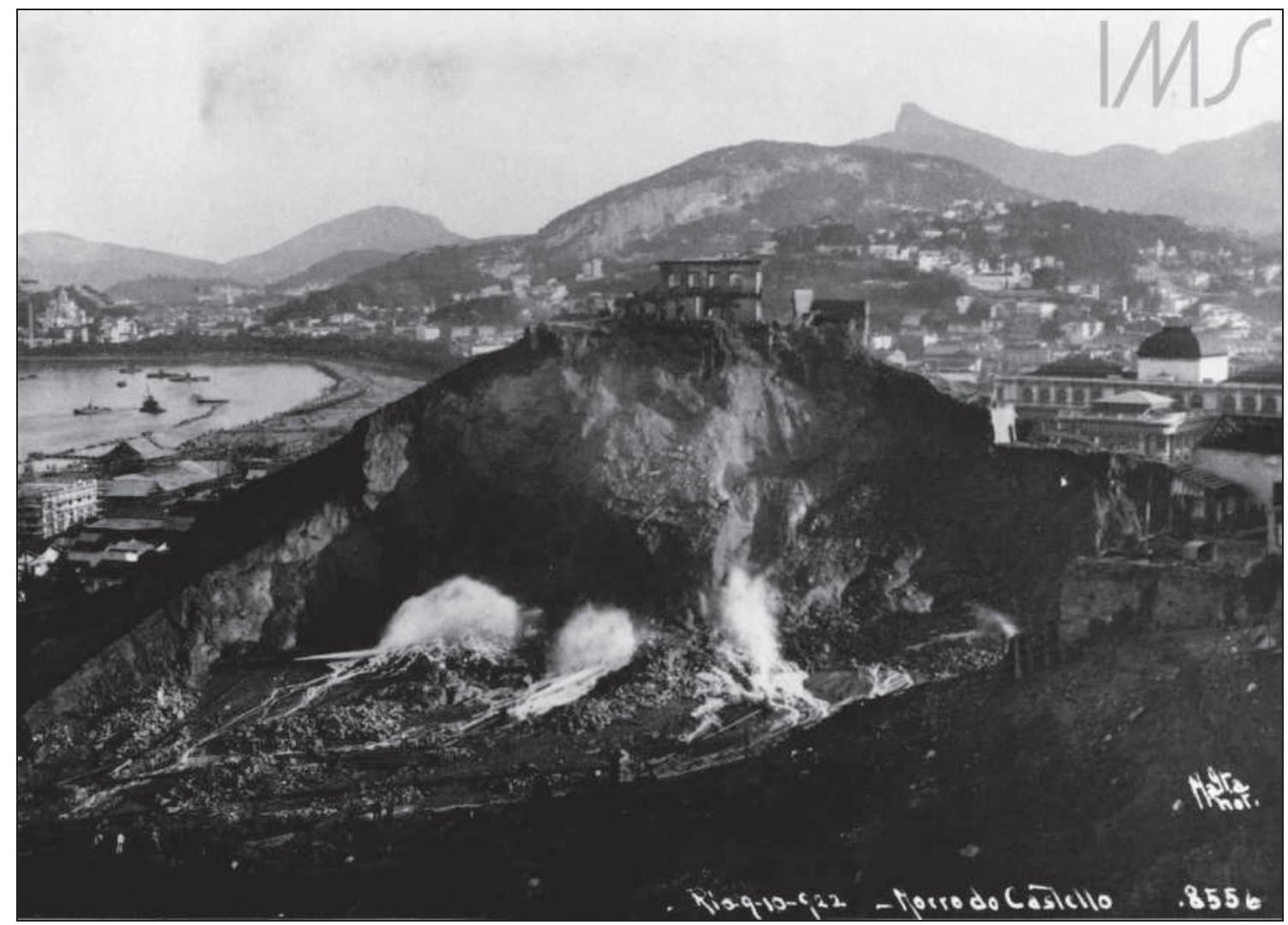

Fonte: Instituto Moreira Salles (IMS). Acervo fotográfico digital, 2018. Foto: 9 out. 1922, por MALTA, Augusto. 
Figura 38 - Composição de cópias fotográficas. Desmonte hidráulico em Guarapiranga (1907) e no Morro do Castelo (1921)
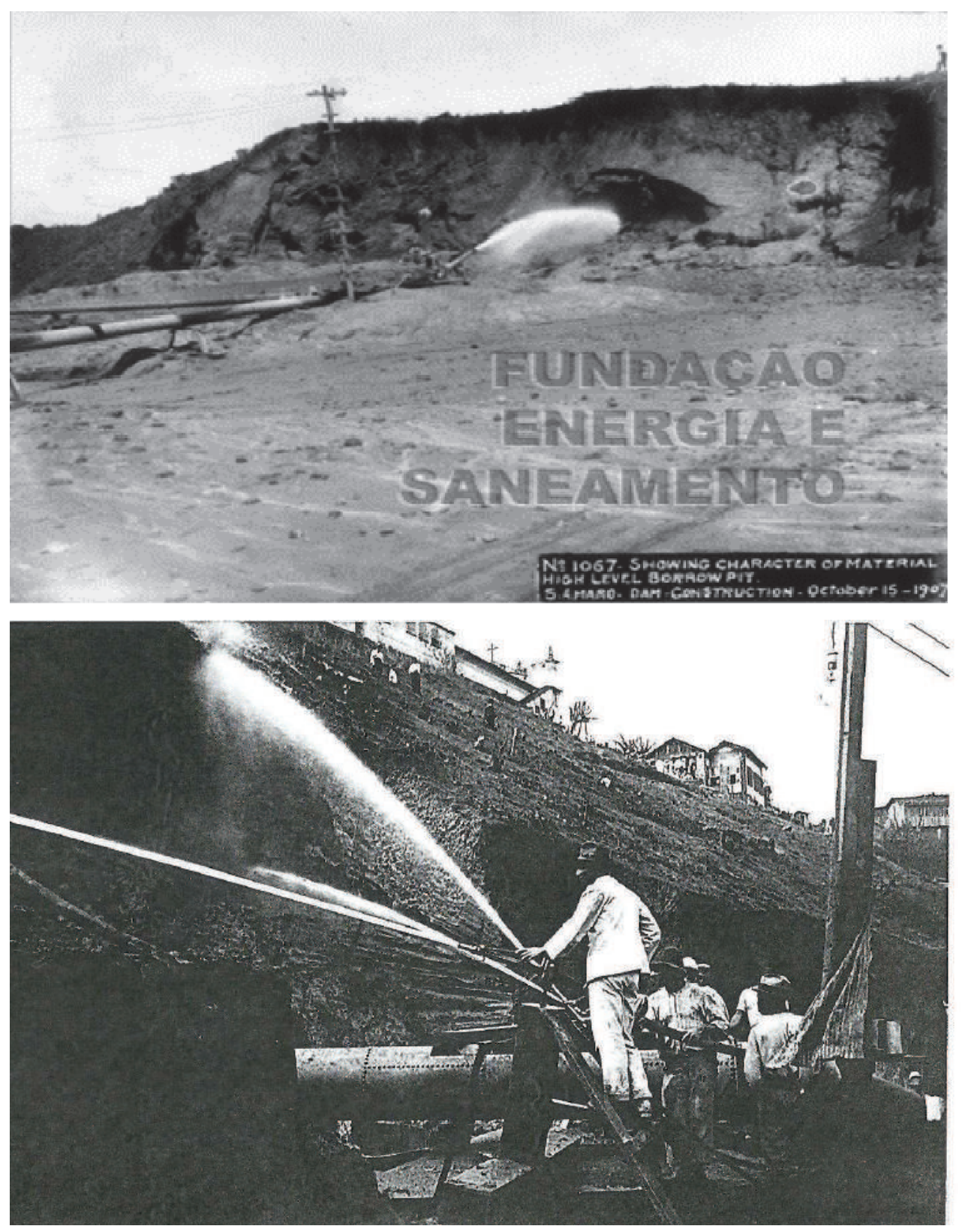

Fonte: Pereira (2016, p. 191) e acervo digital da FES (2015). Diagramação do autor (2018). 


\section{5 - Elementos em concreto armado na represa}

Contudo deve-se salientar que somente uma estrutura de terra compactada não suportaria a força de escape da água ao se projetar para além da represa, no intuito de aumentar a vazão no rio Tietê. Uma estrutura mais sólida deveria ser construída, sobretudo na passagem das águas e situado justamente sobre o talvegue do rio Guarapiranga. Assim, quando houvesse a necessidade de mais água para suprir a deficiência do Tietê, ela sairia por um túnel em três arcos de cimento armado com barras de aço cravadas de espaço a espaço até a superfície, passando a água por baixo da barragem e munido de dois sistemas de comportas, a fim de garantir maior segurança e evitando o perigo da falta de coesão entre a terra da barragem e a alvenaria do túnel, que poderia levar à ruína da barragem (GREMIO POLYTECHNICO, 1908, p. 142).

Tal construção dos túneis mencionados está disposta na imagem a seguir (Figura 39), embora não a colocamos na ordem cronológica da sequência dos registros fotográficos orientados pela Light, optou-se por divulgá-la nesta ordem a fim de criar maior consonância ao texto escrito e às demais imagens apresentadas.

Nela lemos a legenda na base inferior à esquerda: $N^{\circ} 1035$ - Santo Amaro December 1906 Entrance End Diversion Tunnels Finished Concrete Work ${ }^{43}$ e a chancela do fotógrafo que capturou a imagem à direita: B. Klofs Phot. S.Paulo, R. Direita 43, registrando os três túneis de concreto e as paredes de contenção em ambos os lados do rio. Um poste de madeira está representado na foto e é uma figura constante em várias outras imagens da Light. No leito do rio, na entrada dos túneis, nota-se a presença dos moldes de madeira para os arcos de concreto armado, ripas, barris e outros objetos de madeira, além de escadas posicionadas para acessá-lo.

\footnotetext{
43 O dia exato do registro fotográfico não está visível na imagem e não possui documento arquivístico redigido comprobatório da data na FES.
} 
Figura 39 - Fim do trabalho nos túneis de concreto no Rio Guarapiranga, 1906

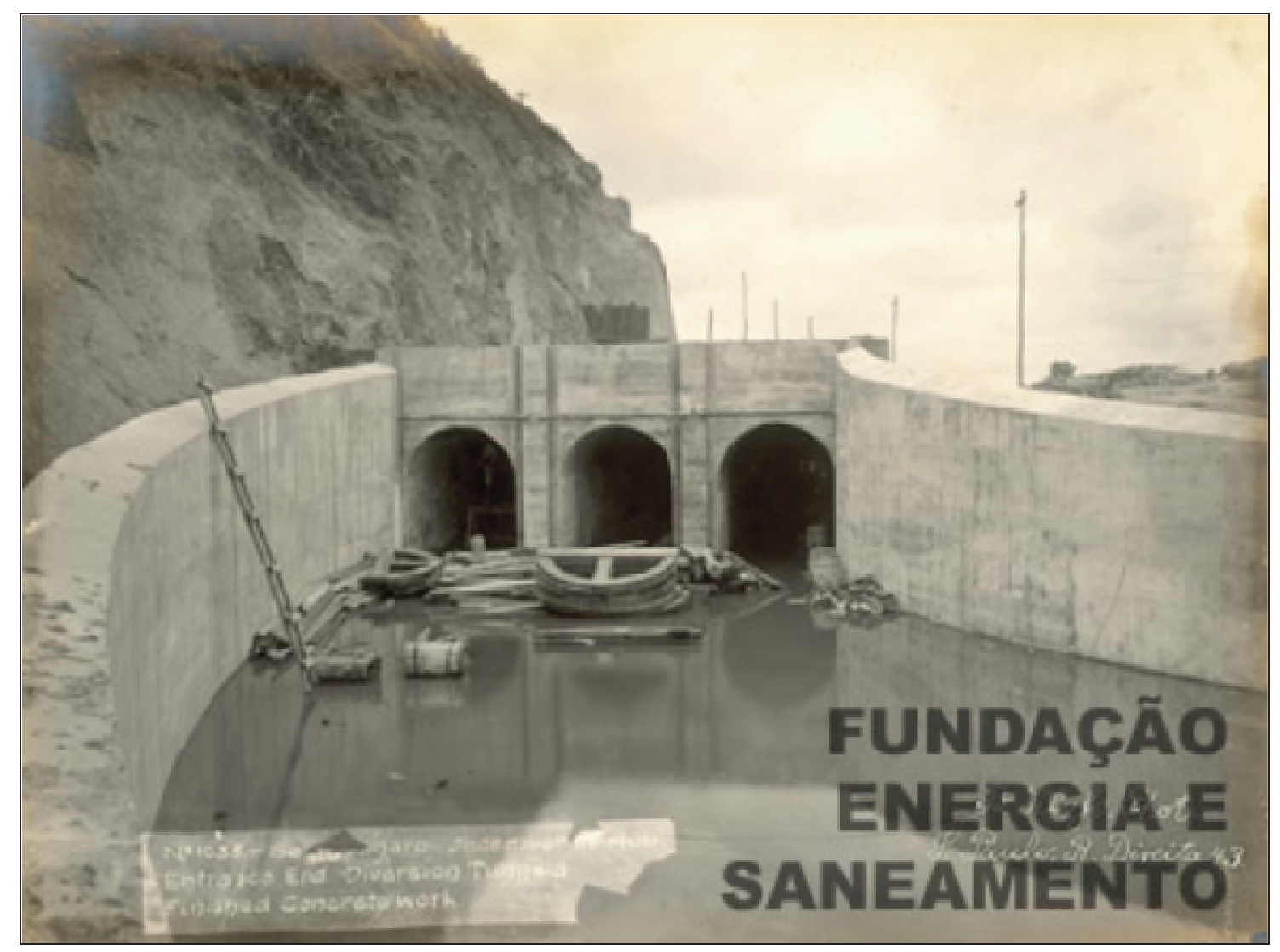

Fonte: Acervo digital da FES (2015). 17 x 22,5 cm [ELE.CEI.SAM.001.1035]

As técnicas construtivas que compunham o concreto armado estavam entre as “ações empíricas [...] e a sistematização desse conhecimento em noções definidas, formando o que se denomina por ciência” (FREITAS, 2011, p. 56).

Assim, essa nova tecnologia construtiva só passou a ter sua validade reconhecia após sua validação teórica e experimental e a transformação das práticas pelos cálculos matemáticos, ou seja, da transformação da técnica em ciência por meio da ação e posicionamento do racionalismo dos engenheiros, que a divulgava nas publicações dos periódicos especializados ligados às Escolas Politécnicas de São Paulo e do Rio de Janeiro (FREITAS, 2011, p. 99).

No início do século XX, o concreto armado estava distante de ser uma tecnologia construtiva de fato no país, embora ela tenha sido aplicada precisamente em 1901, na construção de um túnel na Estrada de Ferro Central do Brasil, na qual a nova tecnologia construtiva substituiu uma galeria provisória de madeira na serra da Mantiqueira (FREITAS, 2011, p. 97). 
Podemos afirmar que o uso do concreto armado como material construtivo na represa de Guarapiranga foi posterior ao túnel da Central do Brasil, mas é concomitante à construção do primeiro edifício de concreto armado no Estado de São Paulo ocorrida por meio da construção, entre 1907 e 1908, da estação ferroviária de Mayrink, na região de Sorocaba e projetada pelo arquiteto Victor Dubugras (1868 - 1933), então professor da Escola Politécnica de São Paulo e contratado da Estrada de Ferro Sorocabana. O nome da estação homenageava o presidente dessa estrada de ferro, cuja importância do entroncamento ferroviário possibilitou o surgimento da cidade de Mairinque (GOLDEMBERG, 2015). O concreto também deixou sua marca na paisagem.

\section{6 - A fotografia como registro dos trabalhos de engenharia}

Mesmo utilizando técnicas consideradas avançadas e eficientes, a construção da represa Guarapiranga apresentou alguns problemas na obra que necessitavam de reparos. Em 1908 surgiram fissuras no solo permitindo com que houvesse vazamentos de água na represa ainda não concluída, tal situação foi ratificada pela Light e a divulgação de imagens fotográficas corroborou o fato, provavelmente ocorrido

[...] por problemas de projeto, ligados à ampliação da altura da barragem e da capacidade de armazenamento, toda a estrutura esteve sob a ameaça de colapso. Em um ponto onde anos antes se situara o leito do rio Guarapiranga, surgiram fissuras e vários vazamentos [...] A represa foi esvaziada para que intervenções emergenciais de reforço da estrutura fossem executadas durante todo o ano.

[...] uma parte erodiu para dentro do lago e outra parte para jusante na lateral da barragem, formando jorros d'água (ARAÚJO; SOLIA, 2014, p. 45 e 64).

$\mathrm{Na}$ imagem (Figura 40) a seguir, lemos na base inferior da foto a legenda da Light: $N^{o} 1095$ - Opening in Loer Slope at Sta. 21+16 as a result of leak under foundation. Sto.Amaro dam Construction 24-5-1908. Ela explicita o problema de vazamento de água na represa e nos dá a dimensão ao relacionar com as representações

humanas e de um cão sentado em seu redor. As pessoas estão observando o desmoronamento ao mesmo tempo em que são focalizadas pela lente do fotógrafo, 
preparada para mostrar o vazamento, consequentemente requerendo uma solução. Percebemos mais uma vez, ao fundo da foto, um poste e sua fiação elétrica.

Esta é uma das pouquíssimas fotos encontradas no arquivo cuja dimensão de sua base é inferior a da lateral, posicionando-a de maneira vertical, se comparada com as demais fotografias do arquivo sobre a Guarapiranga.

Figura 40 - Cópia fotográfica. Construção da represa de Santo Amaro (Guarapiranga). Abertura provocada por vazamento na fundação na barragem, 1908

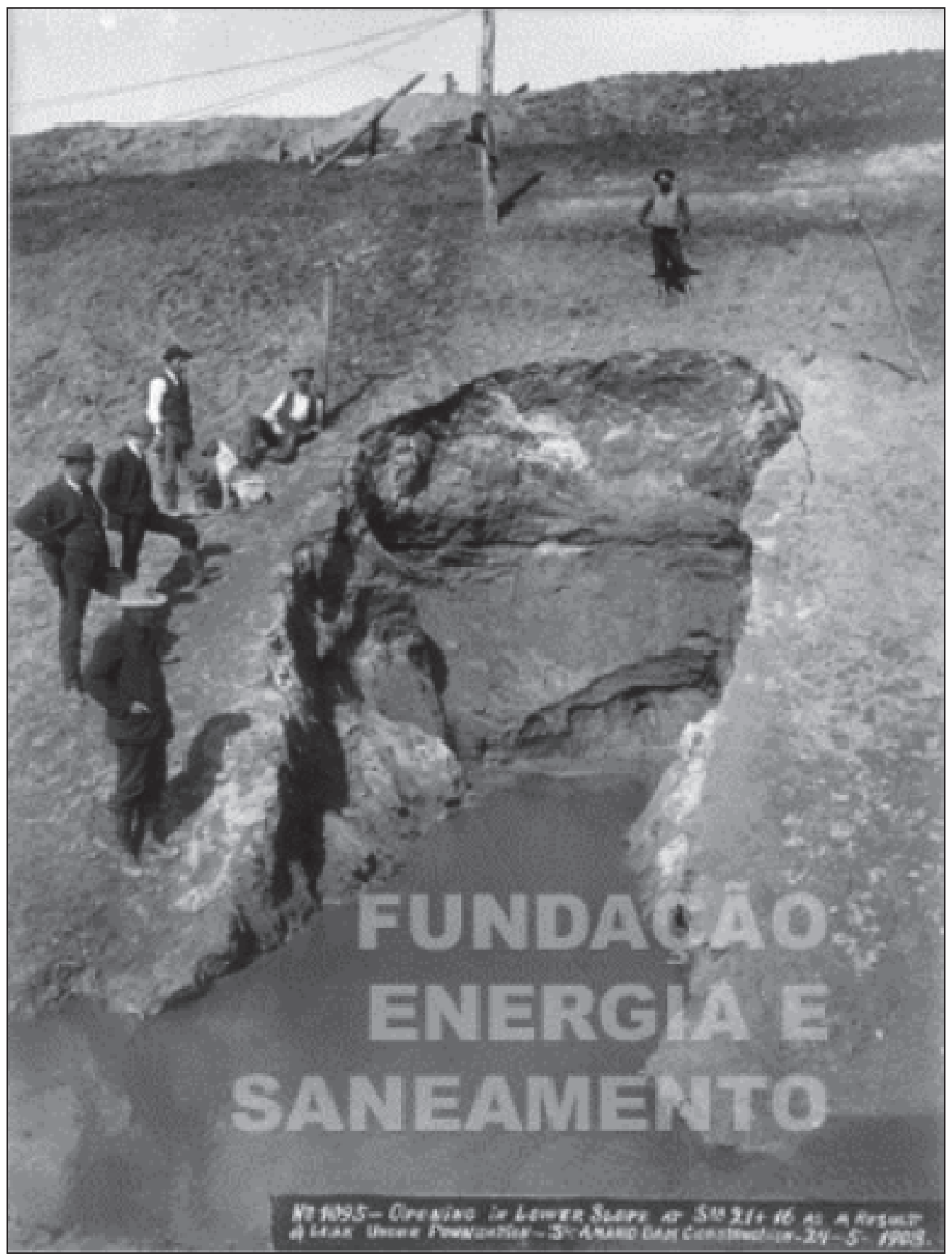

Fonte: Acervo digital da FES (2015). 22,5 x 16,5 cm [ELE.CEI.SAM.001.1095] 
A fissura da barragem da represa agora é vista em outra perspectiva (Figura 41) localizada no talude representado no lado esquerdo da foto com a seguinte legenda da Light: $N^{o} 1096$ - Construction of Enclousure Level at Sta. 21+16 Sto.Amaro. Dam Construction 24 - 5 - 1908. O fotógrafo capturou a imagem destacando em seu centro a formação do empoçamento de água provocado pelo vazamento.

Muitos homens, provavelmente trabalhadores da obra, são visíveis na imagem, além dos cavalos utilizados como meio de transporte e força em atividades da construção. Conforme relatado, a quantidade de trabalhadores era grande, cerca de 300 homens, segundo artigo do Grêmio Politécnico (GREMIO POLYTECHNICO, 1908, p. 142).

Figura 41 - Cópia fotográfica. Construção da represa de Santo Amaro (Guarapiranga). Construção de caixa de contenção para sanar o vazamento, 1908

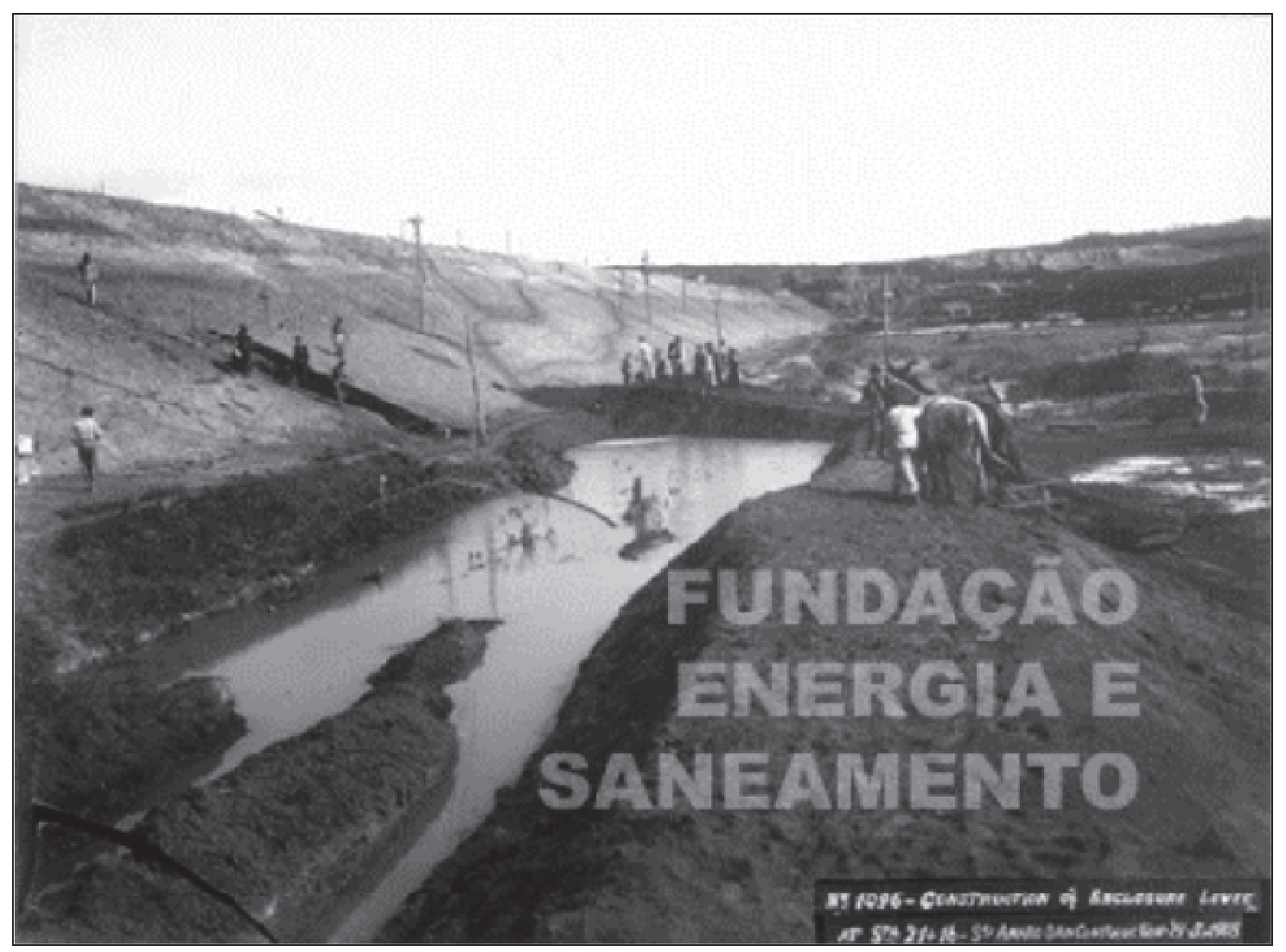

Fonte: Acervo digital da FES (2015). 16,5 x 22,5 cm [ELE.CEI.SAM.001.1096]

O uso de imagens fotográficas sequenciais de fatos ocorridos e da obra como um todo foi observado no acervo da FES. Havia a preocupação da Light em registrar os seus feitos, como nas cópias fotográficas catalogadas em sequência e capturadas pelo 
fotógrafo com aproximações diferenciadas que alteram a escala de observação de uma mesma ocorrência (Figura 42).

Figura 42 - Cópias fotográficas. Construção da represa de Santo Amaro (Guarapiranga). Vazamento na fundação, 1908

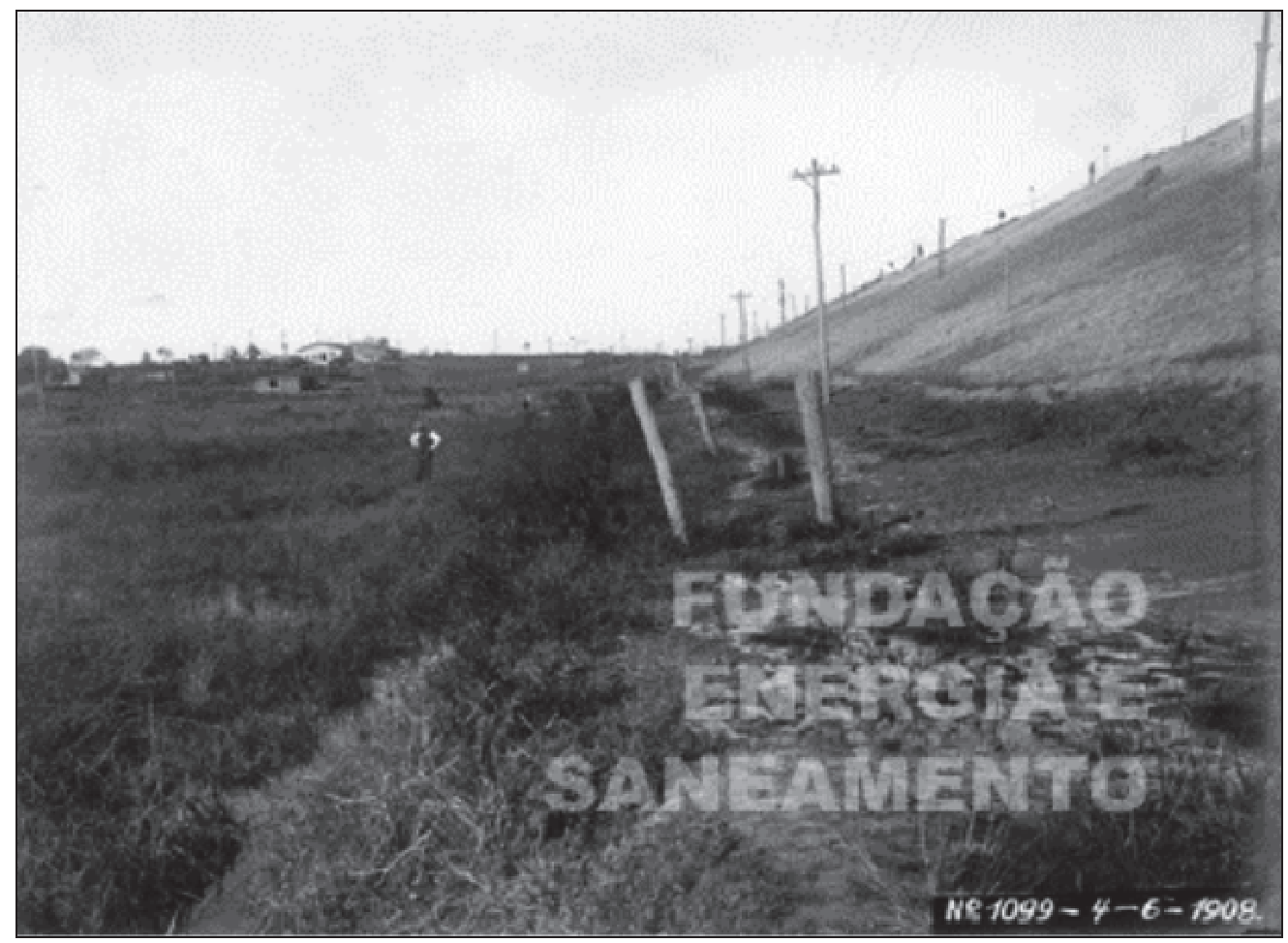

Fonte: Acervo digital da FES (2015). 16,5 x 22,5 cm [ELE.CEI.SAM.001.1099]

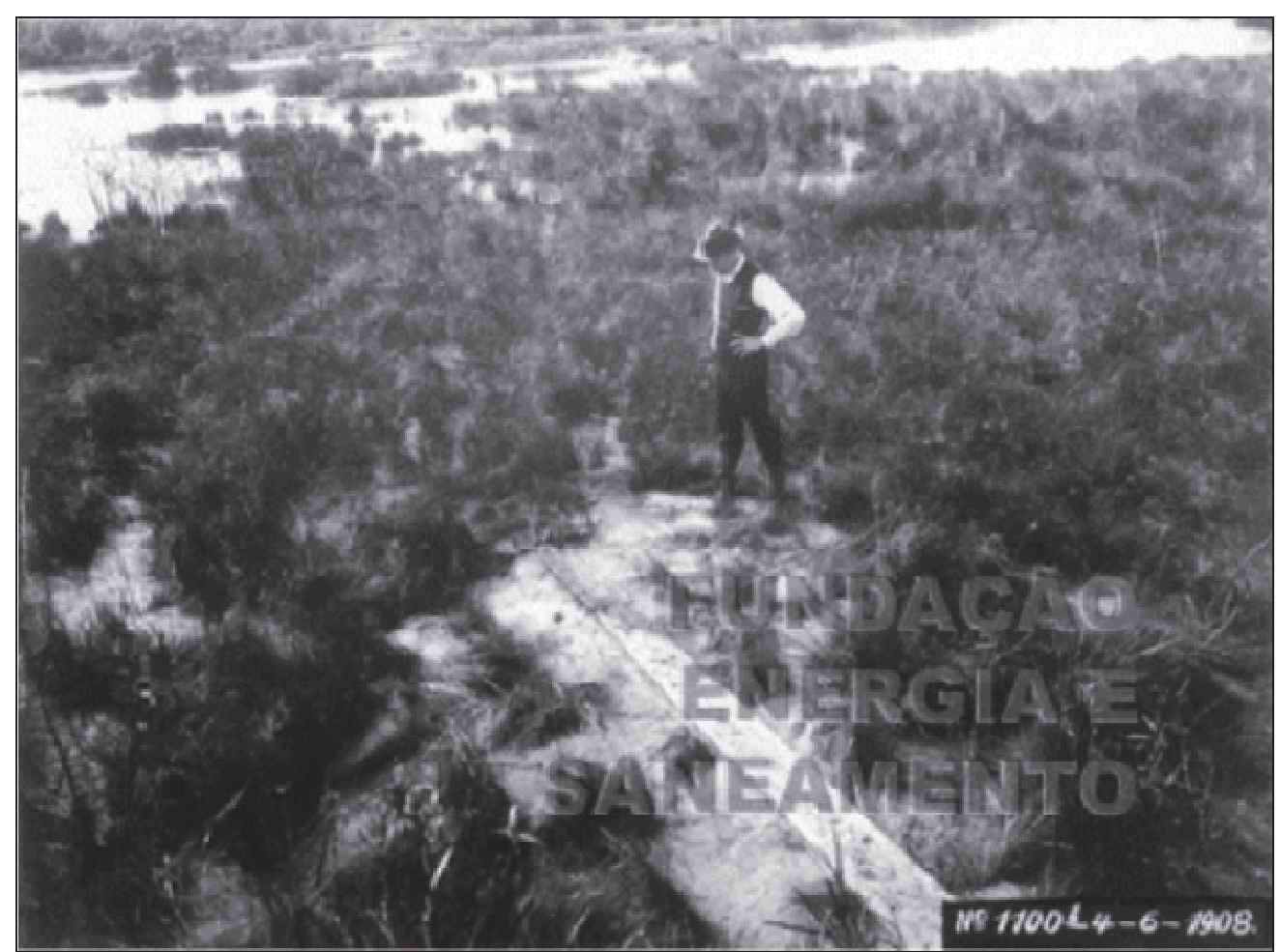

Fonte: Acervo digital da FES (2015). 16,5 x 22,5 cm [ELE.CEI.SAM.001.1100] 
Primeiramente, (Figura 42), com a legenda original: $N^{o} 1099$ - 4- 6- 1908, há uma tomada por parte do fotógrafo na figura do engenheiro à jusante da barragem de maneira distanciada, em meio a vegetação turfosa da região e com o talude da represa à direita, representado de forma longitudinal ao longo de toda a representação imagética. O homem serve também de escala na comparação com a obra, tendo a sua camisa clara realçada com o fundo mais escuro da vegetação que o envolve, permitindo-nos notar suas mãos levadas à cintura e a observar o problema do vazamento d'água da represa aflorando do solo e encharcando-o, no qual é dirigido o seu olhar. Ao fundo, do lado esquerdo da foto, observamos pequenas construções e algumas árvores de maior porte.

$\mathrm{Na}$ imagem seguinte o fotógrafo aproxima a sua tomada de visão e altera a escala de observação que foi produzida a partir de uma posição acima do objeto observado e realça a ideia de um engenheiro com ar pensativo e racional para a questão a ser resolvida. Nesta imagem observamos mais claramente as suas mãos na cintura, a cabeça baixa com o olhar fixo no suposto afloramento de água e uma ripa de madeira em meio à vegetação na área encharcada pelo vazamento. Tal perspectiva leva ao espectador a impressão da formação de um pensamento articulador do engenheiro, entre o problema apresentado e a solução a ser obtida. A solução encontrada foi o reforço da região porosa até a camada impermeável do solo por meio de cravação de estacasprancha, conforme Araujo e Solia (2014, p. 64), a partir do relatório anual da Light para o ano de 1908 e legenda fotográfica original da empresa: $N^{\circ} 1100$ - 4 - 6 - 1908.

As imagens narram uma história e uma intencionalidade na sua produção discursiva. São documentos da análise da paisagem transformada pelas técnicas no espaço geográfico. 
Figura 43 - Composição de cópias fotográficas. Construção da represa Guarapiranga, 1907
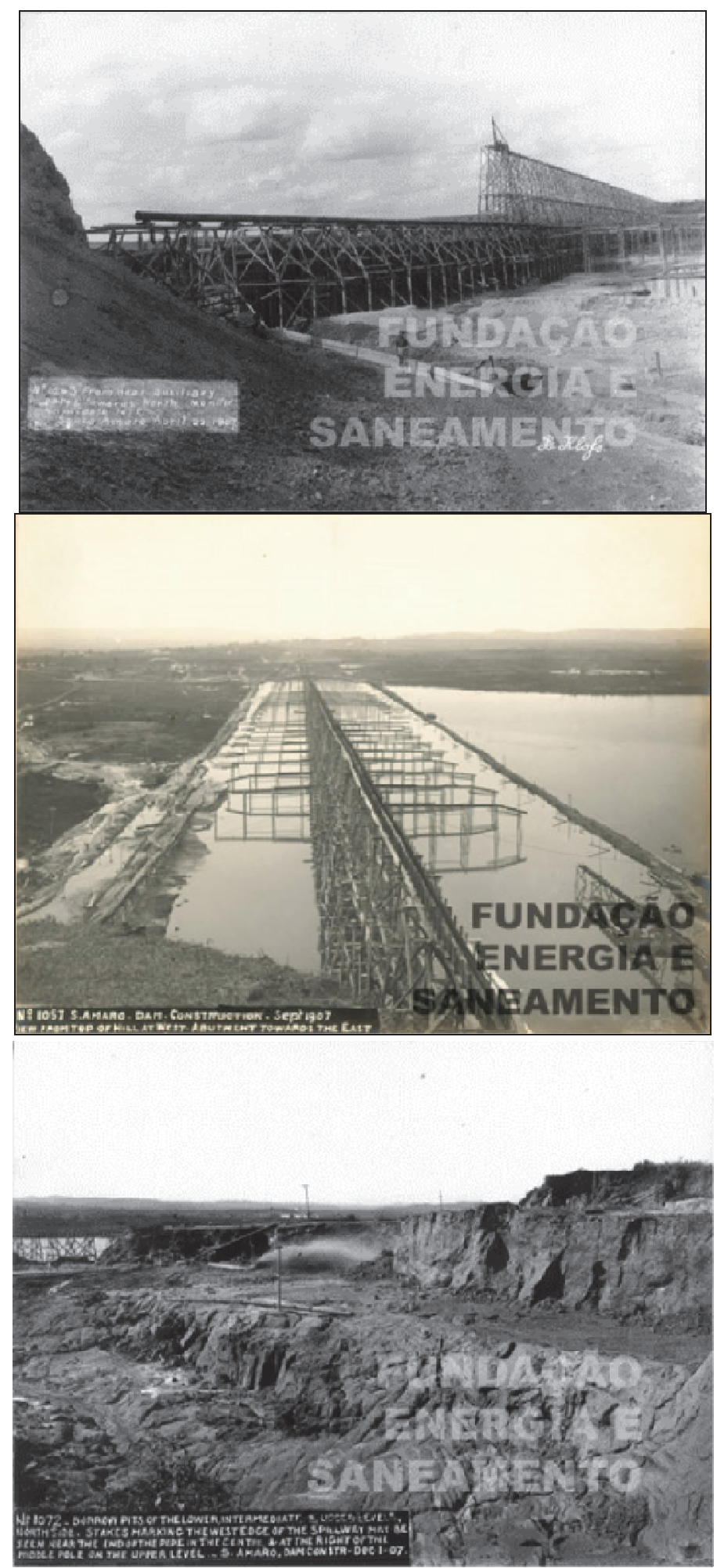

Fonte: Acervo digital da FES (2015). Diagramação do autor (2018). 
A visualização por meio da produção de imagens, quer por desenhos técnicos ou por principalmente fotografias, permite uma contemplação da grandiosidade das estruturas da obra em relação à figura humana e servia para redimensionar a percepção da atuação da Light no território por meio das técnicas de engenharia, além de projetar um cenário futuro a partir de uma imagem presente.

Conforme Chartier (2002, p. 20), a representação imagética é "instrumento de um conhecimento mediado que faz ver um objeto ausente através da sua substituição por uma 'imagem' capaz de o reconstituir em memória e o de figurar tal como ele é”.

Assim, a iconografia associa-se ao discurso do conhecimento produzido pelo progresso científico e cuja modernização de técnicas implantadas no território era usada pela Light a fim de também garantir a simpatia da população e compensar as reclamações e descontentamentos daqueles que rivalizavam com a empresa em questões de indenização das desapropriações, da falta ou do acesso precário à energia elétrica e de outros serviços urbanos da companhia.

A Light, em uma das suas manobras políticas, aproximou-se da maior instituição científica do Estado no que se refere à engenharia, a recém-criada Escola Politécnica de São Paulo, que havia sido fundada em 1893 e com os seus cursos de engenharia iniciados em 1894. A Light pretendia com isso assegurar o reconhecimento de suas ações no território respaldando no conhecimento produzido pela instituição.

O ensino institucionalizado transforma-se em atividade tecnológica voltada para a aplicação de conhecimentos científicos na construção de diversas obras, fato importante para a atuação da Light, cuja aproximação com a Escola Politécnica foi promovida por Robert C. Brown, engenheiro idealizador da Light, e James Mitchell, representante no Brasil da General Electric e proprietário da maior casa de materiais do ramo em São Paulo, a Casa James Mitchell. O objetivo dessa aproximação era atrair os engenheiros formados e obter o apoio da Politécnica nos projetos da companhia, na qual a Escola, em diversos momentos, esteve ao lado da Light, seja para chancelar seus interesses em casos de iluminação pública ou de apoiar a construção da represa de Guarapiranga, através de artigos de seus professores publicados nos jornais, dando respaldo científico aos seus intentos e difundindo a nova tecnologia (SÁVIO, 2015, p. 132,210 e 211).

Destarte, a Escola era para São Paulo não apenas um centro de estudos, mas também uma das formadoras da mentalidade política do quadro que compunha o 
Partido Republicano Paulista, além do mais, parte significativa dos alunos da Politécnica eram os filhos da elite cafeeira que mais tarde seriam membros do Partido, tornando-se importantes agentes da vida pública nacional.

Quanto ao papel da Casa James Mitchell, era o de "[...] gerar demanda para o consumo de energia elétrica, ou seja, criar um movimento na sociedade paulistana que fosse capaz de transformar a eletricidade num elemento corriqueiro no cotidiano do município" (SÁVIO, 2005, p. 211).

É nesse processo de qualificação territorial que as obras da Light foram decisivas e contavam com a participação da Escola Politécnica e da Casa James Mitchell:

A primeira forneceu o seu discurso científico como salvaguarda para a adoção da nova tecnologia, a segunda ofereceu os equipamentos e incentivou o uso de produtos que utilizassem a eletricidade como força motriz (SÁVIO, 2005, p. 212).

As escolas de engenharia utilizavam imagens de desenhos técnicos sobre a construção civil de reservatórios e muitos dos artigos que compunham a então Revista Polytechnica (criada em 1904) continham textos sobre a construção de muros para o represamento de água, como observado na imagem a seguir (Figura 44). Sobre a construção de tais muros destinados ao represamento de rios e aos estudos sobre as estabilidades frente ao empuxo das águas e o empuxo de terras, estes serviam para a produção de conhecimento e para a resolução de problemas que poderiam surgir nas construções de barragens. 
Figura 44 - Desenho técnico. Demonstração de princípio para servir de base à resolução de problema do empuxo de terras nas represas ${ }^{44}$

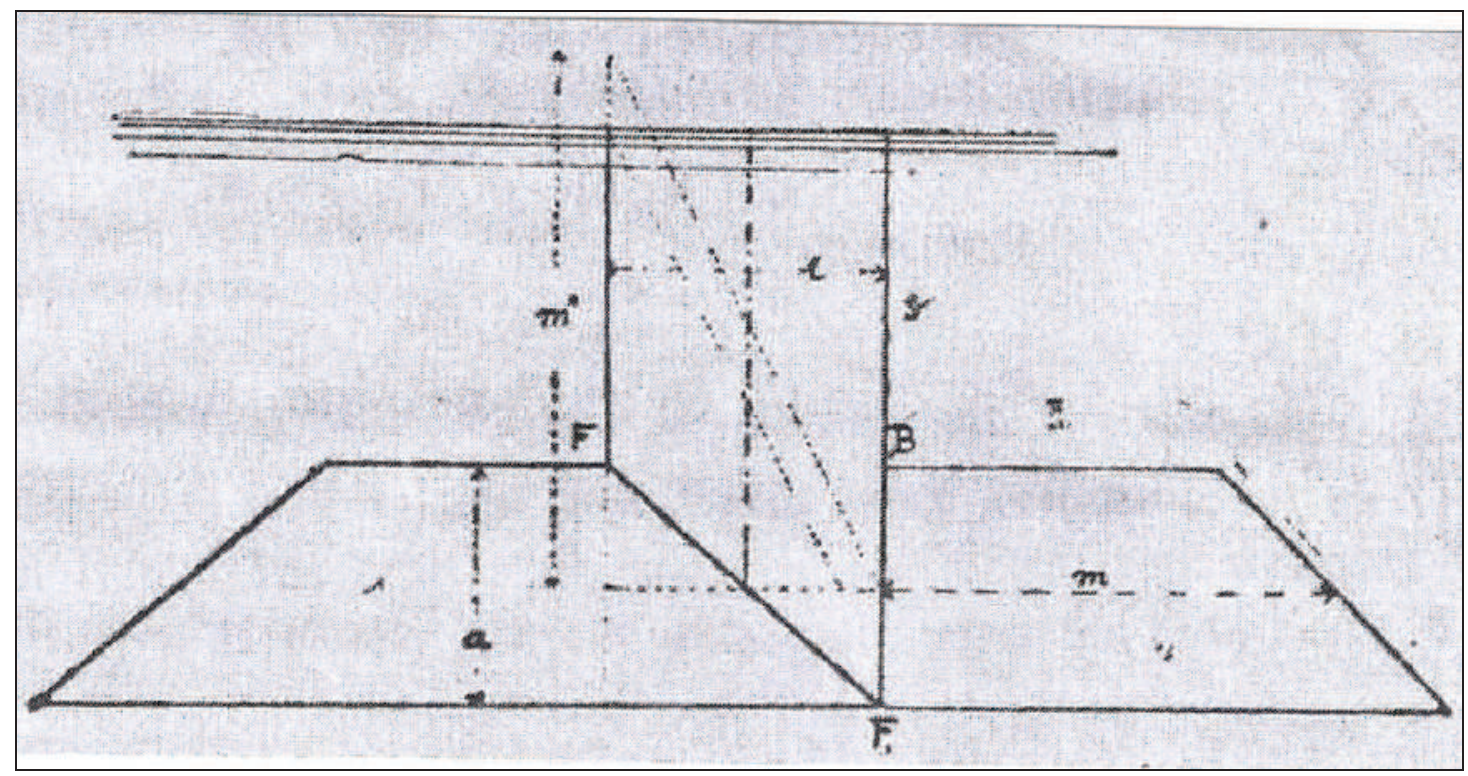

Fonte: Albuquerque (1905, p. 148).

Aliada à imagem do desenho técnico temos a exposição de texto redigido e de fórmulas matemáticas de maneira a explicar e compor o artigo produzido pelo engenheiro, como no fragmento textual reproduzido:

Appliquemos esse ultimo principio demonstrado ao calculo de um muro de reservatorio. Estando o reservatorio cheio, o muro recebe o empuxo da agua de um lado e da terra do outro. Estando vasio, supporta apenas o empuxo das terras. Teremos confiança na construcção se as condições de estabilidade forem preenchidas separadamente para aquelles dois empuxos (ALBUQUERQUE, 1905, p. 148, grafia original).

O desenho técnico é um código básico conceitual das atividades dos engenheiros e não pode ser prescindido, mesmo que outras formas visuais apareçam incorporadas ao seu universo cultural e profissional. As imagens sempre estiveram atreladas ao trabalho de engenharia e

no século XVIII havia a formação na tradição francesa do desenho técnico muito solicitado por instituições cientificas, mas a partir do século XIX há uma preocupação por parte dos engenheiros em documentar por fotografia o seu saber-fazer,

\footnotetext{
${ }^{44}$ Empuxo de terra é a ação horizontal produzida pelo solo sobre as obras em contato com ele.
} 
mostrando as etapas de uma obra. A utilização da fotografia, portanto, embora não tenha substituído o desenho técnico do engenheiro na concepção, detalhamento e ilustração do seu oficio, acrescentou-lhe novas e imensas possibilidades ao incorporar as características da imagem fotográfica e suas potencialidades intrínsecas às atividades de observação, documentação e memória (TURAZZI, 1997, p. 103).

Uma das utilidades da fotografia para os engenheiros era facilitar a fiscalização das obras, resolver conflitos de interesses entre acionista e o governo e promover um trabalho construtivo ou uma companhia, além de divulgar a ciência e a tecnologia, incluindo a sua formação e atuação, sobretudo no decorrer no século XIX com a institucionalização da educação formal dos engenheiros em várias partes do globo e as publicações técnico-científicas que se utilizavam de imagens fotográficas, ampliando e facilitando as formas de intercâmbio profissional (TURAZZI, 1997, p. 104).

Nesse sentido as publicações das revistas especializadas eram muito importantes na produção e divulgação do conhecimento técnico. Como em outro artigo da Revista Polytechnica, intitulado "As forças hydraulicas do Estado de S. Paulo", de 1907, assinado por Guilherme Wendel, engenheiro da CGG de SP, no qual deparamo-nos com a urgência das indústrias em obter força motriz barata e de fácil aplicação para movimentar as suas máquinas. $\mathrm{O}$ texto traz referências aos grandes centros industriais da Europa e as suas localizações em distritos carboníferos, salientando que após o esgotamento do carvão essas indústrias deveriam se alocar para outros lugares onde houvesse um aproveitamento energético de mais fácil aproveitamento e salientava que a maneira mais simples encontrada na natureza é a utilização da força hidráulica por meio das quedas d'água dos rios (WENDEL, 1907).

Para aquele momento histórico, a produção de hidroeletricidade representava algo mais vantajoso e inovador, em relação à utilização da queima do carvão. O autor nos informa que o uso da força hidráulica já estava começando a ser utilizada em muitas regiões montanhosas da Europa, por meio de companhias privadas, citando como exemplo uma queda d'água de quinhentos metros de altura na Noruega.

Destarte, o aproveitamento em grande escala das águas como fonte de energia, segundo o relato do engenheiro, encontrava-se especialmente nos Estados Unidos. O autor aproveita e faz associações às instalações da Light no rio Tietê, porém sem 
nenhuma referência específica à represa Guarapiranga ou a usina de Parnaíba, fazendo apenas citações das quedas d'água de porte considerável do rio no Estado São Paulo.

Em uma analogia às construções de estradas de ferro, é sugerido as suas instalações nas proximidades dos rios com potenciais hidráulicos, a fim de favorecer a industrialização, como observamos no artigo da Revista Polytechnica, de 1907, intitulado "Viação ferrea" e assinado pelo engenheiro Augusto C. da Silva Telles. O artigo traz referências à importância das estradas de ferro para a circulação de pessoas, ideias e mercadorias, permitindo uma associação ao desenvolvimento humano e ao progresso material de uma localidade a ser favorecida economicamente por tais instalações, além de permitir observar as ideias elitistas da época. Em suas palavras, as ferrovias promoviam

facilidade e rapidez na transmissão do pensamento, na locomoção do homem, no transporte de mercadoria, eis o poderoso factor do progresso moderno, da civilisação contemporânea, - eis o grande vehiculo que conduz os povos para a grande arena do futuro.

O movimento é accelerado e aquelles que se descuidarem de acompanhar essa marcha, ou definharão, esquecidos e abandonados em meio da jornada, ou terão a sorte de serem absorvidos e arrastados por alheio esforço, que saberá tirar o proveito das riquezas em potencial inaproveitadas por inércia e inaptidão (TELLES, 1907, p. 287).

No início do século XX ocorre uma profunda tecnização do espaço que conduz em seu bojo a aceleração dos movimentos dos modos de produção e de circulação, movimentos esses já conferidos desde fins do século XIX onde as academias, neste caso representadas pela Revista Polytechnica, encarnaram o papel da divulgação científica, mas principalmente o caráter político das instituições de ciências. A Revista Polytechnica representou, nos dizeres de Sávio (2016),

muito mais do que um espaço para apresentação e debates sobre querelas científicas e interpretações sobre o mundo natural, a divulgação científica teria como principal objetivo validar a existência das instituições de ciência e garantir a sua aceitação pela sociedade. Fundada no ano de 1904 pelos alunos da instituição [...] representou a vanguarda da divulgação científica no estado de São Paulo nas primeiras décadas do século XX (SÁVIO, 2016, p. 60). 
Nota-se que a Revista foi fundada dois anos antes do início das obras da Guarapiranga e continha em seus escritos referências às construções de represas e sua importância para o progresso e transformação urbana.

As novas formas de aproveitamento energético das fontes naturais a serem exploradas traziam a alteração do espaço geográfico e tinham como aliadas as instituições científicas, como a Escola Politécnica de São Paulo, em respaldar as intervenções técnicas em muito dos seus artigos publicados na Revista Polytechnica endossados por seus professores e alunos proeminentes.

Vale salientar a importância do poder público em avalizar todas as ações em torno do território e de fomentar a criação e manutenção de institutos de pesquisa que contribuíam para a divulgação dos projetos que tinham à frente grandes corporações de ordem privada, às quais, aliavam-se às forças políticas preponderantes a fim de que as apoiassem em seus intentos, valendo-se, dentre outros, do discurso científico respaldado na produção de textos acerca do processo de dominação da natureza pela razão humana.

As imagens fotográficas associadas ao progresso no procedimento de conquista dos elementos naturais do território foram muito importantes para criar outra imagem: a da configuração de São Paulo e de seus agentes na primazia da condução das políticas nacionais, uma vez que o regionalismo imperava e os personagens políticos de São Paulo tomavam decisões com essa convicção (LOVE, 1982). Soma-se a esse determinismo científico e ao regionalismo às ações técnicas desenvolvidas nas práticas de grandes empresas privadas, como a Light.

A associação entre as imagens fotográficas e o discurso que se pretendia criar favoreceu a Light desde o início da sua atuação no Brasil, por meio da apresentação das imagens das obras na Cachoeira do Inferno, em Parnaíba, produzidas para relatar os feitos da empresa na produção de energia elétrica, tal observação é corroborada com as informações de Sávio (2015) sobre as narrativas imagéticas promovidas pela Light.

Muitas semelhanças são observadas entre a construção da primeira barragem, em Parnaíba, e a construção da Guarapiranga, quanto ao estudo e promoção por parte da Light e a atuação dos engenheiros da Politécnica em seus discursos sobre as obras, embora as informações sobre Guarapiranga são mais restritas.

As fotografias dos engenheiros concentravam-se nos levantamentos informativos dos territórios que, segundo Turazzi (1997), iam sendo 
progressivamente ocupados pelo homem, no processo construtivo das chamadas obras de arte do engenheiro (estruturas metálicas, estradas de ferro, embarcações, portos, aquedutos, etc) e nos desafios tecnológicos que a engenharia ia superando a cada dia e que de certa forma também se colocavam como desafios à própria arte dos fotógrafos (TURAZZI , 1997, p. 130).

Assim foi com o registro da construção da represa Guarapiranga, um contíguo do complexo de Parnaíba, que serviu para o represamento de águas com o intuito de atender e permitir o bom funcionamento da usina rio abaixo, constituindo um suporte necessário, sobretudo em períodos de baixo índice pluviométrico no rio Tietê. Tal suporte constituía um aparato da engenharia no território e suas representações eram divulgadas em imagens técnicas pela Light em seus relatórios e publicidade, como o registrado na planta geral dos aproveitamentos hidroelétricos e no perfil esquemático do represamento das águas e o seu deslocamento para a produção de energia nas usinas hidrelétricas da companhia (Figura 45).

Nessa planta apresentada em fins da década de 1940 notamos o crescimento da mancha urbana e a assimilação de Santo Amaro pela Capital, onde as águas da represa Guarapiranga encontram-se ao sul juntamente com a urbe, no constante processo de crescimento urbano. $\mathrm{Na}$ representação percebemos, ainda, os outros represamentos promovidos pela Light na região, suas usinas geradoras de energia, as linhas de transmissão elétrica, as estradas de ferro e de rodagem, tudo em uma base cartográfica com realce na hidrografia.

Para a produção elétrica, por meio das águas, a forma mais usual de armazenamento de energia é interromper o curso de um rio e criar barragens, permitindo o deslocamento da água do alto para baixo, movimentando turbinas, que por sua vez operam geradores de corrente elétrica por indução magnética. A eficiência energética desse sistema é alta, além de ser uma fonte de energia renovável e apresentar outras possibilidades de usos, como o controle de enchentes, irrigação, abastecimento de água, piscicultura e turismo. Aqui, a construção da represa Guarapiranga visava a atender o interesse da Light centrado na produção de energia elétrica.

No início do século XX, no Brasil, a lenha era ainda muito utilizada e a grande parte do carvão era obtida em uma antiga sistemática de derrubada de florestas sem o correspondente replantio. As pioneiras metalúrgicas de pequeno porte, concentradas nos 
campos auríferos de Minas Gerais, desde o século XIX utilizavam lenha em usinas constituídas com recursos governamentais e com a reserva de florestas para seu uso (MARANHÃO; MATEOS, 2012, p. 13). 
Figura 45 - Planta geral do aproveitamento hidroelétrico da Light nas mediações da cidade de São Paulo.

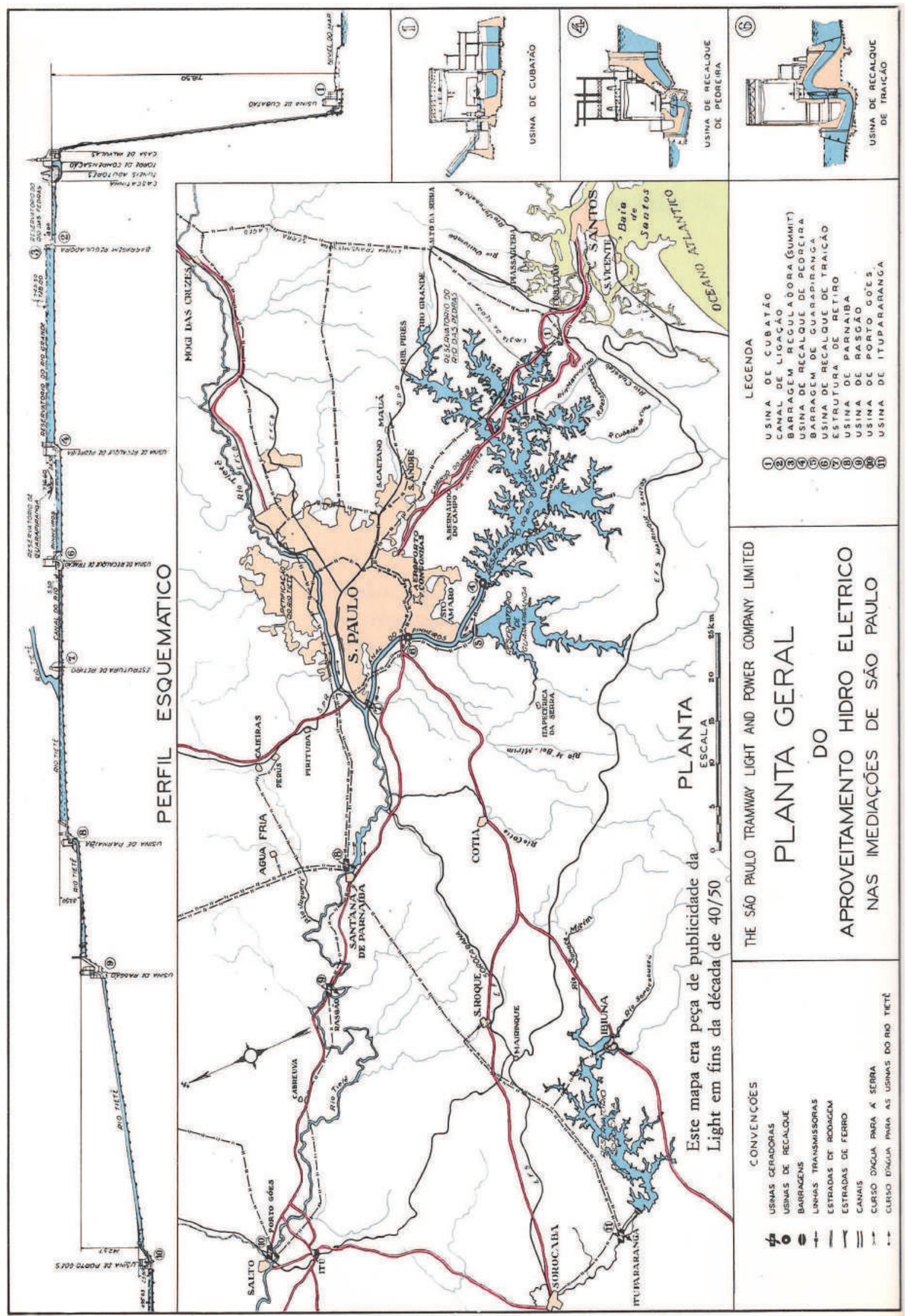

Fonte: Souza (1982, p. 104). 
Em uma abordagem detalhada da representação visualizamos o esquema de orientação das águas da represa Guarapiranga até a Usina de Parnaíba, deslocando-se da barragem em Santo Amaro para o rio Pinheiros até atingir o rio Tietê e seguindo seu percurso rio abaixo até Parnaíba (Figura 46).

Figura 46: Detalhe da Planta geral do aproveitamento hidroelétrico da Light no trajeto

Represa Guarapiranga - Santana de Parnaíba. c.d. 1940. Escala aproximada 1:700.000

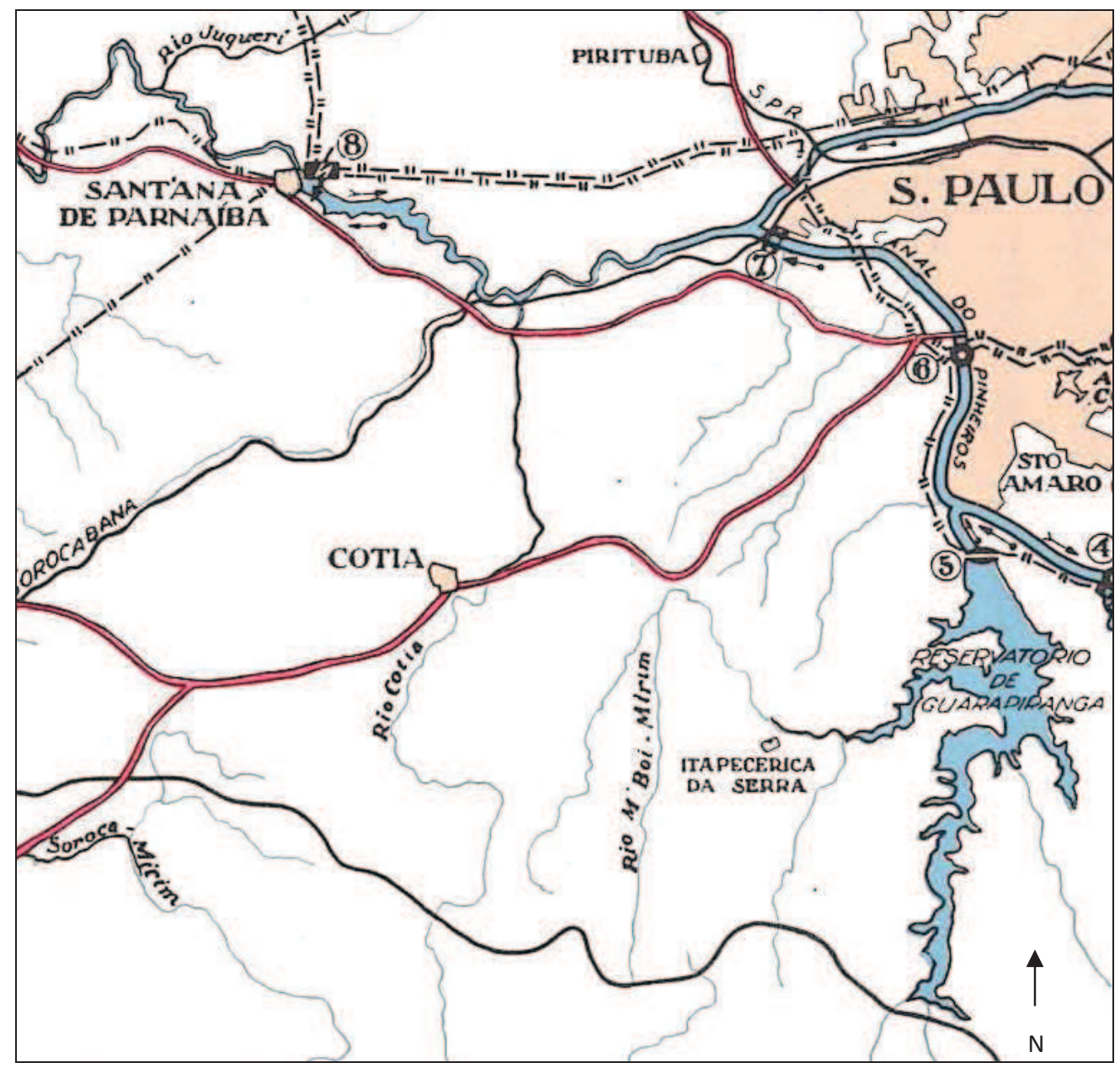

Fonte: Souza (1982, p. 104). Adaptação do autor (2018).

As comparações entre as grandes construções de um mesmo período, seus registros fotográficos, a atuação e formação dos engenheiros, além dos interesses econômicos da companhia que articulava com os interesses estatais, são essenciais para descortinarmos a atuação da Light que contava com favorecimentos em virtude das suas relações políticas, do respaldo dado pelos engenheiros da Politécnica às obras e das imagens produzidas sobre as intervenções que promovia no meio físico, alterando e compondo uma nova paisagem no território. 
A ação da Light foi decisiva no sentido de prover em São Paulo a eletricidade em larga escala e propiciar uma industrialização mais fecunda em seu território, permitindo-a configurar sobremaneira a transformação espacial por meio dos seus empreendimentos e relações políticas que visavam a atender seus interesses. Segundo Sevcenko (1992),

a Light, naturalmente, era a peça decisiva no modo de expansão da cidade. Localizando as paradas finais de suas linhas em pontos extremos e de população rarefeita [...], ela gerou fluxos irradiados de valorização imobiliária que, seguindo as direções de seus trilhos, suscitavam a criação de loteamentos em áreas remotas. Essas áreas, ao obterem os serviços básicos de transporte, eletrificação e gás, fornecidos pela própria Light, geravam zonas intermediárias entre esses locais já dotados de infraestrutura e o centro da cidade, tornadas automaticamente supervalorizadas, o que elevava os preços dos terrenos e alugueis em níveis exponenciais. $\mathrm{O}$ resultado dessa prática sistemática era o surgimento de bairros inteiros completamente desconectados, além da escassez drástica de praças, espaços públicos e amenidades (SEVCENKO, 1992, p. 123-124).

Assim, tanto a Light como as elites político-econômicas tendiam, segundo Rolnik (1997 apud SÁVIO, 2015, p. 133), a

[...] desprezarem a população da cidade [de São Paulo] e desejarem apenas um modelo de modernidade para a chamada boa sociedade, o que é refletido por políticas públicas que acabaram por expulsar a população das regiões mais centrais, aquelas que eram atendidas pelos serviços da empresa [Light], empurrando-as para os subúrbios e as regiões de várzeas.

A empresa ainda impunha e direcionava o fluxo de pessoas nos finais de semana, ofertando mais bondes em uma determinada linha em restrição a outras, conforme Sevcenko (1992, p. 133).

Aliado a esses fatores temos o discurso científico e as obras intervencionistas no território que visavam ao progresso técnico para o desenvolvimento econômico em uma aplicação direcionada e não neutra de seus estrategistas para a região e para a população de um modo geral. Consequentemente, esse comportamento deixava marcas na transformação da paisagem, sendo captadas pelas fotografias de implantação dos suportes técnicos. 
Nas imagens das obras da represa Guarapiranga observamos a relação da divulgação de algumas de suas fotografias entre o acervo da Light e a revista da Politécnica, em uma circularidade de saberes, ideias e registros de seus engenheiros, como demonstrado nas cópias fotográficas a seguir e que se trata de uma mesma imagem (Figura 47) produzida pela Light em 1908 e constante em seu arquivo com a legenda original: $N^{o} 1087$ - View from West End of Dam -Sto. Amaro Dam Construction-31-3-1908, em sua base inferior. Esta imagem também é utilizada na Revista Polytechnica, contudo a foto foi recortada nas bases superior e inferior, suprimindo a legenda e em seu lugar aparece impresso a assinatura da revista: Rev. Polyt., compondo o artigo que trata sobre a construção da Light em Santo Amaro e noticiada pelos engenheiros da Politécnica em sua revista, fazendo parte de um texto pensado para este mesmo público em formação ${ }^{45}$.

$\mathrm{Na}$ imagem o fotógrafo centraliza a construção da barragem em uma tomada de cima para baixo, visualizando a estrutura da obra com uma calha central a levar os sedimentos para formação do talude. Ao fundo vê-se o horizonte de Santo Amaro contrastando a monocromia preto/branco da representação com a obra de formação da represa que, a montante, lado direito da foto, está com as águas se acumulando. À jusante encontramos algumas casas e a representação de solo exposto em alguns locais. Nota-se, no lado esquerdo da foto e de maneira perpendicular a ela, a presença de fios de energia elétrica na condução da força que auxiliava na construção. Algumas embarcações também são notadas nas águas do represamento, lado direito da foto, e serviam de apoio para a obra.

Tanto à montante como à jusante há a presença de homens trabalhando quase imperceptíveis na escala da abordagem fotográfica e em comparação com a grandiosidade da represa em formação. Essa presença humana não é o tema central da perspectiva do autor cuja centralidade está na obra em si e nas técnicas de concepção de um novo espaço ${ }^{46}$.

\footnotetext{
${ }^{45} \mathrm{Na}$ revista pesquisada, todas as páginas com registros fotográficos não são numeradas. A numeração é suprimida, como se a página não existisse. Tal situação assemelhasse aos comentários de Schwarcz (2014), sobre a pouca importância conferida às referências imagéticas. Ao longo de muito tempo consideravam-se as imagens como simples ilustrações, revelando toda a importância tão somente ao texto redigido. As legendas nas cópias fotográficas tampouco aparecem.

${ }^{46}$ As figuras humanas são perceptíveis com clareza no equipamento eletrônico disponível na FES, possibilitando a visualização ampliada em forma digital.
} 
Figura 47 - Cópia fotográfica. Construção da represa de Santo Amaro (Guarapiranga). Vista panorâmica da barragem, 1908

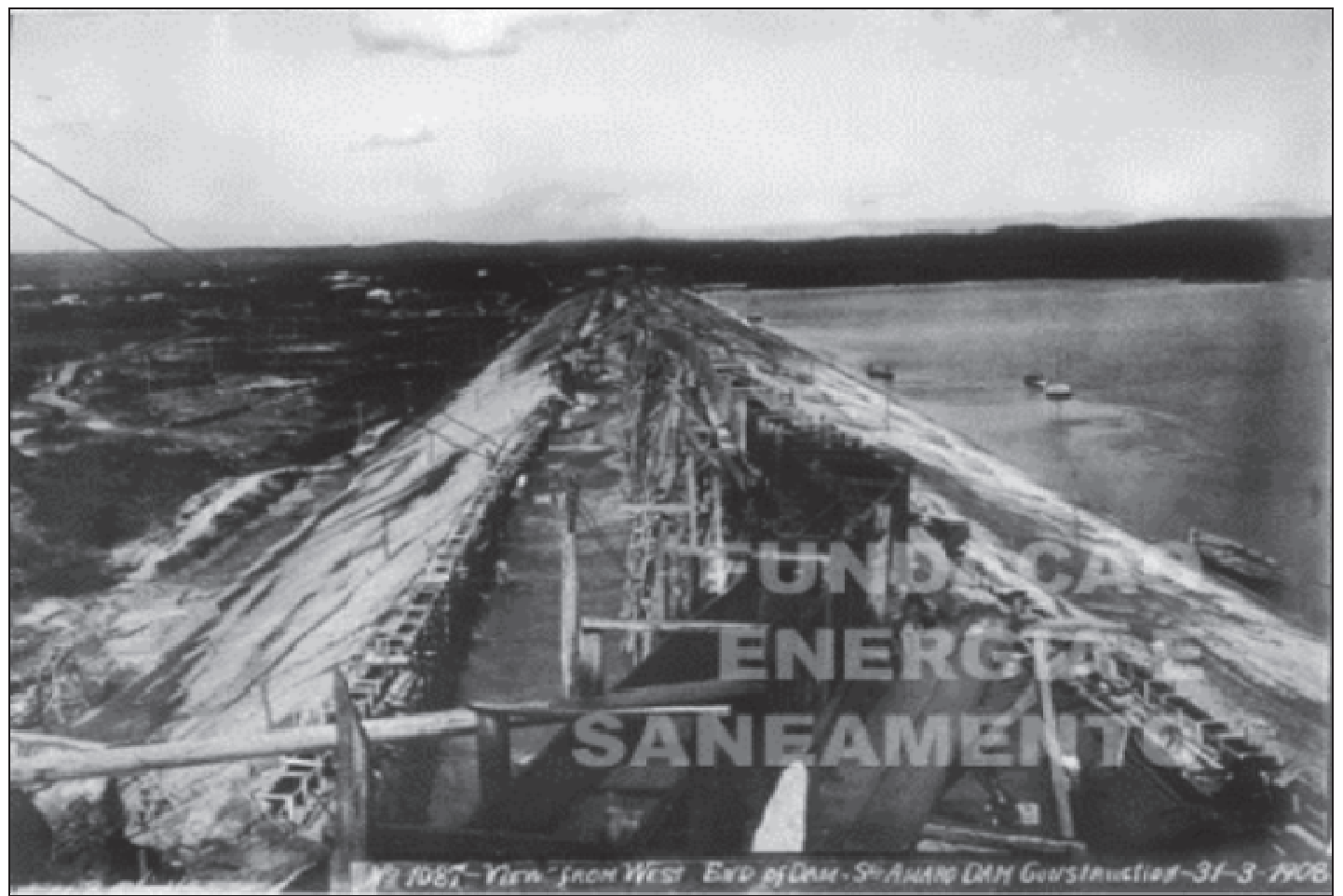

Fonte: Acervo online da FES (2015). 16,5 x 22,5 cm [ELE.CEI.SAM.001.1087]

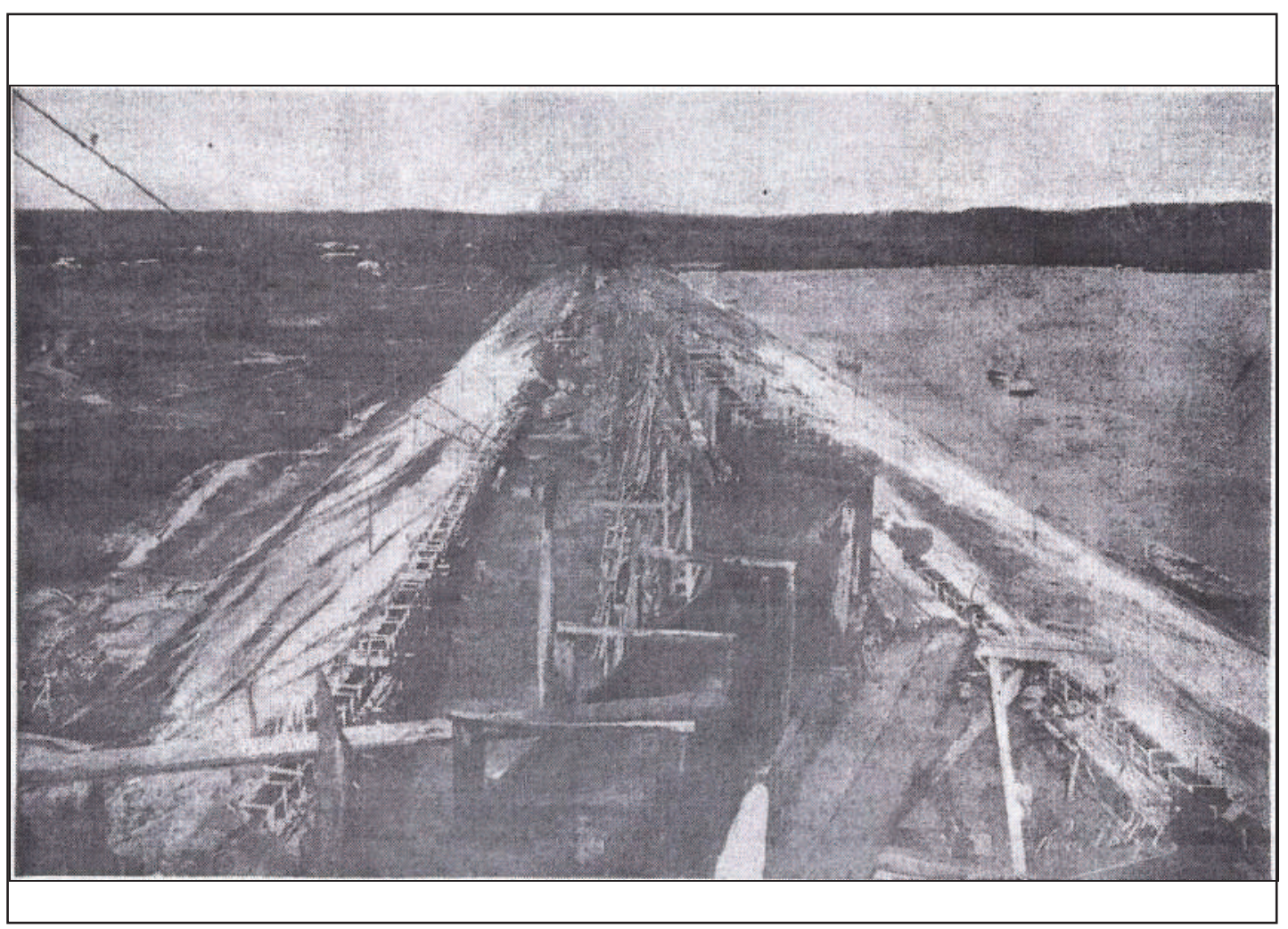

Fonte: Revista Polytechnica, São Paulo, v. 4, n. 21, fig. 4, abr./maio (1908). 
Em outra imagem pesquisada do acervo da FES e pertencente na origem à Light (Figura 48) encontramos esta mesma representação no artigo da Revista Polytechnica, contudo, neste caso, a Revista excluiu a legenda original, From North Side near Sta. 9 [?] towards west. Santo Amaro. April 22.1907, e incluiu a sua marca na base inferior à direita da foto: Rev. Polyt.

Esta legenda foi a única verificada em posição mais distanciada da base inferior da cópia fotográfica em relação às outras imagens do acervo, talvez, por isso, a Revista não tenha feito o recorte na foto. Ela nos remete ao início da construção da barragem possibilitando visualizar as estacas de madeira e as folhas de zinco colocadas de maneira a conter a água na represa. Ao fundo da imagem e no contraste monocromático da representação percebemos parte do horizonte da região com a sua vegetação e o céu como delineador na oposição claro e escuro da representação.

Mais uma vez o fotógrafo captura a imagem centralizando aquilo que é do seu interesse, a grande parede que dará sustentação aos sedimentos a serem ali depositados. A sua representação está de maneira longitudinal na foto a fim de possibilitar a visualização mais completa possível. Ao fundo da foto, imediatamente acima da parede de contenção, observa-se o desmonte hidráulico que permitirá o deslocamento do solo pela água e que formará o talude já analisado em imagens anteriores.

O artigo da Revista Polytechnica, de 1908, apresenta-nos a seguinte orientação:

\section{[...]}

As fundações constaram de simples limpeza, com ligeiro apiloamento [como amassar por pilão], não se tendo encontrado fontes a desviar, e sendo o solo muito firme.

Antes de começar o aterro foi applicada segundo o eixo da barragem, enterrando-se-a até alcançar terreno mais firme, uma parede em folhas de zinco, elevando-se até perto da crista.

Tem esta parede por fim evitar os estragos causados por animaes como tatús, formigas etc. e de que facilmente resultaria a ruína da barragem. Esta utilidade é incontestavel, mas não podemos todavia affirmar que a divisão da barragem em duas partes sem a menor cohesão entre si não será causa de enfraquecimento da construccão

(GREMIO POLYTECHNICO, 1908, p. 140, grafia original). 
Figura 48 - Cópia fotográfica. Construção da represa de Santo Amaro (Guarapiranga), 1907

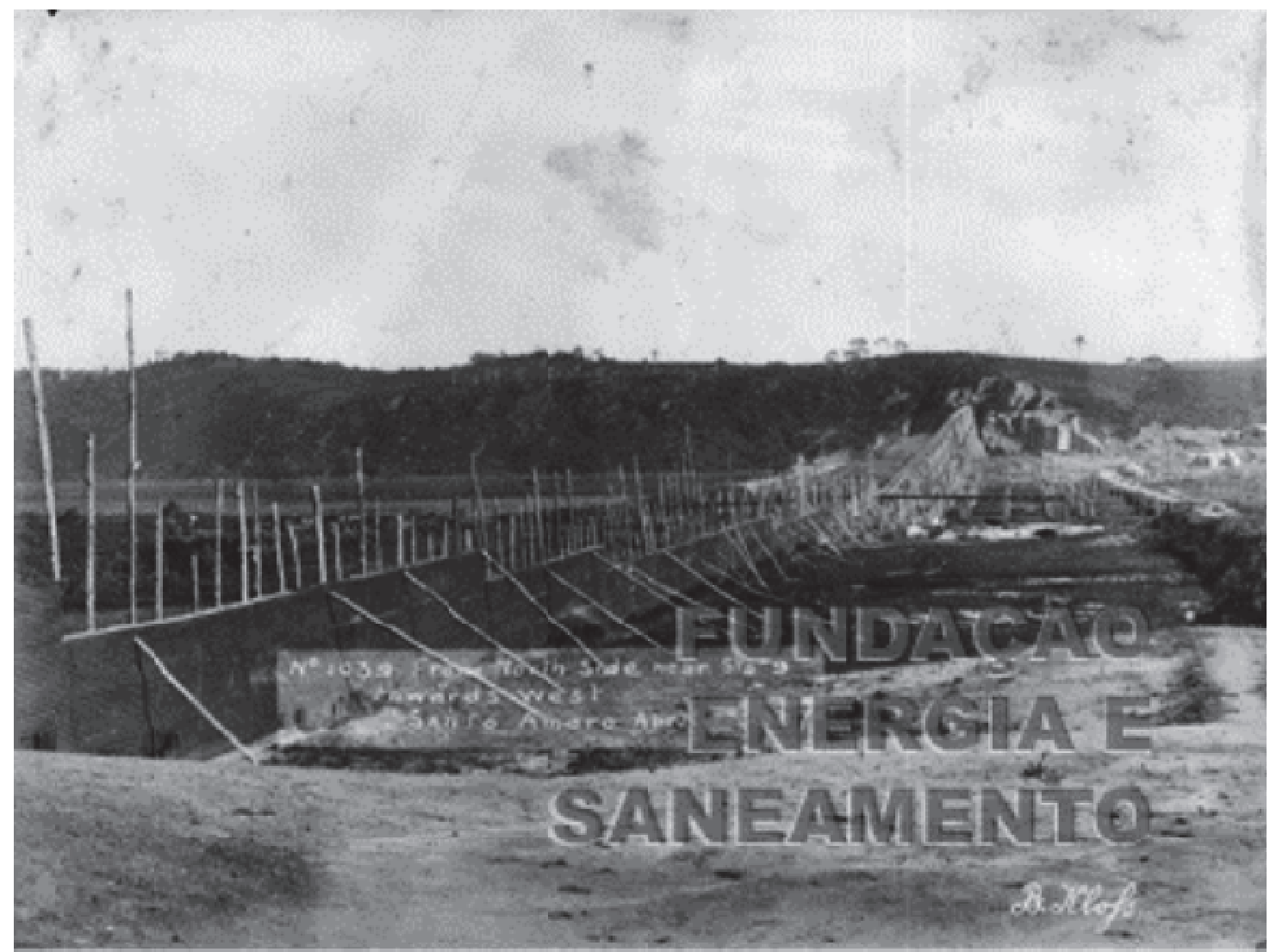

Fonte: Acervo online da FES (2018). 17 x 23 cm [ELE.CEI.SAM.001.1039]

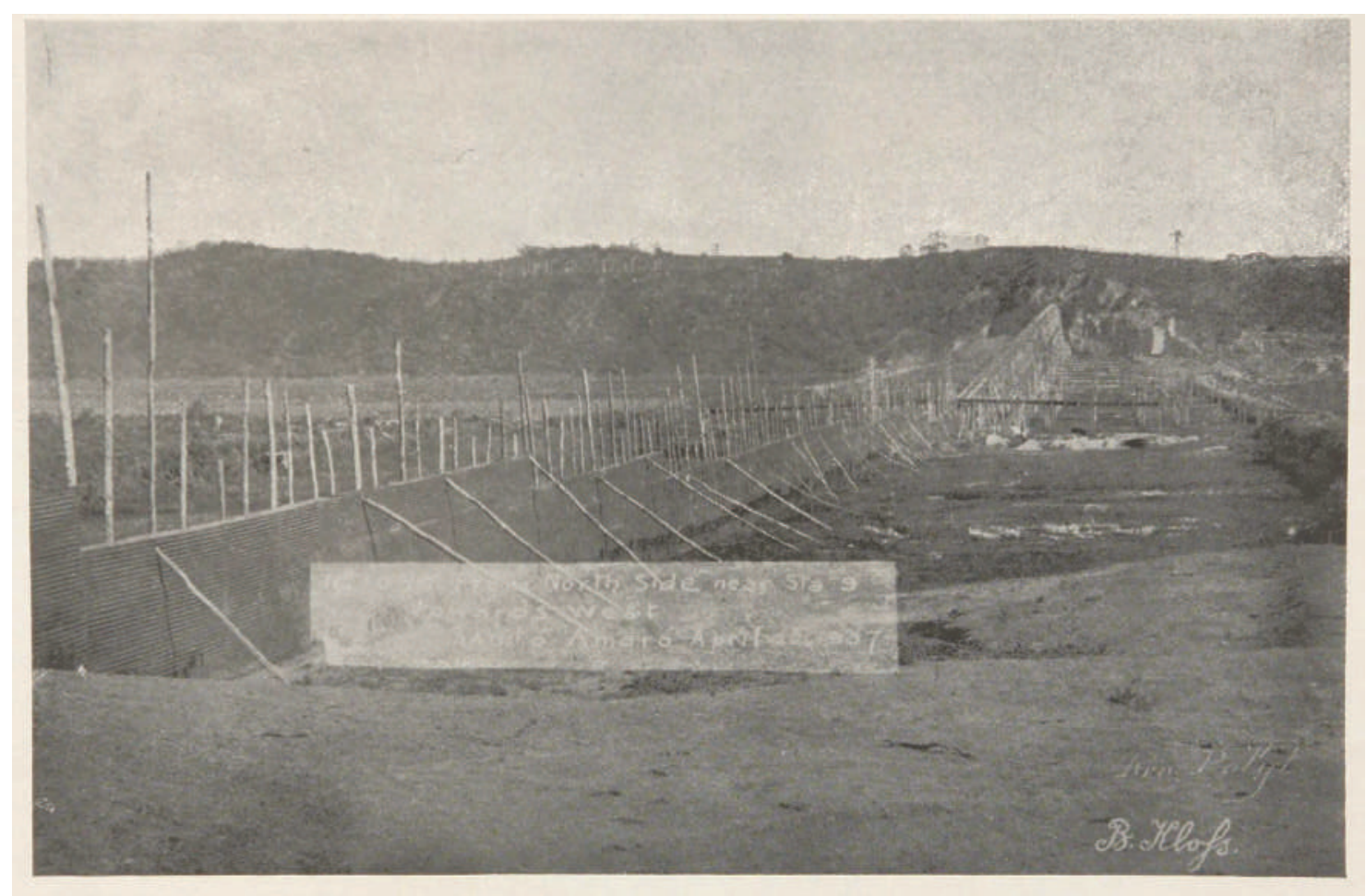

Fonte: Revista Polytechnica, São Paulo, v. 4, n. 21, fig. 2, abr./maio (1908). 
Tal fato, da produção das imagens fotográficas das obras da represa circularem entre os meios técnicos e acadêmicos, denota a importância das obras da Light para o desenvolvimento econômico da região, para o registro e a propaganda da sua atuação na paisagem e na formação de um novo espaço de apropriação avalizadas pelas instituições científicas locais, e ainda, centro de formação política, responsável em parte pelo avanço tecnológico e de inovações.

A sequência de imagens produzidas é um tema em si, representa as etapas da construção em um determinado contexto que foi considerado importante e digno de registro e arquivo. Conforme Turazzi (1997), as sociedades se pensam historicamente com os instrumentos que lhes são próprios em cada momento e a fotografia representa um desses mecanismos na cultura histórica e como parte de um processo de construção de novos documentos, além de ter reforçado os ritmos cada vez mais velozes da sociedade.

As representações fotográficas das obras técnicas de engenharia marcante para o século XIX e para o início do século XX tiveram uma intenção de documentar e preservar para a memória os suportes visuais "das transformações introduzidas pela tecnologia - isto é, pela ciência, arte e oficio do engenheiro" (TURAZZI, 1997, p. 261262).

Em uma leitura transversal com a nossa pesquisa sobre a construção da Guarapiranga e o registro e arquivo das fotografias e escritos sobre a obra, observamos as mesmas condições e preconizações já observadas no final do Império, quanto às questões das técnicas a delinear a transformação espacial no Brasil. 


\section{5 - CONSIDERAÇÕES FINAIS}

O estudo concentrou-se basicamente em dois eixos de análise: um o da transformação da paisagem da região de Santo Amaro, capitaneada pela cidade de São Paulo, com a construção da sua primeira represa em Guarapiranga e todo o processo político, social e econômico no qual estava inserida, destacando o papel das inovações técnicas, por meio da eletricidade, utilizadas por engenheiros na obra e consequentemente na transformação paisagística; o outro é narrar essa história por meio das imagens fotográficas singulares do acervo da FES e voltadas para o registro de documentação, publicidade e memorização feitas pela Light, ao mostrar a construção da represa com a utilização da técnica construtiva do desmonte hidráulico e a atuação dos engenheiros, os quais também contribuíram para uma cultura fotográfica presente na sua formação e atuação com o apoio de instituições científicas, como a Escola Politécnica de São Paulo.

Assim, o trabalho procura demonstrar as relações entre os registros das imagens fotográficas que retratam a represa Guarapiranga, à época da sua formação, e as alterações ocorridas na paisagem, por meio das técnicas e do trabalho de grupos sociais que atuaram no território naquele momento.

Algumas fotografias do acervo digital pesquisado foram expostas nesta pesquisa como fontes de interpretação do espaço transformado pela técnica e pelas diretrizes das decisões de políticas públicas no final do século XIX e início do XX, que tinham no setor privado o grande agente de intervenção no espaço físico, transformando as paisagens de acordo com as propostas urbanísticas, adequação aos novos equipamentos e para melhor servir ao capital em sua fase de implantação industrial.

Percebemos a acelerada urbanização de São Paulo e, em grau menor, de Santo Amaro a partir do início do século $\mathrm{XX}$, sobretudo com o advento da produção e fornecimento de energia elétrica proporcionada pela hidrelétrica de Parnaíba, em que se pese a construção da represa Guarapiranga, um grande reservatório que alterou drasticamente a paisagem local e possibilitou a inserção de São Paulo, dentre vários outros fatores, no chamado mundo moderno, consequentemente alterando as relações da cidade com as demais localidades do globo e transformando-a no centro de gravidade nacional. 
O progresso material e a dispersão por meio da comercialização de energia elétrica e do desenvolvimento dos transportes públicos urbanos mais ágeis, para grandes contingentes populacionais, só foi possível graças ao desenvolvimento de novas tecnologias, aqui entendidas como a associação entre as ciências e as técnicas, e ao novo momento da produção e apropriação capitalista do espaço, aliado à ação de grandes companhias de força e luz.

A exploração da imagem como forma comunicativa e dinamizadora do conhecimento remonta da experiência humana desde os seus primórdios e rendem utilidades para diversas intenções, como a apresentação de uma nova técnica construtiva e a visualização de cenários transformados por essas técnicas; como se pretende relatar na narrativa dos fatos associados aos elementos textuais.

Consideramos as imagens fotográficas pesquisadas de grande valia para o entendimento da constituição da paisagem configurada na dinâmica têmporo-espacial, pois as reproduções estudadas referem-se a cenas recortadas de um espaço físico que se articula, remodela-se e acumula-se nos territórios temporalizados. Nele circunscrevendo as políticas públicas pela atuação dos agentes produtores desse espaço, nas diferentes escalas de ação e com a utilização das técnicas disponíveis no momento de sua ação. 


\section{REFERÊNCIAS}

AB'SÁBER, Aziz Nacib. O sítio urbano de São Paulo. In: AZEVEDO, Aroldo de (org.) A cidade de São Paulo: estudos de geografia urbana. São Paulo: Companhia Editora Nacional, 1958. v. 1: A região de São Paulo. p. 169-245.

AB'SÁBER, Aziz. Os domínios de natureza no Brasil: potencialidades paisagísticas. São Paulo: Ateliê Editorial, 2003.

ALBUQUERQUE, Alexandre. Muros de reservatório. Revista Polytechnica, São Paulo, v. 2, n. 3, p. 145-154, mar. 1905.

ARAÚJO, Ricardo; SOLIA, Mariângela. Guarapiranga 100 anos. São Paulo: Fundação Energia e Saneamento, 2014.

ARAÚJO FILHO, J.R. de. O café, riqueza paulista. São Paulo: Boletim Paulista de Geografia. n. 68. s.d. p. 51-124.

AUMONT, Jacques. A imagem. 11 ${ }^{\text {a }}$ ed. Campinas: Papirus, 2006.

AZEVEDO, Aroldo de. Subúrbios orientais de São Paulo. Tese de concurso à cadeira de Geografia do Brasil da Faculdade de Filosofia, Ciências e Letras da Universidade de São Paulo. São Paulo, 1945.

AZEVEDO, Aroldo de. São Paulo, cidade trimilionária. In: AZEVEDO, Aroldo de (org.) A cidade de São Paulo: estudos de geografia urbana. São Paulo: Companhia Editora Nacional, 1958. v. 1: A região de São Paulo. p. 5-40.

BELluZZO, Ana Maria de Moraes. O Brasil dos viajantes. São Paulo: Metalivros; Salvador: Fundação Emílio Odebrecht, 1994. v. 2: Um lugar no Universo.

BERARDI, Maria Helena Petrillo. Santo Amaro. $2^{a}$ ed. Série História dos Bairros de São Paulo. São Paulo: Prefeitura Municipal de São Paulo, 1981. v. 4.

BOBEK, Hans; SCHMITHÜSEN Josef. A paisagem e o sistema lógico da geografia. In: CORRÊA, Roberto Lobato; ROSENDAHL, Zeny (org.) Paisagem, tempo e cultura. $2^{\text {a }}$ ed. Rio de Janeiro: EdUERJ, 2004. p. 75-83.

BRANCO, Samuel Murgel. Energia e meio ambiente. São Paulo: Moderna, 1990.

BURGI, Sérgio. O paço, a praça e o morro. Rio de Janeiro: Instituto Moreira Salles, 2016.

BURKE, Peter. Testemunha ocular: o uso de imagens como evidência histórica. São Paulo: Editora Unesp, 2017. 
CAMPOS, Cristina de. A cidade salubre e bela: propostas e planos de saneamento para a capital paulista no século XIX. In: JORGE, Janes (org.) Cidades Paulistas: estudos de história ambiental urbana. São Paulo: Alameda, 2015. p. 119-135.

CARVALHO, Rogério Lopes Pinheiro de. Ritmos e impressões: modernidade e cosmopolitismo em São Paulo, 1899-1920. 2003. Dissertação (Mestrado em História Social). Faculdade de Filosofia, Letras e Ciências Humanas, Universidade de São Paulo, São Paulo, 2003.

CASTRO, Celso. Pesquisando em arquivos. Rio de Janeiro: Jorge Zahar, 2008.

CAVENAGHI, AIRTON JOSÉ. Imagens que falam: olhares fotográficos sobre São Paulo (Militão Augusto de Azevedo e "São Paulo Light and Power Co", fins do século XIX e início do século XX). 2000. Dissertação (Mestrado em História Social). Faculdade de Filosofia, Letras e Ciências Humanas, Universidade de São Paulo, São Paulo, 2000.

CHARTIER, Roger. O mundo como representação. São Paulo: IEA, 1991. Disponível em: http://www.revistas.usp.br/eav/article/view/8601/10152 Acesso em: 22 mar. 2016.

CHARTIER, Roger. A história cultural: entre práticas e representações. $2^{\mathrm{a}}$ ed. Lisboa: Difel, 2002.

CIAMPI, Helenice. O trabalho das fontes no cotidiano escolar. São Paulo: Revista Histórica do Arquivo do Estado de São Paulo. n. 11. jun/jul/ago, 2003. p. 4-8.

CLAVAL, Paul. A paisagem dos geógrafos. In: CORREAA, Roberto Lobato; ROSENDAHL, Zeny (org.) Paisagens, textos e identidades. Rio de Janeiro: EdUERJ, 2004. p. 13-74.

CORREA, Crishna Mirella de Andrade. O olhar do fotógrafo e o estudo das subjetividades na produção da imagem. In: PELEGRINI, Sandra de Cássia Araújo; ZANIRATO, Sílvia Helena (org.) As dimensões da imagem: abordagens teóricas e metodológicas. Maringá: Eduem, 2005. p. 53-62.

COSGROVE, Denis. A geografia está em toda parte: cultura e simbolismo nas paisagens humanas. In: CORRÊA, Roberto Lobato; ROSENDAHL, Zeny (org.) Paisagem, tempo e cultura. $2^{\mathrm{a}}$ ed. Rio de Janeiro: EdUERJ, 2004. p. 92-123.

COSTA, Emília Viotti da. Da Monarquia à República: momentos decisivos. 9a ed. São Paulo: Editora UNESP, 2010.

CUSTÓDIO, Vanderli. Inundações e escassez de água na região metropolitana de São Paulo. São Paulo: FAPESP; Humanitas, 2012.

DIAS, Gabriel; ALBUQUERQUE, Alex. Muros de reservatório. In Revista Polytechnica, São Paulo, 1905. p. 148. Disponível no sítio: memória.poli.usp.br

DOLLFUS, Olivier. O espaço geográfico. 4 4a edição. São Paulo: Difel, 1982. 
FABRIS, Annateresa (org.) Fotografia: usos e funções no século XIX. São Paulo: Edusp, 1991.

FERREIRA, Graça Maria Lemos; MARTINELLI, Marcello. Geografia em mapas: Brasil - estados e regiões. São Paulo: Moderna, 2000.

FIGUEIREDO, Lauro César. Memória, cidade e documentação: transformação da paisagem cultural da cidade de Santa Maria a partir da fotografia. In: PIMENTA, Margareth de Castro Afeche; FIGUEIREDO, Lauro César. (org.) Lugares: patrimônio, memória e paisagens. Florianópolis: Editora UFSC, 2014. p. 93-130.

FIGUEIRÔA, Silvia F.M. As ciências geológicas no Brasil: uma história social e institucional, 1875 - 1934. São Paulo: Hucitec, 1997.

FIGUEIRÔA, Silvia F.M. 'Batedores da ciência' em território paulista: expedições de exploração e a ocupação do 'sertão' de São Paulo na transição para o século XX. Revista História, Ciências, Saúde - Manguinhos, Rio de Janeiro, v.15, n.3, p.763-777, jul - set, 2008.

Disponível em: $\quad<$ http://www.scielo.br/scielo.php?script=sci arttext\&pid=S010459702008000300010>. Acesso em: 20 out. 2016.

FRANÇA, Ary. O quadro climato-botânico. In: AZEVEDO, Aroldo de (org.) A cidade de São Paulo: estudos de geografia urbana. São Paulo: Companhia Editora Nacional, 1958. v. 1: A região de São Paulo. p. 69-111.

FREITAS, Maria Luíza de. Modernidade concreta: as grandes construtoras e o concreto armado no Brasil, 1920 a 1940. Tese de Doutorado. São Paulo. Faculdade de Arquitetura e Urbanismo da Universidade de São Paulo, 2011.

FUNDAÇÃO ENERGIA E SANEAMENTO. Arquivo virtual disponível em: http://www.energiaesaneamento.org.br/. Acesso em: 5 fev. 2016.

FUNDAÇÃO ENERGIA E SANEAMENTO. Guia da documentação arquivística. São Paulo, 2014.

FURTADO. Celso. Formação econômica do Brasil. $34^{\text {a }}$ ed. São Paulo: Companhia das Letras, 2007.

GANDY, Matthew. Paisagem, estéticas e ideologia. In: CORRÊA, Roberto Lobato; ROSENDAHL, Zeny (org.) Paisagens, textos e identidades. Rio de Janeiro: EdUERJ, 2004. p. 75-90.

GINZBURG, Carlo. Anomalías conjuntivas: uma reflexión sobre los hombres lobo. Disponível em: http://www.scielo.org.co/scielo.php?script=sci arttext\&pid=S0123885X2017000200110, 2017. Acesso em 12 dez. 2017.

GOLDEMBERG, José (coord.) USP 80 anos. São Paulo: Edusp, 2015. 
GOMBRICH, E.H. Arte e ilusão: um estudo da psicologia da representação pictórica. São Paulo: Martins Fontes, 1986.

GREMIO POLYTECHNICO. As obras da "Light" em Santo Amaro. Revista Polytechnica. São Paulo, v.4, n. 21, p. 135-142, abr./maio 1908.

HOBSBAWM, Eric J. A era dos Impérios, 1875-1914. 10ª Ed., Rio de Janeiro: Paz e Terra, 1998.

HOLZER, Werther. Paisagem, imaginário, identidade: alternativas para o estudo geográfico. In: ROSENDAHL, Zeny ; CORREAA, Roberto Lobato (org.) Manifestações da cultura no espaço. Rio de Janeiro: EdUERJ, 1999. p. 149-168.

INSTITUTO MOREIRA SALLES. Sítio: https://ims.com.br/acervos/fotografia/ Acesso em: 19 abr. 2018.

JOLY, Martine. Introdução à análise da imagem. 10 ed. Campinas: Papirus, 2006.

JORGE, Janes. Rios e várzeas na urbanização de São Paulo. São Paulo: Revista Histórica do Arquivo do Estado de São Paulo. n. 11. jun-jul-ago, 2003. p. 9-15.

JORGE, Janes. Rios e saúde na cidade de São Paulo, 1890 - 1940. Uberlândia/MG: Revista História e Perspectiva, jul-dez, 2012. p. 103-124.

JORGE, Janes. Guarapiranga: de represa combatida a patrimônio ambiental, 1906-2006. In: JORGE, Janes (org.) Cidades Paulistas: estudos de história ambiental urbana. São Paulo: Alameda, 2015. p. 209 - 238.

KOSSOY, Boris. Realidades e ficções na trama fotográfica. $3^{\text {a }}$ ed., Cotia: Ateliê Editorial, 2002.

KOSSOY, Boris. Fotografia e história. 5ª ed., São Paulo: Ateliê Editorial, 2014.

KOSSOY, Boris. Os tempos da fotografia: o efêmero e o perpétuo. $3^{\text {a }}$ ed., São Paulo: Ateliê Editorial, 2014a.

LAMOUNIER, Maria Lúcia. Ferrovias e mercado de trabalho no Brasil do século XIX. São Paulo: Edusp, 2012.

LOMBARDO, Magda Adelaide. A relação entre as ilhas de calor e as áreas verdes urbanas: subsídios para o planejamento urbano. Matingá/PR: UEM, 2006.

LOVE, Joseph. A locomotiva: São Paulo na Federação brasileira 1889 - 1937. Rio de Janeiro: Paz e Terra, 1982.

MAGALHÃES, Gildo. Força e luz: eletricidade e modernização na República Velha. São Paulo: Editora UNESP: FAPESP, 2000. 
MANGUEL, Alberto. Lendo imagens: uma história de amor e ódio. São Paulo: Companhia das Letras, 2006.

MARANHÃO, Ricardo; MATEOS, Simone Biehler (org.) 100 anos de história e energia. São Paulo: Andreato Comunicação e Cultura, 2012.

MARTINS, Ana Luiza. Império do café: a grande lavoura no Brasil, 1850 a 1890. 9 ed., São Paulo: Atual, 1995.

MATOS, Odilon Nogueira de. Café e ferrovias: a evolução ferroviária de São Paulo e o desenvolvimento da cultura cafeeira. $4^{\text {a }}$ ed., Campinas: Pontes, 1990.

MATTOS, Dirceu Lino de. O parque industrial paulistano. In: AZEVEDO, Aroldo de (org.) A cidade de São Paulo: estudos de geografia urbana. São Paulo: Companhia Editora Nacional, 1958. v. 3: Aspectos da metrópole paulista. p. 5-98.

MELLO, Flavio Miguez de (coord.) A história das barragens no Brasil, séculos XIX, XX e XXI: cinquenta anos do Comitê Brasileiro de Barragens. Rio de Janeiro: CBDB, 2011.

MENDES, Luciana Cavalcanti. Diários fotográficos de bicicleta em Pernambuco: os irmãos Ulysses e Gilberto Freyre na documentação de cidades na década de 1920. 2016. Dissertação (Mestrado em Culturas e Identidades Brasileiras). São Paulo. Instituto de Estudo Brasileiros, Universidade de São Paulo.

MENDES, Renato da Silveira. Os bairros da zona sul e os bairros ocidentais. In: AZEVEDO, Aroldo de (Org.) A cidade de São Paulo: estudos de geografia urbana. São Paulo: Companhia Editora Nacional, 1958. v. 3: Aspectos da metrópole paulista. p. 257-364.

MENESES, Ulpiano T. Bezerra de. A paisagem como fato cultural. In: YÁZIGI, Eduardo (org.) Turismo e paisagem. São Paulo: Contexto, 2002. p. 29-64.

MILLIET, Sérgio. Roteiro do café e outros ensaios. 4ª ed., São Paulo: Hucitec, 1982.

MONBEIG, Pierre. Novos estudos de geografia humana brasileira. São Paulo: Difusão Europeia do Livro, 1957.

MONBEIG, Pierre. Pioneiros e fazendeiros de São Paulo. São Paulo: Hucitec/Polis, 1984.

MONDENARD, Anne de. A emergência de um novo olhar sobre a cidade: as fotografias urbanas de 1870 a 1918. 1999. Disponível em: https://revistas.pucsp.br/index.php/revph/article/view/10981. Acesso em: 5 dez. 2017.

MORAES, José Geraldo Vinci de. Cidade e cultura urbana na Primeira República. $2^{a}$ ed., São Paulo: Atual, 1994. 
MORSE, Richard M. Formação histórica de São Paulo. São Paulo: Difusão Europeia do Livro, 1970.

PAIVA, Eduardo França. História e imagens. $2^{a}$ ed., Belo Horizonte: Autêntica, 2004.

PATACA, Ermelinda Moutinho. Mobilidades e permanências de viajantes no Mundo Português: entre práticas e representações científicas e artísticas. Cap. 2. Tese de Livre-Docência. São Paulo. Faculdade de Educação da Universidade de São Paulo, 2015.

PATACA, Ermelinda Moutinho. História e filosofia da química: química, mineração e metalurgia no período colonial brasileiro. São Paulo: Univesp, Aula 5. 6 dez. 2017. Disponível em: https://www.youtube.com/watch?v=BNJJg0rP92w Acesso em: 23 abr. 2018.

PERALTA, Inez Garbuio. Santo Amaro: um século de autonomia. 2a ed., São Paulo: Companygraf, 2017.

PEREIRA, Adriana Martins. Lentes da memória: a descoberta da fotografia de Alberto de Sampaio, 1888-1930. Rio de Janeiro: Bazar do Tempo, 2016.

PERISSINOTO, Renato. Classes dominantes e hegemonia na República Velha. Campinas: Ed. Unicamp, 1994.

PONTES, José Alfredo Vidigal e MESQUITA FILHO, Ruy. São Paulo de Piratininga: de pouso de tropas a metrópole. São Paulo: O Estado de S.Paulo: Editora Terceiro Nome, 2003.

PRADO JÚNIOR, Caio. História econômica do Brasil. 23a ed., São Paulo: Brasiliense, 1980.

RADESCA, Maria de Lourdes P. Souza. O problema da energia elétrica. In: AZEVEDO, Aroldo de (Org.) A cidade de São Paulo: estudos de geografia urbana. São Paulo: Companhia Editora Nacional, 1958. v. 3: Aspectos da metrópole paulista. p. 99-120.

RAMOS, Francisco Ferreira. A electricidade e a hulha branca em S.Paulo. Revista Polytechnica, São Paulo, v. 2, n. 9, p. 107-111, dez. 1905.

REIS FILHO, Nestor Goulart. Dois séculos de projetos no Estado de São Paulo. São Paulo: Edusp; Imprensa Oficial, 2010. v. 2: Grandes obras e urbanização, 1889 - 1930.

RICARDI, Alexandre. A Companhia Água e Luz do Estado de São Paulo e suas relações de conflito na formação do parque elétrico paulistano, 1890-1910. 2013. Dissertação (Mestrado em História Social). São Paulo. Faculdade de Filosofia, Letras e Ciências Humanas, Universidade de São Paulo.

ROLNIK, Raquel. São Paulo, início da industrialização: o espaço e a política. In: KOWARICK, Lúcio (org.): As lutas sociais e a cidade: São Paulo passado e presente. Rio de Janeiro: Paz e Terra, 1988. p. 75-94. 
ROLNIK, Raquel. A cidade e a lei: legislação, política urbana e território na cidade de São Paulo. $3^{\text {a }}$ ed. São Paulo: Studio Nobel, 2003.

SABESP, Companhia de Saneamento Básico do Estado de São Paulo. Dossiê: Sistema Guarapiranga. São Paulo: Sabesp, 2008.

SAES, Flávio Azevedo Marques de. A grande empresa de serviços na economia cafeeira 1850 - 1930. São Paulo: Hucitec, 1986.

SAES, Flávio. São Paulo republicana: vida econômica. In: PORTA, Paula (org.). História da cidade de São Paulo: a cidade na primeira metade do século XX, 18901954. São Paulo: Paz e Terra, 2004. v. 3. p. 214-257.

SANTAELLA, Lucia; NÖTH, Winfried. Imagem: cognição, semiótica, mídia. São Paulo: Iluminuras, 2008.

SANTOS, Elina de Oliveira. Tietê, o rio de São Paulo. In: AZEVEDO, Aroldo de (org.) A cidade de São Paulo: estudos de geografia urbana. São Paulo: Companhia Editora Nacional, 1958. v. 1: A região de São Paulo. p. 46-67.

SANTOS, Milton. Sociedade e espaço: a formação social como teoria e como método. Boletim Paulista de Geografia, no. 54, julho de 1977. São Paulo: AGB, p. 81-99. Disponível em: $\quad<$ http://miltonsantos.com.br/mwginternal/de5fs23hu73ds/progress?id=eoRIkiMb60a9hmtEo6d9J2_oaH41VayW9bXpNC KKDfc > Acesso em: 6 jun. 2016.

SANTOS, Milton. A natureza do espaço: técnica e tempo, razão e emoção. São Paulo: Edusp, 2002.

SANTOS, Milton. Por uma outra globalização: do pensamento único à consciência universal. 11 $1^{\mathrm{a}}$ ed., Rio de Janeiro: Record, 2004.

SANTOS, Milton. A urbanização brasileira. 5a ed., São Paulo: Edusp, 2005.

SANTOS, Milton. Técnica, espaço, tempo: globalização e meio técnico-científicoinformacional. $5^{\text {a }}$ ed., São Paulo: Edusp, 2013.

SANTOS, Milton. Espaço e método. 5a ed., São Paulo: Edusp, 2014.

SAUER, Carl O. A morfologia da paisagem. In: CORRÊA, Roberto Lobato; ROSENDAHL, Zeny (org.) Paisagem, tempo e cultura. $2^{\mathrm{a}}$ ed. Rio de Janeiro: EdUERJ, 2004. p. 12-74.

SÁVIO, Marco A.C. A Light \& Power e a construção do momentum da eletricidade em São Paulo. Marechal Cândido Rondon/PR: Revista Tempos Históricos - Unioeste, v. 7, p. 187-214, 2005. 
SÁVIO, Marco A.C. Lembranças da Cachoeira do Inferno: as águas, a energia e a represa de Parnahyba (1899-1901). In: JORGE, Janes (org.) Cidades Paulistas: estudos de história ambiental urbana. São Paulo: Alameda, 2015. p. 119-135.

SÁVIO, Marco A.C. Divulgação científica, imagem e modernização: o papel da revista Politécnica na definição das instituições de ciência em São Paulo. Revista ArtCultura, Instituto de História da Universidade Federal de Uberlândia. v. 18, n. 32, p. 55-71, jan-jun, 2016.

SCHERER, Rebeca. Paisagem urbanística, urbanização pós-moderna e turismo. In: YÁZIGI, Eduardo (org.) Turismo e paisagem. São Paulo: Contexto, 2002. p. 83-105.

SCHWARCZ, Lilia Moritz. Lendo e agenciando imagens: o rei, a natureza e seus belos naturais. Rio de Janeiro: Sociologia \& Antropologia. v.04, n.02. p. 391-431, out., 2014. Disponível em: http://revistappgsa.ifcs.ufrj.br/wp-content/uploads/2015/05/5ano4-v04n02_lilia-moritz-schwarcz.pdf

SEGAWA, Hugo. São Paulo, veios e fluxos: 1872-1954. In: PORTA, Paula (org.). História da cidade de São Paulo. São Paulo: Paz e Terra, 2004. v.3: A cidade na primeira metade do século XX, 1890-1954. p. 340-385.

SEVCENKO, Nicolau. Orfeu extático na metrópole: São Paulo, sociedade e cultura nos frementes anos 20. São Paulo: Companhia das Letras, 1992.

SEVCENKO, Nicolau. Introdução. O prelúdio republicano, astúcias da ordem e ilusões do progresso. In: SEVCENKO, Nicolau (org.). História da vida privada no Brasil. São Paulo: Companhia das Letras, 1998. v. 3: República: da Belle Époque à Era do Rádio. p. 7-48.

SEVERINO, Antônio Joaquim. Metodologia do trabalho científico. 23 ${ }^{\mathrm{a}}$ ed., São Paulo: Cortez, 2007.

SILVA, João Luiz Máximo da. Cozinha Modelo: o impacto do gás e da eletricidade na casa paulistana (1870-1930). São Paulo: Edusp, 2008.

SIQUEIRA, Rogério Monteiro de. A matemática e seus usos controlados: engenheiros matemáticos positivistas do Brasil Imperial ao Republicano. Tese de LivreDocência. São Paulo. Escola de Artes, Ciências e Humanidades da Universidade de São Paulo, 2017.

SOUZA, Edgard de. História da Light: primeiros 50 anos. São Paulo: ELETROPAULO, 1982.

TOLEDO, Roberto Pompeu de. A capital da vertigem: uma história de São Paulo de 1900 a 1954. Rio de Janeiro: Objetiva, 2015.

TURAZZI, Maria Inez. As artes do ofício: fotografia e memória da engenharia no século XIX. Tese de Doutorado. São Paulo. Faculdade de Arquitetura e Urbanismo da Universidade de São Paulo, 1997. 
TURAZZI, Maria Inez. Paisagem construída: fotografia e memória dos "melhoramentos urbanos" na cidade do Rio de Janeiro. Belo Horizonte: Varia História. v. 22, n. $35 . \quad$ p. 64-78, jan/jun., 2006. Disponível em: http://www.scielo.br/scielo.php?script=sci arttext\&pid=S0104-87752006000100005.

Acesso em: 3 abr. 2018.

VIDIGAL, José Alfredo; MESQUITA FILHO, Ruy. São Paulo de Piratininga: de pouso de tropas a metrópole. São Paulo: O Estado de S.Paulo; Editora Terceiro Nome, 2003.

WENDEL, Guilherme. As forças hydraulicas do Estado de S.Paulo. Revista Polytechnica, São Paulo, v. 3, n. 15, p. 140-146, maio 1907.

WHATELY, Marussia e CUNHA, Pilar Machado da. Guarapiranga 2005: como e porque São Paulo está perdendo este manancial - resultados do diagnóstico socioambiental participativo da Bacia Hidrográfica da Guarapiranga. São Paulo: Instituto Socioambiental, 2006.

ZANIRATO, Sílvia Helena. A fotografia de imprensa: modos de ler. In: PELEGRINI, Sandra de Cássia Araújo; ZANIRATO, Sílvia Helena (org.) As dimensões da imagem: abordagens teóricas e metodológicas. Maringá: Eduem, 2005. p. 15-37.

ZANIRATO, Silvia Helena. O lugar da paisagem cultural no patrimônio. In: PIMENTA, Margareth de Castro Afeche; FIGUEIREDO, Lauro César. (org.) Lugares: patrimônio, memória e paisagens. Florianópolis: Editora UFSC, 2014. p. 293-316. 